\title{
Flora da Bahia: Turneraceae
}

\section{Lamarck Rocha* \& Alessandro Rapini ${ }^{\mathrm{a}}$}

Programa de Pós-graduação em Botânica, Departamento de Ciências Biológicas, Universidade Estadual de Feira de Santana, Feira de Santana, Bahia, Brasil.

Resumo - É apresentado o levantamento florístico das Turneraceae do estado da Bahia, Brasil. São reconhecidos dois gêneros e 63 espécies: Piriqueta, com 23 espécies, e Turnera, com 40. São apresentadas chaves de identificação, descrições, ilustrações, comentários gerais e mapas de distribuição dos táxons na Bahia.

Palavras-chave adicionais: florística, Piriqueta, Região Nordeste, taxonomia, Turnera.

\begin{abstract}
Flora of Bahia: Turneraceae) - A floristic account of the Turneraceae from Bahia State, Brazil, is presented. Two genera and 63 species are recognized: Piriqueta with 23 species and Turnera with 40. Identification keys, descriptions, illustrations, general notes and species distribution maps in Bahia are provided.
\end{abstract}

Additional key words: floristics, Northeast Brazil, Piriqueta, taxonomy, Turnera.

\section{TURNERACEAE}

Ervas anuais ou perenes, subarbustos ou arbustos. Folhas pecioladas, alternas, papiráceas a coriáceas, simples, geralmente pilosas, nervação broquidódroma, margens inteiras, serreadas a crenadas; frequentemente 1 a vários pares de nectários extraflorais opostos ou alternos, peciolares a basilaminares, circulares ou elípticos; estípulas rudimentares ou desenvolvidas, às vezes ausentes. Inflorescências uni a multifloras, axilares ou terminais, cimosas ou racemosas; pedúnculo livre ou adnato ao pecíolo (flor epífila); brácteas presentes ou não; bractéolas (profilos) 2, alternas ou opostas, às vezes rudimentares; pedicelo ausente ou desenvolvido. Flores bissexuadas, actinomorfas, hipóginas, frequentemente heterostilas. Cálice 5-laciniado, 10-nervado, 1/3 proximal gamossépalo, prefloração quincuncial. Pétalas 5, livres, alternissépalas, unguiculadas, prefloração contorta, unha soldada ao tubo do cálice, formando um tubo floral. Corona presente ou não. Estames 5; filetes cilíndricos ou achatados dorsiventralmente, alternipétalos, livres entre si, base discretamente adnata ao tubo floral, às vezes com margens adnatas à unha das pétalas, formando sacos nectaríferos; anteras bitecas, dorsifixas ou basifixas, deiscência longitudinal, introrsa. Grãos de pólen 3-colporados, subprolatos a prolato-esferoidais. Ovário súpero, 3carpelar, gamocarpelar, unilocular; placentação parietal, óvulos 3 a muitos, anátropos; estiletes 3, cilíndricos, estigmas geralmente penicelados. Frutos cápsulas loculicidas, 3-valvares. Sementes geralmente reticuladas; arilo carnoso quando vivo, membranáceo quando seco; embrião cilíndrico.

\footnotetext{
*Autor para correspondência: lamarck_rocha@hotmail.com;

arapinibot@yahoo.com.br

Editor responsável: Pedro Fiaschi

Submetido: 19 jan. 2015; aceito: 4 dez. 2015

Publicação eletrônica: 28 dez. 2015; versão final: 18 ian. 2016
}

Inclui 12 gêneros e 229 espécies, distribuídas nas áreas tropicais e subtropicais das Américas, e no continente Africano, em Madagascar e nas Ilhas Mascarenhas. A diversidade genérica é maior na África, onde ocorrem nove gêneros (Arbo 2007; Thulin et al. 2012). Nas Américas, são registrados quatro gêneros: Adenoa Arbo, Erblichia Seem., Piriqueta Aubl. e Turnera L. No Brasil, ocorrem apenas Piriqueta e Turnera, totalizando 158 espécies; destas, 112 são endêmicas (Rocha et al. 2014; Arbo 2015). O centro de diversidade específica da família está localizado na Cadeia do Espinhaço, nos estados da Bahia e Minas Gerais (Arbo \& Mazza 2011). No estado da Bahia, foram encontradas 23 espécies de Piriqueta e 40 de Turnera.

\section{Chave para os gêneros}

1. Flores com corona membranácea, fimbriada, localizada na unha das pétalas e sobre as sépalas. Indumento com tricomas tectores estreladoporrectos ............................................. 1. Piriqueta

1'. Flores sem corona, raro com apêndice ou lígula apenas na unha das pétalas. Indumento sem tricomas tectores estrelado-porrectos .... 2. Turnera

\section{Piriqueta Aubl.}

Arbustos, subarbustos ou ervas. Estípulas 2, reduzidas ou ausentes. Folhas papiráceas a coriáceas; nectários extraflorais geralmente ausentes. Inflorescências axilares; cimosas, em cincinos bi a multifloros, ou unifloras, solitárias, raro agrupadas em racemo terminal; pedúnculo desenvolvido, livre do pecíolo; brácteas ausentes; bractéolas 2, desenvolvidas ou rudimentares, reduzidas a um tufo de tricomas ou ausentes, alternas, localizadas próximo à articulação do pedúnculo com o pedicelo. Flores heterostilas, raro homostilas; pedicelo desenvolvido, mais largo e escuro do que o pedúnculo. Cálice campanulado; lacínios triangulares a estreitotriangulares, ápice agudo a mucronado. Corola 
amarela, em diferentes tonalidades de rosa, raro branca, laranja ou vermelha. Corona membranácea, fimbriada, na unha das pétalas e sobre as sépalas. Filetes com base discretamente adnata ao tubo floral; anteras ovoides ou sagitadas, dorsifixas. Ovário ovoide, piloso; estiletes glabros ou pilosos. Cápsulas globosas a ovoides; epicarpo liso, tuberculado ou verrucoso. Sementes retas ou curvas, reticuladas; aréolas do retículo côncavas, com até 2 depressões puntiformes; calaza arredondada, obtusa ou ligeiramente proeminente, superfície plana a côncava; arilo lobulado, lacerado, por vezes inteiro, igual ou menor que a semente.

O gênero Piriqueta inclui 46 espécies distribuídas do sul dos Estados Unidos à Argentina, compondo um grupo monofilético bem sustentado (Arbo 2007; Thulin et al. 2012; Rocha et al. 2014). No Brasil são registradas 39 espécies, cujo centro de diversidade está localizado na região da Chapada Diamantina, na Bahia (Arbo \& Mazza 2011; Arbo 2015). Na Bahia, foram registradas 23 espécies, principalmente em cerrados, campos rupestres e caatingas.

\section{Chave para as espécies}

1. Inflorescências em cincinos bi a multifloros, às vezes as dos nós inferiores unifloras.

2. Corola laranja, laranja-avermelhada ou vermelha, mesmo quando seca.

3. Folhas recurvadas; face adaxial glabra ou com tricomas esparsos, face abaxial com tricomas concentrados nas nervuras

3'. Folhas aplanadas; face adaxial denso-pilosa a tomentosa, face abaxial tomentoso-velutina.

4. Folhas com ápice agudo, margens inteiras a denticuladas; face adaxial não bulada

4'. Folhas com ápice obtuso, margens crenadas; face adaxial bulada

1.1. P. abairana

2'. Corola branca, creme, amarela, em tons de rosa ou salmão.

5. Corola branca. Bractéolas obovadas ou lanceoladas 1.13. P. flammea

5'. Corola creme, amarela ou em tons de rosa ou salmão. Bractéolas linear-triangulares.

6. Tricomas glandulares setiformes ausentes; tricomas tectores estrelados e estrelado-porrectos de base globosa, inchada, perceptíveis a olho nu

1.7. $P$. constellata

6'. Tricomas glandulares setiformes presentes; tricomas tectores estrelados e estrelado-porrectos de base globosa, menores e pouco visíveis.

7. Frutos com epicarpo liso ou tenuamente verrucoso.

8. Tricomas glandulares setiformes de base esbranquiçada, principalmente no caule e epicarpo ...

8'. Tricomas glandulares setiformes de base hialina em toda a planta.

1.11. P. douradinha

9. Cincinos 2-10-floros; pedicelos geralmente curtos, 1,7-4 mm compr. Cálice 4-8 $\mathrm{mm}$ compr. Corola 6-12 mm compr.

1.15. P. nanuzae

9'. Cincinos 1-3-floros; pedicelos geralmente longos, 4-10 mm compr. Cálice 9-12 mm compr. Corola 1,5-1,6 cm compr.

1.8. P. crenata

7'. Frutos com epicarpo granuloso ou tuberculado.

10. Caules denso- a esparso-escabrosos

1.2. P. asperifolia

10'. Caules tomentosos, tomentoso-hirsutos a velutinos.

11. Corola rosa a salmão

1.10. P. dentata

11'. Corola creme, amarela ou amarelo-alaranjada.

12. Folhas concolores, base atenuada a cuneado-atenuada

1.22. P. sulfurea

12'. Folhas discolores, base cuneada, arredondada ou cordada.

13. Folhas ovadas, estreito-ovadas, elípticas, raro obovadas; face adaxial esparso a denso-pilosa

1.21. P. sidifolia

13'. Folhas estreito-oblongas, estreito-elípticas a lineares; face adaxial tomentosa, às vezes velutina

1.9. P. densiflora

1'. Inflorescências unifloras, às vezes agrupadas em racemo terminal.

14. Frutos com epicarpo liso.

15. Flores solitárias. Sementes retas ou ligeiramente curvas; nós do retículo não proeminentes

1.6. $P$. cistoides

15'. Flores agrupadas em racemos terminais. Sementes fortemente curvas; nós do retículo proeminentes .. . racemosa

14'. Frutos com epicarpo granuloso ou tuberculado.

16. Corola creme, amarela ou amarelo-alaranjada (excepcionalmente creme-rosada em P. breviseminata, mas então sementes largo-obovoides).

17. Folhas com margens inteiras ou discretamente serrilhadas; face adaxial apenas com a nervura principal impressa. 
18. Lâmina foliar 4,5-11 mm compr., coriáceas, margens fortemente revolutas. Bractéolas $0,5-2 \mathrm{~mm}$ compr. 1.18. $P$. revoluta

18'. Lâmina foliar 20-50 mm compr., cartáceas, margens planas. Bractéolas ausentes . 1.16. P. plicata

17'. Folhas com margens recortadas (excepcionalmente inteiras nas folhas apicais de $P$. scabrida); face adaxial com nervuras impressas.

19. Corola creme a creme-rosada. Sementes largo-obovoides 1.4. P. breviseminata

19'. Corola alaranjada ou amarelo-alaranjada. Sementes oblongo-cilíndricas, obovoides, estreito-obovoides a clavadas.

20. Folhas aplanadas, base arredondada. Tricomas glandulares setiformes ausentes. Flores heterostilas 1.20. P. scabrida

20'. Folhas recurvadas, base atenuada. Tricomas glandulares setiformes presentes. Flores homostilas 1.23. P. viscosa

16'. Corola em diferentes tons de rosa ou salmão. Sementes nunca largo-obovoides.

21. Bractéolas 0,5-2 mm compr., linear-triangulares. Epicarpo com tricomas estrelados e estreladoporrectos 1.10. P. dentata

21'. Bractéolas rudimentares ou reduzidas a um tufo de tricomas (excepcionalmente ca. $3 \mathrm{~mm}$ compr. em $P$. duarteana). Epicarpo com tricomas glandulares setiformes.

22. Flores homostilas. Corola pequena, 6-7 mm compr.

1.23. P. viscosa

22 '. Flores heterostilas. Corola geralmente grande, $10-25 \mathrm{~mm}$ compr.

23. Estigmas pseudocapitados; base foliar arredondada ou cordada

1.5. P. carnea

23'. Estigmas penicelados; base foliar atenuada, cuneada ou arredondada.

24. Pedúnculos florais geralmente curtos, 2-8(-15) $\mathrm{mm}$ compr. Epicarpo com tricomas glandulares setiformes de base castanho-escura ..... 1.12.P. duarteana

24'. Pedúnculos florais geralmente longos, (4-)7-20 mm compr. Epicarpo com tricomas glandulares setiformes de base hialina 1.14. P. guianensis

1.1. Piriqueta abairana Arbo, Kew Bull. 54(2): 459. 1999.

Figuras 1A e 16; Arbo (1999: fig. 1A-F).

Arbustos $0,4-1,9 \mathrm{~m}$ alt.; caules tomentosos, tricomas tectores simples e estrelado-porrectos ferrugíneos e raros glandulares setiformes. Estípulas rudimentares. Folhas com pecíolo $1-2 \mathrm{~mm}$ compr.; lâmina $1-2,5(-6,5) \times 0,3-2 \mathrm{~cm}$, coriácea, discolor, aplanada, ovado-elíptica a lanceolada, base arredondada ou subcordada, ápice agudo, margens inteiras a denticuladas, revolutas; face adaxial tomentosa, não bulada, nervuras impressas, face abaxial tomentoso-velutina, nervuras proeminentes. Inflorescências em cincinos (1)2-floros, axilares; pedúnculo 3,5-12 $\mathrm{mm}$ compr.; bractéolas $1-3 \mathrm{~mm}$ compr., linear-triangulares. Flores heterostilas; pedicelo 2-5 $\mathrm{mm}$ compr. Cálice $7-11 \mathrm{~mm}$ compr., externamente tomentoso, castanho-escuro. Corola 1,3-2 cm compr., laranja a laranja-avermelhada. Filetes 6-7,5 $\mathrm{mm}$ compr. em flores brevistilas, 4-6 $\mathrm{mm}$ compr. em flores longistilas, glabros; anteras 1,5-2,5 mm compr. Ovário 1,7-2,5 mm compr.; estiletes 1,8-2 mm compr. em flores brevistilas, 4-6 $\mathrm{mm}$ compr. em flores longistilas, glabros; estigmas penicelados. Cápsulas 6-8 $\mathrm{mm}$ diâm.; epicarpo tenuamente verrucoso, esparso-hirsuto. Sementes 2,5-3 $\times$ ca. $1 \mathrm{~mm}$, obovoides, ligeiramente curvas; epiderme papilosa.

Rara, endêmica da porção sul da Chapada Diamantina, na Bahia (Arbo 1995; Arbo \& Giulietti 2009). F6: campos rupestres, campos gerais e carrascais.
Cresce em afloramentos de rocha granítica, substratos arenosos, ou brejo, em altitudes de 1000-1700 m. Apresenta flores e frutos de dezembro a julho.

Material selecionado - Abaíra, Boa Vista, acima do Capão do Mel, 13ำ'S, 41 ${ }^{\circ} 50^{\prime} \mathrm{W}, 1250$ m, 11 jun. 1994 (fl., fr.), W. Ganev 3344 (holótipo HUEFS, isótipos CTES, SPF); ib., Bicota, alto da

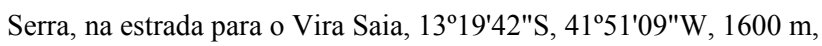
12 dez. 2009 (fl., fr.), D. Cardoso et al. 2829 (CTES, HUEFS); Mucugê, estrada atrás das estufas de flores, em direção à Serra, $13^{\circ} 01^{\prime} \mathrm{S}, 41^{\circ} 44^{\prime} \mathrm{W}, 1027 \mathrm{~m}, 21$ jul. 2010 (fl.), N. Roque 2885

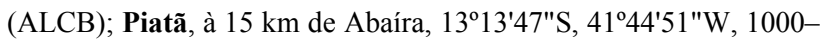
1100 m, 25 fev. 1994 (fl., fr.), P.T. Sano et al. CFCR 14549 (SPF); Rio de Contas, Arapiranga, Gerais do Porco Gordo, $13^{\circ} 28^{\prime} \mathrm{S}$, 414' 'W, 22 jul. 2007 (fl., fr.), C. van den Berg 1894 (HUEFS).

Pode ser reconhecida pelo cálice castanho-escuro e corola laranja-avermelhada, cor rara em Piriqueta, além das folhas geralmente ovadas a ovado-elípticas, com margens inteiras a denticuladas, face adaxial ferrugínea a verde-oliva e face abaxial ferrugíneopálida. Devido à cor da corola, $P$. abairana se assemelha a $P$. flammea e $P$. sarae; a primeira se diferencia pelas folhas com margens crenadas e face adaxial bulada, castanho-escura; a segunda se diferencia pelas folhas com margens crenadas e face adaxial bulada, lustrosa e esparso-pilosa.

\subsection{Piriqueta asperifolia Arbo, F1. Neotrop. Monogr.} 67: 46. 1995.

Figuras 16; Arbo (1995: fig. 25E-J).

Subarbustos a arbustos 0,3-2 m alt.; caules densoa esparso-escabrosos, tricomas tectores simples, 
estrelados, estrelado-porrectos e raros glandulares setiformes, dourados. Estípulas até ca. 0,5 mm compr. Folhas com pecíolo 1-10 mm compr.; lâmina 2-7($9,4) \times(0,3-) 0,9-2 \mathrm{~cm}$, cartácea ou coriácea, discolor, recurvada, estreito-elíptica a estreito-oblonga, raro linear, base cuneada a arredondada, ápice agudo a obtuso, margens crenadas, revolutas; face adaxial escabrosa, bulada, nervuras fortemente impressas, face abaxial tomentosa, nervuras proeminentes. Inflorescências em cincinos 2-11-floros, axilares; pedúnculo 7-35 mm compr.; bractéolas 1-2,5 $\mathrm{mm}$ compr., linear-triangulares. Flores heterostilas; pedicelo 2-7 $\mathrm{mm}$ compr. Cálice (4-)7-10 $\mathrm{mm}$ compr., externamente tomentoso, dourado-ferrugíneo. Corola (7-)8,5-12 mm compr., amarela. Filetes ca. 4 $\mathrm{mm}$ compr. em flores brevistilas, 2-3,3 $\mathrm{mm}$ compr. em flores longistilas, glabros; anteras 1,3-3 mm compr. Ovário 1-2 mm compr.; estiletes $1-1,5 \mathrm{~mm}$ compr. em flores brevistilas, $2,5-4 \mathrm{~mm}$ compr. em flores longistilas, glabros; estigmas penicelados. Cápsulas 5-7 mm diâm.; epicarpo granuloso, esparso-estrigoso. Sementes 2,3-3 × 0,7-1 mm, obovoides, ligeiramente curvas; epiderme papilosa.

Rara, endêmica da porção norte da Chapada Diamantina, na Bahia (Arbo 1995; Arbo \& Giulietti 2009). C6, D6, D7, E6: cerrados, campos rupestres, caatingas, carrascos e campos gerais. Habita áreas abertas, sobre afloramentos rochosos quartzíticos, em substratos arenosos ou argilosos, em altitudes de 500 $1200 \mathrm{~m}$. Apresenta flores e frutos nos meses de novembro a julho.

Material selecionado - Jacobina, Morro da Torre, próximo ao cruzeiro, $11^{\circ} 12^{\prime} 13^{\prime \prime S}, 40^{\circ} 30^{\prime} 27^{\prime \prime} \mathrm{W}, 800-1000 \mathrm{~m}, 30 \mathrm{dez} .2004$ (fl., fr.), R. Mello-Silva \& R.C. Forzza 2814 (CTES, RB, SPF); Morro do Chapéu, ca. $16 \mathrm{~km} \mathrm{SW}$ da cidade, na estrada para Utinga, $11^{\circ} 38^{\prime} \mathrm{S}, 41^{\circ} 17^{\prime} \mathrm{W}, 980 \mathrm{~m}, 1$ jun. 1980 (fl., fr.), R.M. Harley et al. 22941 (holótipo CTES, isótipos CEPEC, E-foto, Kfoto, NY-foto, US-foto); ib., $16 \mathrm{~km} \mathrm{SW}$ de Morro do Chapéu, estrada para Utinga, $11^{\circ} 38^{\prime} \mathrm{S}, 41^{\circ} 16^{\prime} \mathrm{W}, 1030 \mathrm{~m}, 28$ nov. 1992 (fl., fr.), M.M. Arbo et al. 5361 (CTES, G-foto, HUEFS, K-foto, MBM, MO-foto, NY-foto, SI-foto, RB, SPF); Sento Sé, Riacho da Barra, margens do riacho, $10^{\circ} 25^{\prime} 25^{\prime \prime} \mathrm{S}, 41^{\circ} 32^{\prime} 04^{\prime \prime} \mathrm{W}, 770 \mathrm{~m}, 27$ jan. 2010 (fl., fr.), M. Oliveira 4713 (CTES, HVASF); Umburanas, Delfino, Serra do Curral Frio, $10^{\circ} 20^{\prime} 31$ "S, $41^{\circ} 18^{\prime} 48^{\prime \prime} \mathrm{W}, 1200 \mathrm{~m}$, 28 maio 2010 (fl., fr.), D. Cardoso et al. 2996 (HUEFS); Utinga, estrada para Bonito, $12^{\circ} 02^{\prime} 41^{\prime \prime S}, 41^{\circ} 08^{\prime} 02^{\prime \prime} \mathrm{W}, 27$ jul. 2007 (fl.), E. Melo et al. 5131 (HUEFS).

Pode ser reconhecida principalmente pelo indumento escabroso com tricomas estreladoporrectos com poucos raios, sendo o raio central robusto e rígido. É similar a $P$. densiflora, que se diferencia pelas folhas velutinas, com tricomas estrelado-porrectos multirradiados, de raio central delgado. O exemplar Melo 5131 apresenta folhas lineares com ápice agudo, margens sinuadas, quase inteiras, e flores pequenas, mas exibe o indumento típico da espécie.
1.3. Piriqueta assuruensis Urb., Jahrb. Königl. Bot. Gart. Berlin 2: 60. 1883.

Figuras 17; Arbo (1995: fig. 27E-I).

Subarbustos $0,5-2,5 \mathrm{~m}$ alt.; caules tomentosos, tricomas tectores simples patentes, estrelados, estreladoporrectos e glandulares setiformes, dourados. Estípulas 0,1-1,3 mm compr. Folhas com pecíolo 5-16(-25) mm compr.; lâmina (3-)5,5-8 × 1-4 cm, cartácea, discolor, recurvada, ovada a lanceolada, base arredondada, às vezes cordada ou cuneada, ápice agudo ou obtuso, margens simples ou duplamente crenadas, revolutas; face adaxial pilosa a esparso-pilosa, profundamente bulada, nervuras profundamente impressas, face abaxial densamente tomentoso-velutina, nervuras proeminentes. Inflorescências em cincinos 4-8-floros, axilares; pedúnculo 5-20 $\mathrm{mm}$ compr.; bractéolas $1-7 \mathrm{~mm}$ compr., obovadas ou lanceoladas. Flores heterostilas; pedicelo 5-7 mm compr. Cálice 3-7 mm compr., externamente tomentoso, verde-oliva. Corola 4-8 mm compr., branca, base das pétalas púrpura. Filetes $4-5 \mathrm{~mm}$ compr. em flores brevistilas, 2,5-3 $\mathrm{mm}$ compr. em flores longistilas, glabros; anteras $0,9-1,2 \mathrm{~mm}$ compr. Ovário $1-1,5 \mathrm{~mm}$ compr.; estiletes $0,9-1 \mathrm{~mm}$ compr. em flores brevistilas, 2-3 $\mathrm{mm}$ compr. em flores longistilas, glabros; estigmas brevemente penicelados. Cápsulas 6$8 \mathrm{~mm}$ diâm.; epicarpo granuloso-tuberculado, esparsohirsuto. Sementes 2,4-3 3 1,1-1,5 mm, obovoides, retas; epiderme com papilas filiformes.

Rara, endêmica do norte da Bahia (Arbo 1995; Arbo \& Giulietti 2009). C5, D5: caatingas. Cresce entre as fendas de afloramentos rochosos, em substratos arenosos, aparentemente em áreas abertas, em altitudes de 500-600 m. Apresenta flores e frutos de outubro a junho.

Material selecionado - Barra, dunas do São Francisco, 1047'38"S, 4250'37"W, 408 m, 25 jun. 2009 (fl., fr.), D. Araújo et al. 675 (CTES, HVASF, IPA); Gentio do Ouro, Serra d'Açuruá, sertão do rio São Francisco, aprox. $11^{\circ} 07^{\prime} \mathrm{S}, 42^{\circ} 44^{\prime} \mathrm{W}, 1839$ (fl., fr.), J.S. Blanchet 2822 (lectótipo P-foto, isótipos BM-foto, BR-foto, Ffoto, FI-foto, G-foto, K-foto, NY-foto, P-foto, W-foto); ib., São Inácio, $11^{\circ} 07^{\prime} \mathrm{S}, 42^{\circ} 44^{\prime} \mathrm{W}, 500$ m, 5 out. 1990 (fl.), A. Freire-Fierro et al. 1788 (CTES, SPF).

Pode ser reconhecida pelas flores geralmente pequenas, com corola branca e base das pétalas púrpura, uma característica única nas espécies de Piriqueta com inflorescências em cincinos, além das folhas com face adaxial profundamente bulada e face abaxial ferrugíneo-acinzentada, e sementes com 1 ou 2 depressões puntiformes nas aréolas. Piriqueta assuruensis se assemelha a $P$. sidifolia, a qual pode ser diferenciada pelas bractéolas linear-triangulares e flores de corola maior e amarela. Urban (1883) descreveu esta espécie como homostila; mas, em Arbo (1995) e neste estudo, foram analisadas plantas longistilas e brevistilas, além de algumas com androceu e gineceu de comprimento quase igual, algo que Arbo (1995) chamou de flores mediostilas. 
1.4. Piriqueta breviseminata Arbo, Fl. Neotrop. Monogr. 67: 91. 1995.

Figuras 1B, C e 17; Arbo (1995: fig. 45A-F); Rocha \& Moreira (2014: fotos 1-3).

Subarbustos $0,3-1 \mathrm{~m}$ alt.; caules tomentosos, tricomas tectores estrelados, estrelado-porrectos e glandulares setiformes, dourados ou castanho-escuros. Estípulas até ca. 0,5 mm compr. Folhas com pecíolo 4 $10 \mathrm{~mm}$ compr.; lâmina 3,5-7,3 ×0,3-1,5 cm, papirácea, discolor, recurvada, estreito-elíptica, elíptica, oblanceolada a quase linear, base cuneada, ápice agudo a obtuso, margens serreado-crenadas a serrilhadocrenuladas, planas ou revolutas; face adaxial densopilosa, não bulada, nervuras impressas, face abaxial tomentosa, nervuras proeminentes. Inflorescências unifloras, axilares; pedúnculo 3-14 mm compr.; bractéolas reduzidas a coléteres ou um tufo de tricomas; pedicelo 2-7 mm compr. Flores heterostilas. Cálice 5$10 \mathrm{~mm}$ compr., externamente tomentoso, marromdourado. Corola 6-15 mm compr., amarela, creme ou, às vezes, creme-rosada. Filetes 4-4,5 mm compr. em flores brevistilas, 1,5-3 $\mathrm{mm}$ compr. em flores longistilas, glabros; anteras 1,2-1,4 $\mathrm{mm}$ compr., castanho-escuras. Ovário 1,5-2 $\mathrm{mm}$ compr.; estiletes 0,5-1,7 mm compr. em flores brevistilas, 3-5 $\mathrm{mm}$ compr. em flores longistilas, glabros; estigmas penicelados. Cápsulas 4-10 $\mathrm{mm}$ diâm.; epicarpo granuloso, com tricomas esparsos. Sementes 1,8-2,5 $\times$ 1-1,4 mm, largo-obovoides, ligeiramente curvas; epiderme com papilas filiformes.

Ocorre na Bahia, Goiás, Piauí e Tocantins (Arbo 1995, 2015). D2, E3, F3: cerrados. Encontrada apenas na região oeste, em áreas abertas, terrenos baldios, encostas, margens de trilhas e rodovias. Cresce em substratos rochosos, arenosos ou argilosos, em altitudes até ca. $500 \mathrm{~m}$. Apresenta flores e frutos nos meses de novembro a maio.

Material selecionado - Angical, estrada de acesso para Angical, 1207'38"S, 4440'32"W, 26 jan. 2010 (fl., fr.), K. Yoshida-Arns et al. s.n. (UFP 60334); Barreiras, subida para a Serra da Bandeira, na margem da trilha, 1209'10"S, 4459'24"W, 3 maio 2013 (fl., fr.), $L$. Rocha 456 (CTES, HUEFS, MBM, RB, SPF); Correntina, drenagem do rio Corrente, rio Piau, ca. $225 \mathrm{~km} \mathrm{SW}$ de Barreiras, na estrada para Posse, 1320'34"S, 44³8'13"W, 12 abr. 1966 (fl., fr.), H.S. Irwin et al. 14685 (NY-foto, P-foto); Formosa do Rio Preto, fazenda Estrondo, Riachão, $11^{\circ} 06^{\prime} 50^{\prime \prime} \mathrm{S}, 45^{\circ} 28^{\prime} 20^{\prime \prime} \mathrm{W}, 502$ m, 2 maio 2009 (fl., fr.), L.P. Queiroz et al. 14458 (HUEFS); Riachão das Neves, próximo a Caripare, $11^{\circ} 48^{\prime} \mathrm{S}, 45^{\circ} 10^{\prime} \mathrm{W}, 4$ abr. 1978 (fl., fr.), J.A. Assis 110 (RB); São Desidério, estrada de terra para o Sítio Grande, $12^{\circ} 25^{\prime} \mathrm{S}, 45^{\circ} 04^{\prime} \mathrm{W}$, 4 maio 2013 (fl., fr.), L. Rocha et al. 475 (CTES, HUEFS, MBM, RB, SPF).

Pode ser reconhecida pelo hábito subarbustivo, com caules verde-escuros a castanho-avermelhados, geralmente viscosos, devido à abundância dos tricomas glandulares, e principalmente pelas sementes largoobovoides e folhas estreito-elípticas, elípticas, oblanceoladas a quase lineares, geralmente ferrugíneas. Assemelha-se vegetativamente a $P$. caiapoensis Arbo, endêmica de Goiás, a qual se diferencia pelos ramos hirsutos com folhas mais amplas e sementes obovadas, não papilosas. As flores foram encontradas abertas até 15:00 hs, visitadas por besouros.

1.5. Piriqueta carnea Urb., Repert. Spec. Nov. Regni Veg. 4: 131. 1907.

Figuras 2A-E e 18; Arbo (1995: fig. 55A-F).

Subarbustos $0,3-1,6 \mathrm{~m}$ alt.; caules denso-pilosos, tricomas tectores simples, estrelados, estrelado-porrectos e glandulares setiformes, dourados. Estípulas rudimentares. Folhas com pecíolo 5-20 mm compr.; lâmina 2-5,6 × 1,5-3 cm, papirácea, concolor a ligeiramente discolor, aplanada ou recurvada, ovada, largo-ovada a cordada, base arredondada ou cordada, ápice agudo ou obtuso, margens crenadas a sinuosas, revolutas; face adaxial hirsuta, não bulada, nervuras impressas, face abaxial tomentosa, nervuras proeminentes. Inflorescências unifloras, axilares; pedúnculo 3-8 $\mathrm{mm}$ compr.; bractéolas rudimentares. Flores heterostilas; pedicelo 3-7 $\mathrm{mm}$ compr. Cálice 1,1-1,5 cm compr., externamente tomentoso, verdeoliva a dourado. Corola $1,8-2,2 \mathrm{~cm}$ compr., salmão, base das pétalas com linhas avermelhadas. Filetes 5-7 $\mathrm{mm}$ compr. em flores brevistilas, ca. $4 \mathrm{~mm}$ compr. em flores longistilas, glabros; anteras $1-1,5 \mathrm{~mm}$ compr. Ovário 2-2,5 mm compr.; estiletes 1,7-2 mm compr. em flores brevistilas, 5-5,5 $\mathrm{mm}$ compr. em flores longistilas, glabros; estigmas pseudocapitados. Cápsulas 5-12 mm diâm.; epicarpo granulosotuberculado, hirsuto, tricomas tectores simples e glandulares setiformes, base hialina, às vezes castanhoescura. Sementes 2-2,7 $\times$ 0,9-1,1 $\mathrm{mm}$, estreitoobovoides, ligeiramente curvas; epiderme papilosa.

Rara, endêmica da Bahia (Arbo 1995; Arbo \& Giulietti 2009). C6, D5, F5: cerrados e campos rupestres. Cresce em substratos arenosos ou rochosos, em altitudes de 500-1200 m. Apresenta flores e frutos nos meses de novembro a maio.

Material selecionado - Gentio do Ouro, Serra do S. Inácio, aprox. $11^{\circ} 45^{\prime} \mathrm{S}, 42^{\circ} 31^{\prime} \mathrm{W}$, fev. 1907 (fl., fr.), E. Ule 7516 (holótipo F [foto 13552], isótipos $\mathrm{F}$ [foto 24133], HBG-foto); ib., a $47 \mathrm{~km}$ de Gentio do Ouro, $11^{\circ} 10^{\prime} 48^{\prime \prime} \mathrm{S}, 42^{\circ} 43^{\prime} 31^{\prime \prime} \mathrm{W}, 7$ maio 2002 (fl., fr.), $R$. Tourinho et al. 34 (HUEFS); Paramirim, Morro da Torre, antigo Morro da Estrela, 13을 $27^{\prime} \mathrm{S}, 42^{\circ} 38^{\prime} \mathrm{W}, 951 \mathrm{~m}, 13$ jan. 2008 (fl., fr.), U.C.S. Silva et al. 25 (HUEFS); Sento Sé, $16 \mathrm{~km}$ NE de Lagoinha, 5,5 $\mathrm{km}$ SW de Delfino, na estrada para Minas do Mimoso, $10^{\circ} 22^{\prime} \mathrm{S}$, 41 20 'W, 950-1000 m, 4 mar. 1974 (fl., fr.), R.M. Harley et al. 16682 (CEPEC, CTES, K-foto, RB); Umburanas, Serra do Curral Feio, a cerca de $20 \mathrm{~km} \mathrm{~S}$ de Delfino na estrada para Umburanas, $10^{\circ} 22^{\prime} \mathrm{S}$, 41 ${ }^{\circ} 19^{\prime} \mathrm{W}, 1000-1200$ m, 9 abr. 1999 (fl., fr.), L.P. Queiroz et al. 5153 (CTES, HUEFS).

Pode ser reconhecida pelos estigmas pseudocapitados, folhas com pecíolos longos, base arredondada ou cordada e epiderme adaxial glutinosa. Além da ocorrência, principalmente na região norte da Bahia. Piriqueta carnera se assemelha a $P$. duarteana, uma espécie amplamente distribuída, que se diferencia pelas folhas geralmente discolores de base cuneada ou atenuada e estigmas penicelados. 

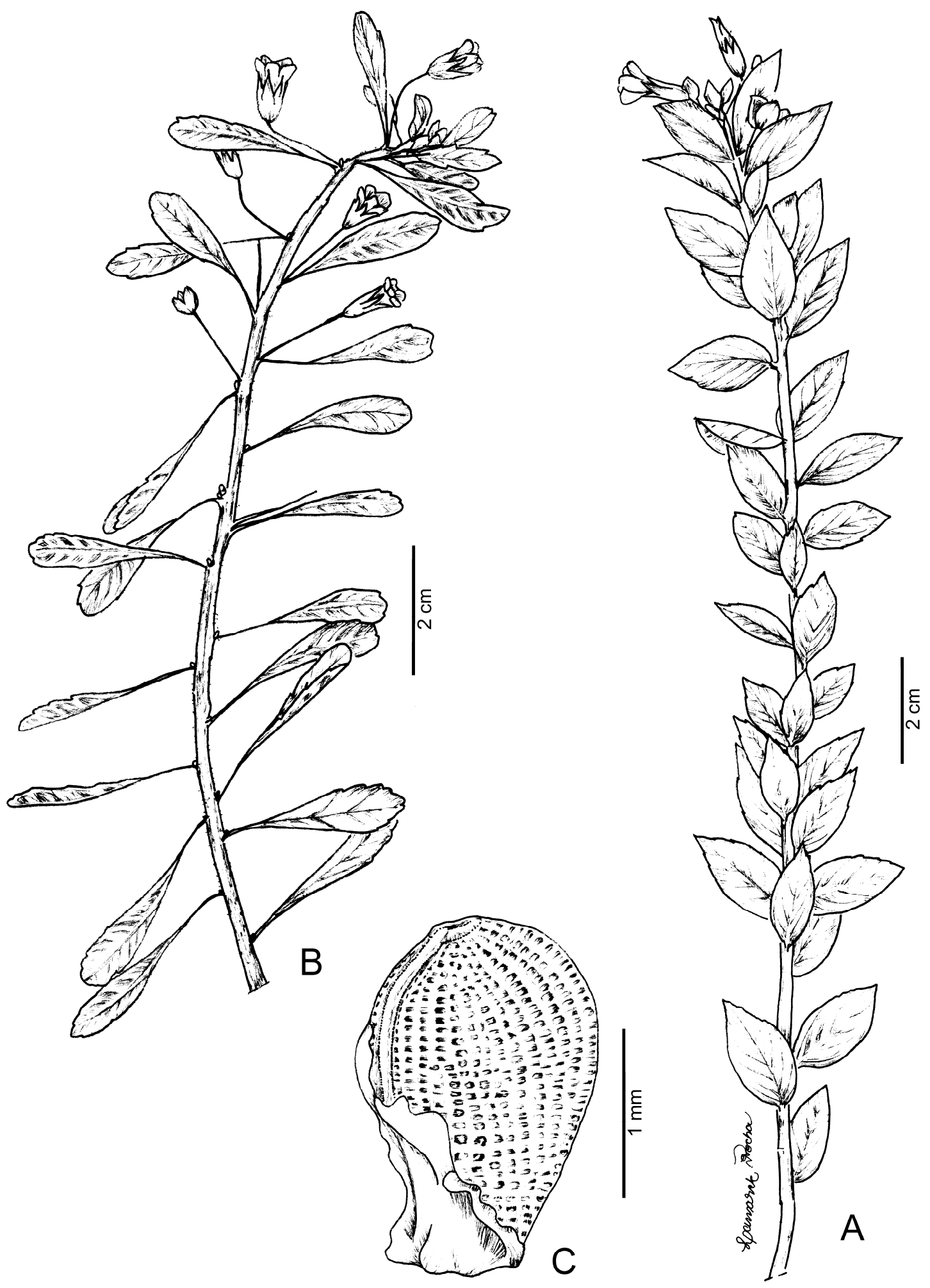

Figura 1. A. Piriqueta abairana: ramo reprodutivo (Conceição 580). B, C. P. breviseminata: B- ramo reprodutivo; C- semente (Krapovickas 38693).

1.6. Piriqueta cistoides (L.) Griseb., Fl. Brit. W.I. 3: tricomas glandulares. Estípulas rudimentares. Folhas 298. 1860.

Figuras 2F, G e 18; Arbo (1995: fig. 57A-F e 58A-R).

Ervas ou arbustos $0,2-1(-2) \mathrm{m}$ alt.; caules quase glabros, hirsutos a híspidos, tricomas tectores simples, estrelados e estrelado-porrectos, ferrugíneos, sem com pecíolo até ca. $7 \mathrm{~mm}$ compr.; lâmina $0,5-7,5 \times$ $0,1-1,5 \mathrm{~cm}$, papirácea, concolor a sutilmente discolor, ligeiramente recurvada, ovada, elíptica, obovada, lanceolada a linear, base cuneada, atenuada, arredondada, raro assimétrica, ápice obtuso ou agudo, 
margens serreado-crenadas a inteiras, planas ou revolutas; face adaxial esparso-pilosa, às vezes hirsuta, não bulada, nervuras impressas, face abaxial tomentoso-hirsuta, nervuras proeminentes. Inflorescências unifloras, solitárias, axilares; pedúnculo 1,5-3,3 cm compr.; bractéolas ausentes. Flores heterostilas ou homostilas; pedicelo (2-)5-7 $\mathrm{mm}$ compr. Cálice 4,5-10 mm compr., externamente tomentoso ou hirsuto, marrom-dourado. Corola 1,3-2,5 cm compr., amarela ou amarelo-alaranjada, base das pétalas amarelo-escura. Filetes 2,2-7, glabros; anteras 1-1,7 mm compr. Ovário 1,7-2 mm compr.; estiletes 0,9-4 mm compr., glabros; estigmas penicelados. Cápsulas 4-5 mm diâm.; epicarpo liso, glabro ou esparso-piloso. Sementes 1,5-1,7 × 0,9-1 mm, obovoides, retas ou ligeiramente curvas; epiderme papilosa, nós do retículo não proeminentes.

Trata-se da espécie com maior distribuição do gênero. Ocorre desde o sul dos Estados Unidos até o norte da Argentina (Arbo 1995). No Brasil, está representada em quase todos os estados (Arbo 2015). A9, B7, B9, C3, C5, D4, D5, D6, E2, E5, E6, E7, F4, F6, G3, G4, G5, H8, H9, J8: caatingas, cerrados, restingas, dunas, matas ciliares e matas ombrófilas. Habita áreas com vegetação aberta ou densa, em afloramentos rochosos, margens de rios, áreas brejosas ou alagáveis, além de trilhas, rodovias e terrenos baldios. Cresce em substratos arenosos, rochosos ou argilosos, em altitudes até $1000 \mathrm{~m}$. Apresenta flores e frutos o ano todo.

Material selecionado - Andaraí, APA dos Marimbus, $12^{\circ} 46^{\prime} 00^{\prime \prime S}, 41^{\circ} 18^{\prime} 38^{\prime \prime W}, 317$ m, 5 fev. 2011 (fl., fr.), E. Melo et al. 9005 (HUEFS); Barra, Ibiraba, 10² $7^{\prime} \mathrm{S}, 42^{\circ} 49^{\prime} \mathrm{W}, 4$ jun. 2000 (f1.), A.T. Rodarte 106 (CTES); Belmonte, $15^{\circ} 51^{\prime} \mathrm{S}, 38^{\circ} 52^{\prime} \mathrm{W}, 31$ ago. 2003 (fl., fr.), M.L. Guedes et al. 10679 (ALCB, HRB); Bom Jesus da Lapa, $22,3 \mathrm{~km}$ a SE da cidade na BR-433, $13^{\circ} 15^{\prime} 18^{\prime \prime} \mathrm{S}$,

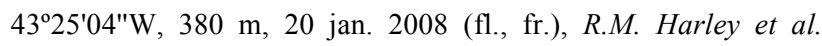
55756 (HUEFS); Carinhanha, Médio São Francisco, 14¹9'49"S, 434' $40^{\prime \prime W}, 445$ m, 25 nov. 2007 (f1.), M.L. Guedes et al. 13962 (ALCB, HUEFS); Contendas do Sincorá, na estrada de Sussuarana, 134ㄴ' $46^{\prime \prime} \mathrm{S}, 41^{\circ} 02^{\prime} 27^{\prime \prime} \mathrm{W}, 4$ nov. 2010 (fl., fr.), R.M. Harley et al. 56193 (HUEFS); Feira da Mata, $23 \mathrm{~km}$ de Cocos, $14^{\circ} 15^{\prime} 04^{\prime \prime S}, 44^{\circ} 22^{\prime} 10^{\prime \prime} \mathrm{W}, 500 \mathrm{~m}, 17$ abr. 2001 (fl., fr.), J.G. Jardim et al. 3592 (ALCB, CEPEC, CTES, HRB, HUEFS, NY-

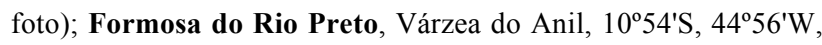
23 fev. 2005 (fl., fr.), A.B. Xavier \& M.L. Guedes 288 (ALCB); Gentio do Ouro, lagoa Itaparica, $10 \mathrm{~km} \mathrm{~W}$ de São Inácio-Xique Xique, estrada a $13,1 \mathrm{~km}$ norte de São Inácio, $11^{\circ} 01^{\prime} \mathrm{S}, 42^{\circ} 46^{\prime} \mathrm{W}$, 300-400 m, 26 fev. 1977 (fl., fr.), R.M. Harley et al. 19094 (CTES, E-foto, K-foto, M-foto, MBM, RB); Guanambi, BR-122, fazenda Capoeira, 14 $13^{\prime} \mathrm{S}, 4^{\circ} 37^{\prime} \mathrm{W}, 10$ mar. 1998 (fl., fr.), $G$. Hatschbach et al. 67578 (C-foto, CTES, INPA-foto, MBM); Iaçu, rio Paraguaçu, próximo à ponte na entrada da cidade, $12^{\circ} 45^{\prime} \mathrm{S}$, $40^{\circ} 12^{\prime} \mathrm{W}, 215$ m, 5 fev. 2005 (fl., fr.), J. Paula-Souza et al. 5475 (CTES, ESA); Itaetê, zona rural, margens do rio Paraguassu, $13^{\circ} 00^{\prime} \mathrm{S}, 41^{\circ} 37^{\prime} \mathrm{W}, 19$ jan. 2012 (fl., fl.), L. Rocha et al. 364 (CTES, HUEFS, RB); Juazeiro, 09²4'50"S, 40³0'10"W, 26 fev. 1962 (fl., fr.), A.L. Costa s.n. (ALCB 2835, CTES); Jussara, Baixão dos Honoratos, $11^{\circ} 05^{\prime} \mathrm{S}, 41^{\circ} 49^{\prime} \mathrm{W}, 610$ m, 3 abr. 1984 (fl., fr.), O.A.
Salgado \& H.P. Bautista 343 (CEPEC, HRB, IPA, MBM, RB); Livramento de Nossa Senhora, estrada para Lagoa Nova,

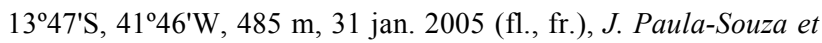
al. 5199 (CTES, ESA); Luiz Eduardo Magalhães, BR-626 para a BR-242, 1205'16"S, 4545'12"W, 762 m, 28 nov. 2003 (fl., fr.), B.A. Anjos et al. 151 (ALCB); Malhada, rodovia para o distrito de Cana Brava, $3,5 \mathrm{~km}$ ao $\mathrm{S}$ da cidade, $14^{\circ} 21^{\prime} 42^{\prime \prime} \mathrm{S}, 43^{\circ} 45^{\prime} 14^{\prime \prime} \mathrm{W}$, 450 m, 2 abr. 2001 (fl., fr.), J.G. Jardim et al. 3408 (ALCB, CEPEC, CTES, HRB, HUEFS, NY-foto); Morpará, na beira do Rio Paramirim, $11^{\circ} 35^{\prime} \mathrm{S}, 43^{\circ} 17^{\prime} \mathrm{W}, 280 \mathrm{~m}, 16$ dez. 2007 (fl., fr.), A.A. Conceição et al. 2676 (HUEFS); Mucugê, 1301'09"S, 41 $25^{\prime} 34^{\prime \prime W}, 1000$ m, 2 nov. 2007 (fl., fr.), E. Melo et al. 5398 (HUEFS); Palmas de Monte Alto, arredores, $14^{\circ} 14^{\prime} \mathrm{S}, 43^{\circ} 01^{\prime} \mathrm{W}$, 430 m, 30 dez. 2004 (fl., fr.), G. Hatschbach \& E. Barbosa 78727 (MBM); Paulo Afonso, Ilha dos Urubus, no rio São Francisco, 09²4'28"S, 38¹3'19"W, abr. 1954 (fl., fr.), J. Vidal IV-793 (R); Prado, 1540'S, 38 $59^{\prime} \mathrm{W}, 3$ maio 2002 (fl., fr.), P.P. Oliveira et al. 91 (HUEFS); Queimadas, beira do rio São Francisco, 11 $37^{\circ} \mathrm{S}$, 42으'W, 12 out. 1990 (fl., fr.), A. Freire-Fierro et al. 1899 (CTES, SPF); Riacho de Santana, ca. $24 \mathrm{~km}$ E de Bom Jesus da Lapa, estrada para Caetité, $13^{\circ} 23^{\prime} 47^{\prime \prime S}, 43^{\circ} 13^{\prime} 30^{\prime \prime} \mathrm{W}, 460 \mathrm{~m}, 12$ fev. 2000 (fl., fr.), L.P. Queiroz 5900 (CTES, HUEFS); Rio Verde, 10 52'S, $42^{\circ} 14^{\prime} \mathrm{W}, 15$ jun. 1978 (fl., fr.), C.A. Miranda 261 (HRB, RB); Rodelas, 0851'03"S, 38 45'21"W, 21 jan. 1987 (fl., fr.), G.O.M. Silva \& L.B. Silva 24 (HRB, HUEFS); Santa Maria da Vitória, rio São Francisco, ponte para Santa Maria da Vitória, 131' $\mathrm{S}, 43^{\circ} 27^{\prime} \mathrm{W}$, 4 abr. 1992 (fl., fr.), G. Hatschbach et al. 56583 (CTES, MBM); Seabra, estrada para Xique-Xique, $10^{\circ} 48^{\prime} 34^{\prime \prime} \mathrm{S}, 42^{\circ} 43^{\prime} 38^{\prime \prime} \mathrm{W}, 510 \mathrm{~m}$, 22 jun. 1996 (fl., fr.), R.M. Harley et al. PCD 2930 (ALCB, CEPEC, HRB, SPF); Serra do Ramalho, ca. $18 \mathrm{~km}$ da cidade, entrada pela agrovila $10,13^{\circ} 30^{\prime} 38^{\prime \prime} \mathrm{S}, 43^{\circ} 45^{\prime} 08^{\prime \prime} \mathrm{W}, 510 \mathrm{~m}, 14 \mathrm{abr}$. 2001 (fl., fr.), J.G. Jardim et al. 3478 (CEPEC, CTES, HUEFS, NY-foto); Una, fazenda Bolandeira, ca. $3 \mathrm{~km}$ de Comandatuba, $15^{\circ} 18^{\prime} 57^{\prime \prime S}, 39^{\circ} 00^{\prime} 03^{\prime \prime W}, 5-10 \mathrm{~m}, 2$ nov. 2001 (fl., fr.), W.W. Thomas et al. 12715 (CEPEC, NY-foto, RB); Xique-Xique, Boa Vista, estrada para Velha Marreca, 10 49'19"S, 42 $43^{\prime} 51^{\prime \prime} \mathrm{W}, 14$ mar. 1998 (fl., fr.), G. Hatschbach et al. 67757 (CTES, MBM).

Pode ser reconhecida pelas flores solitárias, de corola amarela ou amarelo-alaranjada, frutos com epicarpo liso, sementes retas ou ligeiramente curvas e aréolas com uma depressão puntiforme, além do indumento composto apenas por tricomas tectores. Assemelha-se a Piriqueta racemosa, a qual se diferencia pelas flores dispostas em um racemo terminal áfilo alongado e sementes fortemente curvas com nós do retículo proeminentes. Alguns exemplares do município de Bom Jesus da Lapa (Jardim 3478, Harley 21443, Queiroz 5751, Queiroz 5749 e Queiroz 5900) são quase glabros, com folhas estreitas e sementes curvas, com nós do retículo proeminentes, o que se trata de uma variação da espécie.

Arbo (1995) considerou duas subespécies para $P$. cistoides: Piriqueta cistoides subsp. cistoides e $P$. cistoides subsp. caroliniana Arbo; ambas ocorrem na Bahia. Em aspecto geral, $P$. cistoides subsp. cistoides abrange ervas anuais, com flores homostilas, enquanto $P$. cistoides subsp. caroliniana são subarbustos perenes, com flores heterostilas maiores que na subespécie típica. 


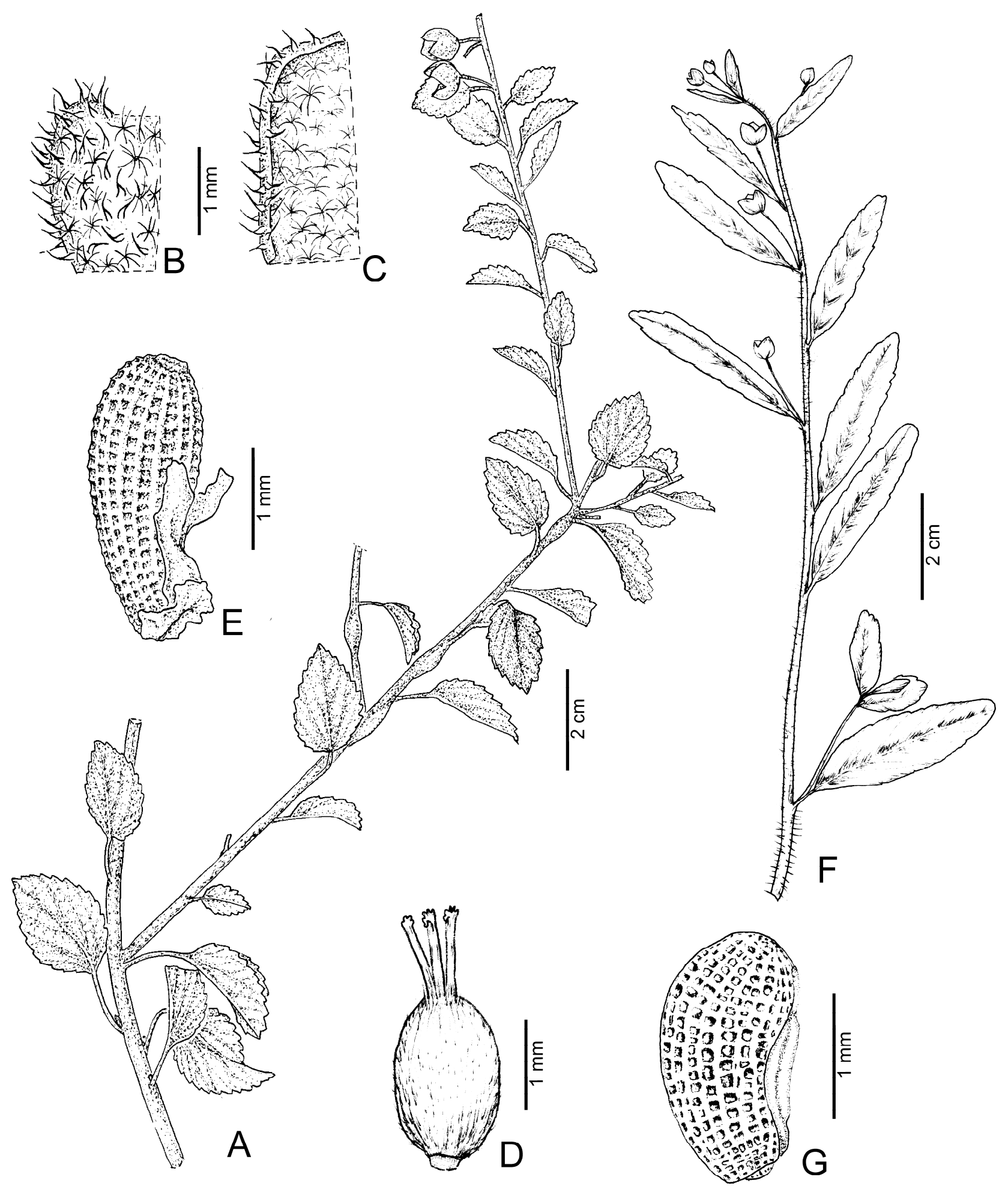

Figura 2. A-E. Piriqueta carnea: A- ramo reprodutivo; B- detalhe de face adaxial da folha; C- detalhe de face abaxial da folha; D- gineceu (flor brevistila); E- semente (Tourinho 34). F, G. P. cistoides: F- ramo reprodutivo; G- semente (Xavier 288) (A-C, E. por Liliana Gomes).

1.7. Piriqueta constellata Arbo, Kew Bull. 48(1): 9. 1993.

Figuras 19; Arbo (1995: fig. 22A-D); Rocha \& Moreira (2014: foto 4).

Subarbustos ou arbustos $0,3-1,3 \mathrm{~m}$ alt.; caules tomentosos, escabrosos a fortemente hirsutos, tricomas tectores estrelados e estrelado-porrectos de base globosa, inchada, dourados a ferrugíneos, perceptíveis a olho nu, tricomas glandulares ausentes. Estípulas reduzidas a 1-3 coléteres. Folhas com pecíolo 1-7 mm compr.; lâmina 1,5-5,6 × 1,2-4 cm, coriácea, discolor, aplanada, ovada, largo-ovada a circular, base 
arredondada a cordada, ápice obtuso a agudo, margens denteado-crenadas, planas ou revolutas; face adaxial denso-pilosa, tricomas estrelados e estrelado-porrectos de base globosa, perceptíveis a olho nu, não bulada, nervuras impressas, face abaxial tomentosa, nervuras proeminentes. Inflorescências em cincinos 2-7-floros, axilares; pedúnculo 0,6-2,4 cm compr.; bractéolas 1-4 mm compr., linear-triangulares. Flores heterostilas; pedicelo 1-5 $\mathrm{mm}$ compr. Cálice 6-11 mm compr., externamente tomentoso, ferrugíneo. Corola 1,1-1,5 cm compr., creme, amarela, amarelo-alaranjada, raro salmão. Filetes 4-5 mm compr. em flores brevistilas, ca. $4 \mathrm{~mm}$ compr. em flores longistilas, glabros; anteras 1,8-3 mm compr. Ovário 1,5-2 mm compr.; estiletes 1-2 mm compr. em flores brevistilas, 3-4,5 $\mathrm{mm}$ compr. em flores longistilas, glabros; estigmas penicelados. Cápsulas $8-11 \mathrm{~mm}$ diâm.; epicarpo tuberculado, tomentoso-hirsuto. Sementes 2,5-3 $\times$ 0,9-1 mm, obovoides, ligeiramente curvas; epiderme densamente papilosa.

Ocorre nos estados da Bahia e Minas Gerais (Arbo 2015). E6, F6: caatingas, cerrados e campos rupestres. Habita áreas abertas, em afloramento rochosos, encostas, margens de trilhas e rodovias. Cresce entre as rochas, em substratos arenosos, argilosos ou rochosos, em altitudes de 1066-1375 m. Apresenta flores e frutos durante a maior parte do ano.

Material selecionado - Abaíra, Engenho de Baixo, Morro do Cuscuzeiro, estrada Casa Velha de Arthur para Boa Vista, $12^{\circ} 59^{\prime} \mathrm{S}, 41^{\circ} 49^{\prime} \mathrm{W}, 1150 \mathrm{~m}, 10$ jul. 1994 (fl., fr.), W. Ganev 3486 (CTES, HUEFS, K-foto, SPF); Ituaçu, $14 \mathrm{~km}$ da cidade,

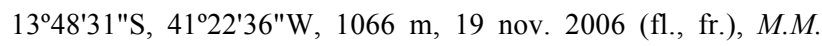
Silva-Castro et al. 1043 (HUEFS); Mucugê, estrada para o vale do Guiné, $13^{\circ} 00^{\prime} \mathrm{S}, 41^{\circ} 37^{\prime} \mathrm{W}, 17$ jan. 2012 (fl., fl.), L. Rocha et al. 356 (CTES, HUEFS, RB); Palmeiras, estrada para o Capão, 12³4'79"S, 41³0'76"W, 981 m, 29 abr. 2012 (fl., fl.), L. Rocha \& I. Souza 369 (CTES, HUEFS, RB); Piatã, estrada para Inúbia, 130'11"S, 4128'24"W, 1375 m, 19 dez. 2009 (fl., fr.), F.S. Gomes et al. 479 (ALCB); Rio de Contas, estrada para Brumadinho, $13^{\circ} 31^{\prime} \mathrm{S}, 41^{\circ} 54^{\prime} \mathrm{W}, 1252 \mathrm{~m}, 26$ set. 2005 (fl., fr.), M.G. Bovini et al. 2518 (CTES, RB); Seabra, Serra do Roncador, $12^{\circ} 18^{\prime} 41^{\prime \prime S}, 41^{\circ} 50^{\prime} 28^{\prime \prime W}, 1310 \mathrm{~m}, 3$ set. 1997 (fl., fr.), H.P. Bautista \& J. Oubiña 2240 (HRB).

Poder ser reconhecida pelas folhas coriáceas, com indumento dourado a ferrugíneo, escabroso a fortemente hirsuto, apresentando principalmente tricomas estrelados de base globosa e inchada, facilmente visíveis na face adaxial da lâmina. Suas flores são chamativas, com pétalas geralmente amarelas e corona escura; foram encontradas ainda abertas até 14:00 hs, visitadas por besouros, borboletas e pequenas aranhas verdes. Em Harley 24649, a corola é descrita como salmão, em outros exemplares como alaranjada, algo que não é comum nesta espécie. Tratase da única espécie do gênero com inflorescências cimosas desprovidas de tricomas glandulares setiformes (Arbo 1993, 1995). Assemelha-se a Piriqueta dentata, que se diferencia pelo indumento com tricomas glandulares setiformes e estrelado- porrectos menores, além das inflorescências mais curtas, com flores de corola em tons de rosa.

1.8. Piriqueta crenata L.Rocha, I.M.Souza \& Arbo, Phytotaxa 159(2):105. 2014.

Figuras 19; Rocha et al. (2014: fig. 1A-T).

Subarbustos 30-40 cm alt.; caules esparso-pilosos, tricomas tectores simples e glandulares setiformes, marrom-dourados. Estípulas reduzidas a coléteres ca. $0,3 \mathrm{~mm}$ compr. Folhas com pecíolo $2-5 \mathrm{~mm}$ compr.; lâmina $1-2,8 \times 0,6-2,1 \mathrm{~cm}$, papirácea, ligeiramente discolor, aplanada, elíptica a elíptico-obovada, base atenuada a cuneada, ápice obtuso, margens fortemente crenadas, revolutas; face adaxial esparso-hirsuta, profundamente bulada, nervuras impressas, face abaxial tomentosa, nervuras proeminentes. Inflorescências em cincinos 1-3-floros, axilares; pedúnculo 1-1,3 cm compr.; bractéolas 0,4-1,5 mm compr., linear-triangulares ou reduzidas a um tufo de tricomas. Flores heterostilas; pedicelo 4-10 $\mathrm{mm}$ compr. Cálice 9-12 mm compr., externamente esparsohirsuto, marrom-dourado. Corola 1,5-1,6 cm compr., amarela. Filetes 4-5 mm compr. em flores brevistilas, ca. 2,5 $\mathrm{mm}$ compr. em flores longistilas, glabros; anteras 1-2,4 mm compr. Ovário 1-1,5 mm compr.; estiletes ca. 2,5 $\mathrm{mm}$ compr. em flores brevistilas, ca. 4 $\mathrm{mm}$ compr. em flores longistilas, base glabra ou pubescente; estigmas penicelados. Cápsulas ca. $5 \times 4$ mm diâm.; epicarpo tenuamente verrucoso, esparsopiloso. Sementes ca. $3 \times 1,6 \mathrm{~mm}$, obovoides, retas; epiderme papilosa.

Rara, endêmica da porção norte da Chapada Diamantina. D6: cerrados. Habita áreas abertas, entre afloramentos rochosos. Cresce em substratos arenosos ou argilosos, em altitudes ca. 1060-1070 m. Encontrada com flores e frutos em maio e julho.

Material examinado - Morro do Chapéu, fazenda Guariba, nascentes do rio Salitre, $11^{\circ} 26^{\prime} 08^{\prime \prime} \mathrm{S}, 41^{\circ} 11^{\prime} 34^{\prime \prime} \mathrm{W}, 1065 \mathrm{~m}, 1$ jul. 2007 (fl., fr.), E. Melo et al. 4941 (holótipo HUEFS, isótipos CTES,

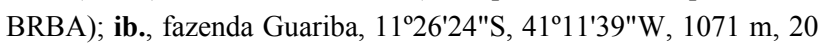
maio 2007 (fl.), J.F.B. Pastore et al. 2082 (parátipo HUEFS).

Pode ser reconhecida pelas folhas crenadas, com superfície adaxial marcadamente bulada, inflorescências 1-3-floras, com pedúnculos bem desenvolvidos e flores de corola amarela. As folhas são similares às de $P$. flammea, uma espécie restrita aos campos rupestres e carrascos dos municípios de Rio de Contas e Piatã, que se diferencia pelas flores de corola vermelho-alaranjada a vermelha, agrupadas em inflorescências 3-6-floras.

1.9. Piriqueta densiflora Urb., Repert. Spec. Nov. Regni Veg. 4: 129. 1907.

Figuras 19; Arbo (1995: fig. 27A-D); Rocha \& Moreira (2014: fotos 5 e 6).

Subarbustos ou arbustos 0,2-2 m alt.; caules tomentosos, tricomas tectores simples, estrelados e estrelado-porrectos, dourados. Estípulas até ca. $0,5 \mathrm{~mm}$ compr. Folhas com pecíolo 2-8 $\mathrm{mm}$ compr.; lâmina 
(1-)2,5-10 × 0,3-2,9 cm, cartácea, discolor, aplanada ou recurvada, estreito-oblonga, estreito-elíptica a linear, base arredondada a cuneada, ápice agudo a obtuso, margens crenadas, serreado-crenadas a crenado-sinuadas, revolutas; face adaxial tomentosa, às vezes velutina, bulada ou não, nervuras profundamente impressas, face abaxial tomentoso-velutina, nervuras proeminentes. Inflorescências em cincinos (3-)8-20floros, axilares; pedúnculo 4-18 $\mathrm{mm}$ compr.; bractéolas 0,4-3 $\mathrm{mm}$ compr., linear-triangulares. Flores heterostilas; pedicelo 2-5 $\mathrm{mm}$ compr. Cálice 5$9 \mathrm{~mm}$ compr., externamente tomentoso, marromdourado. Corola 7-11 $\mathrm{mm}$ compr., amarela ou amarelo-alaranjada. Filetes $4-5 \mathrm{~mm}$ compr. em flores brevistilas, 2-3 $\mathrm{mm}$ compr. em flores longistilas, glabros; anteras 0,7-2 $\mathrm{mm}$ compr. Ovário 1,5-2 mm compr.; estiletes 1-1,5 $\mathrm{mm}$ compr. em flores brevistilas, 2,5-4 $\mathrm{mm}$ compr. em flores longistilas, glabros; estigmas penicelados. Cápsulas 4-7 $\mathrm{mm}$ diâm.; epicarpo granuloso, denso-estrigoso. Sementes 2-3 × 0,7-1,3 mm, estreito-obovoides a claviformes, ligeiramente curvas; epiderme papilosa.

Ocorre no estado de Goiás e, principalmente, nas regiões norte e oeste da Bahia (Arbo 1995, 2015). C3, C8, D3, D5, D7, E2/3, F3, G2: caatingas e cerrados. Habita áreas abertas, encostas, margens de trilhas e rodovias e em terrenos baldios sujeitos a queimadas. Cresce em substratos argilosos e rochosos, em altitudes 500-840 m. Apresenta flores e frutos praticamente o ano todo.

Material selecionado - Barreiras, subida para a Serra da Bandeira, 1209'10"S, 44'59'24"W, 3 maio 2013 (fl., fr.), L. Rocha 455 (CTES, HUEFS, MBM, RB, SPF); Cocos, fazenda Trijunção, $14^{\circ} 52^{\prime} 50^{\prime \prime} \mathrm{S}, 46^{\circ} 02^{\prime} 48^{\prime \prime} \mathrm{W}, 840 \mathrm{~m}, 15$ maio 2001 (fl., fr.), M.L. Fonseca et al. 2679 (CTES, IBGE); Correntina, ca. $43 \mathrm{~km} \mathrm{~W}$ de Santa Maria da Vitória, na estrada para Correntina, 13⒉ $3^{\prime} 12^{\prime \prime S}$, 443' $54^{\prime \prime S}, 610$ m, 15 fev. 2000 (fl.), L.P. Queiroz et al. 6039 (ALCB, CEPEC, CTES, HUEFS); Gentio do Ouro, arredores de Santo Inácio e até $9 \mathrm{~km}$ ao norte, estrada para Xique-Xique, Serra do Açuruá, $11^{\circ} 05^{\prime} \mathrm{S}, 42^{\circ} 44^{\prime} \mathrm{W}, 27$ nov. 1992 (fl., fr.), M.M. Arbo et al. 5322 (C-foto, CTES, F-foto, GH-foto, HUEFS, IPA, K-foto, LIL-foto, MBM, MICH-foto, MO-foto, NY-foto, RB, SPF, U-foto, UB, US-foto, WIS-foto, YUTO-foto); Jacobina, Serra da Jaboticaba,

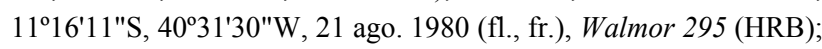
Queimadas, as Pedras, local no lado do Rio São Francisco, $10^{\circ} 58^{\prime} 40^{\prime \prime} \mathrm{S}, 39^{\circ} 37^{\prime} 26^{\prime \prime} \mathrm{W}, 13$ out. 1990 (fl., fr.), A. Freire-Fierro et al. 1929 (CTES, SPF); Santa Rita de Cássia, BA-135, 40 km antes de Formosa do Rio Preto, $2 \mathrm{~km}$ antes do povoado Entroncamento, $11^{\circ} 00^{\prime} 32^{\prime \prime S}, 44^{\circ} 31^{\prime} 08^{\prime \prime W}, 5$ maio 2013 (fl., fr.), L. Rocha et al. 482 (ALCB, CTES, HUEFS, MBM, RB, SPF); São Desidério, $15 \mathrm{~km}$ após a entrada da comunidade Palmeiral, $12^{\circ} 21^{\prime} 46^{\prime \prime} \mathrm{S}, 44^{\circ} 58^{\prime} 22^{\prime \prime} \mathrm{W}, 4$ maio 2013 (fl., fr.), L. Rocha et al. 461 (CTES, HUEFS, MBM, RB, $\mathrm{SPF}$ ); Xique-Xique, estrada Xique-Xique a Barra, ca. $21 \mathrm{~km}$ a partir da sede do município, 1049'19"S, 4243'51"W, 28 abr. 1999 (fl., fr.), A.M. Amorim et al. 3033 (CEPEC, CTES, MBM, SP).

Pode ser reconhecida pelas folhas estreito-oblongas, estreito-elípticas a lineares, com margens geralmente crenadas e face adaxial ferrugínea ou verdeacinzentada quando seca, com nervuras profundamente impressas, além da corola amarela ou alaranjada e sementes com epiderme papilosa, com até 2 depressões puntiformes nas aréolas do retículo. Suas flores são chamativas e foram encontradas abertas até 14:00 hs; visitadas por besouros. Assemelha-se a P. sidifolia, uma espécie com ampla distribuição no Brasil que se diferencia pelas folhas geralmente ovadas, com base arredondada a cordada e ápice geralmente agudo.

Arbo (1995) considerou duas variedades para essa espécie: $P$. densiflora var. densiflora e $P$. densiflora var. goiasensis Arbo, ambas com ocorrência na Bahia. A variedade típica possui inflorescências (4-)8-20floras, cálice 7-9 mm compr. e folhas obtusas no ápice, equanto $P$. densiflora var. goiasensis se diferencia por apresentar menos flores por inflorescência (3-5-floras), cálice menor (5-6 $\mathrm{mm}$ compr.) e folhas com ápice agudo.

\subsection{Piriqueta dentata Arbo, Fl. Neotrop. Monogr.} 67: 40. 1995.

Figuras 20; Arbo (1995: fig. 22E-J); Rocha \& Moreira (2014: fotos 7 e 8 ).

Arbustos a subarbustos 0,2-1,5 m alt.; caules tomentoso-hirsutos, tricomas tectores simples e estrelado-porrectos ferrugíneos e glandulares setiformes, esparsos. Estípulas até ca. 0,5 mm compr. Folhas com pecíolo 1-6 mm compr.; lâmina 1,5-3,5(5) $\times 1,1-2,5(-4) \mathrm{cm}$, cartácea a quase coriácea, discolor, aplanada, ovada, elíptica ou subcircular, base arredondada, cuneada ou atenuada, ápice agudo a obtuso, margens denteadas, serreado-crenadas, planas ou revolutas; face adaxial tomentosa-hirsuta, não bulada, nervuras impressas, face abaxial tomentosa, nervuras proeminentes. Inflorescências em cincinos 1-3-floros; pedúnculo (3-)7-25 mm compr.; bractéolas 0,5-2 mm compr., linear-triangulares. Flores heterostilas; pedicelo 3-7 mm compr. Cálice 9-18 mm compr., externamente tomentoso, ferrugíneo. Corola 1,2-2,3 cm compr., rosa a salmão, base das pétalas amarela ou roxa. Filetes $5-8 \mathrm{~mm}$ compr. em flores brevistilas, 3-4 $\mathrm{mm}$ compr. em flores longistilas, glabros; anteras 1,3-3 mm compr. Ovário 2-2,5 $\mathrm{mm}$ compr.; estiletes 1,5-2 $\mathrm{mm}$ compr. em flores brevistilas, 4-5,5 $\mathrm{mm}$ compr. em flores longistilas, glabros ou esparso-pilosos; estigmas penicelados. Cápsulas 5-10 mm diâm.; epicarpo tuberculado, tomentoso-hirsuto, tricomas estrelados e estreladoporrectos. Sementes 2,5-3,2(-3,6) × 1-1,3(-1,5) mm, obovoides, ligeiramente curvas; epiderme papilosa.

Rara, endêmica da porção norte da Chapada Diamantina (Arbo 1995). C6, D6: cerrados, caatingas e campos rupestres. Habita áreas abertas, por vezes terrenos baldios, margens de trilhas e rodovias. Cresce em substratos arenosos, argilosos e rochosos, em altitudes de 500-1200 m. Apresenta flores e frutos durante a maior parte do ano.

Material selecionado - Morro do Chapéu, $3 \mathrm{~km} \mathrm{~S}$ da cidade, caminho para Utinga, $11^{\circ} 35^{\prime} \mathrm{S}, 41^{\circ} 11^{\prime} \mathrm{W}, 28$ nov. 1992 (fl., fr.), M.M. Arbo et al. 5359 (holótipo SPF, isótipos C-foto, CTES, G-foto, 
HUEFS, IPA, K-foto, MBM, MO-foto, NY-foto, P-foto, RB, SIfoto, SP, UB, US-foto); ib., BA-052, a $18 \mathrm{~km}$ da cidade, estrada para a cachoeira do Ferro Doido, $11^{\circ} 33^{\prime} 00^{\prime \prime} \mathrm{S}, 41^{\circ} 09^{\prime} 21^{\prime \prime W}, 28$ jan. 2013 (fl.), L. Rocha \& B.S. Gregório 381 (CTES, HUEFS, RB); Umburanas, Serra do Curral Feio, $18 \mathrm{~km}$ NE de Lagoinha, 10²4'58"S, 41¹9'33"W, 950 m, 7 mar. 1974 (fl., fr.), R.M. Harley et al. 16944 (CEPEC, K-foto, RB).

Pode ser reconhecida pelo indumento densohirsuto e ferrugíneo, com tricomas de raios longos, 2 $4 \mathrm{~mm}$ compr., folhas com margens denteadas a serreado-crenadas, além das flores de corola rosada, com base das pétalas amarela ou roxa e unha também roxa. $\mathrm{O}$ número de flores na inflorescência pode variar, às vezes aquelas dos nós inferiores podem ser unifloras. Assemelha-se a $P$. duarteana e $P$. constellata; a primeira se diferencia pelas inflorescências unifloras e epicarpo com tricomas glandulares setiformes de base escura e a segunda se diferencia pelos tricomas estrelados de base globosa, inchada, visíveis a olho nu, e inflorescências com maior número de flores.

\subsection{Piriqueta douradinha Arbo, Fl. Neotrop.} Monogr. 67: 41. 1995.

Figuras 20; Arbo (1995: fig. 24A-E); Rocha \& Moreira (2014: foto 9).

Arbustos de pequeno porte $40-80 \mathrm{~cm}$ alt.; caules tomentosos, tricomas tectores simples, estreladoporrectos dourados e glandulares setiformes de base esbranquiçada. Estípulas ausentes. Folhas com pecíolo 1-3(-4) mm compr.; lâmina 7-11(-20) × 3-11 mm, cartácea, ligeiramente discolor, aplanada, ovada, elíptica, obovada ou subcircular, base arredondada, atenuada ou cuneada, ápice obtuso, margens crenadas, revolutas; face adaxial tomentosa, bulada, nervuras profundamente impressas, face abaxial tomentosa, nervuras proeminentes. Inflorescências em cincinos 1-3-floros; pedúnculo 0,5-13 mm compr.; bractéolas 0,5-2,5 $\mathrm{mm}$ compr., linear-triangulares. Flores heterostilas; pedicelo 1-2,5 mm compr. Cálice 7-12 mm compr., externamente tomentoso-hirsuto, ferrugíneo. Corola 1,1-1,3 cm compr., amarela. Filetes ca. $5 \mathrm{~mm}$ compr. em flores brevistilas, 3-4,5 $\mathrm{mm}$ compr. em flores longistilas; anteras 1-2 mm compr. Ovário 1,5-3 mm compr.; estiletes ca. 1,5 $\mathrm{mm}$ compr. em flores brevistilas, 3,5-5 $\mathrm{mm}$ compr. em flores longistilas, esparso-pilosos ou glabros; estigmas penicelados. Cápsulas 3,5-6 $\mathrm{mm}$ diâm.; epicarpo tenuamente verrucoso, hirsuto, com tricomas tectores estrelados e glandulares setiformes de base, às vezes, esbranquiçada. Sementes 2-3 × ca. $1 \mathrm{~mm}$, obovoides, retas a ligeiramente curvas; epiderme papilosa.

Rara, endêmica da porção central da Chapada Diamantina, na Bahia (Arbo 1995; Arbo \& Giulietti 2009). F6: cerrados e campos rupestres. Habita áreas abertas, às vezes em margens de rios, trilhas ou rodovias, entre as rochas, em substratos arenosos, rochosos, em altitudes de 890-1290 m. Apresenta flores e frutos nos meses de maio a novembro.
Material selecionado - Barra da Estiva, $20 \mathrm{~km}$ NE de Barra da Estiva, estrada para Sincorá Velho, $13^{\circ} 32^{\prime} \mathrm{S}, 41^{\circ} 15^{\prime} \mathrm{W}$, ca. $890 \mathrm{~m}$, 23 nov. 1992 (fl., fr.), M.M. Arbo et al. 5743 (CTES, HUEFS, Kfoto, SPF, UB); Ituaçu, estrada Ituaçu-Barra da Estiva, a $8 \mathrm{~km}$ de

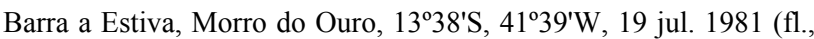
fr.), A.M. Giulietti et al. CFCR 1285 (holótipo SPF, isótipos CTES, K-foto, MO-foto); Mucugê, $13^{\circ} 00^{\prime} \mathrm{S}, 4^{\circ} 22^{\prime} \mathrm{W}, 11$ nov. 2006 (fl., fr.), M.L. Guedes et al. 16317 (HUEFS); Piatã, estrada PiatãAbaíra, ca. $3 \mathrm{~km}$ da cidade, $13^{\circ} 12^{\prime} \mathrm{S}, 41^{\circ} 46^{\prime} \mathrm{W}, 1250 \mathrm{~m}, 14$ ago. 1992 (fl., fr.), W. Ganev 857 (CTES, HUEFS, K-foto, SPF); Rio de

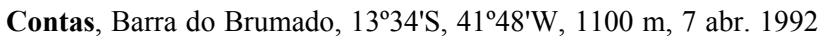
(fl.), G. Hatschbach et al. $56813 b$ (CTES).

Reconhecida pelas folhas geralmente pequenas com margens crenadas, agrupadas no ápice dos ramos e flores de corola amarela. No indumento, podem ser facilmente observados os tricomas glandulares setiformes de base rígida e esbranquiçada, exclusivos desta espécie. Assemelha-se vegetativamente a $P$. nanuzae, a qual se diferencia pelos entrenós geralmente mais longos e maior quantidade de flores na inflorescência, além do indumento com tricomas glandulares setiformes de base hialina.

1.12. Piriqueta duarteana (Cambess.) Urb., Jahrb. Königl. Bot. Gart. Berlin 2: 66. 1883.

Figuras 3A-C e 21; Arbo (1995: fig. 56A-I); Rocha \& Moreira (2014: fotos 9-12).

Arbustos 0,15-1 m alt.; caules esparso-pilosos ou tomentoso-hirsutos, tricomas tectores simples, estrelado-porrectos dourados e glandulares setiformes. Estípulas 0,2-0,5 mm compr. Folhas com pecíolo 1$20 \mathrm{~mm}$ compr.; lâmina $0,7-5,5 \times 0,5-3 \mathrm{~cm}$, papirácea, ligeiramente discolor, aplanada ou recurvada, ovada, elíptica a largo-obovada, base atenuada, cuneada ou arredondada, ápice agudo a obtuso, margens serreadocrenadas a sinuosas, ligeiramente revolutas; face adaxial denso-pilosa, tomentoso-hirsuta, às vezes velutina, não bulada, nervuras impressas, face abaxial tomentosa, nervuras proeminentes. Inflorescências uniforas, solitárias; pedúnculo 2-8(-15) mm compr.; bractéolas reduzidas a um tufo de tricomas, excepcionalmente ca. $3 \mathrm{~mm}$ compr. Flores heterostilas; pedicelo 1-10 $\mathrm{mm}$ compr. Cálice 6-15 $\mathrm{mm}$ compr., externamente tomentoso-hirsuto, ferrugíneo. Corola 12,5 cm compr., salmão a rosa-clara, base das pétalas amarelo-clara. Filetes 5-8 $\mathrm{mm}$ compr. em flores brevistilas, 3-4 $\mathrm{mm}$ compr. em flores longistilas, glabros; anteras 1,5-3 mm compr. Ovário 1,5-3 mm compr.; estiletes 1,2-2,5 $\mathrm{mm}$ compr. em flores brevistilas, 5-7 $\mathrm{mm}$ compr. em flores longistilas, glabros; estigmas penicelados. Cápsulas 7-11 mm diâm.; epicarpo tuberculado, esparso-hirsuto, tricomas glandulares setiformes de base castanho-escura. Sementes 2,2-3,2 × 0,8-1,3 mm, obovoides, retas ou ligeiramente curvas; epiderme papilosa.

Ocorre no Centro-Oeste (Goiás e Mato Grosso), Nordeste (exceto Paraíba), Norte (Pará e Tocantins) e Sudeste (Minas Gerais) do Brasil (Arbo 2015). A9, B6, B7, C4, C5, C6, C7, C/B8, C9, D2, D4, D5, D6, D7, 
D8/9, D10, E4, E5, E6, E9, F4, F5, F6, G3, G4, G5, G6: caatingas, cerrados e campos rupestres. Espécie ruderal, associa-se aos mais diversos ambientes, em áreas abertas, terrenos baldios, margens de rodovias e trilhas, às vezes locais que sofreram ação do fogo ou mesmo em zonas urbanas. Cresce entre rochas, ou substratos arenosos, argilosos a rochosos, em altitudes de 250-1450 m. Apresenta flores e frutos durante todo o ano.

Material selecionado - Abaíra, Catolés, estrada para Cachoeira do Patrício, 13¹7'07"S, 4143'19"W, 26 mar. 2005 (fl., fr.), M.L. Guedes et al. 11549 (ALCB, MBM); Barra, Ibiraba, Icatu, $37 \mathrm{~km} \mathrm{~N}$ de Barra, 1047'18"S, 4249'17"W, 430 m, 19 maio 2010 (fl., fr.), L.P. Queiroz et al. 14676 (HUEFS, IPA); Bom Jesus da Lapa, ca $10 \mathrm{~km}$ E na estrada para Morrão, entrando a ca. $14 \mathrm{~km}$ norte da cidade na

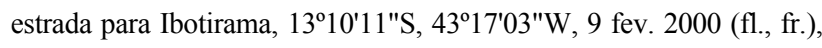
L.P. Queiroz et al. 5778 (ALCB, CTES, HRB, HUEFS); Brumado, $10 \mathrm{~km}$ a W de Brumado, estrada para Caetité, $14^{\circ} 11^{\prime} \mathrm{S}, 41^{\circ} 46^{\prime} \mathrm{W}, 21$ jan. 1997 (fl., fr.), M.M. Arbo et al. 7613 (CEPEC, CTES, K-foto, RB); Caetité, $18 \mathrm{~km}$ antes da cidade, estrada saindo de Brejinho das Ametistas, 14'15'34"S, 42³1'15"W, 27 abr. 2013 (fl., fr.), L. Rocha \& P. Gomes 424 (CTES, HUEFS, RB); Campo Formoso, Comisa, Propriedade da Bayer, Cachoeira do Buraquinho, 10 $10^{\circ} 32^{\prime \prime} \mathrm{S}$, 40¹9'15"W, 21 out. 1991 (fl., fr.), N.L. Menezes et al. 1280 (SPF); Carinhanha, Médio São Francisco, a $1 \mathrm{~km}$ do rio Carinhanha, 14¹8'46"S, 4348'34"W, 478 m, 29 dez. 2007 (fl., fr.), M.L. Guedes \& F.S. Gomes 14112 (ALCB, HUEFS); Casa Nova, sítio Recanto, 09³6'49"S, 4116'44"W, 404 m, 22 mar. 2008 (fl., fr.), U.S. Pesqueira 69 (CTES, HVASF); Feira da Mata, Médio São Francisco, próximo à margem do rio Carinhanha, $14^{\circ} 13^{\prime} 54^{\prime \prime} \mathrm{S}$,

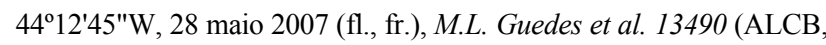
HUEFS); Formosa do Rio Preto, fazenda Estrondo, $2 \mathrm{~km}$ da ponte do rio Riachão em direção à sede da fazenda, $11^{\circ} 07^{\prime} 07^{\prime} \mathrm{S}, 45^{\circ} 29^{\prime} 36^{\prime} \mathrm{W}$, 520 m, 12 nov. 1997 (fl., fr.), M.A. Silva et al. 3584 (CTES, IBGE); Gentio do Ouro, entrando à direita na estrada para Gentio do Ouro, ca. $2 \mathrm{~km}$ da comunidade de Cotovelo, $11^{\circ} 07^{\prime} 45^{\prime \prime} \mathrm{S}, 42^{\circ} 44^{\prime} 19^{\prime \prime} \mathrm{W}, 405$ m, 27 maio 2009 (fl., fr.), D. Araújo et al. 685 (CTES, HVASF, IPA); Itaparica, Complexo Itaparica, Reserva Legal de Jusante, 12 $2^{\circ} 3^{\prime} 16^{\prime \prime S}$, 38 40'44"W, 333 m, 15 jun. 2007 (bot.), M. Oliveira et al. 2848

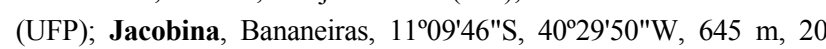
abr. 2009 (fl., fr.), M.L. Guedes et al. 15007 (ALCB); Jandaíra, Mangue Seco, $11^{\circ} 27^{\prime} \mathrm{S}, 37^{\circ} 23^{\prime} \mathrm{W}, 2$ abr. 1998 (fl., fr.), M.C. Ferreira 151 (HRB); Jeremoabo, $10^{\circ} 13^{\prime} \mathrm{S}, 38^{\circ} 30^{\prime} \mathrm{W}, 29$ out. 1981 (fl., fr.), R.P. Orlandi 566 (HRB); Juazeiro, estrada para a cidade, $09^{\circ} 24^{\prime} \mathrm{S}$, 40³0'W, 13 jun. 2009 (fl., fr.), M.L. Guedes et al. 16261 (ALCB); Lençóis, estrada para Cercado, Riacho de Mel, $12^{\circ} 23^{\circ} 27^{\prime} \mathrm{S}$,

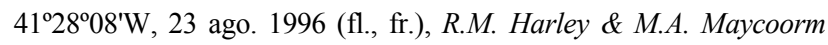
PCD 3771 (ALCB, CTES, HRB, HUEFS, K-foto, SPF); Lícinio de Almeida, Serra do Salto, ca. $1 \mathrm{~km}$ do Povoado Riacho Fundo,

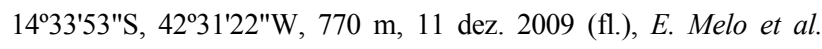
7470 (ALCB, HUEFS); Morpará, estrada para a torre, $2 \mathrm{~km}, 11^{\circ} 33^{\prime} \mathrm{S}$, 431'ㄴ, 24 jan. 2001 (fl., fr.), M.L. Guedes \& D. Paulo Filho 7872 (ALCB, CEPEC, HRB, HUEFS); Morro do Chapéu, Boca do Cedro, margem direita da BA-052, para Utinga, $11^{\circ} 55^{\prime} \mathrm{S}, 41^{\circ} 15^{\prime} \mathrm{W}, 28$ jan. 2013 (fl., fr.), L. Rocha \& B.S. Gregório 386 (HUEFS, RB); Mundo Novo, $11^{\circ} 53^{\prime} 56^{\prime}$ S, 402'ㄴ' $11^{\prime} \mathrm{W}, 26$ ago. 1980 (fl., fr.), R. Orlandi 258 (CEPEC, RB); Murici, $14 \mathrm{~km}$ da antiga rodovia para Nova Viçosa, 10³2'20"S, 4329'28"W, 27 abr. 1973 (fl., fr.), R.S. Pinheiro 2139 (CEPEC, CTES); Oliveira dos Brejinhos, Serra da Água Quente, 12¹9'01"S, 4253'45"W, 16 abr. 1999 (fl., fr.), R.C. Forzza et al. 1263
(CEPEC, NY-foto, SPF); Palmeiras, $10 \mathrm{~km}$ de Palmeiras, estrada

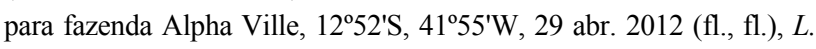
Rocha \& I. Souza 374 (HUEFS); Paratinga, Chapadão de Cima, 1241'27"S, 4311'02"W, 16 mar. 1998 (fl., fr.), G. Hatschbach et al. 67823 (MBM); Piatã, ca. $16 \mathrm{~km}$ da cidade, 130' $\mathrm{S}, 41^{\circ} 48^{\prime} \mathrm{W}, 15 \mathrm{fev}$. 1987 (fl., fr.), R.M. Harley et al. 24265 (CTES, K-foto, SPF); Pilão Arcado, estrada para Brejo do Zacarias (Brejinho), 1000'09"S, 42³0'35"W, 10 nov. 2005 (fl., fr.), A.A. Conceição et al. 1588 (CTES, HUEFS); Remanso, Baixo-Médio São Francisco, ponto $\mathrm{n}^{\circ}$, 09 $32^{\prime} 02^{\prime \prime S}, 41^{\circ} 58^{\prime} 48^{\prime \prime W}, 385$ m, 23 set. 2009 (fl., fr.), M.L. Guedes et al. 16048 (ALCB, HUEFS); Rio de Contas, margem da barragem da

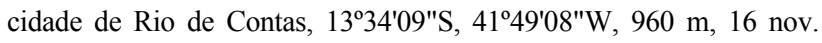
1996 (fl., fr.), H.P. Bautista et al. PCD 4380 (HUEFS); Rodelas, dunas em volta do rio, $08^{\circ} 51^{\prime} 03^{\prime \prime} \mathrm{S}, 38^{\circ} 45^{\prime} 21^{\prime \prime} \mathrm{W}, 280 \mathrm{~m}, 25 \mathrm{fev} .1988$ (fl., fr.), R.P. Orlandi 843 (HRB, RB); Saúde, Serra da Saúde, $10^{\circ} 57^{\prime} \mathrm{S}, 40^{\circ} 27^{\prime} \mathrm{W}, 3$ set. 1981 (fl., fr.), J.D.C. Arouck-Ferreira 88 (CTES, HRB); Senhor do Bonfim, serra do Barro Amarelo, 10³2'36"S, 40¹9'06"W, 900 m, 28 out. 2005 (fl., fr.), S.F. Conceição et al. 318 (HUEFS); Sento Sé, Riacho do Alegre, a $350 \mathrm{~m}$ do povoado Alegre, em direção a nascente, 10¹9'37"S, 41'27'13"W, 1090 m, 3 maio 2012 (fl., fr.), N.M.P. Braga \& R.P. Salomão 58 (CTES,

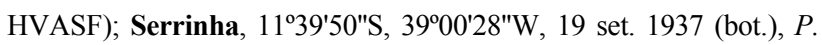
Silva s.n. (SP 39350); Tucano, Buraco do Vento, 1057'46"S, 38 47'13"W, 9 nov. 2010 (fl., fr.), J. Cordeiro et al. 3835 (MBM); Umburanas, Serra do Curral Feio, Cachoeirinha, a beira do rio Tabuleiro, ca. $10 \mathrm{~km} \mathrm{NE}$ de Delfino, 10²43'58"S, 4119'33"W, 10001200 m, 12 abr. 1999 (fl., fr.), L.P. Queiroz et al. 5456 (CTES, HUEFS); Xique-Xique, dunas do rio São Francisco, 1047'16"S, 42 46 '22"W, 548 m, 23 jun. 1996 (fl., fr.), A.M. Giulietti et al. PCD 2962 (ALCB, CEPEC, HST, HUEFS, SPF).

Piriqueta duarteana forma um complexo de espécies similares e com flores geralmente solitárias, de corola salmão a rosada, integrado por nove espécies: $P$. araguaiana Arbo, P. carnea, P. guianensis, $P$. hapala Arbo, P. grandifolia (Urb.) Arbo, $P$. mesoamericana Arbo, $P$. undulata Urb., $P$. venezuelana Arbo e P. tamberliki Urb. (Arbo 1995). Destas, apenas $P$. carnea e $P$. guianensis ocorrem na Bahia; a primeira se diferencia pelas folhas com pecíolos longos, pedúnculos curtos e estigmas pseudocapitados, e a segunda se diferencia pelos pedúnculos geralmente longos e epicarpo com tricomas glandulares setiformes de base hialina, além das folhas floríferas diminuindo em direção ao ápice dos ramos.

Os carateres mais importantes para o reconhecimento de $P$. duarteana são os pedúnculos geralmente curtos e epicarpo com tricomas glandulares setiformes de base castanho-escura. Arbo (1995) considerou duas variedades para a espécie: $P$. duarteana var. duarteana e $P$. duarteana var. ulei Urb., ambas com ocorrência na Bahia. São diferenciadas principalmente pelo indumento: a variedade típica se caracteriza pelo indumento viscoso, composto por abundantes tricomas glandulares setiformes, simples e estrelado-porrectos de raios mais curtos, enquanto que $P$. duarteana var. ulei possui indumento híspido, ferrugíneo, não viscoso, composto por abundantes tricomas estrelado-porrectos, de raios longos, além de simples e glandulares setiformes em menor quantidade, mais curtos. 
1.13. Piriqueta flammea (Suess.) Arbo, Bonplandia 5(14): 121. 1981.

Figuras 21; Arbo (1995: fig. 29A-D).

Arbustos $0,4-1 \mathrm{~m}$ alt.; caules tomentosos a esparso-pilosos, tricomas tectores simples, estreladoporrectos e glandulares setiformes, marrom-dourados. Estípulas até ca. $0,5 \mathrm{~mm}$ compr. Folhas com pecíolo 1,5-6 mm compr.; lâmina 1,3-6 × 1,1-4 cm, subcoriácea, fortemente discolor, aplanada, ovada, elíptica a largo-elíptica, base arredondada, ápice obtuso, margens crenadas, revolutas; face adaxial denso-pilosa, bulada, nervuras profundamente impressas, face abaxial tomentoso-velutina, nervuras proeminentes. Inflorescências em cincinos 3-6-floros; pedúnculo 1-6 cm compr.; bractéolas $0,5-1,5 \mathrm{~mm}$ compr., linear-triangulares. Flores heterostilas; pedicelo 4-8 $\mathrm{mm}$ compr. Cálice $8-12 \mathrm{~mm}$ compr., externamente tomentoso-hirsuto, marrom-dourado. Corola 1,4-2 cm compr., laranja-avermelhada a vermelha. Filetes 6,5-7 $\mathrm{mm}$ compr. em flores brevistilas, 4-6 $\mathrm{mm}$ compr. em flores longistilas, glabros; anteras 1,2-1,5 mm compr. Ovário 1,5-2 mm compr.; estiletes 1,7-2,5 $\mathrm{mm}$ compr. em flores brevistilas, 5-7 $\mathrm{mm}$ compr. em flores longistilas, glabros; estigmas pseudocapitados. Cápsulas 6-9 mm diâm.; epicarpo liso a tenuamente-verrucoso, hirsuto. Sementes $2,2-2,7 \times 1-1,2 \mathrm{~mm}$, obovoides, retas; epiderme papilosa.

Rara, a maioria dos exemplares provém do Pico das Almas, no município de Rio de Contas (Arbo 1995; Arbo \& Giulietti 2009). F6: carrascos e campos rupestres. Cresce entre afloramentos rochosos, em altitudes de 1200-1800 m. Apresenta flores e frutos durante a maior parte do ano.

Material selecionado - Piatã, estrada Piatã-Abaíra, 4 km após

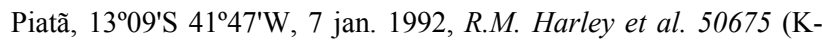
foto); Rio de Contas, trilha para o Pico das Almas, acima do Campo do Queiroz, 133ำ $08^{\circ} \mathrm{S}, 41^{\circ} 57^{\prime} 00^{\prime \prime W}, 22$ jul. 2007 (fl., fr.), C. van den Berg 1871 (HUEFS).

Pode ser reconhecida pela corola vermelhoalaranjada a vermelha, mesmo quando seca, e face adaxial das folha geralmente castanho-escura quando seca, com nervuras profundamente impressas. Além disso, as sementes apresentam uma depressão puntiforme em cada aréola do retículo. Assemelha-se a $P$. crenata e $P$. sarae; a primeira se diferencia pelas inflorescência geralmente com menos flores e corola amarela, com ocorrência restrita ao cerrado de Morro do Chapéu; a segunda se diferencia pelas folhas cartáceas, ovadas a cordadas, concolores, recurvadas, com indumento esparso.

1.14. Piriqueta guianensis N.E.Br., Trans. Linn. Soc. London, Bot. ser. 2, 6: 30. 1901.

Figuras 3D, E e 22; Arbo (1995: fig. 52F-I) ; Rocha \& Moreira (2014: fotos 13 e 14).

Subarbustos $0,2-1 \mathrm{~m}$ alt.; caules denso ou esparsopilosos, tricomas tectores simples, estrelado-porrectos marrom-dourados e glandulares setiformes. Estípulas rudimentares. Folhas com pecíolo até ca. $1 \mathrm{~cm}$ compr.; lâmina (3-)8-55 × (2-)4-25 $\mathrm{mm}$, cartácea, ligeiramente discolor, aplanada a recurvada, ovada, elíptica, estreito-elíptica, raro obovada, base cuneada ou arredondada, ápice agudo ou obtuso, margens serreado-crenadas a sinuosas, planas; face adaxial tomentosa, não bulada, nervuras impressas, face abaxial tomentoso-velutina, nervuras proeminentes. Inflorescências unifloras; pedúnculo (4-)7-20 $\mathrm{mm}$ compr.; bractéolas rudimentares. Flores heterostilas; pedicelo (2-)5-8 $\mathrm{mm}$ compr. Cálice 6-12 $\mathrm{mm}$ compr., externamente tomentoso, ferrugíneo. Corola 1,3-2,5 cm compr., salmão a rosa, base das pétalas amarela a vinácea. Filetes $6-7 \mathrm{~mm}$ compr. em flores brevistilas, 2,5-3,5 $\mathrm{mm}$ compr. em flores longistilas, glabros; anteras 1,2-2 $\mathrm{mm}$ compr. Ovário 1,3-2 $\mathrm{mm}$ compr.; estiletes 2-2,5 $\mathrm{mm}$ compr. em flores brevistilas, 4,5-5 $\mathrm{mm}$ compr. em flores longistilas, glabros a esparsopilosos; estigmas penicelados. Cápsulas $4-8 \mathrm{~mm}$ diâm.; epicarpo granuloso, hirsuto, tricomas glandulares setiformes de base hialina. Sementes 1,7$2,2 \times 0,8-1 \mathrm{~mm}$, estreito-obovoides, retas a ligeiramente curvas; epiderme papilosa.

Ocorre de forma disjunta, na Guiana, Norte (Roraima) e Nordeste do Brasil (Alagoas, Bahia, Ceará, Paraíba, Pernambuco, Piauí, Rio Grande do Norte, Sergipe). B7, B8, B9, C8/9, D4, E6, E8/9, E10, F6: caatingas e cerrados. Ruderal, habita áreas abertas, em margens de rodovias ou trilhas, comum em zonas urbanas e pastos. Cresce entre rochas, em substratos arenosos, argilosos ou rochosos, em altitudes de 300$660 \mathrm{~m}$. Apresenta flores e frutos durante o ano inteiro.

Material selecionado - Canudos, estrada Biodiversitas, 09 $54^{\prime} 35^{\prime \prime} \mathrm{S}, 39^{\circ} 00^{\prime} 48^{\prime \prime} \mathrm{W}, 437 \mathrm{~m}, 22$ maio 2003 (fl., fr.), A.A. Oliveira et al. 192 (HUEFS); Conde, estrada para o município, 27 jul. 1990 (fl., fr.), M.C. Ferreira 265 (HRB); Curaçá, fazenda Barra Grande, 0904'S, 3957'W, 10 ago. 1983 (fl., fr.), S.B. Silva \& G.C.P. Pinto 272 (CTES, HRB, K-foto); Entre Rios, no fundo do povoado, $12^{\circ} 14^{\prime} 19^{\prime \prime} \mathrm{S}, 37^{\circ} 46^{\prime} 53^{\prime \prime} \mathrm{W}, 28$ jan. 2011 (fl., fr.), F.S. Gomes 861 (ALCB); Euclides da Cunha, $10^{\circ} 31^{\prime} \mathrm{S}, 39^{\circ} 01^{\prime} \mathrm{W}, 8$ jul. 1951 (fl., fr.), O.P. Travassos 191 (RB); Feira de Santana, $12^{\circ} 15^{\prime} 00^{\prime \prime S}, 38^{\circ} 58^{\prime} 00^{\prime \prime W}, 28$ dez. 2010 (fl., fr.), I.M. Souza 27 (HUEFS); Glória, BA-210 sentido Glória-Rodelas, 09¹3'53"S, 38 24'29"W, 310 m, 5 maio 2007 (fl., fr.), A.S. Conceição et al. 954 (HUEFS); Juazeiro, Baixo Médio São Francisco, estrada para Juazeiro, 09 $24^{\prime} \mathrm{S}, 40^{\circ} 30^{\prime} \mathrm{W}, 11$ jun. 2009 (fl., fr.), M.L. Guedes et al. 16243 (ALCB, HST); Livramento de Nossa Senhora, 17,5 km da cidade, na estrada para Lagoa Nova, $13^{\circ} 48^{\prime} \mathrm{S}, 41^{\circ} 47^{\prime} \mathrm{W}, 505 \mathrm{~m}, 31$ jan. 2005 (fl., fr.), J. Paula-Souza et al. 5166 (CTES, ESA, MBM); Mata de São João, Sauipe, 12³1'48"S, 38º'17'56"W, 9 jun. 1996 (fl., fr.), R. Soeiro 07-96 (CTES, HRB); Morpará, $20 \mathrm{~km}$ de Morpará, Lagoa redonda, $11^{\circ} 33^{\prime} \mathrm{S}, 43^{\circ} 16^{\prime} \mathrm{W}, 23$ jan. 2001 (fl., fr.), M.L. Guedes \& D. Paulo-Filho 7852 (ALCB, CEPEC, HRB, HUEFS); Muritiba, 12²37'33"S, 3859'24"W, 12 out. 1956 (fl., fr.), R.P. Lordêlo 56-600 (ALCB); Palmeiras, Vale do Cerrado, $12^{\circ} 25^{\prime} 49^{\prime \prime} \mathrm{S}, 41^{\circ} 27^{\prime} 11^{\prime \prime W}, 657$ m, 5 abr. 2004 (fl., fr.), P.D. Carvalho et al. 49 (HUEFS); Paulo Afonso, Raso da Catarina, Cachimbo, 09³9'12"S, 38³2'14"W, $595 \mathrm{~m}, 10$ ago. 2005 (fl., fr.), E.B. Miranda et al. 821 (HUEFS, SP). 
Pode ser reconhecida pelas flores com pedúnculos longos e a corola salmão ou rosa e sementes com uma depressão puntiforme em cada aréola. Além das folhas floríferas pequenas, bractiformes no ápice dos ramos. Apresenta indumento variável: há plantas muito viscosas, escurecidas quando secas, com tricomas glandulares setiformes abundantes, e outras hirsutas a tomentoso-velutinas, verde-oliva quando secas, com tricomas estrelado-porrectos de raio central curto ou longo. Suas flores são visitadas por besouros, borboletas e pequenas aranhas verdes. Assemeha-se a $P$. duarteana, a qual se diferencia pelos pedúnculos florais geralmente mais curtos e epicarpo com tricomas glandulares setiformes de base castanho-escura.

Arbo (1995) considerou duas subespécies: $P$. guianensis subsp. guianensis e P. guianensis subsp. elongata (Urb. \& Rolfe) Arbo; apenas a segunda com ocorrência na Bahia. A subespécie típica apresenta nervuras secundárias com ângulo de divergência de $22-45^{\circ}$, estiletes pilosos e sementes de 1,5-1,8 $\mathrm{mm}$ compr., ocorrendo apenas nas Guianas e Roraima (Arbo 1995). A subespécie $P$. guianensis subsp. elongata se diferencia pelas nervuras com ângulo de divergência de $18-30^{\circ}$, estiletes glabros a esparsopilosos e sementes maiores, 1,9-2,3 mm compr., sendo amplamente distribuída no Nordeste brasileiro.

1.15. Piriqueta nanuzae Arbo, Fl. Neotrop. Monogr. 67: 44. 1995.

Figuras 22; Arbo (1995: fig. 25A-D); Rocha \& Moreira (2014: foto 15).

Arbustos ou subarbustos 0,6-1,3 m alt.; caules jovens tomentosos, tricomas tectores simples, estrelado-porrectos e glandulares setiformes, marromdourados. Estípulas ausentes. Folhas com pecíolo 2,5-11(-18) mm compr.; lâmina 0,8-3,9(-6,3) × 0,5$2(-3,6) \mathrm{cm}$, papirácea, discolor, recurvada a ligeiramente aplanada, ovada a estreito-ovada, raro elíptica, base arredondada ou cuneada, raro cordada, ápice agudo a obtuso, margens crenadas, revolutas; face adaxial denso-pilosa, bulada, nervuras impressas, face abaxial tomentosa, nervuras proeminentes. Inflorescências em cincinos 2-10-floros; pedúnculo 3-20 mm compr.; bractéolas 0,5-2 $\mathrm{mm}$ compr., linear-triangulares. Flores heterostilas; pedicelo 1,7-4 mm compr. Cálice 4-8 mm compr., externamente tomentoso, ferrugíneo. Corola 6-12 $\mathrm{mm}$ compr., amarelo-viva a amarelo-alaranjada. Filetes 3-5 $\mathrm{mm}$ compr. em flores brevistilas, 2-3 $\mathrm{mm}$ compr. em flores longistilas, glabros; anteras 0,7-1 mm compr. Ovário 0,7-1,5 $\mathrm{mm}$ compr.; estiletes 1-1,3 $\mathrm{mm}$ compr. em flores brevistilas, 2,5-3,5 mm compr. em flores longistilas, glabros; estigmas penicelados. Cápsulas 3-6 mm diâm.; epicarpo liso ou tenuamente verrucoso, esparso-piloso. Sementes 2,2-2,8 × 1-1,2 $\mathrm{mm}$, estreito-obovoides, ligeiramente curvas; epiderme papilosa.

Rara, endêmica da porção central da Chapada Diamantina, na Bahia (Arbo 1995; Arbo \& Giulietti
2009). E6, F6: campos rupestres. Habita áreas abertas, geralmente entre rochas, às vezes na margem de rodovias ou trilhas, em substratos arenosos ou rochosos, em altitudes de até $760 \mathrm{~m}$. Apresenta flores e frutos durante a maior parte do ano.

Material selecionado - Andaraí, $12^{\circ} 25^{\prime} \mathrm{S}, 41^{\circ} 18^{\prime} \mathrm{W}, 22$ jan. 1995 (fl., fr.), L.P. Félix et al. 6780 (HST); Ibicoara, Pau Ferrada (Batava) Baixão, 1318'30"S, 4116'00"W, 12 jan. 2005 (fl., fr.), $R$. Funch 465 (HUEFS); Itaetê, Chapadinha, 12 ${ }^{\circ} 33^{\prime} 10^{\prime \prime} \mathrm{S}, 41^{\circ} 23^{\prime} 34^{\prime \prime} \mathrm{W}$, 21 fev. 2004 (fl., fr.), R. Funch 129 (HUEFS); Lençóis, próximo ao

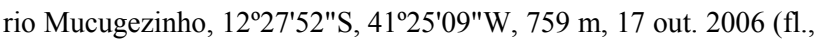
fr.), S.P.S. Neves et al. 133 (HUEFS); Mucugê, $4 \mathrm{~km} \mathrm{~N}$ da cidade,

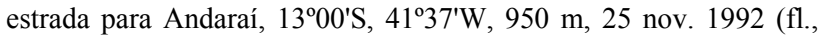
fr.), M.M. Arbo et al. 5767 (holótipo SPF, isótipos CTES, G-foto, HUEFS, IPA, K-foto, MBM, MO-foto, P-foto, RB, SI-foto, SP, SPF, UB, US-foto, YUTO-foto); ib., morro do cruzeiro, $13^{\circ} 00^{\prime} \mathrm{S}$, $41^{\circ} 37^{\prime} \mathrm{W}, 18$ jan. 2012 (fl., fl.), L. Rocha et al. 357 (CTES, HUEFS, RB, SPF); Palmeiras, 12 $27^{\prime} \mathrm{S}, 4^{\circ} 27^{\prime} \mathrm{W}, 26$ ago. 2005 (fl., fr.), G. Costa et al. 30 (HUEFS).

Pode ser reconhecida pelas folhas viscosas, inflorescências com flores de corola geralmente amarelo-viva, frutos lisos a tenuamente verrucosos e sementes com 1 ou 2 depressões puntiformes em cada aréola. Em Funch 465, as flores são descritas como brancas, uma coloração incomum nesta espécie. Assemelha-se a $P$. crenata, que se diferencia pelas folhas com base atenuada a cuneada, inflorescência com menos flores e pedicelos mais longos.

1.16. Piriqueta plicata Urb., Jahrb. Königl. Bot. Gart. Berlin 2: 65. 1883.

Figuras 23; Arbo (1995: 42A-G).

Subarbustos 15-60 cm alt.; caules tomentosos, tricomas tectores estrelados, estrelado-porrectos e glandulares setiformes amarelo-dourados. Estípulas rudimentares. Folhas com pecíolo 0,5-4 mm compr.; lâmina $2-5 \times 0,2-0,6 \mathrm{~cm}$, cartácea, ligeiramente discolor, aplanada ou recurvada, linear ou elíptica, base atenuada a cuneada, ápice agudo, margens inteiras ou discretamente serrilhadas, planas; face adaxial tomentosa, não bulada, apenas a nervura principal impressa, face abaxial tomentosa, nervuras proeminentes. Inflorescências unifloras; pedúnculo 3$8 \mathrm{~mm}$ compr.; bractéolas ausentes. Flores heterostilas; pedicelo 2,5-5 $\mathrm{mm}$ compr. Cálice 6-8 $\mathrm{mm}$ compr., externamente tomentoso, marrom-dourado. Corola 8$13 \mathrm{~mm}$ compr., amarelo-clara. Filetes 4-6 mm compr. em flores brevistilas, 3-3,5 $\mathrm{mm}$ compr. em flores longistilas, glabros; anteras 1-1,5 mm compr. Ovário 1,5-2 mm compr.; estiletes 1-1,5 mm compr. em flores brevistilas, 3,5-5 $\mathrm{mm}$ compr. em flores longistilas, glabros; estigmas penicelados. Cápsulas 3-4,5 $\mathrm{mm}$ diâm.; epicarpo tuberculado, tomentoso-hirsuto. Sementes 2-2,5 $\times$ 0,9-1,2 $\mathrm{mm}$, obovoides, ligeiramente curvas; epiderme papilosa.

Ocorre no Maranhão, Piauí e Bahia (Arbo 2015). O material-tipo corresponde ao único registro conhecido para o estado da Bahia, coletado no município de Queimadas, com flores e frutos no mês de abril. 

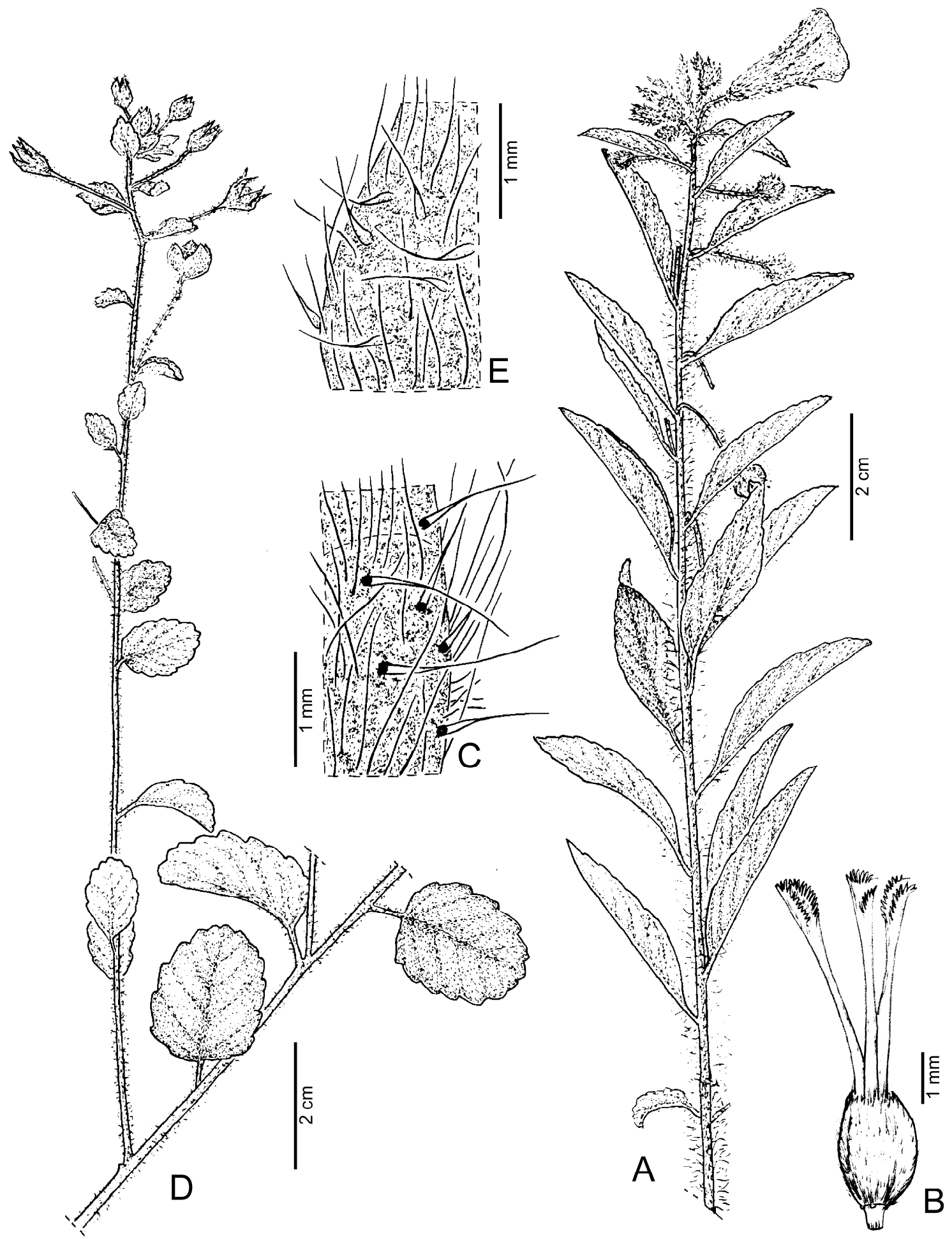

Figura 3. A-C. Piriqueta duarteana: A- ramo reprodutivo; B- gineceu; C- superfície do epicarpo evidenciando tricomas glandulares setiformes de base escura (Queiroz 5778). D, E. P. guianensis: D- ramo reprodutivo; E- epicarpo evidenciando tricomas glandulares setiformes de base hialina (Crepaldi 1) (A, C-E por Liliana Gomes).

Material examinado - "In sylvis catingas ad San Antonio das Queimadas", aprox. $10^{\circ} 58^{\prime} \mathrm{S}, 39^{\circ} 37^{\prime} \mathrm{W}$, abr. (fl., fr.), C.F.P. von Martius s.n. (holótipo M 113098-foto).

Material adicional examinado - BRASIL. PIAUÍ: Castelo do Piauí, Percurso da Raposa, 05 $13^{\prime} \mathrm{S}, 41^{\circ} 41^{\prime} \mathrm{W}, 200$ m, 14 abr. 2004 (fl., fr.), J.M. Costa et al. 173 (HUEFS).
Pode ser reconhecida pelas folhas elípticas a lineares, com margens inteiras a serrilhadas; a face adaxial é marrom-dourada escura a verde-ferrugínea quando seca, somente a nervura principal é impressa, as nervuras secundárias são discretas, evidentes apenas na face abaxial. As sementes apresentam uma 
depressão puntiforme em cada aréola do retículo. Piriqueta plicata se assemelha a $P$. rosea Urb., ocorrente em Goiás, São Paulo e Mato Grosso, a qual se diferencia pelas flores de corola rosada, com pedicelos geralmente longos. O material-tipo apresenta folhas longas, lineares, desprovidas de tricomas glandulares, diferente dos demais espécimes, com folhas menores, elípticas, com tricomas glandulares septiformes; trata-se, contudo, de uma variação da espécie.

\subsection{Piriqueta racemosa (Jacq.) Sweet, Hort. Brit.:} 154. 1826.

Figuras 4A, B e 23; Arbo (1995: fig. 59A-F); Rocha \& Moreira (2014: fotos 16 e 17).

Ervas ou subarbustos 0,3-1 m alt.; caules tomentoso-hirsutos, tricomas tectores simples, estrelados e estrelado-porrectos ferrugíneos. Estípulas rudimentares. Folhas com pecíolo até $1,2(-2) \mathrm{cm}$ compr.; lâmina 0,5-9 × 0,5-6 cm, papirácea, concolor a discolor, ligeiramente recurvada, ovada, largo-ovada, base cuneada, arredondada ou atenuada, ápice agudo, margens simples a duplamente crenadas ou serreadocrenadas, ligeiramente revolutas; face adaxial densopilosa, não bulada, nervuras discretamente impressas, face abaxial tomentoso-velutina, nervuras proeminentes. Inflorescências unifloras, reunidas em racemo terminal alongado; pedúnculo $0,7-1,7(-4) \mathrm{cm}$ compr.; bractéolas ausentes. Flores heterostilas ou homostilas; pedicelo 1-5 $\mathrm{mm}$ compr. Cálice 4,5-9 $\mathrm{mm}$ compr., externamente tomentoso-hirsuto, marromdourado. Corola 7-15 mm compr., creme, amarela a amarelo-alaranjada, base das pétalas amarelo-escura, raro castanho-escura. Filetes 2,5-5 $\mathrm{mm}$ compr., glabros; anteras 1-1,5 mm compr. Ovário 1,5-3 $\mathrm{mm}$ compr.; estiletes 1,7-4 mm compr., glabros; estigmas penicelados. Cápsulas 5-10 mm diâm.; epicarpo liso, esparso-setoso. Sementes 1,7-2 × ca. $1 \mathrm{~mm}$, lunadas; epiderme papilosa, nós do retículo proeminentes.

Apresenta área de distribuição disjunta, ocorre nas Antilhas, Colômbia, Venezuela e Paraguai, além do Velho Mundo, onde provavelmente foi introduzida (Arbo 1995). No Brasil, ocorre no Nordeste (exceto Maranhão) e Sudeste (Espírito Santo, Minas Gerais e Rio de Janeiro) (Arbo 2015). B5, B7, B8/9, C7, C8, C8/9, D6, D7, D8, D10, E6, E7, E8, E9, F7, F/G7, G5, G6: caatingas e restingas. Espécie ruderal, habita áreas abertas, por vezes perturbadas, como terrenos baldios, zonas urbanas, margens de trilhas e rodovias. Cresce sobre substratos arenosos, argilosos ou rochosos, em altitudes até $915 \mathrm{~m}$. Apresenta flores e frutos durante o ano inteiro.

Material selecionado - Aracatu, $20 \mathrm{~km}$ após Anagé, 14'25'40"S, 41 ${ }^{\circ} 27^{\prime} 43^{\prime \prime} \mathrm{W}, 26$ abr. 2013 (fl., fr.), L. Rocha \& P. Gomes 419 (CTES, HUEFS); Aramari, Pasto Cisterna, estrada para Alagoinhas, 1204'55"S, 38²9'56"W, 15 jul. 1981 (fl.), E.L.P.G. Oliveira 386 (CEPEC); Baixa Grande, $1 \mathrm{~km} \mathrm{~N}$ de Baixa Grande, 11 ${ }^{\circ} 57^{\prime} \mathrm{S}, 40^{\circ} 10^{\prime} \mathrm{W}, 12$ abr. 1983 (fl., fr.), A. Krapovickas et al. 38807 (CEN, K-foto, MBM); Brumado, BA-262, $55 \mathrm{~km}$ SE da cidade, estrada para Anajé, 143' $\mathrm{S}, 4^{\circ} 23^{\prime} \mathrm{W}, 600-700$ m, 22 jan. 1997 (fl.), M.M. Arbo et al. 7659 (CEPEC, CTES); Cachoeira, Barragem de Bananeiras, vale dos rios Paraguaçu e Jacuípe, $12^{\circ} 32^{\prime} \mathrm{S}, 39^{\circ} 05^{\prime} \mathrm{W}$, 40-120 m, 1 maio 1980 (fl., fr.), Grupo Pedra do Cavalo 37 (ALCB, CEPEC, HRB, HUEFS, NY-foto, RB); Canudos, Reserva Biológica de Canudos, Biodiversitas, 0956'34"S, 3859'17"W, jan. 2002 (fl., fr.), M.S. Castro \& C.M. Pigozzo s.n. (ALCB 66386); Castro Alves, 12 $2^{\circ} 45^{\prime} \mathrm{S}, 39^{\circ} 26^{\prime} \mathrm{W}, 29$ abr. 1994 (fl., fr.), C.A.L. Carvalho P-008 (CTES, HUEFS); Conde, Poclas-Siribinha,

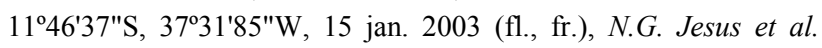
1626 (ALCB, HUEFS); Esplanada, Fazenda do Bu, margem da estrada do Fundão II, 1200'36"S, 3744'00"W, 29 maio 1996 (fl., fr.), T. Jost \& M.C. Ferreira 303 (HRB, MBM); Euclides da Cunha, Nordeste, assentamento Vila Canaã, 10²7'94"S, 38 58'25"W, 13 abr. 2004 (fl., fr.), M.L. Guedes et al. 11171 (ALCB); Feira de Santana, Estrada do Feijão, lado esquerdo, $12^{\circ} 15^{\prime} \mathrm{S}, 38^{\circ} 58^{\prime} \mathrm{W}, 30$ abr. 2012 (fl.), L. Rocha \& I. Souza 375 (CTES, HUEFS); Filadélfia, estrada de Filadélfia para Pindobaçu, a $14 \mathrm{~km}$ da BR-407, 1048'S, 40¹4'W, 300-400 m, 16 jan. 1997 (fl.), M.M. Arbo et al. 7338 (CEPEC, CTES); Iaçu, fazenda Suibra, Morro do Gado Bravo, 12² $43^{\prime} \mathrm{S}, 40^{\circ} 07^{\prime} \mathrm{W}, 14$ mar. 1985 (bot., fr.), L.R. Noblick 3705 (HUEFS); Ipacaetá, fazenda Riachão, serra Orobozinho, ca $1 \mathrm{~km}$ da cidade, $12^{\circ} 20^{\prime} \mathrm{S}, 39^{\circ} 17^{\prime} \mathrm{W}, 14$ ago. 1985 (fl., fr.), L.R. Noblick \& G.C. Lôbo 4301 (HUEFS); Iramaia, fazenda Leopoldina, 133' $\mathrm{S}, 40^{\circ} 43^{\prime} \mathrm{W}, 400 \mathrm{~m}, 4$ abr. 1984 (fl., fr.), L.C. Oliveira-Filho \& J.C.A. Lima 151 (CEPEC, IPA, HRB, RB); Itaberaba, fazenda Itaberaba, Morro de Itiberaba, $12^{\circ} 30^{\prime} 10^{\prime \prime} \mathrm{S}$, $40^{\circ} 04^{\prime} 60^{\prime \prime W}, 210$ m, 4 jun. 2005 (fl., fr.), E. Melo et al. 3883 (HUEFS); Itatim, 1242'43"S, 3941'52"W, 16 mar. 1997 (fl., fr.), V.M. Monteiro et al. 52 (HUEFS); Itiúba, Serra de Itiúba, $1 \mathrm{~km}$ E da cidade, estrada para Cansanção, 1042'S, 39 50'W, 16 jan. 1997 (fl., fr.), M.M. Arbo et al. 7320 (ALCB, CEPEC, CTES, HRB, HUEFS, K-foto, MBM); Jacobina, BR-324, 12 km NW de Jacobina, estrada para Umburanas, $11^{\circ} 06^{\prime} \mathrm{S}, 40^{\circ} 36^{\prime} \mathrm{W}, 17$ jan. 1997 (fl.), M.M. Arbo et al. 7365 (CEPEC, CTES); Jequié, BR-116, $30 \mathrm{~km}$ antes da cidade, 16 $\mathrm{km}$ após entrocamento de Jaguaquara, $13^{\circ} 51^{\prime} 28^{\prime \prime} \mathrm{S}, 40^{\circ} 05^{\prime} 02^{\prime \prime} \mathrm{W}, 25$ abr. 2013 (fl., fr.), L. Rocha \& P. Gomes 410 (HUEFS); Juazeiro, 09²4'50"S, 40³0'10"W, 7 set. 1971 (fl.), A.L. Costa s.n. (ALCB 2837); Lençóis, $3 \mathrm{~km} \mathrm{~N}$ na ligação com a rodovia BR-242, 12³3'46"S, 41²3'24"W, 9 abr. 1992 (fl., fr.), G. Hatschbach et al. 56934 (CEPEC, CTES); Licínio de Almeida, trilha para o Cachoeirão, ao lado da caixa d'água, 14²41'42"S, 42³3'04"W, 915 m, 6 abr. 2013 (fl., fr.), L. Rocha et al. 405 (HUEFS); Livramento de Nossa Senhora, após $19 \mathrm{~km}$ de Livramento do Brumado,

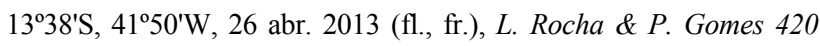
(CTES, HUEFS); Manoel Vitorino, rodovia para Jequié, $14^{\circ} 00^{\prime} \mathrm{S}$, $40^{\circ} 10^{\prime} \mathrm{W}, 300$ m, 9 fev. 1985 (fl.), A. Gentry 49983 (CEPEC); Marcionílio Souza, na estrada para São João, $13^{\circ} 00^{\prime} 10^{\prime \prime S}$, 40³1'51"W, 11 fev. 1997 (fl., fr.), A.M. Giulietti PCD 5500 (ALCB, CEPEC, HRB, HUEFS); Milagres, fazenda São Bento, $12^{\circ} 52^{\prime} 12^{\prime \prime S}$, 39 51'32"W, 4 set. 2010 (fl., fr.), E. Barbosa et al. 2743 (MBM); Monte Santo, 10'26'S, 39 $19^{\circ} \mathrm{W}, 11$ jan. 2006 (fl., fr.), M.L. Guedes et al. 12095 (ALCB); Morro do Chapéu, estrada para o Morrão, $11^{\circ} 33^{\prime} \mathrm{S}, 41^{\circ} 09^{\prime} \mathrm{W}, 22$ out. 2011 (fl., fr.), M.L. Guedes et al. 19300 (ALCB); Nova Itarana, à $1 \mathrm{~km}$ da BR-116, entrada de Nova Itarana, 130' 'S, 4006'W, 4 abr. 2013 (fl., fr.), L. Rocha et al. 390 (ALCB, CTES, HUEFS); Paulo Afonso, 09 $24^{\prime} 28^{\prime \prime} S, 38^{\circ} 13^{\prime} 19^{\prime \prime} \mathrm{W}, 10$ jul. 2005 (fl., fr.), D.V. Braga et al. s.n. (IPA 73971); Pindaí, rodovia

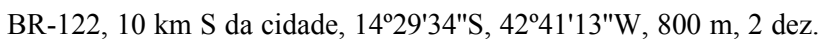


2004 (fl., fr.), G. Hatschbach 78758 (MBM); Pitombaçu, 22 km a W de Itiúba, estrada para Filadélfia, $10^{\circ} 43^{\prime} \mathrm{S}, 40^{\circ} 03^{\prime} \mathrm{W}, 400 \mathrm{~m}, 16$ jan. 1997 (fl., fr.), M.M. Arbo et al. 7327 (CEPEC, CTES); Poções, Bom Jesus da Serra, $14^{\circ} 24^{\prime} \mathrm{S}, 40^{\circ} 31^{\prime} \mathrm{W}, 15$ jan. 2009 (fl., fr.), P.D. Carvalho \& A.A. Conceição 466 (HUEFS); Queimadas, $5 \mathrm{~km}$ a SE de Queimadas, estrada para Serrinha, $11^{\circ} 04^{\prime} \mathrm{S}, 39^{\circ} 35^{\prime} \mathrm{W}, 15$ jan. 1997 (fl., fr.), M.M. Arbo et al. 7271 (CEPEC, CTES); Quijingue, Serra das Candeias, ca. $5 \mathrm{~km}$ a $\mathrm{W}$ do povoado Quixaba do Mandacaru, $10^{\circ} 55^{\prime} 19^{\prime \prime}$, 3904'59"W, 400 m, 8 jul. 2006 (fl., fr.), D. Cardoso \& T.M. Santana 1344 (HUEFS); Retirolândia, estrada para Pedra Grande, 11'29'42"S, 39²5'33"W, 1 nov. 1999 (fl., fr.), R.P. Oliveira et al. 312 (CTES, HUEFS); Salvador, Parque Metropolitano de PItuaçu, 1256'40"S, 38²7'07"W, 28 mar. 1998 (fl., fr.), J. Costa 204 (HRB) Senhor do Bonfim, sítio Cristiana, $10^{\circ} 24^{\prime} 22^{\prime \prime} \mathrm{S}, 40^{\circ} 10^{\prime} 39^{\prime \prime} \mathrm{W}, 19$ abr. 2011 (fl., fr.), J.O. Santos et al. 35 (HUEFS); Sento Sé, Topo do Morro, 09 $51^{\prime} 32^{\prime \prime S}, 42^{\circ} 03^{\prime} 05^{\prime \prime W}, 570$ m, 16 dez. 2007 (fl., fr.), $C$. Correia et al. 357 (HUEFS); Tanquinho, $8 \mathrm{~km}$ a $\mathrm{N}$ de Tanquinho,

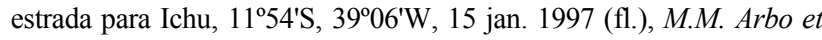
al. 7250 (CEPEC, CTES); Tucano, Serra do Bizamum, 1053'34"S, 38 59'30"W, 303 m, 21 abr. 2005 (fl., fr.), D. Cardoso et al. 483 (HUEFS); Urandi, $7 \mathrm{~km} \mathrm{~N}$ de Urandi, 12 02 'S, 39 $02^{\prime} \mathrm{W}, 20$ nov. 1992 (fl., fr.), M.M. Arbo et al. 5612 (CTES, SPF, UB); Vitória da Conquista, 14 $51^{\prime} 57^{\prime \prime S}, 40^{\circ} 50^{\prime} 20^{\prime \prime} \mathrm{W}, 21$ abr. 1975 (fl., fr.), E.F. Gusmão s.n. (ALCB 19344).

Pode ser reconhecida pelas flores dispostas em um racemo alongado, até $35 \mathrm{~cm}$ compr., com folhas terminais bractiformes ou ausentes, além dos frutos com epicarpo liso e sementes lunadas, com nós do retículo proeminentes e agudos, com uma depressão puntiforme em cada aréola. Apresenta heterostilia trimorfa, podendo haver flores com androceu e gineceu com alturas iguais (flor homostila) ou diferentes (flor heterostila). Suas flores são delicadas, fechando no início (13:00 hs) ou, mais raramente, no fim da tarde. São visitadas por borboletas, besouros e pequenas aranhas verdes. Assemelha-se a $P$. cistoides, que se diferencia pelas flores solitárias, axilares e sementes com nós do retículo não proeminentes.

\subsection{Piriqueta revoluta Arbo, Kew Bull. 54(2): 462.} 1999.

Figuras 23; Arbo (1999: fig. 2A-G).

Subarbustos $50 \mathrm{~cm}$ alt.; caules esparso a densopilosos, tricomas tectores simples, estrelado-porrectos e glandulares setiformes, amarelo-dourados. Estípulas rudimentares. Folhas com pecíolo até ca. $1 \mathrm{~mm}$ compr.; lâmina 4,5-11 × 2-3,5 mm, coriácea, ligeiramente discolor, aplanada, elíptica, base arredondada, ápice agudo, margens inteiras, fortemente revolutas; face adaxial tomentosa, não bulada, apenas a nervura principal impressa, face abaxial tomentosa, nervura principal proeminente. Inflorescências unifloras; pedúnculo 2,5-3,5 mm compr.; bractéolas 0,5-2 mm compr., linear-triangulares ou reduzidas a um tufo de tricomas. Flores heterostilas; pedicelo 2-3 $\mathrm{mm}$ compr. Cálice 7-10 mm compr., externamente tomentoso-hirsuto, marrom-dourado. Corola 1,3-1,7 cm compr., amarela ou amarelo-alaranjada. Filetes ca. $4 \mathrm{~mm}$ compr. em flores longistilas, glabros; anteras ca.
1,8 mm compr. Ovário 2-3 mm compr.; estiletes 2,5-3 $\mathrm{mm}$ compr. em flores longistilas, glabros; estigmas penicelados. Cápsulas imaturas ca. $3 \mathrm{~mm}$ diâm.; epicarpo granuloso, tomentoso-hirsuto. [Sementes desconhecidas]

Rara, endêmica da porção central da Chapada Diamantina, conhecida apenas por dois exemplares (Arbo 1995; Arbo \& Giulietti 2009). F6: campos rupestres. Encontrada em altitudes de até $1400 \mathrm{~m}$, crescendo em substrato arenoso, com flores e frutos nos meses de abril e agosto.

Material examinado - Abaíra, Serra dos Brejões, próximo ao Rio da Água Suja, divisa com Arapiranga, $13^{\circ} 49^{\prime} \mathrm{S}, 41^{\circ} 24^{\prime} \mathrm{W}, 1400$ m, 9 ago. 1993 (fl.), W. Ganev s.n. (holótipo HUEFS 19173); Rio

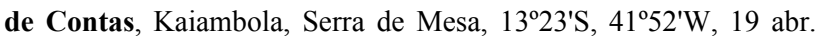
2003 (fl., fr.), A.M. Giulietti et al. 2385 (HUEFS).

Pode ser reconhecida pelas folhas sésseis ou curtopecioladas, elípticas e fortemente revolutas, com apenas a nervura principal impressa na face adaxial. $\mathrm{O}$ formato e a disposição das folhas lembra Turnera revoluta Urb., que se diferencia pelas flores sésseis desprovidas de corona.

1.19. Piriqueta sarae Arbo, Kew Bull. 48: 11. 1993.

Figuras 4C e 24; ; Arbo (1995: fig. 29E-H); Rocha \& Moreira (2014: fotos 18-20).

Subarbustos ou arbustos 0,2-2 m alt.; caules denso-pilosos, tricomas tectores simples e glandulares setiformes, marrom-dourados. Estípulas ausentes. Folhas com pecíolo 3-20 mm compr.; lâmina 0,9-5,5 $\times \quad 0,8-3,7 \mathrm{~cm}$, papirácea, ligeiramente discolor, recurvada, ovada a largo-ovada, base cordada, arredondada a atenuada, ápice agudo ou obtuso, margens duplamente serreado-crenadas, revolutas; face adaxial glabra ou com tricomas esparsos, bulada, nervuras impressas, face abaxial com tricomas concentrados nas nervuras, estas proeminentes. Inflorescências em cincinos 2-6-floros; pedúnculo 1$5 \mathrm{~cm}$ compr.; bractéolas 0,2-4 $\mathrm{mm}$ compr., lineartriangulares. Flores heterostilas; pedicelo $2-7 \mathrm{~mm}$ compr. Cálice 5-10 $\mathrm{mm}$ compr., externamente tomentoso, ferrugíneo. Corola 7-18 mm compr., laranja ou laranja-avermelhada. Filetes 7-8 $\mathrm{mm}$ compr. em flores brevistilas, 4-6 $\mathrm{mm}$ compr. em flores longistilas, glabros; anteras 1,3-2 mm compr. Ovário 1,5-2 mm compr.; estiletes 1,5-3 mm compr. em flores brevistilas, 4-6 $\mathrm{mm}$ compr. em flores longistilas, glabros; estigmas penicelados. Cápsulas 4-10 $\mathrm{mm}$ diâm.; epicarpo liso ou tenuamente verrucoso, esparsopiloso. Sementes 2,5-3,6 × 1-1,5 mm, obovoides, ligeiramente curvas; epiderme papilosa.

Ocorre predominantemente no estado da Bahia, havendo apenas um espécime coletado em Minas Gerais (Arbo 1995, 2015). E5, E6, F6: campos rupestres, cerrados, campos gerais, áreas de transição cerrado/caatinga. Habita áreas de afloramentos rochosos ou margens ribeirinhas, em substratos arenosos, rochosos, às vezes úmidos, em altitudes de 800-1300 m. Apresenta flores e frutos durante a maior parte do ano. 


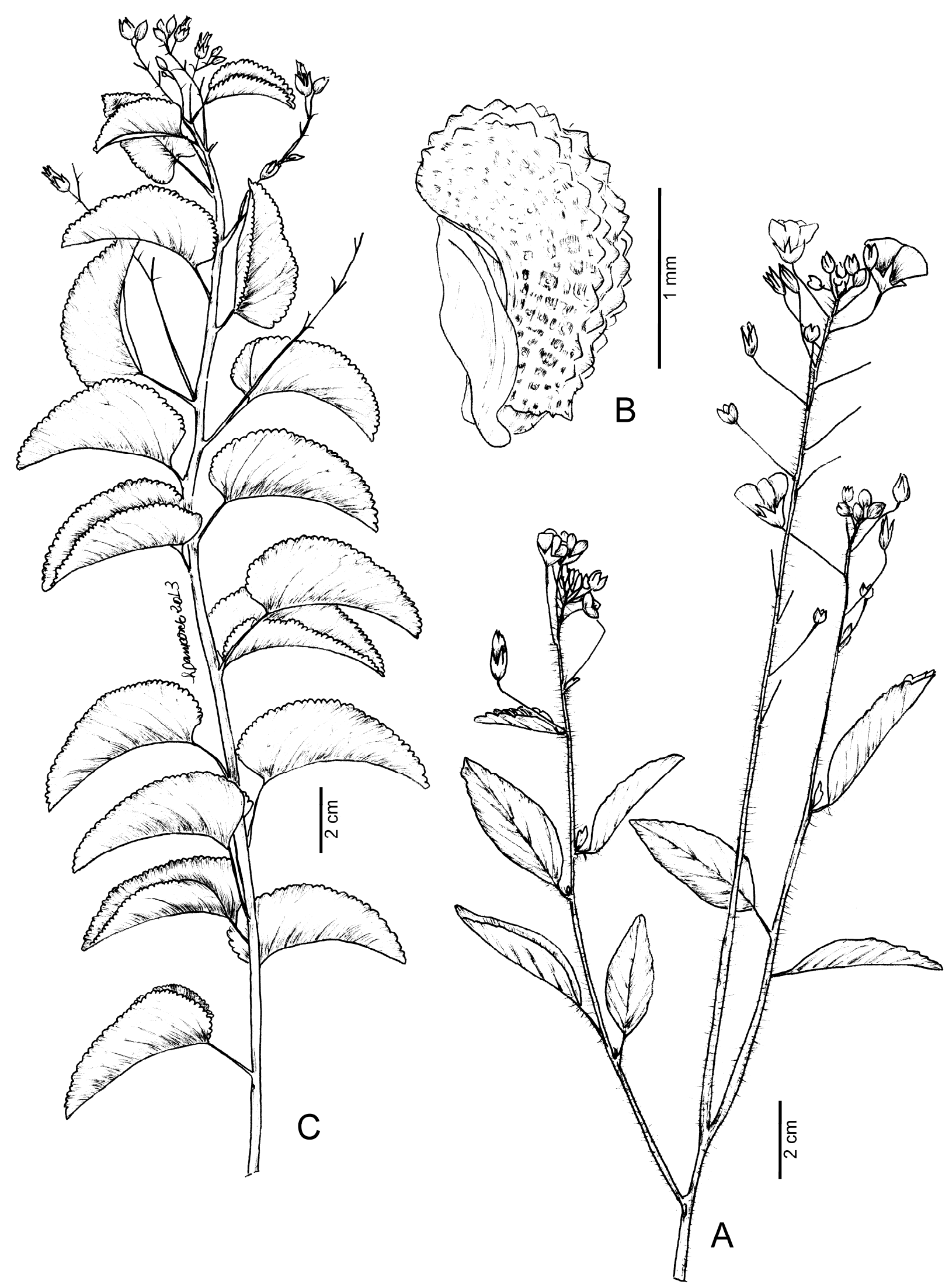

Figura 4. A, B. Piriqueta racemosa: A- ramo reprodutivo; B- semente (Harley 56193). C. P. sarae: ramo reprodutivo (Arbo 7604).

Material selecionado - Livramento do Brumado, $5 \mathrm{~km} \mathrm{~S} \mathrm{de}$ Rio de Contas, na estrada de terra para Livramento do Brumado,

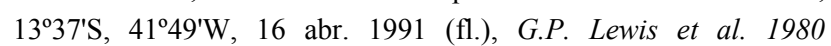

(CEPEC, CTES, K-foto); Oliveira dos Brejinhos, estrada Canabrava para Chapadão de Cima, $12^{\circ} 19^{\prime} 01^{\prime \prime} \mathrm{S}, 42^{\circ} 53^{\prime} 45^{\prime \prime} \mathrm{W}, 16$ mar. 1998 (fl., fr.), G. Hatschbach et al. 67854 (CEPEC, CTES, 
MBM); Palmeiras, Barraca do Pelé, $12^{\circ} 34^{\prime} 00^{\prime \prime S}, 41^{\circ} 22^{\prime} 59^{\prime \prime} \mathrm{W}, 22$ ago. 2009 (fl., fr.), J.C. Brito \& J. Marques 148 (HUEFS); Rio de Contas, arredores do povoado de Mato Grosso, no cafezal,

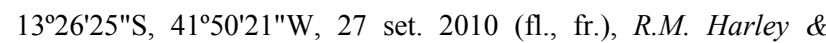
J.F.B. Pastore 56174 (HUEFS).

Pode ser reconhecida pelas folhas lustrosas e viscosas, recurvadas e inflorescências alongadas com flores de corola laranja a laranja-avermelhada, além das sementes, com uma depressão puntiforme em cada aréola. Assemelha-se a $P$. flammea, que se diferencia pelas folhas marcadamente discolores com face abaxial tomentosa. Arbo (1995) considerou duas variedades para esta espécie: $P$. sarae var. sarae e $P$. sarae var. glabrescens (Urb.) Arbo; apenas a primeira ocorre na Bahia. Piriqueta sarae var. glabrescens é conhecida apenas pelo exemplar-tipo, proveniente do estado de Minas Gerais, coletado por Martius há quase 200 anos (Spix \& Martius 1981), de modo geral, pode ser reconhecida pelo menor número de flores por inflorescência ( 2 ou 3 flores vs. 4-6 flores na variedade típica) e pecíolos mais curtos (3-5 mm compr. vs. 3-20 $\mathrm{mm}$ compr. na variedade típica).

1.20. Piriqueta scabrida Urb., Repert. Spec. Nov. Regni Veg. 4: 130. 1907.

Figuras 24; Arbo (1995: 39A-E).

Subarbustos $30-80 \mathrm{~cm}$ alt.; caules hirsutos, tricomas tectores estrelados e estrelado-porrectos, marrom-dourados, tricomas glandulares ausentes. Estípulas reduzidas a coléteres, 0,3-0,5 mm compr. Folhas com pecíolo até ca. $2 \mathrm{~mm}$ compr.; lâmina 1-4× 0,5-2,5 cm, coriácea, ligeiramente patente, aplanada, estreito-ovada a elíptica, base arredondada, ápice agudo a obtuso, margens serreado-crenadas, raramente inteiras nas folhas apicais, planas ou ligeiramente revolutas; face adaxial denso-pilosa, não bulada, nervuras impressas, face abaxial tomentosa, nervuras proeminentes. Inflorescências unifloras, axilares; pedúnculo 5-20 $\mathrm{mm}$ compr.; bractéolas reduzidas a coléteres, 0,3-0,5 $\mathrm{mm}$ compr. Flores heterostilas; pedicelo 3-10 $\mathrm{mm}$ compr. Cálice 8-15 $\mathrm{mm}$ compr., externamente tomentoso, marrom-dourado. Corola 1,7-1,9 cm compr., alaranjada. Filetes ca. $8 \mathrm{~mm}$ compr. em flores brevistilas, 4-5 mm compr. em flores longistilas, glabros; anteras 1,5-1,7 mm compr. Ovário 2-3 mm compr.; estiletes ca. $2 \mathrm{~mm}$ compr. em flores brevistilas, 4,5-6 $\mathrm{mm}$ compr. em flores longistilas, glabros; estigmas penicelados. Cápsulas 6-7 $\mathrm{mm}$ diâm.; epicarpo granuloso-tuberculado, hirsuto. Sementes ca. 2,3 × $0,7 \mathrm{~mm}$, oblongo-cilíndricas, ligeiramente curvas; epiderme reticulada.

Conhecida apenas pelo material-tipo. B5: região de Remanso. Encontrada com flores e frutos no mês de janeiro.

Material examinado - "Taboleiros Weg nach Remanso", aprox. 09 $37^{\prime} \mathrm{S}, 42^{\circ} 04^{\prime} \mathrm{W}, 200-500 \mathrm{~m}$, jan. 1907 (fl., fr.), E. Ule 7505 (holótipo F [foto 13559], lectótipo HBG-foto).

Reconhecida pelas folhas sésseis ou curtopecioladas, estreito-ovadas a elípticas, aplanadas, lustrosas em ambas as faces. Assemelha-se com $P$. duarteana (Urban 1907), a qual se diferencia pelas folhas geralmente longo-pecioladas e epicarpo com tricomas glandulares setiformes de base castanhoescura. $\mathrm{O}$ formato e a disposição das folhas remete a $T$. oblongifolia, que se diferencia pelas flores epífilas e desprovidas de corona.

\subsection{Piriqueta sidifolia (Cambess.) Urb., Jahrb.} Königl. Bot. Gart. Berlin 2: 61. 1883.

Figuras 5A e 24; Arbo (1995: fig. 28A-G); Rocha \& Moreira (2014: fotos 21-23).

Arbustos, subarbustos, raro ervas 0,2-2 m alt.; caules tomentosos, tricomas tectores simples, estrelados, estrelado-porrectos e glandulares setiformes, dourados. Estípulas rudimentares. Folhas com pecíolo (0,3-)0,8-3,7 cm compr.; lâmina 1,5-9($10,5) \times 1-4,3 \mathrm{~cm}$, cartácea, discolor, aplanada ou recurvada, ovada, estreito-ovada, elíptica, raro obovada, base arredondada a cordada, às vezes cuneada, ápice agudo ou obtuso, margens simples ou duplamente crenadas a serreado-crenadas, revolutas; face adaxial esparso a denso-pilosa, bulada, nervuras fortemente impressas, face abaxial tomentosa, nervuras proeminentes. Inflorescências em cincinos 2-16floros; pedúnculo 0,7-5 cm compr.; bractéolas 0,5-4 $\mathrm{mm}$ compr., linear-triangulares. Flores heterostilas; pedicelo (3-)5-13 mm compr. Cálice 5-10 $\mathrm{mm}$ compr., externamente tomentoso, dourado-ferrugíneo. Corola 9-15 mm compr., creme ou amarelo-clara, base das pétalas amarelo-escura, com estrias amareloescuras. Filetes 3-6 $\mathrm{mm}$ compr. em flores brevistilas, 2,5-3 mm compr. em flores longistilas; anteras 1-3,3 mm compr. Ovário 1,5-2 mm compr.; estiletes 1,5-2 $\mathrm{mm}$ compr. em flores brevistilas, 3-5 $\mathrm{mm}$ compr. em flores longistilas, glabros; estigmas penicelados. Cápsulas 7-11 mm diâm.; epicarpo granuloso a tuberculado, esparso-hirsuto. Sementes 2,5-3 × 1-1,4 $\mathrm{mm}$, estreito-obovoides, ligeiramente curvas; epiderme papilosa.

Amplamente distribuída no Brasil, ocorre nas Regiões Centro-Oeste (Distrito Federal, Goiás e Mato Grosso do Sul), Nordeste (Bahia, Ceará, Maranhão, Pernambuco e Piauí), Norte (Tocantins), Sudeste (Minas Gerais) e Sul (Rio Grande do Sul) (Arbo 2015). B/C8, C5, C9, E2, E4, E5/6, E6, F3, F5, F6, F7, G3, G5, H6: caatingas, campos rupestres, áreas de transição cerrado/caatinga, cerrados (carrasco) e campos gerais. Associa-se aos mais diversos ambientes, comum principalmente em áreas abertas, afloramentos rochosos, margens de trilhas a rodovias, encostas rochosas, às vezes em terrenos baldios, sujeitos à ação do fogo. Cresce em substratos arenosos, argilosos ou rochosos, ou entre fissuras de rochas, em altitudes de 350-1250 m. Apresenta flores e frutos durante o ano inteiro.

Material selecionado - Abaíra, base da encosta da Serra da Tromba, 13ำ' $1{ }^{\circ}, 4^{\circ} 48^{\prime} \mathrm{W}, 1000-1200$ m, 2 fev. 1992 (fl., fr.), J.R. Pirani et al. 51428 (K-foto, SPF); Barra da Estiva, a $6 \mathrm{~km}$ do rio 
Sincorá, estrada para Sincorá Velho, $13^{\circ} 31^{\prime} \mathrm{S}, 41^{\circ} 13^{\prime} \mathrm{W}, 1000 \mathrm{~m}, 24$ nov. 1992 (fl., fr.), R. Mello-Silva et al. 800 (CTES, HUEFS, Kfoto, SPF, UB); Barra do Mendes, estrada para Canarina, 12 $09^{\prime} 20^{\prime \prime S}, 42^{\circ} 01^{\prime} 03^{\prime \prime W}, 1038$ m, 16 dez. 2009 (fl., fr.), E. Melo et al. 7638 (ALCB, HUEFS); Barreiras, subida para a Serra da Bandeira, 1209'10"S, 4459'24"W, 3 maio 2013 (fl., fr.), L. Rocha 454 (HUEFS, RB); Bom Jesus da Lapa, estrada para Macaúbas, entre os distritos de São José e Laranjeiras, 13¹8'35"S, 42 $54^{\prime} 43^{\prime \prime W}, 821$ m, 12 jan. 2008 (fl., fr.), U.C.S. Silva et al. 19 (HUEFS); Boquira, Serra Geral, Serra do Brejo Grande, 12²9'22"S, 4243'51"W, 11 mar. 1998 (fl., fr.), G. Hatschbach et al. 67643 (CEPEC, CTES, MBM); Caetité, 9 km antes de Caetité, estrada saindo de Brejinho das Ametistas, após o posto de mineração, 14 ${ }^{\circ} 15^{\prime} 37^{\prime \prime S}, 42^{\circ} 31^{\prime} 27^{\prime \prime} \mathrm{W}, 27$ abr. 2013 (fl., fr.), L. Rocha \& P. Gomes 427 (CTES, HUEFS); Canudos, Estação Biológica de Canudos, $10^{\circ} 01^{\prime} \mathrm{S}, 39^{\circ} 09^{\prime} \mathrm{W}, 22$ nov. 2003 (fl., fr.), F.H.M. Silva et al. 467 (HUEFS); Cocos, rodovia Cocos-Coribe, $14 \mathrm{~km}$ da sede do município, $14^{\circ} 04^{\prime} 08^{\prime \prime S}, 44^{\circ} 29^{\prime} 47^{\prime \prime} \mathrm{W}, 670$ m, 18 abr. 2001 (fl., fr.), J.G. Jardim et al. 3657 (CEPEC, CTES); Coribe, ca. $10 \mathrm{~km} \mathrm{~L} \mathrm{de}$

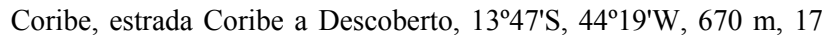
abr. 2002 (fl., fr.), F. França et al. 3840 (CTES, HUEFS); Correntina, Espigão Mestre, BR-349, $64 \mathrm{~km} \mathrm{~L}$ do trevo com a

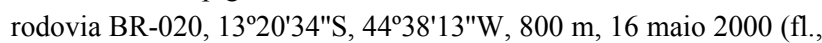
fr.), G. Hatschbach et al. 71237 (CEPEC, CTES, MBM); Cristópolis, BR-242, 12 $14^{\prime} 02^{\prime \prime} \mathrm{S}, 4^{\circ} 25^{\prime} 15^{\prime \prime} \mathrm{W}, 10$ out. 1981 (fl., fr.), G. Hatschbach 44143 (CTES, MBM); Ibicoara, 10-15 km a W de Capão de Volta, estrada para Jussiape, $13^{\circ} 30^{\prime} \mathrm{S}, 41^{\circ} 30^{\prime} \mathrm{W}, 20$ jan. 1997 (fl., fr.), M.M. Arbo et al. 7582 (CEPEC, CTES, K); Igaporã, BR-430, trevo para Tanque Novo, 134' $22^{\prime \prime} \mathrm{S}, 42^{\circ} 42^{\prime} 50^{\prime \prime} \mathrm{W}, 1000 \mathrm{~m}$, 5 abr. 1992 (fl., fr.), G. Hatschbach et al. 56627 (CEPEC, CTES, Kfoto, MBM, NY-foto, UPCB); Jaborandi, 9,5 km da sede do município, 13³4'01"S, 4430'33"W, 680 m, 19 abr. 2001 (fl., fr.), J.G. Jardim et al. 3675 (CEPEC, CTES, NY-foto); Lencóis, a 2 km da entrada para a cidade, 12 $33^{\prime} 46^{\prime \prime S}, 41^{\circ} 23^{\prime} 24^{\prime \prime} \mathrm{W}, 2$ maio 2013 (fl., fr.), L. Rocha et al. 432 (CTES, HUEFS, RB); Licínio de Almeida, área do Saco da Onça, 14²41'23"S, 42³2'35"W, 867 m, 6 abr. 2013 (fl., fr.), L. Rocha et al. 401 (ALCB, CTES, HUEFS); Luiz Eduardo Magalhães, Mimoso do Oeste, Moriçoca, $12^{\circ} 06^{\prime} 22^{\prime \prime} \mathrm{S}$, 4553'46"W, s.d. (fl., fr.), A.B. Xavier et al. 201 (ALCB); Macaúbas, entre o alto da Serra Poções e a lagoa do Maurício, 1301'08"S, 42 $04^{\circ} 56^{\circ} \mathrm{W}, 27$ nov. 2004 (fl., fr.), G. Hatschbach et al. 78631 (CTES, MBM); Maracás, ca. $6 \mathrm{~km} \mathrm{SW}$ da cidade, 13²6'S, $40^{\circ} 27^{\prime} \mathrm{W}, 13$ out. 1983 (fl., fr.), A.M. Carvalho et al. 1976 (CEPEC, HRB, RB); Morro do Chapéu, estrada em direção a Feira da Mata, próximo ao rio Carinhanha, $14^{\circ} 15^{\prime} 11^{\prime \prime} \mathrm{S}, 4^{\circ} 22^{\prime} 14^{\prime \prime} \mathrm{W}, 484 \mathrm{~m}, 9$ jan. 2008 (fl., fr.), A.L. Côrtes et al. 61 (HUEFS); Mucugê, estrada Andaraí-Mucugê, $5 \mathrm{~km}$ da cidade, $13^{\circ} 00^{\prime} \mathrm{S}, 41^{\circ} 37^{\prime} \mathrm{W}, 17$ jan. 2012 (fl., fl.), L. Rocha et al. 353 (CTES, HUEFS); Oliveira dos Brejinhos, estrada para Chapada de Cima, $12^{\circ} 22^{\prime} \mathrm{S}, 42^{\circ} 54^{\prime} \mathrm{W}, 870$ m, 18 dez. 2007 (fl., fr.), A.A. Conceição et al. 2780 (HUEFS); Palmeiras, proximidades do povoado São João, $12^{\circ} 26^{\prime} 17^{\prime \prime S}$, 4130'52"W, 2 maio 2013 (fl., fr.), L. Rocha et al. 435 (HUEFS); Paramirim, $12 \mathrm{~km}$ da cidade, na estrada para Livramento do Brumado, 13 $333^{\prime} \mathrm{S}, 42^{\circ} 13^{\prime} \mathrm{W}, 600 \mathrm{~m}, 30$ nov. 1988 (fl., fr.), R.M. Harley \& N. Taylor 27030 (CEPEC, CTES, K-foto, SPF); Piatã, estrada para Catolés, $13^{\circ} 13^{\prime} \mathrm{S}, 41^{\circ} 44^{\prime} \mathrm{W}, 1000 \mathrm{~m}, 3$ fev. 2005 (fl., fr.), J. Paula-Souza et al. 5385 (CTES, ESA); Rio de Contas, Arapiranga, 132' $50^{\prime \prime} \mathrm{S}, 41^{\circ} 46^{\prime} 21^{\prime \prime} \mathrm{W}, 683$ m, 11 fev. 2010 (fl., fr.), N. Roque et al. 2637 (ALCB); São Desidério, estrada sentido Roda Velha, $9 \mathrm{~km}$ da entrada para o Sítio Grande, $12^{\circ} 25^{\prime} 36^{\prime \prime} \mathrm{S}$,
4504'23"W, 4 maio 2013 (fl., fr.), L. Rocha et al. 469 (HUEFS); São Félix do Coribe, Ponta D'Água, em direção a Descoberto,

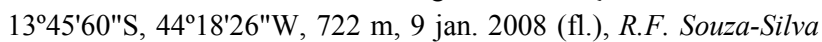
et al. 282 (HUEFS); Seabra, $10 \mathrm{~km}$ da cidade, sentido Ibotirama, $12^{\circ} 25^{\prime} \mathrm{S}, 41^{\circ} 46^{\prime} \mathrm{W}, 2$ maio 2013 (fl., fr.), L. Rocha et al. 436 (HUEFS); Tucano, Sítio do Mandacaru, 1052'29"S, 3846'19"W, 391-411 m, 15 abr. 2006 (fl., fr.), D. Cardoso et al. 1190 (HUEFS); Vanderlei, $5 \mathrm{~km} \mathrm{~S}, 12^{\circ} 07^{\prime} \mathrm{S}, 4^{\circ} 54^{\prime} \mathrm{W}, 19$ jun. 1986 (fl., fr.), $G$. Hatschbach \& J.M. Silva 50501 (C-foto, CEPEC, CTES, K-foto, MBM, US-foto); Vitória da Conquista, BR-116, distrito industrial, 3 $\mathrm{km}$ antes da cidade, 1451'57"S, 4050'20"W, 25 abr. 2013 (fl.), $L$. Rocha \& P. Gomes 413 (CTES, HUEFS, RB); Xique-Xique, rodovia Xique-Xique para Barra, Km 10-15, 1049'19"S, 4243'51"W, 13 mar. 1998 (fl., fr.), G. Hatschbach et al. 67732 (CTES, MBM).

Pode ser reconhecida pelas folhas geralmente ovadas, de base arredondada a cordada, margens simples ou duplamente crenadas a serreado-crenadas. As inflorescências são geralmente longas, com flores grandes, apresentando corola creme ou amarelo-clara, com base das pétalas amarelo-escura e estrias amareloescuras. Piriqueta sidifolia assemelha-se a $P$. densiflora, a qual se diferencia, principalmente, pelas folhas estreito-oblongas, estreito-elípticas a lineares, geralmente ferrugíneas ou verde acinzentadas. As flores foram encontradas abertas até 16:00 hs, visitadas por besouros e borboletas.

Arbo (1995) considerou duas variedades para esta espécie: $P$. sidifolia var. sidifolia e $P$. sidifolia var. multiflora Urb., ambas ocorrentes na Bahia. A variedade típica apresenta hábito herbáceo ou subarbustivo, folhas com pecíolos curtos, 0,5-7 $\mathrm{mm}$ compr., inflorescências 2-3(-6)-floras, e ocorre principalmente na região Centro-Oeste do Brasil. Já $P$. sidifolia var. multiflora possui hábito subarbustivo a arbustivo, folhas com pecíolos geralmente longos, 0,92(-3) cm compr., e inflorescências 4-20-floras, sendo mais comum na Região Nordeste.

\subsection{Piriqueta sulfurea Urb. \& Rolfe, Jahrb. Königl.}

Bot. Gart. Berlin 2: 62. 1883.

Figuras 5B, C e 25; Arbo (1995: fig. 26E-J).

Subarbustos 30-90 cm alt.; caules tomentosohirsutos, tricomas tectores simples, estrelados e estrelado-porrectos, dourados e glandulares setiformes. Estípulas rudimentares. Folhas com pecíolo $5-10 \mathrm{~mm}$ compr.; lâmina 3,5-8 × 0,9-2,6 cm, cartácea, concolor, aplanada, elíptica a obovada, base atenuada a cuneadoatenuada, ápice agudo ou obtuso, margens discretamente serreada a serreado-crenadas, planas a ligeiramente revolutas; face adaxial denso-pilosa, não bulada, nervuras discretamente impressas, face abaxial tomentosa, nervuras proeminentes. Inflorescências em cincinos 2 ou 3-floros; pedúnculo 1-3,5 cm compr.; bractéolas até ca. $0,7 \mathrm{~mm}$ compr., linear-triangulares. Flores heterostilas; pedicelo 5-7 mm compr. Cálice 6$8 \mathrm{~mm}$ compr., externamente tomentoso-hirsuto, amarelo-dourado. Corola 1,2-1,3 cm compr., creme ou amarelo-alaranjada. Filetes ca. $4 \mathrm{~mm}$ compr. em flores brevistilas, ca. $3 \mathrm{~mm}$ compr. em flores longistilas, 
glabros; anteras ca. $2 \mathrm{~mm}$ compr. Ovário ca. $2 \mathrm{~mm}$ compr.; estiletes ca. $2 \mathrm{~mm}$ compr. em flores brevistilas, ca. 4,5 mm compr. em flores longistilas, glabros; estigmas pseudocapitados a penicelados. Cápsulas 6-7 mm diâm.; epicarpo granuloso, hirsuto. Sementes 2$2,7 \times 1-1,3 \mathrm{~mm}$, obovoides, ligeiramente curvas; epiderme papilosa.

Ocorre no Ceará e Piauí (Arbo 2015). Através deste estudo, amplia-se sua área de distribuição para a o estado da Bahia. A8, B9: caatinga arbustivo-arbórea. Foi encontrada crescendo em substratos arenosos, com flores e frutos em julho.

Material examinado - Curaçá, Pedra Branca, Complexo Itaparica, 08³6'03"S, 39²9'43"W, 2 jul. 2006 (fl., fr.), M. Oliveira et al. 2471 (UFP); Glória, (RPPN), complexo Itaparica, 09¹1'34"S, $38^{\circ} 26^{\prime} 00^{\prime \prime} \mathrm{W}, 325 \mathrm{~m}, 1$ jul. 2006 (fl., fr.), M. Oliveira et al. 2440 (UFP).

Material adicional examinado - BRASIL. Piauí: Oeiras, Alto do Morro do Cruzeiro, 07 $01^{\prime} 03^{\prime \prime} \mathrm{S}, 4^{\circ} 08^{\prime} 35^{\prime \prime} \mathrm{W}, 221 \mathrm{~m}, 23$ jan. 2012 (fl.), R.M. Harley et al. 56385 (HUEFS).

Reconhecida pelas folhas grandes, longopecioladas, elípticas a elíptico-obovadas, concolores, com indumento dourado-pálido em ambas as faces, quando secas. Além da corola creme ou amareloalaranjada e sementes com epiderme papilosa. Devido à coloração dos espécimes quando secos e a forma das folhas, é ligeiramente similar a Piriqueta duarteana, a qual se diferencia pelos pecíolos geralmente mais curtos e inflorescências unifloras, com flores de corola salmão a rosa.

1.23. Piriqueta viscosa Griseb., Cat. Pl. Cub.: 114. 1866.

Figuras 25; Arbo (1995: fig. 48A-C).

Ervas a subarbustos $20-50 \mathrm{~cm}$ alt.; caules hirsutos, tricomas tectores simples, estrelado-porrectos, glandulares setiformes, dourados. Estípulas rudimentares. Folhas com pecíolo 1-4 mm compr.; lâmina $1,5-6 \times 0,5-2 \mathrm{~cm}$, papirácea, discolor ou concolor, recurvada, elíptica, estreito-ovada ou lanceolada, base atenuada, ápice agudo, margens simples ou duplamente serreadas a serreado-crenadas, planas; face adaxial esparso-pilosa, não bulada, nervuras impressas, face abaxial esparso-pilosa, nervuras proeminentes. Inflorescências unifloras, axilares; pedúnculo 1,6-3,5 cm compr.; bractéolas rudimentares. Flores homostilas; pedicelo 2-4 $\mathrm{mm}$ compr. Cálice 4-5 mm compr., externamente hirsuto, amarelo-dourado. Corola 6-7 mm compr., rosa a rosaescuro com base das pétalas roxa, ou amareloalaranjada com base das pétalas castanho-escura. Filetes 2,5-3 mm compr., glabros; anteras 0,5-0,7 mm compr. Ovário ca. 1,5 mm compr.; estiletes $1-1,5 \mathrm{~mm}$ compr., glabros; estigmas penicelados. Cápsulas 5-7 mm diâm.; epicarpo granuloso, hirsuto. Sementes 1,5$2 \times 0,7-1 \mathrm{~mm}$, obovoides, estreito-obovoides a clavadas, retas ou ligeiramente curvas; epiderme lisa.

Amplamente distribuída, na Mesoamérica, Antilhas até a Colômbia e Venezuela. No Brasil, ocorre no
Centro-Oeste (Mato Grosso do Sul e Mato Grosso), Nordeste (Bahia, Ceará, Maranhão, Paraíba, Piauí e Rio Grande do Norte), Norte (Pará, Roraima) e Sudeste (Espírito Santo, Minas Gerais e Rio de Janeiro) (Arbo 2015). B6, B/C5, C7, C8, D5, D6, D7, E2/3, E5, E6, E8, E9, F6, G5, G6, H8, I8: caatingas, áreas de transição caatinga/cerrado, campos rupestres, restingas, dunas e cerrados. Associa-se aos mais diversos ambientes, como áreas abertas, terrenos baldios, margens de rodovias a trilhas, encostas, sendo comum em zonas urbanas, em altitudes até $1130 \mathrm{~m}$. Apresenta flores e frutos durante o ano todo.

Material selecionado - Andaraí, $24 \mathrm{~km}$ ao sul de Andaraí, estrada para Mucugê, $12^{\circ} 55^{\prime} \mathrm{S}, 4^{\circ} 19^{\prime} \mathrm{W}, 800-900$ m, 20 jan. 1997 (fl., fr.), M.M. Arbo et al. 7549 (CEPEC, CTES, RB); Barreiras, subida para a Serra do Mimo, 1209'10"S, 4459'24"W, 3 maio 2013 (fl., fr.), L. Rocha et al. 453 (HUEFS); Caetité, $10 \mathrm{~km}$ antes de Caetité, estrada saindo de Brejinho das Ametistas, antes do posto de mineração, $14^{\circ} 08^{\prime} \mathrm{S}, 41^{\circ} 57^{\prime} \mathrm{W}, 27$ abr. 2013 (fl., fr.), L. Rocha \& P. Gomes 425 (HUEFS); Camaçari, região metropolitana de Salvador, Arembepe, Paradiso Laguna, 12 $41^{\prime} \mathrm{S}, 38^{\circ} 19^{\prime} \mathrm{W}, 2$ jun. 2007 (fl., fr.), M.L. Guedes et al. 13884 (ALCB); Casa Nova, Beira da estrada, $09^{\circ} 16^{\prime} 13^{\prime \prime S}, 41^{\circ} 12^{\prime} 53^{\prime \prime W}, 416$ m, 25 maio 2009 (fl., fr.), M. Oliveira et al. 4114 (CTES, HVASF); Castro Alves, 12\%45'57"S, 39²5'40"W, jul. 1952 (fl., fr.), G. Pinto s.n. (ALCB 6722); Feira de Santana, Campus da UEFS, 12¹1'50"S, 38 58'14"W, 8 jun. 2006 (fl., fr.), E. Melo \& L. Damascena 4447 (HUEFS); Filadélfia, a 14 km da BR-407, 1048'S, 40 $14^{\prime}$ W, 16 jan. 1997 (fl., fr.), M.M. Arbo et al. 7336 (ALCB, CEPEC, CTES, K-foto, MBM); Gentio do Ouro, $34 \mathrm{~km} \mathrm{NE}$ na estrada para São Inácio, $11^{\circ} 16^{\prime} \mathrm{S}, 42^{\circ} 41^{\prime} \mathrm{W}$, 800-1000 m, 23 fev. 1977 (fl., fr.), R.M. Harley et al. 18970 (CEPEC, CTES, E-foto, IPA, K-foto); Ilhéus, estrada Una-Ilhéus, $15^{\circ} 04^{\prime} 05^{\prime \prime S}, 38^{\circ} 59^{\prime} 54^{\prime \prime W}, 10$ m, 5 fev. 2002 (fl., fr.), M. Groppo Jr. et al. 1050 (CTES, SPF); Itiúba, 14-19 km W da cidade, estrada para Filadélfia, 1041'27"S, 3951'10"W, 12 jan. 1992 (fl., fr.), M.M. Arbo et al. 5464 (CTES, SPF); Jacobina, Serra do Tombador, 19

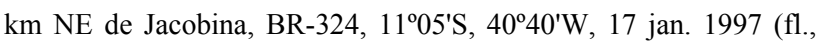
fr.), M.M. Arbo et al. 7395 (ALCB, CEPEC, CTES, HRB, HUEFS,

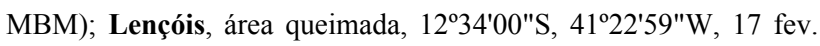
2009 (fl., fr.), J.C. Brito \& J. Marques 93 (HUEFS); Licínio de

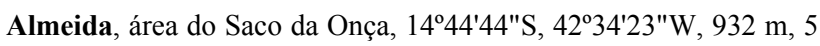
abr. 2013 (fl., fr.), L. Rocha et al. 398 (ALCB, HUEFS); Livramento de Nossa Senhora, ca. 1,6 km de Livramento na estrada para Lagoa Nova, 13ํㄱ' $\mathrm{S}, 41^{\circ} 46^{\prime} \mathrm{W}, 485$ m, 31 jan. 2005 (fl., fr.), J. Paula-Souza et al. 5205 (CTES, ESA); Morro do Chapéu, BA-052, $18 \mathrm{~km}$ de Morro do Chapéu, estrada para a cachoeira do Ferro Doido, $11^{\circ} 55^{\prime} \mathrm{S}, 41^{\circ} 15^{\prime} \mathrm{W}, 28$ jan. 2013 (fl., fr.), L. Rocha \& B.S. Gregório 384 (HUEFS, RB); Mucugê, $5 \mathrm{~km}$ da cidade, $13^{\circ} 00^{\prime} \mathrm{S}, 41^{\circ} 37^{\prime} \mathrm{W}, 17$ jan. 2012 (fl., fl.), L. Rocha et al. 355 (HUEFS); Oliveira dos Brejinhos, rodovia para Macaúbas, $\mathrm{Km} 8$, 12 ${ }^{\circ} 19^{\prime} \mathrm{S}, 42^{\circ} 54^{\prime} \mathrm{W}, 20$ abr. 1996 (fl., fr.), G. Hatschbach et al. $65099 b$ (CTES, MBM); Palmeiras, estrada para o Capão, próximo

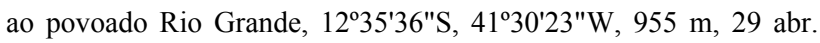
2012 (fl., fl.), L. Rocha \& I. Souza 372 (HUEFS); Pindaí, BR-122, $7 \mathrm{~km} \mathrm{~N}$ de Pindaí, 14²9'S, 4241'W, 15 jan. 1997 (fl., fr.), G. Hatschbach et al. 65797 (CTES, MBM); Porto Seguro, 16 27'00"S, 3903'54"W, 19 jun. 1962 (fr.), A.P. Duarte 6793 (RB); Rio de Contas, fazenda Fiuza, $13^{\circ} 27^{\prime} 33^{\prime \prime} \mathrm{S}, 4^{\circ} 52^{\prime} 24^{\prime \prime W}, 1130 \mathrm{~m}, 4 \mathrm{fev}$. 1997 (fl., fr.), L. Passos et al. PCD 5035 (ALCB, HUEFS); 


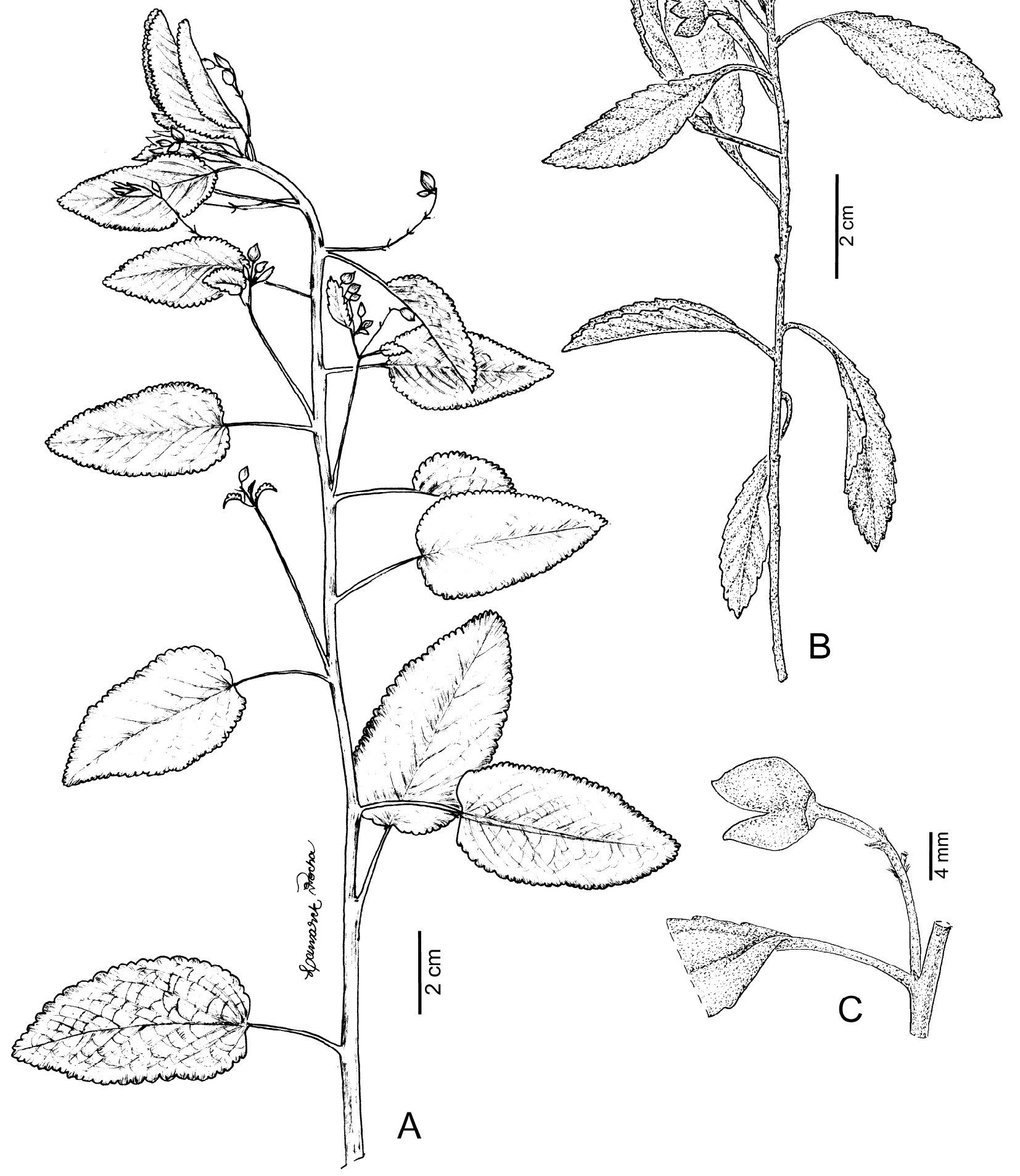

Figura 5. A. Piriqueta sidifolia: ramo reprodutivo (Krapovickas 37876). B, C. P. sulfurea: B- ramo reprodutivo; C- inflorescência já com fruto (Mendes 324) (B e C por Liliana Gomes).

Salvador, Dunas de Itapuã, $12^{\circ} 56^{\prime} \mathrm{S}, 38^{\circ} 21^{\prime} \mathrm{W}, 22$ set. 1983 (fl., fr.), L.R. Noblick 1626 (ALCB, HUEFS); Una, ca. 30 km de Ilhéus na BA-001, próximo ao povoado do Açuípe, 15¹7'34"S, 3904'30"W, 6 jun. 1999 (fl., fr.), J.G. Jardim 2159 (CEPEC, CTES, NY-foto); Xique-Xique, 15 $\mathrm{km} \mathrm{S}$ da cidade, estrada para Santo Inácio, $10^{\circ} 58^{\prime} \mathrm{S}, 42^{\circ} 41^{\prime} \mathrm{W}, 19$ jan. 1997 (fl., fr.), M.M. Arbo et al. 7524 (CEPEC, CTES). 
Pode ser reconhecida pelos caules viscosos, com folhas também viscosas, elípticas, estreito-ovadas ou lanceoladas, com margens simples ou duplamente serreadas a serreado-crenadas e recurvadas. Suas flores são homostilas e a corola varia de coloração: pode ser rosa, rosa-escuro ou amarelo-alaranjada. Assemelha-se vegetativamente a $P$. morongii Rolfe, que ocorre apenas no Centro-Oeste e se diferencia pelas flores geralmente maiores, heterostilas e sementes com epiderme papilosa.

Arbo (1995) considerou duas subespécies: $P$. viscosa subsp. viscosa e P. viscosa subsp. tovarensis Urb. A primeira é amplamente distribuída no Brasil e América do Sul, podendo ser reconhecida pela corola rosada e sementes estreito-obovoides a clavadas. A segunda pode ser reconhecida pela corola amarela ou alaranjada e sementes obovoides, mais curtas que na subespécie típica. Era conhecida apenas para a Costa Rica, Panamá, Colômbia, Venezuela, através deste estudo, foi encontrada pela primeira vez no Brasil.

\section{Turnera L.}

Arbustos, subarbustos ou ervas. Estípulas reduzidas a coléteres ou desenvolvidas, às vezes ausentes. Folhas papiráceas a coriáceas; nectários extraflorais presentes ou não, basilaminares ou peciolares, geralmente discoides. Inflorescências axilares; cimosas, unifloras, solitárias ou agrupadas no ápice dos ramos, às vezes congestas em capítulos ou racemos abreviados ou capituliformes, globosos; pedúnculo ausente ou desenvolvido, parcial ou totalmente adnato ao pecíolo (flor epífila); brácteas presentes ou ausentes; bractéolas 2, desenvolvidas, opostas, localizadas na base do cálice, raro na articulação do pedúnculo com o pedicelo. Flores homostilas ou heterostilas, às vezes sésseis. Cálice campanulado; lacínios estreito-triangulares, ápice agudo a mucronado. Corola em diferentes tons de amarelo, branca, ou raro vermelha. Corona ausente, raro com apêndice ou lígula na unha das pétalas. Filetes com base adnata ao tubo floral, ou com margens adnatas à unha das pétalas, formando sacos nectaríferos entre cada filete e a sépala correspondente; anteras ovoides a estreito-ovoides, dorsifixas ou basifixas. Ovário ovoide; estiletes glabros a pilosos. Cápsulas globosas a ovoides; epicarpo liso, tuberculado-crestado ou verrucoso. Sementes retas ou curvas, reticuladas ou estriadas; aréolas do retículo côncavas, com 1 depressão puntiforme; calaza arredondada, obtusa, proeminente ou cônica, superfície plana, côncava a umbilicada; arilo lobulado, lacerado, por vezes inteiro, igual, maior ou menor que a semente.

Turnera é o maior gênero da família, inclui 143 espécies, distribuídas dos Estados Unidos até a Argentina, além da África, onde ocorrem duas espécies. O Brasil apresenta 120 espécies, 86 delas endêmicas, com centro de diversidade na Cadeia do Espinhaço, na Bahia e em Minas Gerais (Arbo \& Mazza 2011; Arbo 2015). No estado da Bahia, são registradas 40 espécies, associadas aos mais diversos tipos de ambiente, principalmente cerrados, campos rupestres e caatingas.

\section{Chave para espécies}

1. Corola vermelha, base das pétalas amarela

1'. Corola de outra cor, nunca vermelha.

2. Inflorescências em capítulos ou em racemos abreviados, capituliformes.

3. Inflorescências em capítulos terminais; pedúnculo ausentes.

4. Corola branca, base das pétalas amarela

4'. Corola amarela.

5. Brácteas estreito-ovadas; bractéolas estreito-ovadas ou obovadas

2.1. T. albicans

5'. Brácteas largo-ovadas ou subcirculares; bractéolas obovadas ou oblongas

6. Caules com tricomas tectores simples. Brácteas largo-ovadas ............... 2.12. T. chrysocepala

6'. Caules com tricomas tectores simples e estrelados. Brácteas subcirculares

2.5. T. blanchetiana

3'. Inflorescências em racemos terminais abreviados, capituliformes; pedúnculo presente.

7. Folhas coriáceas, glabras

7'. Folhas papiráceas, pilosas.

8. Estípulas 2-9 mm compr., 3-4-sectadas. Brácteas linear-lanceoladas; pedúnculo floral livre ou adnato ao pecíolo. Unha das pétalas com apêndice $0,4-0,7 \mathrm{~mm}$ compr., cilíndrico, piloso

2.26. T. maracasana

8'. Estípulas 1,5-5 mm compr. Brácteas ovadas a obovadas; pedúnculo floral livre do pecíolo. Unha das pétalas desprovida de apêndice

2.2. T. annularis

2'. Inflorescências unifloras, solitárias, às vezes agrupadas no ápice dos ramos.

9. Filetes adnatos ao tubo floral apenas na base, às vezes livres.

10. Pedúnculo floral livre do pecíolo, às vezes adnato na porção proximal.

11. Fruto com epicarpo tuberculado-crestado, glabro 2.20. T. hindsiana

11'. Fruto com epicarpo granuloso ou verrucoso, piloso.

12. Caules com tricomas glandulares capitado-estipitados. 
13. Folhas pequenas, até ca. $4,5 \mathrm{~cm}$ compr., geralmente concolores; face abaxial esparso-pilosa (ruderal e amplamente distribuída na Bahia)

2.10. T. chamaedrifolia

13'. Folhas geralmente maiores, até ca. $10 \mathrm{~cm}$ compr., discolores; face abaxial vilosa (Chapada Diamantina)

2.6. T. caatingana

12'. Caules com tricomas glandulares capitado-sésseis.

14. Flores amarelas. Bractéolas linear-triangulares

14 '. Flores brancas a creme. Bractéolas elípticas, obovadas ou espatuladas.

15. Folhas discolores, obovadas, elípticas, raro ovadas, margens serreado-crenadas quase até a base

2.7. T. calyptrocarpa

15'. Folhas geralmente concolores, estreito-obovadas, margens com 1-4 pares de dentes

2.18. T. hebepetala

10'. Pedúnculo floral adnato ao pecíolo, às vezes, com porção apical livre.

16. Nectários extraflorais ausentes.

17. Folhas obovadas a elípticas. Bractéolas ovadas, assimétricas. Fruto com epicarpo granuloso

2.3. T. asymmetrica

17'. Folhas e bractéolas lineares. Fruto com epicarpo liso

2.16. T. genistoides

16'. Nectários extraflorais presentes.

18. Nectários extraflorais presentes apenas nas folhas floríferas.

19. Folhas elípticas a elíptico-obovadas, margens duplamente serreado-crenadas; as duas faces lanoso-tomentosas ........................................... 2.36. T. stachydifolia

19'. Folhas lineares, lanceoladas ou oblanceoladas, margens serrilhadas, geralmente com 3 ou 4 pares de dentes em cada lado da lâmina; face adaxial estrigosa, face abaxial denso-estrigosa

18'. Nectários extraflorais presentes em todas as folhas, raramente ausentes.

20. Folhas com margens denteadas a profundamente laciniadas ... 2.25. T. luetzelburgii

20'. Folhas com margens serreadas, crenadas às vezes inteiras.

21. Folhas com face abaxial tomentoso-velutina a lanoso-velutina.

22. Estípulas rudimentares. Tricomas tectores simples

2.40. T. uleana

22'. Estípulas 2-4 mm compr. Tricomas tectores simples, bífidos a estrelados

$21^{\prime}$. Folhas com face abaxial glabra ou com indumento diferente.

23. Caules e folhas glabros

23'. Caules e folhas pilosos.

24. Nervuras proeminentes nas duas faces

23. T. lamiifolia

24'. Nervuras impressas na face adaxial e proeminentes na face abaxial.

25. Ovário e fruto denso-hirsutos apenas no ápice. Sementes lunadas

2.39. T. trigona

5'. Ovário e fruto pilosos. Sementes obovoides.

26. Folhas com margens geralmente inteiras, raro serrilhadas; estiletes glabros

2.32. T. paradoxa

26'. Folhas com margens recortadas; estiletes com ápice esparso-piloso.

27. Folhas com margens duplamente serreado-crenadas, às vezes serreadas. Cálice 4-9 $\mathrm{mm}$ compr. Corola mais curta, igual ou até $3 \mathrm{~mm}$ maior que o cálice (ruderal e amplamente distribuída na Bahia)

2.28. T. melochioides

27'. Folhas com margens serrilhado-crenuladas. Cálice 9$12 \mathrm{~mm}$ compr. Corola 5-6 mm mais comprida que o cálice (apenas no sudoeste da Bahia)

2.30. T. opifera

9'. Filetes com margens adnatas à unha das pétalas, formando sacos nectaríferos.

28. Indumento composto por tricomas tectores simples e estrelados.

29. Corola creme, base das pétalas amarelo-escura às vezes com estrias marrons

2.19. T. hermannioides

29'. Corola amarela.

30. Bractéolas estreito-ovadas a linear-triangulares

2.9. T. cearensis

30'. Bractéolas largo-ovadas, foliáceas 2.21. T. involucrata 
28'. Indumento composto por tricomas tectores simples, nunca estrelados.

31. Sementes com calaza obtusa; superfície plana.

32. Flores heterostilas.

33. Corola branca, base das pétalas amarela, às vezes com estrias azul escuras.

33'. Corola amarela a creme.

34. Base das pétalas castanho-escura (ruderal)

2.13. T. coerulea

34'. Base das pétalas amarelo-intensa (restinga e dunas).

32. Flores homostilas.

35. Corola branca, base das pétalas amarela, às vezes com estrias azul escuras.

35'. Corola amarela a creme.

36. Base das pétalas amarelo-escura

.. 2.8. T. candida

36'. Base das pétalas castanho-escura

2.31. T. orientalis

2.14. T. cuneiformis

31'. Sementes com calaza proeminente; superfície côncava, umbilicada.

37. Folhas lineares a linear-lanceoladas. Cálice externamente esparso-estrigoso

2.37. T. stenophylla

37'. Folhas ovadas, estreito-ovadas, elípticas a obovadas. Cálice com indumento mais denso, externamente estrigoso ou denso-estrigoso.

38. Folhas discolores; face abaxial tomentosa. Corola creme ........ 2.24. T. leptosperma

$38^{\prime}$. Folhas concolores a ligeiramente discolores; face abaxial esparso a denso-estrigosa.

Corola amarela.

39. Folhas cartáceas, geralmente pequenas, $0,7-3,5(-5,5) \mathrm{cm}$ compr.; nectários $0,3-0,6 \mathrm{~mm}$ diâm.

2.35. T. simulans

39'. Folhas papiráceas, geralmente maiores, $1-8,5 \mathrm{~cm}$ compr.; nectários $0,7-1,3$ mm diâm...

2.22. T. joelii

2.1. Turnera albicans Urb., Jahrb. Königl. Bot. Gart. Berlin 2: 135. 1883.

Figuras 6A, B e 26; Arbo (2000: fig. 4A-G).

Arbustos $40-80 \mathrm{~cm}$ alt.; caules esparso-estrigosos, tricomas tectores simples. Estípulas $0,3-1,5 \mathrm{~mm}$ compr. Folhas com pecíolo 0,3-1 cm compr.; nectários 1-3 pares, 0,7-2 mm diâm.; lâmina 5-13 × 2,5-5 cm, coriácea, ligeiramente discolor, elíptica a obovada, base atenuada a cuneada, ápice agudo, margens serrilhadas, planas ou ligeiramente revolutas; face adaxial esparso-estrigosa apenas na nervura principal, nervuras impressas, face abaxial esparso-estrigosa, nervuras proeminentes. Inflorescências em capítulos terminais; pedúnculo ausente; brácteas 5-6(-11) × 2-3 $\mathrm{mm}$, largo-ovadas, 1 ou 2 pares de nectários; bractéolas 1,5-2,8 mm compr., obovadas a espatuladas. Flores heterostilas; pedicelo ausente. Cálice 4-5 $\mathrm{mm}$ compr., externamente denso-piloso. Corola 5-6 $\mathrm{mm}$ compr., branca, base das pétalas amarela. Filetes ca. $4 \mathrm{~mm}$ compr. em flores brevistilas, ca. $3 \mathrm{~mm}$ compr. em flores longistilas, ápice esparso-piloso, base ca. $1 \mathrm{~mm}$ adnata ao tubo floral; anteras $0,6-0,8 \mathrm{~mm}$ compr., dorsifixas. Ovário 1-1,7 $\mathrm{mm}$ compr., tomentosohirsuto; estiletes 1-1,7 $\mathrm{mm}$ compr. em flores brevistilas, 3,5-4 $\mathrm{mm}$ compr. em flores longistilas, denso-pilosos; estigmas lobulados. Cápsulas 2,5-5 mm diâm.; epicarpo verrucoso, esparso-piloso. Sementes $2-3 \times 1-1,5 \mathrm{~mm}$, obovoides, ligeiramente curvas, reticuladas; epiderme papilosa; calaza proeminente, superfície côncava.

Rara, endêmica do litoral sul da Bahia (Arbo \& Giulietti 2009; Arbo 2015). G8, I8/9: restingas e capoeiras. Encontrada no interior da mata, áreas perturbadas ou margens de rodovias, crescendo em substratos arenosos. Apresenta flores e frutos nos meses de fevereiro, março, junho, outubro e novembro.

Material selecionado - Ilhéus, fazenda Barra do Manguinho, ramal com entrada no $\mathrm{Km} 10$ da rodovia Pontal/Olivença, $14^{\circ} 50^{\prime} \mathrm{S}$, $39^{\circ} 01^{\prime} \mathrm{W}, 20$ m, 11 fev. 1993 (fl.), L.A. Mattos-Silva et al. 2912 (CEPEC, NY-foto); Santa Cruz Cabrália, ca. 13,7 km da Ponta de Santo Antônio, rodovia para Belmonte, 16 $6^{\circ} 10^{\prime} 22^{\prime \prime} \mathrm{S}, 38^{\circ} 58^{\prime} 16^{\prime \prime} \mathrm{W}, 19$ jun. 2005 (fl., fr.), J.G. Jardim et al. 4632 (CTES, HUEFS).

Pode ser reconhecida pelas inflorescências em capítulos globosos, brácteas largo-ovadas e corola branca. As sementes apresentam uma depressão puntiforme em cada aréola. Turnera albicans se assemelha vegetativamente a $T$. maracasana, a qual se diferencia pelas estípulas 3-4-sectadas, com 2-9 mm compr. e apêncide piloso na unha das pétalas.

\subsection{Turnera annularis Urb., Jahrb. Königl. Bot. Gart.}

Berlin 2: 124. 1883.

Figuras 6C-H e 26; Arbo (2000: fig. 1A-J).

Arbustos ou subarbustos $0,5-2 \mathrm{~m}$ alt; caules glabrescentes, porção termianl denso-pilosa, tricomas tectores simples e glandulares capitado-sésseis. Estípulas 2, 1,5-5 mm compr. Folhas com pecíolo 210 mm compr.; nectários 3-4 pares, 0,3-0,7 mm diâm.; lâmina 2-8,3 × 1-3,3 cm, papirácea, concolor, ovada, elíptica a obovada, base cuneada, ápice agudo a obtuso, margens serreado-crenadas, planas; face adaxial esparso-estrigosa, nervuras impressas, face abaxial esparso-pilosa, nervuras proeminentes. Inflorescências em racemos terminais, abreviados, capituliformes; 
pedúnculo 0,5-2 mm compr., livre do pecíolo; brácteas 3-7 $\times$ 1,5-4 mm, ovadas a obovadas, nectários ausentes; bractéolas 3-7 mm compr., obovadas. Flores heterostilas; pedicelo ausente. Cálice 5-8 $\mathrm{mm}$ compr., externamente glabro na base, lacínios esparso-pilosos. Corola 6-9 mm compr., branca, base das pétalas amarela, unha desprovida de apêndice. Filetes 5-6 mm compr. em flores brevistilas, 3-4,5 $\mathrm{mm}$ compr. em flores longistilas, ápice esparso-piloso, base achatada, 1,3-1,5 $\mathrm{mm}$ adnata ao tubo floral; anteras 0,7-1,5 $\mathrm{mm}$ compr., dorsifixas. Ovário 1-1,5 mm compr., densopiloso apenas no ápice; estiletes $2-3 \mathrm{~mm}$ compr. em flores brevistilas, 4-6,5 $\mathrm{mm}$ compr. em flores longistilas, base denso-pilosa; estigmas penicelados. Cápsulas 4-5 mm diâm.; epicarpo liso, ápice densopiloso. Sementes 1,5-2 × 1-1,4 mm, obovoides, retas, reticuladas; epiderme papilosa; calaza proeminente, superfície côncava.

Ocorre no Nordeste (Bahia, Pernambuco e Paraíba) e Sudeste (Minas Gerais e Rio de Janeiro) (Arbo 2000, 2015). E6, G8/9: matas higrófilas. Encontrada em áreas de várzea de rios e em pastagens. Apresenta flores e frutos em abril, junho e dezembro.

Material selecionado - Itacaré, entrada a ca. $1 \mathrm{~km}$ da BR-101, na estrada para Itacaré, ca. $10 \mathrm{~km}$ da entrada, $14^{\circ} 16^{\prime} 38^{\prime \prime} \mathrm{S}$, 3859'48"W, 6 abr. 1997 (fl., fr.), J.G. Jardim 1032 (ALCB, CTES, HUEFS, MBM, NY-foto); Lençóis, Marimbus, 1240'57"S, 4120'22"W, 320 m, 13 dez. 2002 (fl., fr.), F. França et al. 3909 (CTES, HUEFS).

Pode ser reconhecida pelas folhas serreadocrenadas e inflorescências em racemos abreviados, com flores de cálice externamente glabro na base e corola branca, com base das pétalas amarela. As sementes apresentam uma depressão puntiforme em cada aréola. Devido ao hábito arbustivo e às inflorescências capituliformes, $T$. annularis se assemelha a $T$. albicans, a qual se diferencia pelas folhas geralmente maiores, com margens serrilhadas, e as flores sésseis.

\subsection{Turnera asymmetrica Arbo, Bonplandia 10: 43} 2000

Figuras 7A-B e 27; Arbo (2000: 15A-H).

Arbustos ca. $1 \mathrm{~m}$ alt.; caules denso-pilosos, tricomas tectores simples e tricomas glandulares capitado-sésseis. Estípulas 2, 0,2-0,3 mm compr. Folhas com pecíolo até $1 \mathrm{~mm}$ compr.; nectários ausentes; lâmina 10-25 × 4-8 mm, papirácea, discolor, obovada a elíptica, base atenuada a cuneada, ápice agudo a obtuso, margens serreadas, planas ou revolutas, 1-4 pares de dentes em cada lado da lâmina; face adaxial esparso-pilosa, nervuras impressas, face abaxial denso-pilosa, nervuras proeminentes. Inflorescências unifloras, solitárias ou agrupadas no ápice dos ramos; pedúnculo 4-11 mm compr., 1-2 mm adnato ao pecíolo; brácteas ausentes; bractéolas 6-11 mm compr., ovadas, assimétricas. Flores heterostilas; pedicelo ausente. Cálice 9-11 $\mathrm{mm}$ compr., externamente esparso-piloso. Corola 7-10 mm compr., amarela, base das pétalas púrpura. Filetes ca. $6,5 \mathrm{~mm}$ compr. em flores brevistilas, ca. $3 \mathrm{~mm}$ compr. em flores longistilas, glabros, base ca. $0,5 \mathrm{~mm}$ adnata ao tubo floral; anteras 1,5-1,8 $\mathrm{mm}$ compr., dorsifixas. Ovário ca. 2,5 mm compr., tomentoso; estiletes ca. 1,3 $\mathrm{mm}$ compr. em flores brevistilas, ca. $3 \mathrm{~mm}$ compr. em flores longistilas, glabros; estigmas penicelados. Cápsulas 5-6 mm diâm.; epicarpo granuloso, esparsopiloso. Sementes ca. $2 \times 1,2 \mathrm{~mm}$, obovoides, ligeiramente curvas, reticuladas; epiderme lisa; calaza pouco proeminente, superfície côncava.

Rara, provavelmente endêmica da região centro-sul da Bahia (Arbo 2000; Arbo \& Giulietti 2009). G6: cerrados. Encontrada em área perturbada, na margem da rodovia, com flores e frutos em novembro.

Material examinado - Tanhaçu, $1 \mathrm{~km} \mathrm{~S}$ de Tanhaçu, estrada para Brumado, $14^{\circ} 02^{\prime} \mathrm{S}, 41^{\circ} 15^{\prime} \mathrm{W}, 420 \mathrm{~m}, 22$ nov. 1992 (fl., fr.), M.M. Arbo et al. 5694 (holótipo SPF, isótipos CEN, CTES, HUEFS, IPA, K-foto, MBM, NY-foto, RB, UB).

Pode ser reconhecida pelas folhas serreadas, bractéolas ovadas, assimétricas, além das flores de corola amarela, com base das pétalas púrpura. As sementes apresentam uma depressão puntiforme em cada aréola. Arbo (2000) se referiu às suas flores como aparentemente homostilas, mas pudemos confirmar que são heterostilas. Turnera asymmetrica apresenta hábito semelhante a $T$. chamaedrifolia, a qual se diferencia pelo indumento com tricomas capitado-estipitados e bractéolas linear-triangulares.

\subsection{Turnera bahiensis Urb., Repert. Spec. Nov. Regni} Veg. 4: 134. 1907

Figuras 7C-E e 27; Arbo (2005: figs 6A-N e 8A-M); Rocha \& Moreira (2014: fotos 28-30).

Arbustos 1-4 m alt.; caules denso-estrigosos a glabrescentes, tricomas tectores simples. Estípulas 2, 1-2,5 mm compr. Folhas com pecíolo 2-14 $\mathrm{mm}$ compr.; nectários 1-3 pares, 0,3-0,6 mm diâm.; lâmina $1,5-8,5 \times 0,6-3,0 \mathrm{~cm}$, cartácea, discolor, ovada, elíptica a obovada, base cuneada, ápice agudo a obtuso, margens serreado-crenadas a crenadas, revolutas; face adaxial estrigosa, nervuras impressas, face abaxial geralmente tomentosa, nervuras proeminentes. Inflorescências em capítulos terminais; pedúnculo ausente; brácteas 1-1,5 × 0,6$0,7 \mathrm{~cm}$, estreito-ovadas, até 4 pares de nectários, $0,5-$ 1,4 mm diâm.; bractéolas 4-6 mm compr., estreitoobovadas, ápice agudo truncado, ligeiramente mucronado. Flores heterostilas; pedicelo ausente. Cálice 7,5-12 $\mathrm{mm}$ compr., externamente densopiloso. Corola 1-2 cm compr., amarela. Filetes 5-9 mm compr. em flores brevistilas, 3-4 mm compr. em flores longistilas, ápice esparso-piloso, margens 2-4 $\mathrm{mm}$ adnatas a unha das pétalas, formando sacos nectaríferos; anteras 1-1,5 $\mathrm{mm}$ compr., dorsifixas. Ovário 2-4 mm compr., tomentoso; estiletes 2-3 mm compr. em flores brevistilas, 4-5 mm compr. em flores longistilas, esparso ou denso-pilosos; estigmas penicelados. Cápsulas 6-10 $\mathrm{mm}$ diâm.; epicarpo 
granuloso, tomentoso-hirsuto. Sementes 2,5-3,4 $\times 1-$ epiderme papilosa; calaza proeminente, superfície 1,5 mm, obovoides, retas, estriado-reticuladas; ligeiramente côncava.
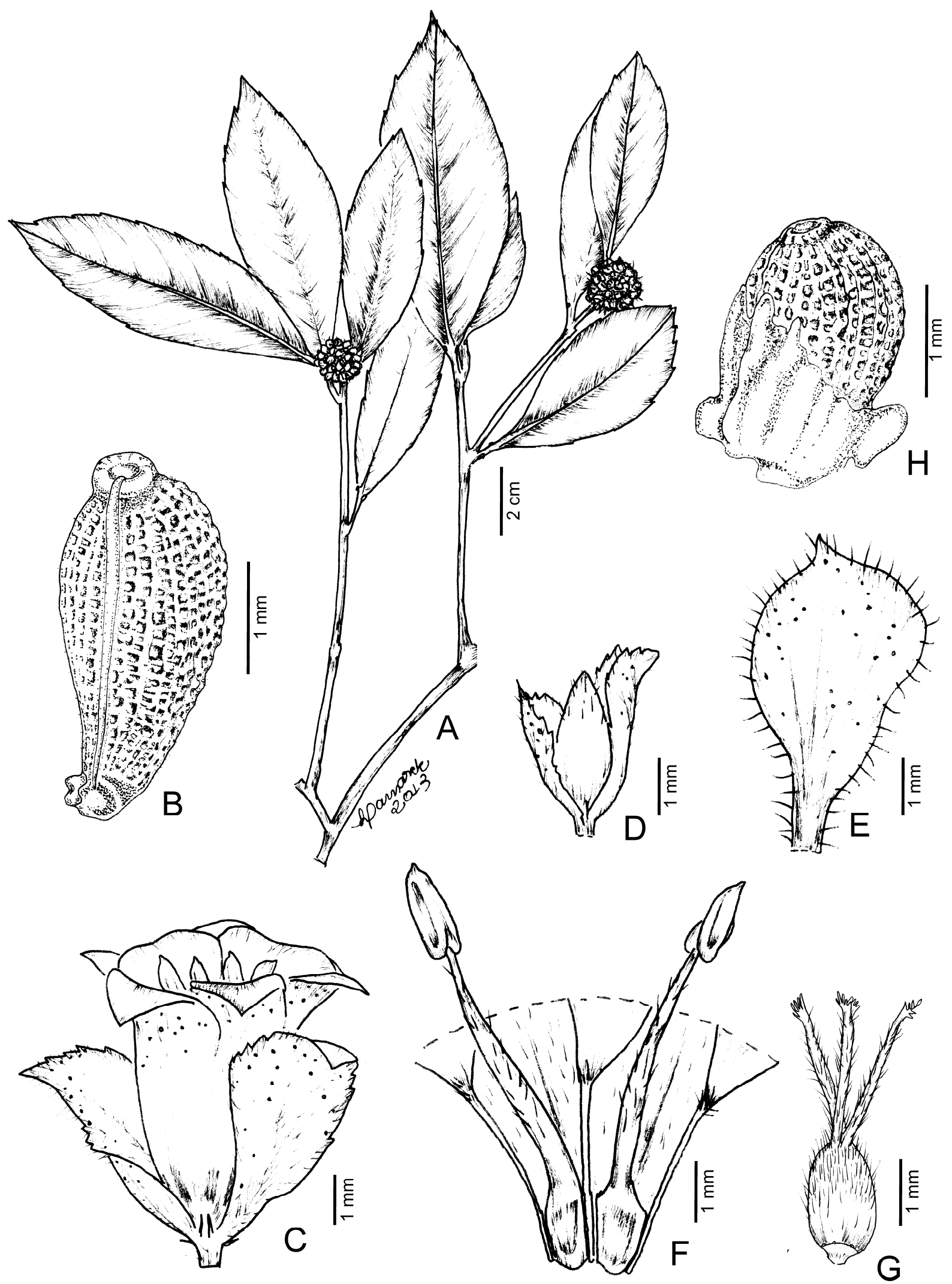

Figura 6. A, B. Turnera albicans: A- ramo reprodutivo; B- semente (A- Matos-Silva 1414; B- Jardim 4632). C-H. T. annularis: C- flor; D- botão com bractéolas; E- bráctea (face adaxial); F- flor dissecada evidenciando parte do androceu (flor brevistila); G- gineceu (flor brevistila); H- semente (C-H- França 3909). 

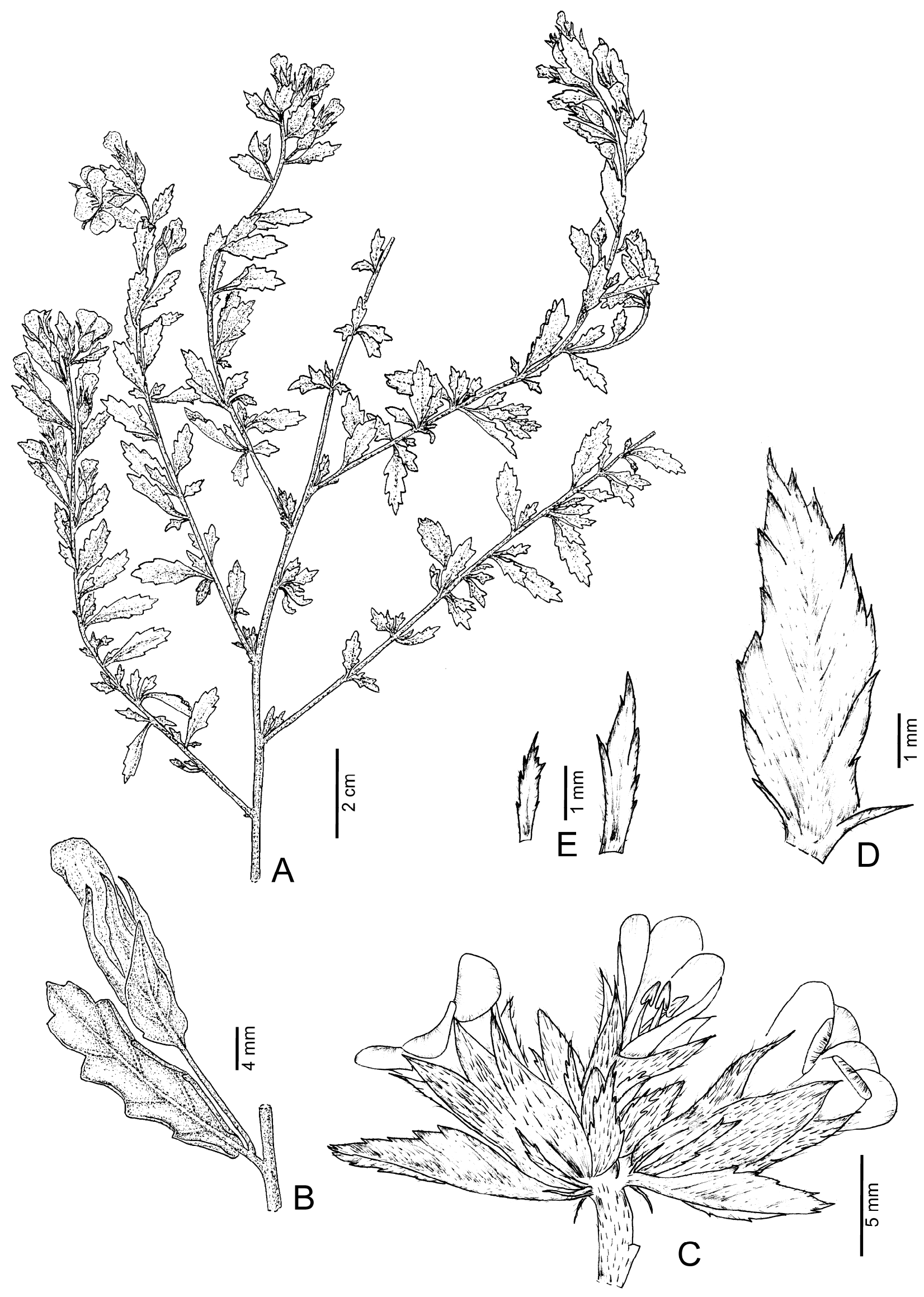

Figura 7. A, B. Turnera asymmetrica: A- ramo reprodutivo; B- flor com bractéola (Arbo 5694). C-E. T. bahiensis: C- inflorescência; D- bráctea (face adaxial); E- bractéolas (face adaxial) (França 3973) (A, B por Liliana Gomes). 
Ocorre nos estados da Bahia, Ceará e Piauí (Arbo 2015). C8, D6/7, E2/3, E/F5, E6, F6, G3, G6: caatingas, cerrados, capoeiras, campos rupestres e matas ciliares. Habita áreas abertas ou sombreadas, às vezes perturbadas, como margens de rodovias. Cresce em substratos argilosos, arenosos ou rochosos, em altitudes de 400-1300 m. Apresenta flores e frutos durante o ano todo.

Material selecionado - Anagé, Serra do Sincorá, 143' $\mathrm{S}$, 410' 'W, 6 mar. 1996 (fl., fr.), F.R.G. Salimena \& P.H. Nobre 367 (CTES); Andaraí, ca. $2 \mathrm{~km}$ da entrada de Igatu, 1256'55"S, 4117'05"W, 840 m, 23 set. 2005 (fl., fr.), M.G. Bovini et al. 2492 (CTES, HUEFS, RB); Barra da Estiva, $22 \mathrm{~km} \mathrm{NE}$ de Barra da Estiva, $2 \mathrm{~km}$ antes de Sincorá Velho, $13^{\circ} 31^{\prime} \mathrm{S}, 41^{\circ} 14^{\prime} \mathrm{W}, 890 \mathrm{~m}, 23$ nov. 1992 (fl., fr.), M.M. Arbo et al. 5753 (CTES, HUEFS, SPF, RB, UB); Barreiras, vale do rio das Ondas, Espigão Mestre, próximo ao aeroporto de Barreiras, ca. $5 \mathrm{~km} \mathrm{NE}$ de Barreiras, $12^{\circ} 09^{\prime} 10^{\prime \prime} \mathrm{W}, 44^{\circ} 59^{\prime} 24^{\prime \prime} \mathrm{W}, 650$ m, 4 mar. 1971 (fl., fr.), H.S. Irwin et al. 31476 (UB); Bonito, mata de Capão das Antas, 7,3 km sul de Bonito na estrada para Utinga, $12^{\circ} 01^{\prime} 37^{\prime \prime S}, 41^{\circ} 13^{\prime} 57^{\prime \prime} \mathrm{W}, 790-820$ m, 12 mar. 2002 (fl., fr.), W.W. Thomas et al. 12938 (CEPEC, CTES, SP); Contendas do Sincorá, Capão de Sincorá, aprox. $13^{\circ} 45^{\prime} \mathrm{W}, 41^{\circ} 02^{\prime} \mathrm{S}, 900 \mathrm{~m}$, set. 1906 (fl., fr.), E. Ule 7302 ([var. bahiensis] holótipo HBG-foto, isótipo K-foto); Lençóis, $12^{\circ} 34^{\prime} \mathrm{S}$, $41^{\circ} 23^{\prime} \mathrm{W}, 600$ m, 17 mar. 2007 (fl.), A.P.L. Couto 218 (CTES, HUEFS); Macaúbas, estrada para Canatiba, Serra Poções, próximo ao alto, $13^{\circ} 01^{\prime} \mathrm{S}, 42^{\circ} 41^{\prime} \mathrm{W}, 1100 \mathrm{~m}, 18$ jan. 1997 (fl., fr.), G. Hatschbach et al. 65966 ([var. truncata] holótipo MBM, isótipos CTES, K-foto); Morro do Chapéu, Trilha entre o rio Ferro Doido e a Estrada do Feijão (BA 052), 11'37'09"S, 4059'28"W, 748-760 m, 29 jan. 2003 (fl., fr.), F. França et al. 4049 (CTES, HUEFS); Mucugê, fazenda Caraibas, $13^{\circ} 08^{\prime} 98^{\prime \prime} \mathrm{S}, 41^{\circ} 24^{\prime} 85^{\prime \prime} \mathrm{W}, 12 \mathrm{dez} .2004$ (fl., fr.), M.T.S. Stradmann \& P. Castilho 1114 a (ALCB, CEPEC); Palmeiras, $5 \mathrm{~km} \mathrm{~L}$ de Campo de São Paulo, 12²7'39"S,

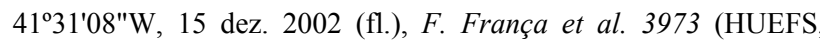
BHCB); Quijingue, Serra da Gameleira, encosta, 1045'10"S, 39¹2'36W, 24 out. 1970 (fl., fr.), G.C.P. Pinto s.n. (IPA 21897); São Félix do Coribe, Ponta d'Água em direção a Coribe/Descoberto,

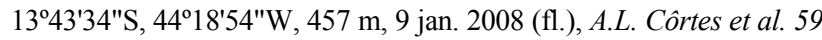
(HUEFS); Seabra, Serra da Água de Rega, ca. $1 \mathrm{~km} \mathrm{~N}$ de Água de Rega, estrada para Cafarnaum, $12^{\circ} 28^{\prime} \mathrm{S}, 41^{\circ} 44^{\prime} \mathrm{W}, 1000 \mathrm{~m}, 28$ fev. 1971 (fl., fr.), H.S. Irwin et al. 31248 (UB).

Pode ser reconhecida pelo indumento composto apenas por tricomas simples; inflorescências em capítulos globosos, com brácteas estreito-ovadas ou elípticas, às vezes com nectários chamativos na base. Os espécimes geralmente adquirem uma coloração castanho-avermelhada quando secos. Turnera bahiensis se assemelha vegetativamente a $T$. blanchetiana, a qual se diferencia pelo indumento com tricomas estrelados e brácteas subcirculares.

Arbo (2005) considerou duas variedades nesta espécie: T. bahiensis var. bahiensis e T. bahiensis var. truncata Arbo, ambas ocorrentes na Bahia. A variedade típica pode ser reconhecida pelas bractéolas com ápice agudo, ocorrente apenas na Bahia, principalmente na Chapada Diamantina; T. bahiensis var. truncata se diferencia pelas bractéolas com ápice truncado, ligeiramente mucronado, sendo conhecida para a região oeste da Bahia, Ceará e Piauí.
2.5. Turnera blanchetiana Urb., Jahrb. Königl. Bot. Gart. Berlin 2: 130. 1883.

Figuras 8 e 28; Arbo (2005: fig. 9A-N); Rocha \& Moreira (2014: fotos 31-33).

Arbustos a subarbustos 0,4-3 m alt.; caules tomentosos a glabrescentes, tricomas tectores estrelados e simples. Estípulas 2, 0,5-1 mm compr. Folhas com pecíolo 5-10 mm compr.; nectários até 2, ca. 0,5 $\mathrm{mm}$ diâm; lâmina 2,1-7,6 × 1,2-4,5 cm, cartácea, discolor; ovada, elíptica, largo-elíptica a obovada, base cuneada ou arredondada, ápice agudo a obtuso, margens duplamente crenadas a serreado-crenadas, planas ou ligeiramente revolutas; face adaxial denso-pilosa, nervuras impressas, face abaxial tomentosa, nervuras proeminentes. Inflorescências em capítulos terminais; pedúnculo ausente; brácteas 3,5-8 $\times 2,5-6 \mathrm{~mm}$, subcirculares, nectários ausentes; bractéolas 3,5-5 mm compr., obovadas. Flores heterostilas; pedicelo ausente. Cálice 6-8 mm compr., externamente tomentoso. Corola 1-1,9 cm, amarela. Filetes 4,5-7 mm compr. em flores brevistilas, 3-4 mm em flores longistilas, ápice esparsopiloso, margens 2-3 $\mathrm{mm}$ adnatas à unha das pétalas, formando sacos nectaríferos; anteras 1-1,5 mm compr., dorsifixas. Ovário 1,5-2 mm diâm., tomentoso; estiletes 1,5-2 mm compr. em flores brevistilas, 3,5-4,5 $\mathrm{mm}$ compr. em flores longistilas, pilosos; estigmas penicelados. Cápsulas 5-9 $\mathrm{mm}$ diâm.; epicarpo granuloso, tomentoso-hirsuto. Sementes 2-3 $\times 1-1,5$ $\mathrm{mm}$, largo-obovoides, ligeiramente curvas, estriadoreticuladas; epiderme papilosa; calaza proeminente, superfície côncava.

Ocorre predominantemente no Nordeste (Piauí, Ceará, Rio Grande do Norte, Paraíba, Pernambuco e Bahia) e norte de Minas Gerais (Arbo 2015). B5, B6, B7, B9, C5, C6, C7, D5, D6, D7, E4, E6, F4, F5, F6, F7, G5, G6: caatingas, cerrados, campos rupestres e florestas estacionais semideciduais. Ocorre principalmente na região central do Estado, habitando terrenos baldios, margens ribeirinhas, afloramentos rochosos ou margens de trilhas e rodovias, em altitudes até $1200 \mathrm{~m}$. Apresenta flores e frutos durante o ano todo.

Material selecionado - Andaraí, próximo à cidade, $12^{\circ} 48^{\prime} \mathrm{S}$, 41ํ2'W, 850 m, 16 dez. 2009 (fl.), M.L. Guedes et al. 16846 (ALCB, FMB-foto, HUEFS); Barra da Estiva, 10-15 km a W de Capão de Volta, estrada para Jussiape, $13^{\circ} 30^{\prime} \mathrm{S}, 41^{\circ} 30^{\prime} \mathrm{W}, 1100-1200 \mathrm{~m}, 20$ jan. 1997 (fl., fr.), M.M. Arbo et al. 7585 (CEPEC, CTES); Barra do Mendes, ca. 17,5 km do povoado de São Bento, estrada para Torre,

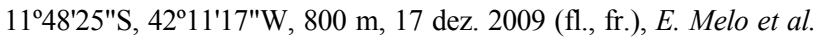
7653 (ALCB, HUEFS); Bom Jesus da Lapa, a estrada de Terra, em direção a Macaúbas, Lagoa do Alto, 1309'52"S, 430'ㄹ' $28^{\circ} \mathrm{W}, 453$ m, 12 jan. 2008 (fl.), U.C.S. Silva et al. 14 (HUEFS); Cafarnaum, fazenda Cachoeira, $12^{\circ} 00^{\prime} \mathrm{S}, 41^{\circ} 32^{\prime} \mathrm{W}, 800 \mathrm{~m}, 17$ mar. 1984 (fl.), $A$. Salgado-Odilon \& H.P. Bautista 262 (ALCB, HRB, RB); Casa Nova,

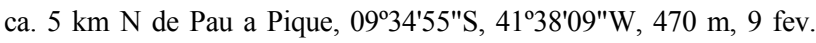
2004 (fl., fr.), L.P. Queiroz et al. 9119 (HUEFS); Contendas do Sincorá, entre Sussuarana e Contendas do Sincorá, ao lado da portaria da fazenda Vargem Grande, 135'ㄱ' $35^{\prime \prime S}, 41^{\circ} 05^{\prime} 49^{\prime \prime} \mathrm{W}, 28$ fev. 1999 (fl.), R.M. Harley \& A.M. Giulietti 53463 (CEPEC, HUEFS); Ibipeba, estrada para Barro Alto, ca. $2,5 \mathrm{~km}, 11^{\circ} 47^{\prime} 17^{\prime \prime S}$, 


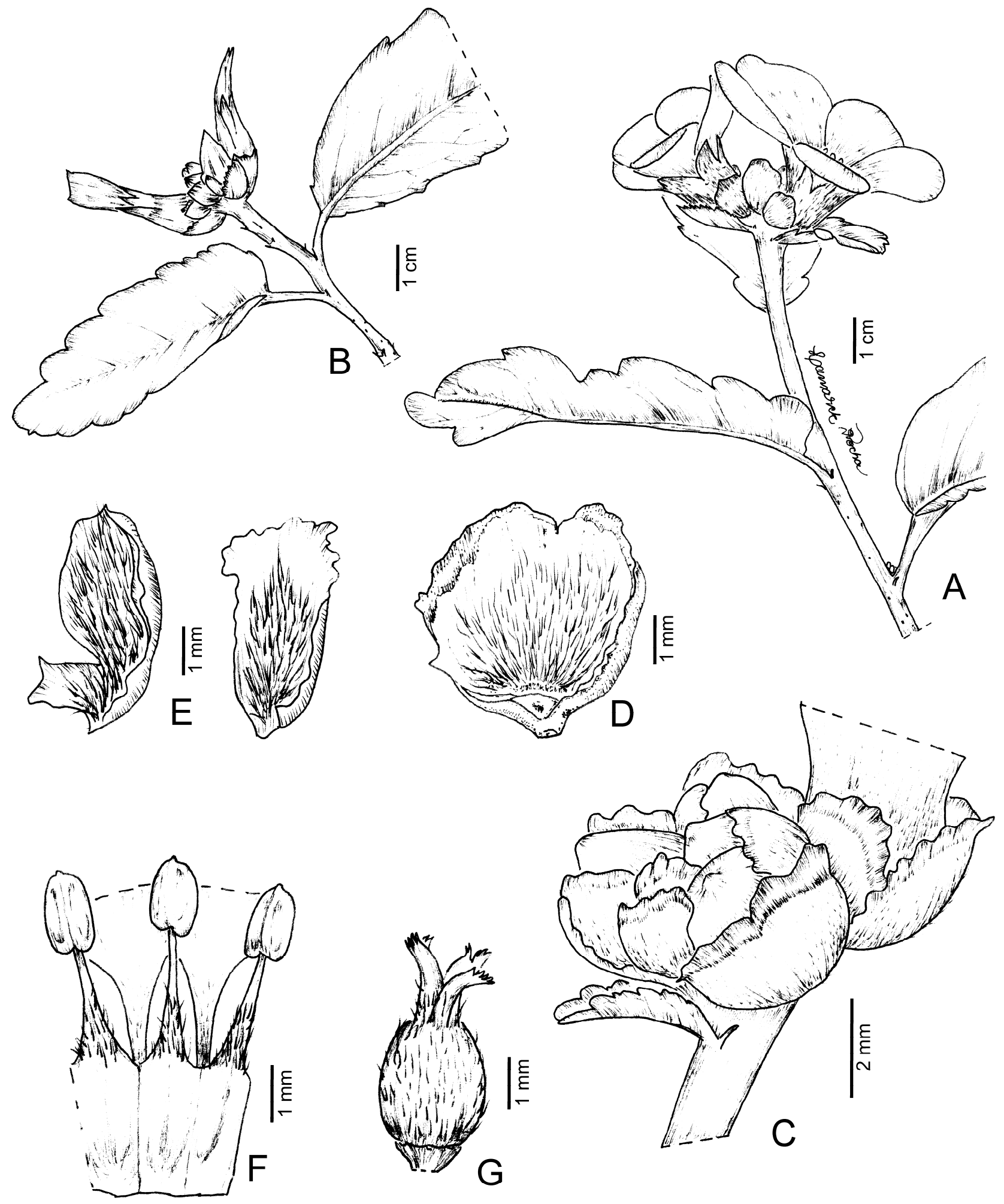

Figura 8. Turnera blanchetiana: A, B- ramos reprodutivos; C- inflorescência; D- bráctea (face adaxial); E- bractéolas (face adaxial); F- flor dissecada evidenciando parte androceu (flor brevistila); G- gineceu (Rocha 411).

4202'15"W, 767 m, 15 dez. 2009 (fl.), E. Melo et al. 7530 (ALCB, HUEFS); Igaporã, estrada para Tanque Novo, $13^{\circ} 44^{\prime} 23^{\prime \prime} \mathrm{S}$,

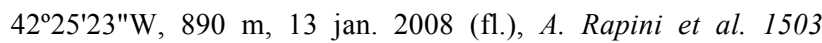
(HUEFS); Itaberaba, Pasto Tanque, fazenda Serra da Monta, $12^{\circ} 31^{\prime} 40^{\prime \prime} \mathrm{S}, 40^{\circ} 18^{\prime} 25^{\prime \prime} \mathrm{W}, 9$ mar. 1982 (fl., fr.), B.C. Bastos 289
(HRB); Itiúba, $22 \mathrm{~km}$ a $\mathrm{W}$ de Itiúba, estrada para Filadélfia, $10^{\circ} 43^{\prime} \mathrm{S}, 40^{\circ} 03^{\prime} \mathrm{W}, 400 \mathrm{~m}, 16$ jan. 1997 (fl., fr.), M.M. Arbo et al. 7324 (CEPEC, CTES, HUEFS); Juazeiro, 7 km S de Juazeiro na BR-407 para Senhor do Bonfim, 09 $25^{\circ} \mathrm{S}, 40^{\circ} 35^{\prime} \mathrm{W}, 24$ jan. 1993 (fl.), W. Thomas et al. 9623 (CEPEC); Lençóis, Mata das Toalhas, 
$12^{\circ} 30^{\prime} 25^{\prime \prime S}, 41^{\circ} 22^{\prime} 23^{\prime \prime W}, 450$ m, 26 mar. 2000 (fl.), L.S. Funch \& R. Funch 1123a (HUEFS); Licínio de Almeida, $2 \mathrm{~km}$ antes da entrada da cidade, $14^{\circ} 53^{\prime} \mathrm{S}, 42^{\circ} 53^{\prime} \mathrm{W}, 10$ jan. 2006 (fl., fr.), T.S. Nunes et al. 1657 (HUEFS, CTES); Livramento do Brumado, 3 $5 \mathrm{~km}$ da cidade na estrada para Rio de Contas, $13^{\circ} 38^{\prime} \mathrm{S}, 41^{\circ} 50^{\prime} \mathrm{W}$, 580-600 m, 12 dez. 1988 (fl., fr.), R.M. Harley et al. 27145 (CEPEC, CTES, SPF); Macaúbas, BR-168, próximo ao trevo para Macaúbas, $13^{\circ} 01$ 'S, $42^{\circ} 41^{\prime} \mathrm{W}, 30$ nov. 2004 (fl., fr.), $G$. Hatschbach et al. 78678 (CTES, MBM); Maracás, ca. 6 km SW da cidade, $13^{\circ} 44^{\prime} \mathrm{S}, 40^{\circ} 43^{\prime} \mathrm{W}$, jan. 1988 (fl., fr.), M. Sobral \& L.A. Mattos-Silva 5888 (CEPEC, CTES, MBM); Marcionílio Souza, $11 \mathrm{~km} \mathrm{~W}$ da cidade, na estrada para Itaetê, $13^{\circ} 03^{\prime} \mathrm{S}, 40^{\circ} 35^{\prime} \mathrm{W}, 305$ m, 22 mar. 1988 (fl., fr.), S. Ginzbarg et al. 808 (CEPEC, CTES); Milagres, $24 \mathrm{~km} \mathrm{~S}$ da cidade, $12^{\circ} 52^{\prime} \mathrm{S}, 39^{\circ} 51^{\prime} \mathrm{W}, 30$ jan. 1963 (fl., fr.), A. Krapovickas 10091 (CTES, MBM); Morro do Chapéu, BA-52, a $22 \mathrm{~km}$ da cidade, $11^{\circ} 29^{\prime} 25^{\prime \prime} \mathrm{S}, 41^{\circ} 20^{\prime} 17^{\prime \prime} \mathrm{W}, 890 \mathrm{~m}, 21$ jan. 2009 (fl.), F.S. Gomes et al. 97 (ALCB, MBM); Palmeiras,

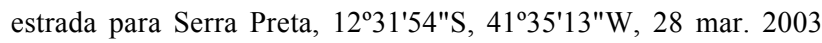
(est.), E. Melo et al. 3612 (HUEFS); Paulo Afonso, Raso da Catarina, 09 $04^{\prime} \mathrm{S}, 38^{\circ} 22^{\prime} \mathrm{W}, 10$ nov. 2010 (fl., fr.), E. Barbosa et al. 2871 (MBM); Remanso, estrada Petrolina-Remanso, $09^{\circ} 37^{\prime} \mathrm{S}$, 42 $04^{\prime} \mathrm{W}, 25$ abr. 1971 (fl., fr.), E.P. Heringer et al. 358 (IPA, RB, UB); Seabra, BR-242, 12 $28^{\prime} \mathrm{S}, 4^{\circ} 44^{\prime} \mathrm{W}, 14$ mar. 1984 (f1.), $A$. Salgado-Odilon 369 (CEPEC, HRB, RB); Senhor do Bonfim, Serra da Maravilha, 10²4'16"S, 40²'12'36"W, 739 m, 28 jul. 2005 (fr.), R.M. Castro et al. 1270 (HUEFS); Sento Sé, $8 \mathrm{~km}$ da cidade, 09 $43^{\prime} 22^{\prime \prime S}, 41^{\circ} 57^{\prime} 32^{\prime \prime W}, 520$ m, 26 jan. 2008 (fl.), C. Correia et al. 401 (HUEFS); Tanhaçu, 1-2 km a SE de Tanhaçu, $14^{\circ} 02^{\prime} \mathrm{S}$,

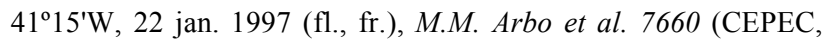
CTES); Umburanas, final da estrada para a comunidade do Rodoleiro, 10³6'17"S, 41'31'21"W, 1030 m, 27 jan. 2010 (fl., fr.), D. Araújo et al. 1254 (HVASF); Várzea Nova, BA-426, 7 km a SW da cidade, estrada para Morro do Chapéu, $11^{\circ} 18^{\prime} \mathrm{S}, 40^{\circ} 58^{\prime} \mathrm{W}$, 17 jan. 1997 (fl., fr.), M.M. Arbo et al. 7434 (CEPEC, CTES, RB); Vitória da Conquista, margem do Riachão do Poço, $14^{\circ} 52^{\prime} \mathrm{S}$, $41^{\circ} 04^{\prime} \mathrm{W}, 30$ mar. 1984 (fl.), L.C. Oliveira-Filho \& J.C.A. Lima 141 (CEPEC, HRB, MBM, RB); Wanderley, $12^{\circ} 07^{\prime} \mathrm{S}, 43^{\circ} 53^{\prime} \mathrm{W}$, 30 nov. 2011 (fl.), A.M. Miranda \& J. Ferraz 6452 (HST); XiqueXique, $15 \mathrm{~km}$ ao $\mathrm{S}$ da cidade, estrada para Santo Inácio, $10^{\circ} 58^{\prime} \mathrm{S}$, 4241'W, 400-500 m, 19 jan. 1997 (fl.), M.M. Arbo et al. 7528 (CEPEC, CTES).

Pode ser reconhecida pelas flores sésseis reunidas em capítulos globosos, além das brácteas subcirculares. Turnera blanchetiana se assemelha a $T$. bahiensis, a qual se diferencia pelo indumento apenas com tricomas simples e brácteas estreito-ovadas. É corriqueiramente identificada como $T$. cearensis, que pode ser diferenciada pelas flores solitárias, pedunculadas, às vezes agrupadas em braquiblastos, e desprovidas de brácteas.

Arbo (2005) admitiu duas variedades para a espécie: T. blanchetiana var. blanchetiana e $T$. blanchetiana var. subspicata Urb.; apenas a variedade típica ocorre na Bahia. Turnera blanchetiana var. subspicata ocorre na Bolívia, Paraguai e Centro-Oeste do Brasil (Mato Grosso e Mato Grosso do Sul) (Arbo 2005, 2015), pode ser reconhecida pelas flores reunidas em racemos espiciformes (vs. capítulos, na variedade típica).
2.6. Turnera caatingana Arbo, Bonplandia 10: 66. 2000.

Figuras 28; Arbo (2000: fig. 19A-I).

Arbustos 0,4-1,2 m alt.; caules hirsutos, porção terminal denso-hirsuta, tricomas tectores simples e glandulares capitado-estipitados. Estípulas reduzidas a 2 ou 3 pares de coléteres. Folhas com pecíolo 3-20 mm compr.; nectários ausentes; lâmina 2,5-10 × 1,3$5,3 \mathrm{~cm}$, papirácea, discolor, ovada a elíptica, base atenuada a cuneada, ápice agudo, margens serreadocrenadas, ligeiramente revolutas; face adaxial setosoestrigosa, nervuras impressas, face abaxial vilosa, nervuras poeminentes. Inflorescências unifloras; solitárias; pedúnculo 5-10 mm compr., livre ou ca. 1,5 $\mathrm{mm}$ adnato ao pecíolo; brácteas ausentes; bractéolas 8 $15 \mathrm{~mm}$ compr., linear-lanceoladas. Flores heterostilas; pedicelo até $1 \mathrm{~mm}$ compr. Cálice 1-1,4 cm compr., externamente viloso. Corola 1,3-1,7 cm compr., creme. Filetes 3-4,5 mm compr. em flores brevistilas, 4-4,5 $\mathrm{mm}$ compr. em flores longistilas, glabros, base ca. 0,5 $\mathrm{mm}$ adnata ao tubo floral; anteras 2-3 $\mathrm{mm}$ compr., dorsifixas. Ovário 2-3,5 $\mathrm{mm}$ compr., tomentosohirsuto; estiletes 2,5-3 $\mathrm{mm}$ compr. em flores brevistilas, ca. $6 \mathrm{~mm}$ compr. em flores longistilas, glabros; estigmas penicelados. Cápsulas ca. $5 \mathrm{~mm}$ diâm.; epicarpo granuloso, hirsuto. Sementes 1,5-2,2 $\times$ 0,7-1 mm, obovoides, ligeiramente curvas, reticuladas; epiderme lisa; calaza obtusa, superfície plana.

Rara, endêmica do sudoeste da Bahia (Arbo \& Giulietti 2009). F6, G5: caatingas e matas de cipó. Coletada em local perturbado, na margem de rodovia, em altitudes de 500-900 m. Apresenta flores e frutos em novembro, fevereiro e janeiro. Medidas baseadas em Arbo (2000).

Material selecionado - Abaíra, ca. $5 \mathrm{~km}$ a SW de Abaíra, ao

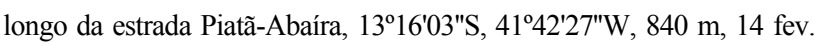
1992 (fl., fr.), L.P. Queiroz 2611 (HUEFS); Caetité, $20 \mathrm{~km}$ a E de Caetité, estrada para Brumado, 14 $08^{\prime} \mathrm{S}, 42^{\circ} 15^{\prime} \mathrm{W}, 500 \mathrm{~m}, 20$ nov. 1992 (fl.), M.M. Arbo et al. 5645 (holótipo SPF, isótipos CTES, HUEFS).

Pode ser reconhecida pelas folhas e pedúnculos florais bem desenvolvidos, além dos caules tomentosohirsutos no ápice, com tricomas esbranquiçados. $T$. caatingana se assemelha à $T$. chamaedrifolia, a qual se diferencia pelas flores com pétalas creme de base vinácea e folhas geralmente menores.

\subsection{Turnera calyptrocarpa Urb., Jahrb. Königl. Bot.} Gart. Berlin 2: 128. 1883.

Figuras 9A-D e 29; Arbo (2000: fig. 16A-H); Rocha \& Moreira (2014: foto 34).

Subarbustos ou arbustos 0,2-2 m alt.; ramos denso-pilosos a glabrescentes, tricomas tectores simples e glandulares capitado-sésseis. Estípulas 2, 2-4 $\mathrm{mm}$ compr. Folhas às vezes arranjadas em braquiblastos terminais; pecíolo 2-4 $\mathrm{mm}$ compr.; nectários ausentes; lâmina 5-33 × 2-18 mm, cartácea, discolor, obovada, elíptica, raro ovada, base cuneada a atenuada, ápice agudo a obtuso, margens serreadocrenadas quase até a base, revolutas; face adaxial 
esparso-pilosa a estrigosa, nervuras impressas, face abaxial vilosa, nervuras proeminentes. Inflorescências unifloras, solitárias; pedúnculo 1-4 mm compr., livre do pecíolo; brácteas ausentes; bractéolas 2-6 $\mathrm{mm}$ compr., obovadas a espatuladas. Flores heterostilas; pedicelo ausente. Cálice 4,5-5 $\mathrm{mm}$ compr., externamente estrigoso a hirsuto. Corola 5-13 $\mathrm{mm}$ compr., branca, base das pétalas amarela. Filetes 5-6 $\mathrm{mm}$ compr. em flores brevistilas, 2-3 $\mathrm{mm}$ compr. em flores longistilas, esparso-pilosos, base $0,2-0,5 \mathrm{~mm}$ adnata ao tubo floral; anteras $0,5-1 \mathrm{~mm}$ compr., dorsifixas. Ovário 1,2-2 mm compr., hirsuto; estiletes 1,3-1,7 mm compr. em flores brevistilas, 3,5-5 $\mathrm{mm}$ compr. em flores longistilas, glabros a esparso-pilosos; estigmas brevemente penicelados. Cápsulas 4-7 $\mathrm{mm}$ diâm.; epicarpo granuloso, hirsuto. Sementes 1,7-2 $\times$ ca. 1,2 mm, obovoides, ligeiramente curvas, reticuladas; epiderme papilosa; calaza obtusa, superfície ligeiramente côncava.

Ocorre em todos os estados nordestinos, até Minas Gerais (Arbo 2015). B7, B9, C7, C8, D3, C/D3, D7, D9, D10, E6, E7, E8, E9, F6, G5: caatingas e restingas. Habita áreas abertas, por vezes terrenos baldios, além de encostas e margens de rodovias. Cresce em substratos arenosos, argilosos ou rochosos, em altitudes até ca. $1000 \mathrm{~m}$. Apresenta flores e frutos o ano todo.

Material selecionado - Alagoinhas, $12^{\circ} 12^{\prime} \mathrm{S}, 38^{\circ} 43^{\prime} \mathrm{W}, 14 \mathrm{fev}$. 1980 (f1.), G.C.P. Pinto 20/80 (CEPEC, HRB); Caetité, Brejinho das Ametistas, $1^{\circ}{ }^{\circ} 5^{\prime} 37^{\prime \prime} \mathrm{S}, 4^{\circ} 31^{\prime} 27^{\prime \prime} \mathrm{W}, 900-1000$ m, 8 mar. 1994 (fl., fr.), N. Roque et al. CFCR 14960 (ALCB, CTES, ESA, K-foto, SPF); Campo Formoso, Poços, 10²9'14"S, 40²7'41"W, 13 abr. 2006 (fl., fr.), R.D. Souza et al. 51 (HUEFS, SP); Castro Alves, fazenda Pinto, $12^{\circ} 45^{\prime} \mathrm{S}, 39^{\circ} 25^{\prime} \mathrm{W}, 27$ jan. 1957 (fl., fr.), R.P. Lordêlo 57-20 (ALCB); Conde, BA-233 entre Conde e Esplanada, $11^{\circ} 45^{\prime} 22^{\prime \prime S}, 37^{\circ} 46^{\prime} 10^{\prime W}, 129$ m, 23 jan. 2004 (fl.), R.M. Harley \& A.M. Giulietti 54714 (HUEFS); Coração de Maria, $10 \mathrm{~km} \mathrm{~W} \mathrm{da}$ cidade, estrada para Feira de Santana, $12^{\circ} 15^{\prime} \mathrm{S}, 38^{\circ} 50^{\prime} \mathrm{W}, 200 \mathrm{~m}, 2$ dez. 1992 (fl., fr.), M.M. Arbo et al. 5506 (CTES, HUEFS, SPF, UB); Dom Macedo Costa, fazenda Mocambo, $12^{\circ} 09^{\prime} \mathrm{S}, 39^{\circ} 19^{\prime} \mathrm{W}$, 25 jul. 1982 (fl.), M.J.S. Lemos 47 (ALCB, CEPEC, CTES, HRB, HUEFS); Entre Rios, fazenda experimental, Escola de Medicina Veterinária - UFBA, Reserva Florestal do Povoado de Aguazinha, $11^{\circ} 56$ 'S, 3805'W, 25 out. 2009 (fl., fr.), N. Roque et al. 2492 (ALCB); Esplanada, estrada para Sítio do Conde, $11^{\circ} 46^{\prime} 06^{\prime S}$, 3753'22"W, 8 maio 2000 (fl.), M.L. Guedes et al. 7358 (ALCB, CEPEC, HUEFS); Feira de Santana, campus da UEFS, $12^{\circ} 15^{\prime} \mathrm{S}$, 38 50'W, 18 maio 2006 (fl.), A.M. Lucchese 3 (HUEFS); Glória, Estação Ecológica do Raso da Catarina, 09¹9'59"S, 38²8'59"W, 26 jun. 1982 (fl.), L.P. Queiroz \& I. Crepaldi 379 (ALCB, HUEFS); Iaçu, Lage Preta, 1250'25"S, 3958'13"W, 400 m, 20 fev. 2005 (fl., fr.), F. França et al. 5134 (HUEFS, SP); Itaberaba, fazenda Itiberaba, inselbergue Morro Itibiraba, $12^{\circ} 29^{\prime} 58^{\prime \prime} \mathrm{S}, 40^{\circ} 04^{\prime} 56^{\prime \prime} \mathrm{W}, 19$ mar. 2006 (fl., fr.), E. Melo et al. 4312 (HST, HUEFS); Itatim, ápice da rocha exposta, 12²5'11"S, 3946'59"W, 25 jan. 1997 (fl., fr.), E. Melo et al. 1958 (HUEFS); Jacobina, Pouco d'Areia Jacobina, mar. 1845 (fl., fr.), J.S. Blanchet 3863 (lectótipo BR-foto, isolectótipos foto-BM, foto-G, foto-P); Juazeiro, Serra do Mulato, 0944'40"S, 4040'39"W, 27 mar. 2000 (fl., fr.), G. Cavalcanti et al.
64 (ALCB, CEPEC, HUEFS, SPF); Milagres, morro Pé de Serra, 1253'14"S, 39²49'53"W, 488 m, 25 out. 1997 (fl.), F. França et al. 2422 (CTES, HUEFS); Mucugê, a $13 \mathrm{~km}$ da cidade, $13^{\circ} 00^{\prime} \mathrm{S}$, 41 ${ }^{\circ} 37^{\prime} \mathrm{W}, 16$ dez. 1984 (fl., fr.), G.P. Lewis et al. CFCR 6999 (CTES, MBM, SPF); Palmeiras, estrada para Serra Preta, 12³1'55"S, 4135'14"W, 800 m, 28 mar. 2003 (fl.), E. Melo et al. 3610 (CTES, HUEFS); Paulo Afonso, Estação Ecológica do Raso da Catarina, Baixio da Onça, 09 $04^{\circ}$ 'S, 38 $8^{\circ} 22^{\prime} \mathrm{W}, 31$ mar. 2008 (fl., fr.), A. Melo et al. 286 (UFP); Quijingue, Serra das Candeias, ca. 5 $\mathrm{km}$ a W do Quixaba do Mandacaru, 1055'20"S, 3904'59"W, 573 m, 15 maio 2000 (fl., fr.), D. Cardoso \& T.M. Santana 553 (HUEFS); Rio de Contas, $8 \mathrm{~km}$ da cidade na estrada para Jussiape,

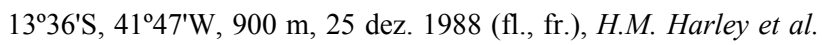
27724 (CEPEC, CTES, SPF); Santa Rita de Cássia, BA-135, antes $40 \mathrm{~km}$ de Formosa do Rio Preto, $2 \mathrm{~km}$ antes do povoado Entroncamento, $11^{\circ} 00^{\prime} 32^{\prime \prime S}, 44^{\circ} 31^{\prime} 08^{\prime \prime} \mathrm{W}, 5$ maio 2013 (est.), $L$. Rocha et al. 483 (HUEFS, CTES).

Pode ser reconhecida pelas estípulas bem desenvolvidas e persistentes, folhas e bractéolas obovadas, por vezes espatuladas, flores de corola branca, com base das pétalas amarela e frutos geralmente revestidos por restos florais. As sementes apresentam uma depressão puntiforme em cada aréola. A planta exala odor mentolado, em virtude dos tricomas glandulares. Turnera calyptrocarpa é similar a $T$. hebepetala, a qual se diferencia principalmente pelas folhas estreito-obovadas e pedúnculos florais geralmente mais curtos.

2.8. Turnera candida Arbo, Bonplandia 7: 68. 1993. Figuras 29; Arbo (2005: fig. 37G-J); Rocha \& Moreira (2014: fotos 35-37).

Ervas a subarbustos $30-70 \mathrm{~cm}$ alt.; caules estrigosos a denso-estrigosos, tricomas tectores simples, glandulares microcapitados e claviformes. Estípulas 2, rudimentares. Folhas com pecíolo 3-6 mm compr.; nectários 2, 1,3-1,9 mm diâm.; lâmina 0,9-7 × 0,5-2,6 cm, papirácea, ligeiramente discolor, elíptica, elíptico-oblonga a estreito-ovada, raro obovada, base cuneada, ápice agudo, margens planas, serrilhadas, dentes estreitos e regulares, 1/3 proximal inteiro; face adaxial estrigosa a esparso-estrigosa, nervuras impressas, face abaxial estrigosa, nervuras proeminentes. Inflorescências unifloras, solitárias ou agrupadas no ápice dos ramos; pedúnculo 2-4 $\mathrm{mm}$ compr., adnato ao pecíolo; brácteas ausentes; bractéolas 5-12 mm compr., linear-triangulares. Flores epífilas, homostilas; pedicelo ausente. Cálice 1,1-1,9 cm compr., externamente estrigoso. Corola 1,6-2,5 cm compr., branca, base das pétalas amarela às vezes com estrias azul escuras. Filetes 6-8 mm compr., glabros, margens 3-4 mm adnatas a unha das pétalas, formando sacos nectaríferos; anteras 2-3,3 mm compr., basifixas. Ovário ca. $2 \mathrm{~mm}$ compr., tomentoso-hirsuto; estiletes 5,5-8,5 mm compr., glabros; estigmas penicelados. Cápsulas 4,5-10 mm diâm.; epicarpo verrucoso, estrigoso. Sementes 2-3 $\times$ 0,7-1,2 mm, estreitoobovoides, retas, reticuladas; epiderme lisa; calaza obtusa, superfície plana. 
Ocorre na Bahia, Piauí e Minas Gerais (Arbo 2015). C7, D7, E6, E9, F5, F6, G4, G5, G6, I8, J8: campos rupestres, cerrados, caatingas e restingas. Habita afloramentos rochosos, encostas, principalmente em áreas abertas, por vezes perturbadas, como margens de rodovias e terrenos baldios. Cresce em substratos rochosos, argilosos e arenosos, em altitudes de 400 $1300 \mathrm{~m}$. Apresenta flores e frutos de agosto a maio.

Material selecionado - Abaíra, Catolés de Cima, 1316' $\mathrm{S}$, 41 ${ }^{\circ} 53^{\prime} \mathrm{W}, 1220$ m, 4 mar. 1992 (fl., fr.), B. Stannard et al. H51747 (CTES, SPF); Andaraí, estrada Mucugê-Andaraí, próximo ao entroncamento para Igatu, $12^{\circ} 51^{\prime} 17^{\prime \prime} \mathrm{S}, 41^{\circ} 18^{\prime} 44^{\prime \prime} \mathrm{W}, 347 \mathrm{~m}, 4$ maio 2009 (fl., fr.), L.P. Queiroz et al. 14594 (CTES, HUEFS); Brumado, subida para Rio de Contas, $14^{\circ} 12^{\prime} \mathrm{S}, 41^{\circ} 39^{\prime} \mathrm{W}, 6$ abr. 1992 (fl., fr.), G. Hatschbach et al. 56662 (holótipo CTES, isótipos K-foto, MBM); Caetité, Serra Geral, Brejinho das Ametistas, estrada para o Bloco III, $14^{\circ} 18^{\prime} 19^{\prime \prime} \mathrm{S}, 42^{\circ} 32^{\prime} 25^{\prime \prime} \mathrm{W}, 1023 \mathrm{~m}, 22$ maio 2008 (fl., fr.), M.L. Guedes \& F.S. Gomes 14513 (ALCB, CTES); Dias d'Ávila, estrada para São Sebastião do Passe, $12^{\circ} 36^{\prime} \mathrm{S}$, $38^{\circ} 17^{\prime} \mathrm{W}, 19$ nov. 2005 (fl., fr.), T.S. Nunes 1318 (HUEFS); Eunápolis, 16 $16^{\circ}$ 'S, 39³4'W, 8 fev. 2003 (fl., fr.), A.B. Xavier et al. 18 (ALCB); Igaporã, entre o trevo da BR-242 e Tanque Novo, 10 $15 \mathrm{~km} \mathrm{~N}, 1^{\circ} 46^{\prime} \mathrm{S}, 42^{\circ} 42^{\prime} \mathrm{W}, 21$ jan. 1997 (fl., fr.), G. Hatschbach et al. 66028 (CTES, MBM); Lençóis, Chapada Diamantina, 12³2'41"S, 41'23'35"W, 475 m, 12 mar. 2005 (fl., fr.), R. Funch et al. 724 (HUEFS); Licínio de Almeida, alto do Cachoeirão, 14²41'51"S, 42³3'21"W, 1112 m, 6 abr. 2013 (fl., fr.), L. Rocha et al. 402 (ALCB, HUEFS); Mucugê, estrada de Andaraí para

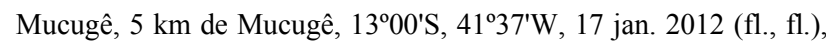
L. Rocha et al. 354 (CTES, HUEFS, RB); Mucuri, $6 \mathrm{~km}$ da rodovia Mucuri-Nova Viçosa, 1808'S, 3955'W, 10 m, 20 maio 1980 (fl., fr.), L.A. Mattos-Silva \& T.S. Santos 763 (CEPEC, CTES, HUEFS, MBM, UEC); Palmeiras, estrada para o Capão, $12^{\circ} 34^{\prime} 79^{\prime \prime S}$, 4130'76"W, 981 m, 29 abr. 2012 (fl., fl.), L. Rocha \& I. Souza 368 (CTES, HUEFS); Pindobaçu, Serra do Poço Pelado, topo da serra, $10^{\circ} 41^{\prime} 32 " \mathrm{~S}, 40^{\circ} 22^{\prime} 39^{\prime \prime} \mathrm{W}, 716$ m, 16 maio 2009 (fl., fr.), J.R. Maciel

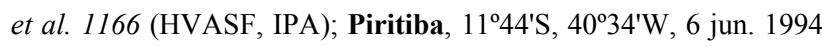
(fl., fr.), J.L.S. Lima 77 (HUEFS); Prado, 15-25 km da rodovia para Itamaraju, 17034'S, 39²2'W, 12 ago. 1995 (fl., fr.), G. Hatschbach et al. 63052 (CEPEC, CTES, MBM); Rio de Contas, $6,3 \mathrm{~km}$ da matriz da cidade, na estrada para Jussiape, $13^{\circ} 34^{\prime} \mathrm{S}, 41^{\circ} 48^{\prime} \mathrm{W}, 23 \mathrm{fev}$. 2004 (fl., fr.), H.M. Harley et al. 54968 (CTES, HUEFS); Tanque Novo, rodovia BR-430, 135''S, 42²4'W, 1000 m, 5 abr. 1992 (fl., fr.), G. Hatschbach et al. 56641 (CEPEC, CTES, MBM).

Pode ser reconhecida pelas folhas elípticas, elípticooblongas a estreito-ovadas, raro obovadas, com porção médio-apical serrilhada, com dentes estreitos e regulares e flores homostilas. É comum encontrar insetos em toda a planta, principalmente formigas nos nectários e besouros nas flores, que foram encontradas abertas até $16: 00$ hs. O pistilo de $T$. candida às vezes é até $2 \mathrm{~mm}$ maior que os estames, e a espécie pode ser confundida com a forma longistila de $T$. coerulea; mas nesta última, o gineceu é 4-6 $\mathrm{mm}$ maior que o androceu nas flores longistilas.

Turnera candida assemelha-se a $T$. coerulea e $T$. grandiflora (Urb.) Arbo. Turnera coerulea ocorre no sul dos Estados Unidos, México, Bolívia, e Centrooeste, Norte e Nordesde do Brasil, diferencia-se principalmente pelas folhas com margens serreadocrenadas, geralmente com dentes largos e irregulares e flores heterostilas; enquanto que $T$. grandiflora ocorre na Argentina, Paraguai, Bolívia e Centro-oeste do Brasil, diferencia-se principalmente pelas flores heterostilas e base das pétalas azul escura (Arbo 2005).

2.9. Turnera cearensis Urb., Jahrb. Königl. Bot. Gart. Berlin 2: 100. 1883.

Figuras 9E e 30; Arbo (2005: fig. 12A-J); Rocha \& Moreira (2014: fotos 38-40).

Subarbustos ou arbustos 0,5-3 m alt.; caules jovens tomentosos, tricomas estrelados e tectores simples. Estípulas 2, 1-3,5 mm compr. Folhas com pecíolo 4-9 mm compr.; nectários 1 ou 2 pares, ca. 0,5 mm diâm.; lâmina 2,4-11 × 0,9-5,5 cm, cartácea, discolor, ovada, largo-ovada, elíptica, raro obovada, base cuneada a cordada, ápice agudo a obtuso, margens duplamente crenadas a serreadas, planas ou revolutas; face adaxial pubescente, nervuras impressas, face abaxial tomentosa a velutina, nervuras proeminentes. Inflorescências unifloras, solitárias, às vezes agrupadas no ápice dos ramos; pedúnculo 1,5-10 mm compr., livre; folhas floríferas às vezes reduzidas a brácteas 6-10 × 5-9 mm, ovadas a largo-ovadas, nectários ausentes; bractéolas 7-10 $\mathrm{mm}$ compr., estreito-ovadas a linear-triangulares. Flores heterostilas; pedicelo ausente. Cálice 1-2 cm compr., externamente tomentoso-hirsuto. Corola 1,1-2,5 cm compr., amarela. Filetes 6-9 $\mathrm{mm}$ compr. em flores brevistilas, 3-6 $\mathrm{mm}$ compr. em flores longistilas, glabros a denso-pilosos, margens $2-5 \mathrm{~mm}$ adnatas à unha das pétalas, formando sacos nectaríferos; anteras 1,3-2 mm compr., dorsifixas. Ovário 3-5 mm compr., tomentoso; estiletes 2,5-3,5 $\mathrm{mm}$ compr. em flores brevistilas, 5-6,5 $\mathrm{mm}$ compr. em flores longistilas, pilosos; estigmas ramosos. Cápsulas $1-1,2 \mathrm{~cm}$ diâm.; epicarpo granuloso, hirsuto. Sementes 3,2-4 × 1,5-1,8 $\mathrm{mm}$, obovoides, ligeiramente curvas, estriadoreticuladas; epiderme papilosa; calaza proeminente, superfície côncava.

Distribui-se por todos os estados do Nordeste, até Minas Gerais (Arbo 2015). B9, C7, D3, D6, D7, D8, D9, E3/4, E6, E7, E8, E9, F6, G7: caatingas e cerrados. Habita áreas abertas, terrenos baldios, vegetações sujeitas a queimadas, além de margens de rodovias. Cresce em substratos arenosos e rochosos, em altitudes até $1200 \mathrm{~m}$. Apresenta flores e frutos durante o ano todo.

Material selecionado - Abaíra, Ouro Verde estrada para

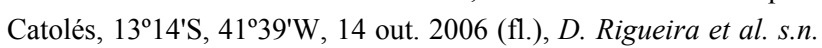
(ALCB 74679); Andaraí, próximo ao $\mathrm{Km} 286$ da BR-242, 12²7'56"S, 41 $00^{\circ} 07^{\circ} \mathrm{W}, 241$ m, 19 abr. 2009 (fl.), L.P. Queiroz \& D. Cardoso 13962 (HUEFS); Anguera, morro da fazenda Retiro, $12^{\circ} 10^{\prime} \mathrm{S}, 39^{\circ} 11^{\prime} \mathrm{W}, 380 \mathrm{~m}, 28$ nov. 2006 (fr.), D. Cardoso et al. 1444 (HUEFS); Antônio Gonçalves, 10³6'16"S, 40²16'14"W, 490 m, 12 abr. 2006 (fl.), E. Melo et al. 4396 (CTES, HUEFS); Campo Formoso, 10³0'32"S 40²5'59"W, 739 m, 13 abr. 2006 (fl.), R.F.S. Silva \& E. Melo 246 (CTES, HUEFS); Conceição do Coité, Serra 
do Mocambo, $11^{\circ} 30^{\prime}$ S, $39^{\circ} 11^{\prime} \mathrm{W}, 3$ fev. 2013 (fl., fr.), D.N. Carvalho \& A.O. Matos 181 (HUEFS); Contendas do Sincorá, Floresta Nacional de Contendas do Sincorá, $18,6 \mathrm{~km}$ a E de Tanhaçu, em linha reta, 1355'14"S, 41 $05^{\circ} 39^{\prime \prime} \mathrm{W}, 21$ fev. 2007 (fl.), R.M. Harley \& A.M. Giulietti 55601 (HUEFS); Feira de Santana, Estrada do Feijão, 12 ${ }^{\circ} 15^{\prime} \mathrm{S}, 38^{\circ} 50^{\prime} \mathrm{W}, 28$ abr. 2012 (fl.), L. Rocha \& I. Souza 366 (CTES, HUEFS, RB); Filadélfia, 6 km de Filadélfia na BA-385 para Itiúba, $10^{\circ} 45^{\prime} \mathrm{S}, 40^{\circ} 04^{\prime} \mathrm{W}, 400 \mathrm{~m}, 18$ fev. 1974 (fl., fr.), R.M. Harley et al. 16164 (CEPEC, CTES, RB); Iaçu, fazenda Suibra (Boa Sorte) $18 \mathrm{~km}$ a E da cidade, seguindo a ferrovia, $12^{\circ} 43^{\prime} \mathrm{S}$, 4007'W, 13 mar. 1985 (fl., fr.), L.R. Noblick 3611 (HUEFS); Ipirá estrada para a torre, $12^{\circ} 09^{\prime} \mathrm{S}, 38^{\circ} 40^{\prime} \mathrm{W}, 21$ out. 2011 (fl., fr.), M.L. Guedes et al. 19251 (ALCB); Irecê, $11^{\circ} 09^{\prime} \mathrm{S}, 41^{\circ} 56^{\prime} \mathrm{W}, 18$ jan. 1984 (fl., fr.), G. Fotius 3682a (EAC, IPA); Itaetê, antes 5-6 km da cidade, 12 ${ }^{\circ} 59^{\prime} 09^{\prime \prime S}, 40^{\circ} 58^{\prime} 22^{\prime \prime W}, 19$ jan. 2012 (fl., fl.), L. Rocha et al. 360 (HUEFS); Itiúba, $22 \mathrm{~km}$ a $\mathrm{W}$ da cidade, estrada para Filadélfia, 1043'S, 4003'W, 16 jan. 1997 (fl., fr.), M.M. Arbo et al. 7326 (CEPEC, CTES); Jaguarari, encosta da Crista, na fazenda Umburanas, 1006'10"S, 40¹3'46"W, 650 m, 13 abr. 2006 (fl.), R.F. Souza-Silva et al. 190 (CTES, HUEFS); João Correia, estrada Cascavel-João Correia, $13^{\circ} 17^{\prime} 55^{\prime \prime} \mathrm{S}, 4^{\circ} 27^{\prime} 30^{\prime \prime} \mathrm{W}, 1030 \mathrm{~m}, 17 \mathrm{dez}$. 2009 (fl.), M.L. Guedes et al. 16876 (ALCB, HUEFS); Jussara, Baixão dos Honoratos, $11^{\circ} 05^{\prime} \mathrm{S}, 41^{\circ} 49^{\prime} \mathrm{W}, 610$ m, 3 abr. 1984 (fl., fr.), H.P. Bautista \& A. Salgado-Odilon 925 (CEPEC, CTES, HUEFS, IPA, MBM, RB); Jussiape, estrada para Morro Branco, 13³1'S, 4136'W, 20 mar. 1999 (fl., fr.), R.M. Harley et al. 53553 (CEN, HUEFS); Lençóis, BR-242, 26 km a E da entrada para a cidade, 12 $29^{\prime} \mathrm{S}, 41^{\circ} 14^{\prime} \mathrm{W}, 20$ jan. 1997 (fl., fr.), M.M. Arbo et al. $7531 b$ (CEPEC, CTES, RB); Miguel Calmon, a $500 \mathrm{~m}$ da fazenda Serra Azul, 11'22'51"S, 40²9'49"W, 560 m, 14 dez. 2011 (fl.), E.S. Araújo \& R. Alencar 14 (CTES); Milagres, Morro da Bandeirinha, $12^{\circ} 52$ 'S, 39 $51^{\prime} \mathrm{W}, 5$ nov. 2010 (fl., fr.), J. Cordeiro et al. 3762 (MBM); Morro do Chapéu, rio Ventura, $11^{\circ} 33^{\prime} \mathrm{S}, 41^{\circ} 09^{\prime} \mathrm{W}, 17 \mathrm{dez}$. 2005 (est.), F. França 5402 (HUEFS); Mucugê, rodovia MucugêBarra da Estiva, entrada para Guiné $17 \mathrm{~km}$, ca. $0,8 \mathrm{~km}$ da entrada, $13^{\circ} 00^{\prime} \mathrm{S}, 41^{\circ} 37^{\prime} \mathrm{W}, 27$ jan. 2000 (fl., fr.), J.G. Jardim et al. 2555 (CEPEC, RB); Palmeiras, ca. 2,2 km da entrada para Palmeiras a partir da BR-242, 12 $27^{\prime} 50^{\prime \prime S}, 4^{\circ} 35^{\prime} 02^{\prime \prime W}, 700$ m, 29 jan. 2005 (fl.), J. Paula-Souza et al. 5051 (CTES, ESA); Paulo Afonso, borda da estrada que leva ao alojamento da Polícia Federal, 0904'S, $38^{\circ} 22^{\prime} \mathrm{W}, 31$ mar. 2008 (bot.), A. Alves-Araújo et al. 918 (UFP); Pindobaçu, Serra da Fumaça, trilha para a serra, 10³9'57"S, 40²1'14"W, 16 dez. 2008 (fl.), L.A. Sousa 209 (HUEFS); Poções, $14^{\circ} 52^{\prime} \mathrm{S}, 40^{\circ} 36^{\prime} \mathrm{W}, 13 \mathrm{~km}$ ao $\mathrm{S}$ de Poções, 30 jan. 1963 (fl.), $A$. Krapovickas 10097 (CTES, MBM); Rio de Contas, caminho para rio Água Suja, 132' 54 "S, 414ㄴ'41"W, 680 m, 12 fev. 2010 (fl., fr.), N. Roque et al. 2672 (ALCB, MBM); Rui Barbosa, ARIE Serra do Orobó, trilha Pátio das Orquídeas, $12^{\circ} 18^{\prime} 03^{\prime \prime} \mathrm{S}$, 40²9'15"W, 477 m, 20 abr. 2006 (fl.), D. Cardoso \& K.S. Matos 1220 (HUEFS); São Gabriel, fazenda Boa Sorte, $11^{\circ} 01^{\prime} \mathrm{S}, 41^{\circ} 39^{\prime} \mathrm{W}$, 798-800 m, 4 abr. 2009 (fl.), R.F. Machado et al. 158 (HUEFS); Santa Terezinha, Tanquinho, $12^{\circ} 50^{\prime} \mathrm{S}, 39^{\circ} 28^{\prime} \mathrm{W}, 25$ set. 1984 (fl.), L.R. Noblick \& M.J.S. Lemos 3413 (CEPEC, CTES, HUEFS, UEC); Santana, 12 $58^{\prime} 59^{\prime \prime S}, 44^{\circ} 03^{\prime} 03^{\prime \prime W}, 4$ jan. 1984 (fl., fr.), G. Fotius 3673 (IPA); Senhor do Bonfim, Serra de Santana, 10\%46'S, 40¹9'W, 700-900 m, 6 fev. 2003 (fl.), R. Rebouças et al. 1 (IBGE, MBM); Tucano, povoado Pedra Grande, estrada para a Serra de Pai Miguel, $11^{\circ} 07^{\prime} 22^{\prime \prime S}, 38^{\circ} 46^{\prime} 23^{\prime \prime} \mathrm{W}, 233$ m, 17 abr. 2008 (fl.), L.P. Queiroz et al. 13672 (HUEFS); Vitória da Conquista, BR-116, 3 $\mathrm{km}$ antes da cidade, $14^{\circ} 51^{\prime} \mathrm{S}, 40^{\circ} 50^{\prime} \mathrm{W}, 25$ abr. 2013 (fl.), L. Rocha \& P. Gomes 414 (CTES, HUEFS, IPA, MBM, RB, SPF).

Pode ser reconhecida pela presença de tricomas estrelados no indumento, inflorescências unifloras e corola amarela. Os ramos adultos podem ser castanhoavermelhados ou acinzentados, com abundantes lenticelas. As flores foram encontradas abertas até 17:00 hs, visitadas por borboletas, besouros, formigas pretas e vermelhas, além de algumas espécies de moscas e aranhas verdes. Turnera cearensis apresenta hábito e indumento e cor das pétalas similares aos de $T$. blanchetiana, que se diferencia pelas flores sésseis, bracteadas, reunidas em capítulos terminais.

2.10. Turnera chamaedrifolia Cambess. in SaintHilaire, Jussieu \& Cambessedes, Fl. Bras. Merid. 2: 221. 1830.

Figuras 9F, G e 30 Arbo (2000: fig. 20A-F); Rocha \& Moreira (2014: fotos 41 e 42).

Ervas a arbustos $0,2-1,6 \mathrm{~m}$ alt.; caules densopilosos a hirsutos, tricomas tectores simples e glandulares capitado-estipitados. Estípulas rudimentares. Folhas com pecíolo 2-10 mm compr.; nectários ausentes; lâmina $0,5-4,5 \times 0,5-2,3 \mathrm{~cm}$, papirácea, geralmente concolor, ovada, elíptica a obovada, base cuneada a atenuada, ápice agudo a obtuso, margens serreado-crenadas, planas a ligeiramente revolutas; face adaxial esparso-estrigosa a setosa, às vezes apenas com esparsos tricomas glandulares, nervuras impressas, face abaxial esparsopilosa, nervuras proeminentes. Inflorescências unifloras, solitárias; pedúnculo 8-15 mm compr., livre ou $1 \mathrm{~mm}$ adnato ao pecíolo; brácteas ausentes; bractéolas 5-13 mm compr., linear-triangulares. Flores heterostilas, raro homostilas; pedicelo ausente. Cálice 4-15 mm compr., externamente denso-piloso. Corola 5-15 mm compr., creme, base das pétalas vinácea. Filetes 4,7-5 mm compr. em flores brevistilas, 3-4 mm compr. em flores longistilas, glabros, base ca. $0,3 \mathrm{~mm}$ adnata ao tubo floral; anteras ca. 1,5 $\mathrm{mm}$ compr., dorsifixas. Ovário 1,5-2,5 $\mathrm{mm}$ diâm., tomentosohirsuto; estiletes 1,5-2,2 $\mathrm{mm}$ compr. em flores brevistilas, 3-4 $\mathrm{mm}$ compr. em flores longistilas, glabros; estigmas penicelados. Cápsulas 5-7 $\mathrm{mm}$ diâm.; epicarpo granuloso, hirsuto. Sementes 1,5-2 $\times$ 0,8-1 mm, obovoides, retas, reticuladas; epiderme lisa; calaza obtusa, superfície plana.

Distribui-se por todos os estados do Nordeste, até Minas Gerais e Rio de Janeiro (Arbo 2015). B9, C7, C8, D6, D7, D8, D9, E7, E8, E9, F6, F7, G8, H8: caatingas, cerrados, campos rupestres, florestas úmidas, restingas e dunas. Espécie ruderal, comumente encontrada em áreas abertas, terrenos baldios e locais perturbados, assim como em áreas urbanas e rodovias. Cresce em substratos arenosos, argilosos e rochosos, em altitudes até $1200 \mathrm{~m}$. Apresenta flores e frutos durante o ano todo.

Material selecionado - Alagoinhas, campus II UNEB, $12^{\circ} 10^{\prime} 68^{\prime \prime} \mathrm{S}, 38^{\circ} 24^{\prime} 81^{\prime \prime W}, 14$ nov. 2003 (fl., fr.), N.G. Jesus et al. 


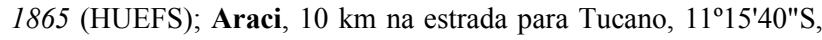
$38^{\circ} 35^{\prime} 00^{\prime \prime W}, 20$ fev. 2000 (fl., fr.), A.M. Giulietti \& R.M. Harley 1707 (CTES, HUEFS); Aramari, 1204'S, 38²9'W, 21 dez. 1922 (fl.), P. Campos-Porto 1343 (RB); Barra da Estiva, 10-15 km a W de Capão de Volta, estrada para Jussiape, $13^{\circ} 30^{\prime} \mathrm{S}, 41^{\circ} 30^{\prime} \mathrm{W}, 1100$ 1200 m, 20 jan. 1997 (fl.), M.M. Arbo et al. 7584 (CEPEC, CTES, FURB, UPCB); Brejões, $6 \mathrm{~km} \mathrm{~S}, 1^{\circ} 06^{\prime} \mathrm{S}, 39^{\circ} 47^{\prime} \mathrm{W}, 14$ set. 1984 (fl., fr.), G. Hatschbach 48184 (CEPEC, CTES, MBM); Brumado, ca. $13,4 \mathrm{~km}$ ao $\mathrm{S}$ de Livramento, $13^{\circ} 47^{\prime} 17^{\prime \prime} \mathrm{S}, 41^{\circ} 50^{\prime} 04^{\prime \prime} \mathrm{W}, 498 \mathrm{~m}$, 15 jun. 2002 (fl., fr.), L.P. Queiroz et al. 7057 (CTES, HUEFS); Buerarema, Olivença, Canabrava, $14^{\circ} 57^{\prime} \mathrm{S}, 39^{\circ} 18^{\prime} \mathrm{W}, 14$ jun. 2003 (fl., fr.), G. Hatschbach et al. 75539 (MBM); Cachoeira, Barragem de Bananeiras, vale dos rios Paraguaçu e Jacuípe, $12^{\circ} 32^{\prime} \mathrm{S}, 39^{\circ} 05^{\prime} \mathrm{W}$, 40-120 m, 2 maio 1980 (fl.), Grupo Pedra do Cavalo 19 (ALCB, CEPEC, HUEFS, RB); Camaçari, Região Metropolitana de Salvador, $12^{\circ} 41^{\prime} \mathrm{S}, 38^{\circ} 19^{\prime} \mathrm{W}, 12$ nov. 2005 (fl., fr.), J.S. Santos et al. 7 (ALCB, MBM); Campo Formoso, 10³0'32"S, 40²5'59"W, 739 m, 13 abr. 2006 (fl.), R.F.S Silva \& E. Melo 241 (CTES, HUEFS); Candeal, $8 \mathrm{~km}$ a $\mathrm{N}$ de Tanquinho, estrada para Ichu, $11^{\circ} 54^{\prime} \mathrm{S}$, 3906'W, 200-300 m, 15 jan. 1997 (fl.), M.M. Arbo et al. 7251 (CEPEC, CTES); Capim Grosso, $10 \mathrm{~km}$ ao $\mathrm{S}$ de Capim Grosso, estrada para Baixa Grande, 11 ${ }^{\circ} 27^{\prime} \mathrm{S}, 40^{\circ} 02^{\prime} \mathrm{W}, 150 \mathrm{~m}, 12$ abr. 1983 (fl., fr.), A. Krapovickas et al. 38805 (CEN, CTES, MBM); Castro Alves, Serra da Jibóia, 1251'11"S, 39²8'19"W, 680 m, 15 maio 1999 (fl., fr.), H.C. Oliveira \& S.J. Leite s.n. (CTES 392536, HUEFS 45323); Conceição de Feira, margem esquerda do rio Paraguaçu, 12³2'35"S, 3903'06"W, 17 fev. 1981 (fl., fr.), A.M. Carvalho et al. 538 (ALCB, CEPEC, CTES); Conceição do Coité, Serra do Mocambo, $11^{\circ} 30^{\prime} \mathrm{S}, 39^{\circ} 11^{\prime} \mathrm{W}, 3$ fev. 2013 (fl., fr.), D.N. Carvalho \& A.O. Matos 184 (HUEFS); Conceição do Jacuípe, $12^{\circ} 19^{\prime} \mathrm{S}, 38^{\circ} 45^{\prime} \mathrm{W}$, abr. 1974 (fl., fr.), G.C.P. Pinto 42300 (ALCB, CEPEC, CTES, IPA); Coração de Maria, $10 \mathrm{~km}$ a W da cidade, estrada para Feira de Santana, 12 $15^{\prime} \mathrm{S}, 38^{\circ} 50^{\prime} \mathrm{W}, 20$ m, 2 dez. 1992 (fl., fr.), M.M. Arbo et al. 5507 (CTES, HUEFS, SPF); Cravolândia, Três Braços, $13^{\circ} 21^{\prime} \mathrm{S}, 3^{\circ} 48^{\prime} \mathrm{W}, 15$ jan. 1991 (fl., fr.), E. Melo \& F. França 488 (UB); Cruz das Almas, 12\%40'11"S, 3906'06"W, 18 jan. 1980 (fl., fr.), G.C.P. Pinto 1068 (IPA, HUEFS, MBM); Dias d'Ávila, acesso a BR-093, $12^{\circ} 36^{\prime} \mathrm{S}, 38^{\circ} 17^{\prime} \mathrm{W}$, 5 ago. 1974 (fl., fr.), M.L. Guedes s.n. (ALCB 26854); Feira de Santana, Estrada do Feijão, lado esquerdo, $12^{\circ} 16^{\prime} \mathrm{S}, 38^{\circ} 58^{\prime} \mathrm{W}, 30$ abr. 2012 (fl.), L. Rocha \& I. Souza 376 (CTES, HUEFS); Filadélfia, estrada para Pindobaçu, a $14 \mathrm{~km}$ da BR-407, 10 $48^{\prime} \mathrm{S}$, 40¹4'W, 16 jan. 1997 (fl.), M.M. Arbo et al. 7332 (CEPEC, CTES, HRB); Glória, Serra do Salgado, 0908'31"S, 38 $200^{\prime} 11^{\prime \prime W}, 8$ set. 1987 (fl.), A.S. Conceição 1184 (HUEFS); Governador Mangabeira, BR-101, proximidades da represa Pedra do Cavalo, 12³5'S, 3901'W, 14 jan. 1997 (fl., fr.), M.M. Arbo et al. 7217 (ALCB, CEPEC, CTES, HRB, HUEFS, MBM); Iaçu, arredores da fazenda Suibra, $12^{\circ} 46^{\prime} \mathrm{S}, 40^{\circ} 12^{\prime} \mathrm{W}, 255 \mathrm{~m}, 6$ fev. 2005 (fl., fr.), $J$. Paula-Souza et al. 5520 (CTES, ESA); Ibirapitanga, 14 $16^{\prime} \mathrm{S}$, 39³7'W, 10 abr. 1992 (fl., fr.), G. Hatschbach et al. 56982 (CEPEC, CTES, MBM); Inhambupe, $11^{\circ} 47^{\prime} \mathrm{S}, 38^{\circ} 21^{\prime} \mathrm{W}, 14$ set. 1975 (fl., fr.), E.F. Gusmão 216 (ALCB); Ipecaetá, fazenda Riachão, Serra Orobozinho, 12¹9'59"S, 39²16'59"W, 14 ago. 1985 (fl., fr.), L.R. Noblick \& C.G. Lôbo 4353 (ALCB, HRB, HUEFS); Ipirá, fazenda Calderão, 12 $09^{\prime} \mathrm{S}, 39^{\circ} 44^{\prime} \mathrm{W}, 18$ jul. 1984 (fl., fr.), B.C. Bastos 502 (ALCB); Itaberaba, 12 $31^{\circ} 00^{\prime \prime} \mathrm{S}, 40^{\circ} 16^{\prime} 59^{\prime \prime} \mathrm{W}, 22$ abr. 1984 (fl.), L.R. Noblick et al. 3127 (CEPEC, HUEFS); Itaetê,

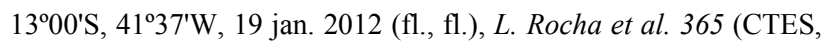

HUEFS, RB); Itanagra, Núcleo Agroecológico, 12²2'28"S, 3758'46"W, 68 m, 21 set. 2008 (fl., fr.), A.R. Prates 113 (ALCB); Itatim, Morro do Agenor ou da Madeira, $12^{\circ} 43^{\prime} 00^{\prime \prime S}, 39^{\circ} 42^{\prime} 00^{\prime \prime} \mathrm{W}$, 310-430 m, 17 dez. 1995 (fl., fr.), E. Melo et al. 1405 (CTES, HUEFS, R); Itiúba, estrada para Picos, 10³9'54"S, 3952'19"W, 396 m, 17 ago. 2002 (fl.), L.P. Queiroz et al. 7334 (HUEFS); Jacobina, $11^{\circ} 10^{\prime} \mathrm{S}, 40^{\circ} 31^{\prime} \mathrm{W}, 19$ abr. 2009 (fl., fr.), M.L. Guedes et al. 14782 (ALCB); Jaguarari, crista quartzítica, 1006'01"S, $40^{\circ} 13^{\prime} 45^{\prime \prime} \mathrm{W}, 580 \mathrm{~m}, 30$ jul. 2005 (fl.), D.S. Carneiro-Torres et al. 415 (HUEFS); Jequié, Km 7 da estrada Jequié-Ipiaú, 1351'S, $40^{\circ} 05^{\prime} \mathrm{W}, 10$ fev. 1983 (fl.), A.M. Carvalho \& T. Plowman 1586 (CEPEC, CTES); Lamarão, Ponto 5, área próximo a Caraíba Metais, $11^{\circ} 46^{\prime} \mathrm{S}, 38^{\circ} 54^{\prime} \mathrm{W}, 21$ abr. 2001 (fl.), M.L. Guedes et al. 8325 (ALCB, CEPEC); Maracás, BA-026, $17 \mathrm{~km}$ da cidade, $13^{\circ} 27^{\prime} \mathrm{S}, 40^{\circ} 23^{\prime} \mathrm{W}, 7$ abr. 2013 (fl., fr.), L. Rocha et al. 408 (ALCB,

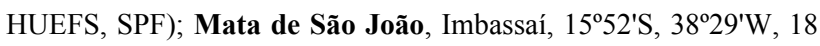
jun. 2003 (fl., fr.), G. Hatschbach et al. 75456 (CEPEC, CTES, MBM); Milagres, Morro de São Cristóvão, $12^{\circ} 52^{\prime} \mathrm{S}, 39^{\circ} 51^{\prime} \mathrm{W}, 5$ nov. 2010 (fl., fr.), J. Cordeiro et al. 3682 (MBM); Monte Santo, $10^{\circ} 27^{\prime} \mathrm{S}, 39^{\circ} 20^{\prime} \mathrm{W}, 610 \mathrm{~m}, 20$ fev. 1974 (fl., fr.), R.M. Harley 16402 (CTES, CEPEC, IPA, RB); Morro do Chapéu, Boca do Cedro, BA-052, para Utinga, $11^{\circ} 55^{\prime} \mathrm{S}, 41^{\circ} 15^{\prime} \mathrm{W}, 28$ jan. 2013 (fl.), L. Rocha \& B.S. Gregório 387 (HUEFS, RB); Mucugê, $31 \mathrm{~km} \mathrm{SW}$ da cidade, estrada para Barra da Estiva, $13^{\circ} 13^{\prime} \mathrm{S}, 4^{\circ} 28^{\prime} \mathrm{W}, 1100 \mathrm{~m}, 25$ nov. 1992 (fl., fr.), M.M. Arbo et al. 5761 (CTES, HUEFS, SPF, UB); Muritiba, 12³7'35"S, 3859'24"W, 27 maio 2003 (fl., fr.), I.M. Andrade et al. 789 (HUEFS); Paulo Afonso, 09 $04^{\circ} \mathrm{S}, 38^{\circ} 22^{\prime} \mathrm{W}$, 1954 (fl.), J. Vidal IV-794 (R); Pindobaçu, Serra da fumaça, 104'34"S, 40²1'46"W, 16 dez. 2008 (fl., fr.), L.A. Sousa 220 (HUEFS); Piritiba, $11^{\circ} 43^{\prime} \mathrm{S}, 40^{\circ} 33^{\prime} \mathrm{W}, 31$ maio 1980 (fl., fr.), L.R. Noblick 1854 (ALCB); Queimadas, Rio Jacurici, $7 \mathrm{~km}$ a $\mathrm{N}$ da estrada para Cansanção, 10 ${ }^{\circ} 55^{\prime} \mathrm{S}, 39^{\circ} 38^{\prime} \mathrm{W}, 16$ jan. 1997 (fl., fr.), M.M. Arbo et al. 7284 (CEPEC, CTES); Quijingue, Serra das Candeias, ca. $5 \mathrm{~km}$ a W do Quixaba do Mandacaru, 10 $55^{\circ} 20^{\prime \prime S}$, 3904'59"W, 400-630 m, 8 jul. 2006 (fl.), D. Cardoso \& T.M. Santana 1337 (HUEFS); Retirolândia, ca. $5 \mathrm{~km} \mathrm{~N} \mathrm{da} \mathrm{cidade,}$ $11^{\circ} 28^{\prime} 45^{\prime \prime S}, 39^{\circ} 26^{\prime} 32^{\prime \prime} \mathrm{W}, 250$ m, 1 nov. 1999 (fl., fr.), R.P. Oliveira et al. 295 (HUEFS, SP); Riachão do Jacuípe, 11\%47'56"S, $39^{\circ} 19^{\prime} 17^{\prime \prime W}, 275$ m, 7 jun. 2009 (fl., fr.), E. Melo et al. 6276 (HUEFS); Rio de Contas, estrada para Lagoa Nova, 134' $42^{\prime \prime}$, 41ㅇ' 44"W, 490 m, 5 fev. 1997 (fl., fr.), E. Saar et al. PCD 5100 (ALCB, CEPEC, CTES, HUEFS, SPF); Salvador, dunas do Abaeté, 12 56'40"S, 38²1'25"W, 29 m, 2 set. 2012 (fl., fr.), U.C.S. Silva et al. 167 (HUEFS); Santa Bárbara, Km 33 da BR-116, 11 ${ }^{\circ} 57^{\prime} \mathrm{S}$, $38^{\circ} 58^{\prime} \mathrm{W}, 30$ jan. 1980 (fl., fr.), L.R. Noblick 1646 (ALCB, CEPEC, CTES, IPA); Santa Luz, estrada para Queimadas, $11^{\circ} 11^{\prime} 44$ "S, 39²5'26"W, 18 abr. 2004 (est.), C.F. Nepomuceno et al. 2 (HUEFS); Santa Teresinha, 12 $51^{\prime} 13^{\prime \prime S}, 39^{\circ} 28^{\prime} 32 " \mathrm{~W}, 822 \mathrm{~m}, 25$ out. 2010 (fl., fr.), M.L. Guedes et al. 17837 (ALCB); São Gabriel, fazenda Boa Sorte, $11^{\circ} 02^{\prime} \mathrm{S}, 41^{\circ} 40^{\prime} \mathrm{W}, 798-800 \mathrm{~m}, 2$ abr. 2009 (fl.), R.F. Machado et al. 108 (HUEFS); São Sebastião do Passé, ponto 2, ao lado da Bacel, 12²51'S, 3849'W, 17 out. 1998 (fl., fr.), A.F.S. Nascimento et al. 88 (ALCB, CEPEC); Senhor do Bonfim, Monte Santo (Alto do Cruzeiro), 10³1'02"S, 40¹4'55"W, 903 m, 28 out. 2005 (fl., fr.), S.F. Conceição et al. 300 (HUEFS); Serra Preta, $12^{\circ} 10^{\prime} 00^{\prime \prime S}, 39^{\circ} 19^{\prime} 59^{\prime \prime W}, 17$ jul. 1985 (fl.), L.R. Noblick \& Lemos 4145 (HUEFS); Serrinha, povoado de Barra do Vento, próximo à

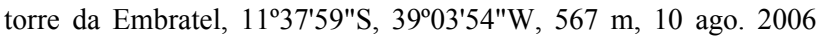
(fl.), D. Cardoso et al. 1376 (CTES, HUEFS); Tucano, Buraco do 


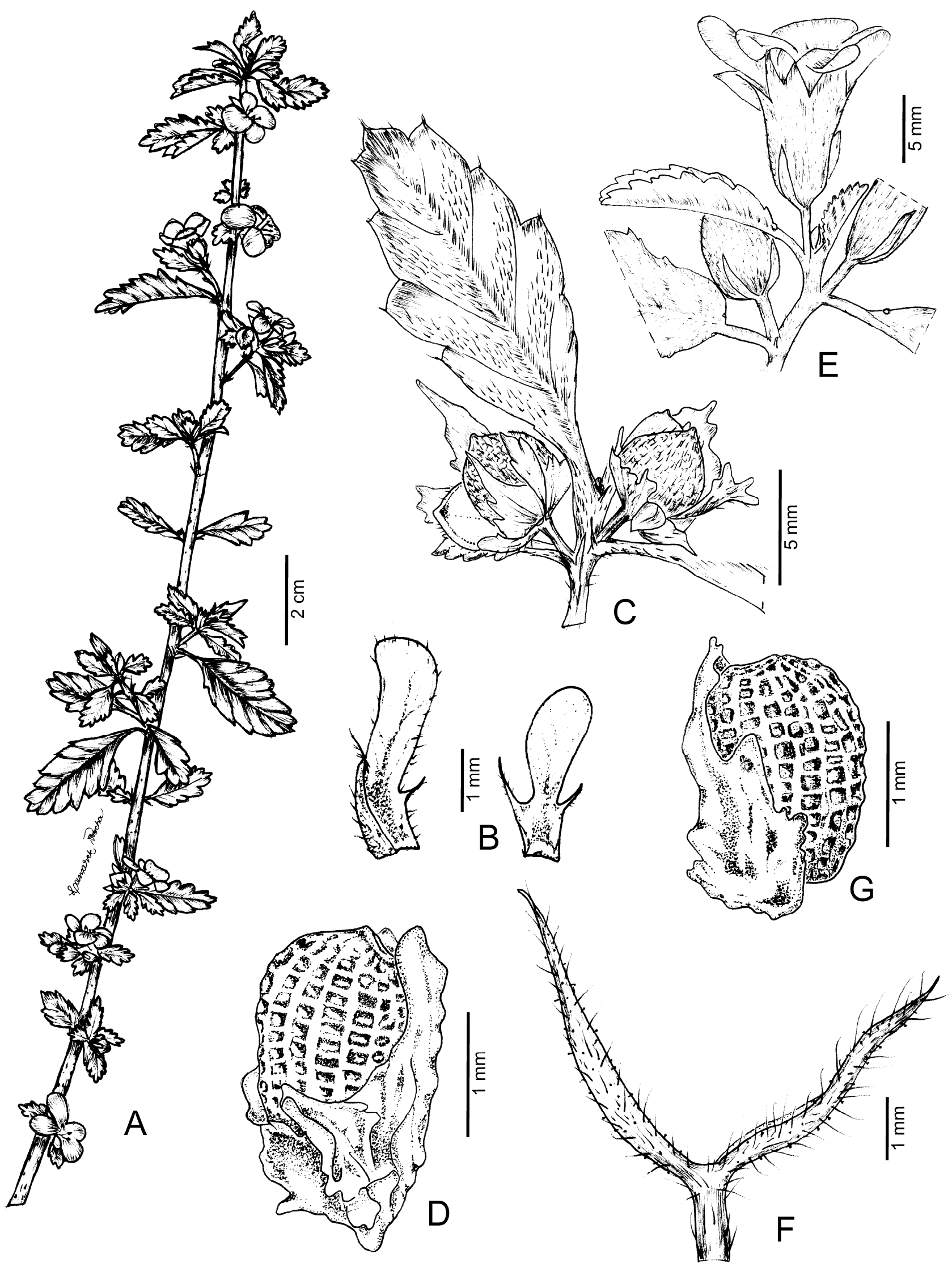

Figura 9. A-D. Turnera calyptrocarpa: A- ramo reprodutivo; B- bractéolas (face adaxial); C- porção do ramo evidenciando frutos revestidos por restos florais; D- semente (Popovkin 460). E. T. cearensis: porção do ramo reprodutivo, detalhe nos pedúnculos e bractéolas (Rocha 431). F, G. T. chamaedrifolia: F- bractéolas (face abaxial); G- semente (Rocha 365). 
Vento, 10 $0^{\circ} 57^{\prime} \mathrm{S}, 38^{\circ} 47^{\prime} \mathrm{W}, 9$ nov. 2010 (fl., fr.), J. Cordeiro et al. 3840 (MBM); Várzea Nova, BA-426, 7 km a SW de Várzea Nova, estrada para Morro do Chapéu, $11^{\circ} 18^{\prime} \mathrm{S}, 40^{\circ} 58^{\prime} \mathrm{W}, 700-800 \mathrm{~m}, 17$ jan. 1997 (fl.), M.M. Arbo et al. 7427 (CEPEC, CTES).

Pode ser reconhecida pelos pedúnculos bem desenvolvidos e corola creme com base das pétalas vinácea ou rósea quando seca. Apresenta uma grande variação no hábito e tamanho das folhas, podendo ser encontradas ervas a subarbustos, prostrados ou eretos, geralmente com folhas pequenas, às vezes grandes, até ca. 4,5 cm compr. Devido aos tricomas glandulares capitado-estipitados, exala odor mentolado. Os espécimes podem adquirir uma coloração castanho-avermelhada quando secos. As flores foram encontradas abertas até 16:00 hs, visitadas por besouros, formigas e borboletas. Turnera chamaedrifolia se assemelha a $T$. caatingana e $T$. asymmetrica; esta primeira é restrita à região sudoeste da Bahia e diferencia-se pelos ramos com ápice densamente hirsuto e folhas e flores geralmente maiores; a segunda se diferencia principalmente pelas bractéolas ovadas e assimétricas, além das pétalas amarelas. O exemplar Rocha 376 apresenta flores quase homostilas, algo raro nesta espécie (Arbo 2000).

2.11. Turnera chrysocephala Urb., Repert. Spec. Nov. Regni Veg. 4: 134. 1907. Figura Arbo (2005: fig. 7A-J).

Arbustos 0,5-2 $\mathrm{m}$ alt.; caules tomentosos a glabrescentes, tricomas tectores simples. Estípulas 2, 5-8 mm compr. Folhas com pecíolo 7-15 mm compr.; nectários 1 ou 2(3) pares, 0,6-0,8 mm diâm.; lâmina 4,3-9 × 2,7-5,5 cm, cartácea, discolor, ovada ou estreito-ovada, base arredondada a cuneada, ápice obtuso, raro agudo, margens duplamente crenadas, ligeiramente revolutas; face adaxial pubescente, nervuras impressas, face abaxial tomentosa nervuras proeminentes. Inflorescências em capítulos terminais; pedúnculo ausente; brácteas largo-ovadas, 2-4 pares de nectários, 0,2-0,5 mm diâm.; bractéolas 7-10 $\mathrm{mm}$ compr., obovadas a oblongas, ápice laciniado. Flores heterostilas; pedicelo ausente. Cálice 1,5-1,8 cm compr., externamente denso-estrigoso, tricomas dourados. Corola 1,6-1,9 cm compr., amarela. Filetes 8-9 mm compr. em flores brevistilas, ca. $7 \mathrm{~mm}$ compr. em flores longistilas, ápice piloso, margens ca. $5 \mathrm{~mm}$ adnatas ao tubo floral, formando sacos nectaríferos; anteras ca. $2 \mathrm{~mm}$ compr., dorsifixas. Ovário ca. 2,5 $\mathrm{mm}$ compr., hirsuto; estiletes ca. $4 \mathrm{~mm}$ compr. em flores brevistilas, ca. 5,5 $\mathrm{mm}$ compr. em flores longistilas, base hirsuta; estigmas multilobulados. Cápsulas ca. 6 mm diâm.; epicarpo liso, hirsuto. Sementes ca. $4 \times 1,7$ mm, obovoides, curvas, estriado-reticuladas; epiderme com papilas filiformes; calaza proeminente, superfície côncava.

Ocorre no Piauí e Bahia (Arbo 2015). O material proveniente da Bahia é referido para a Serra Geral do Goiás, trata-se da região oeste do estado da Bahia, na divisa com Goiás, mas não é possível especificar qual município.

Material examinado - Bahia-Goiás: "Serra Geral do Goyaz", 1914 (fl.), P. von Luetzelburg 397 (M-foto, NY-foto).

Material adicional examinado - BRASIL. Piauí: Canto do Buriti, entre Canto do Buriti e Itaueiras, 19 nov. 1979 (fl., fr.), $E$. Nunes \& P. Martins s.n. (CTES 53648).

Pode ser reconhecida pelo indumento composto apenas por tricomas simples, inflorescências em capítulos, portando flores com brácteas largo-ovadas e bractéolas obovadas a oblongas, além do cálice com tricomas densos e dourados. Assemelha-se a $T$. blanchetiana, a qual se diferencia principalmente pelo indumendo com tricomas estrelados.

\subsection{Turnera coccinea Arbo, Bol. Bot. Univ. São} Paulo 24: 126. 2006.

Figuras 31; Arbo (2008: fig. 11A-N); Rocha \& Moreira (2014: fotos 44 e 45).

Arbustos 0,5-1 m alt.; caules esparso a densoestrigosos, tricomas tectores simples. Estípulas rudimentares. Folhas com pecíolo 2-4 mm compr.; nectários 2, 0,3-1 $\mathrm{mm}$ diâm., maiores nas folhas floríferas; lâmina 10-20 × 5-12 $\mathrm{mm}$, cartácea, discolor, elíptica a elíptico-obovada, base atenuada, ápice agudo a obtuso, margens serreado-crenadas, revolutas; face adaxial estrigosa, nervuras impressas, face abaxial tomentoso-velutina, nervuras proeminentes. Inflorescências unifloras, reunidas em racemos terminais, raro flores solitárias; pedúnculo 1-2 $\mathrm{mm}$ compr., adnato ao pecíolo; brácteas ausentes; bractéolas 2,5-5 $\mathrm{mm}$ compr., linear-triangulares. Flores heterostilas, epífilas; pedicelo ausente. Cálice 8-10 mm compr., externamente denso a esparsoestrigoso. Corola 1-1,3 cm compr., vermelha, base das pétalas amarela. Filetes 7-9 $\mathrm{mm}$ compr. em flores brevistilas, ca. $5 \mathrm{~mm}$ compr. em flores longistilas, glabros, base 1-1,3 mm adnata ao tubo floral; anteras ca. $1 \mathrm{~mm}$ compr., dorsifixas. Ovário 1,5-2 mm compr., tomentoso; estiletes 4-5 $\mathrm{mm}$ compr. em flores brevistilas, ca. $8 \mathrm{~mm}$ em flores longistilas, ápice densopiloso; estigmas penicelados. Cápsulas 5-7 mm diâm.; epicarpo liso, esparso-estrigoso. Sementes 2,5-3 $\times$ ca. $1 \mathrm{~mm}$, obovoides, ligeiramente curvas, tenuamente reticuladas; epiderme papilosa; calaza pouco proeminente, superfície côncava.

Rara, era considerada endêmica de Grão-Mogol, em Minas Gerais (Arbo \& Giulietti 2009; Arbo 2015), sendo registrada pela primeira vez na Bahia neste estudo. G5: campos rupestres. Habita áreas abertas, com substrato arenoso, por vezes, entre rochas, em altitudes de 1112-1148 m. Apresenta flores e frutos nos meses de abril e maio.

Material examinado - Licínio de Almeida, Serra do Salto, estrada para a fazenda Riacho de Areira, 14\% $45^{\prime} 29^{\prime \prime} \mathrm{S}, 42^{\circ} 34^{\prime} 32^{\prime \prime} \mathrm{W}$, 1112 m, 12 maio 2012 (fl., fr.), N. Roque et al. 3565 (ALCB); ib., pico da Serra do Salto, 1445'28"S, 42³4'37"W, 1148 m, 5 abr. 2013 (fl., fr.), L. Rocha et al. 397 (ALCB, CTES, HUEFS, RB, SPF). 
Material adicional examinado - BRASIL. MINAS GERAIS: Grão Mogol, BR-251, extremo N da Serra da Bocaina, próximo das nascentes do rio Ventania, aprox. $16^{\circ} 15^{\prime} \mathrm{S}, 42^{\circ} 53^{\prime} \mathrm{W}, 920 \mathrm{~m}, 20$ nov. 1992 (fl., fr.), R. Mello-Silva et al. 760 (holótipo SPF, isótipos CTES, MBM, NY-foto).

Pode ser reconhecida principalmente pelas flores de corola vermelha e base das pétalas amarela, folhas cartáceas, elípticas a elíptico-obovadas, geralmente pequenas. Suas flores foram encontradas abertas nas primeiras horas da tarde, às 14:00 hs, visitadas por besouros e formigas. Turnera coccinea é similar a $T$. opifera e $T$. longiflora; a primeira se diferencia pelas flores amarelas e maiores; enquanto a segunda, que não ocorre na Bahia, difencia-se pelas folhas e flores geralmente maiores, com indumento denso, tomentoso-hirsuto a velutino.

\subsection{Turnera coerulea DC., Prodr. 3: 346. 1828.}

Figuras 31; Arbo (2005: figs 40A-F e 40G-M).

Ervas ou subarbustos 40-60 cm alt.; caules estrigosos a denso-estrigosos, tricomas tectores simples, glandulares microcapitados e claviformes. Estípulas rudimentares. Folhas com pecíolo 2-7 $\mathrm{mm}$ compr.; nectários 2, 0,7-1,3 mm diâm.; lâmina 0,9$5,0 \times 0,6-1,6(-2,5) \mathrm{cm}$, papirácea, concolor, ovada, estreito-ovada, elíptico-ovada, raro linear, base cuneada, ápice agudo a obtuso, margens planas, serreado-crenadas, dentes geralmente largos e irregulares; face adaxial estrigosa a esparso-pilosa, nervuras impressas, face abaxial estrigosa, nervuras proeminentes. Inflorescências unifloras, solitárias ou agrupadas no ápice dos ramos; pedúnculo 5-7 $\mathrm{mm}$ compr., totalmente adnato ao pecíolo; brácteas ausentes; bractéolas 5-7 $\mathrm{mm}$ compr., lineartriangulares. Flores heterostilas, epífilas; pedicelo ausente. Cálice 9-21 $\mathrm{mm}$ compr., externamente estrigoso. Corola 1,8-2,7(-3,1) cm compr., branca, por vezes com nervuras azul-escuras, base das pétalas amarela. Filetes 9-16 $\mathrm{mm}$ compr. em flores brevistilas, 6-6,5 $\mathrm{mm}$ compr. em flores longistilas, glabros, margens ca. 4,5 $\mathrm{mm}$ adnatas à unha das pétalas, formando sacos nectaríferos; anteras 2-2,5 mm compr., basifixas. Ovário 1,5-2,5 mm compr., tomentoso; estiletes 4-8 $\mathrm{mm}$ compr. em flores brevistilas, 10-11 mm compr. em flores longistilas, glabros; estigmas penicelados. Cápsulas 5-7 $\mathrm{mm}$ diâm.; epicarpo verrucoso, estrigoso. Sementes 2$2,5(-3,6) \times 1(-1,6) \mathrm{mm}$, obovoides, ligeiramente curvas, reticuladas; epiderme lisa; calaza obtusa, superfície plana.

Ocorre no México, Bolívia e Brasil, mas também há um antigo exemplar proveniente dos Estados Unidos (Arbo 2005). No Brasil, ocorre no Sudeste (Minas Gerais), Centro-oeste (Goiás, Mato Grosso do Sul e Mato Grosso), Nordeste (Bahia, Ceará, Maranhão, Pernambuco, Piauí e Sergipe) e Norte (Amazonas, Amapá, Pará, Roraima e Tocantins) (Arbo 2015). C8, D2, D10, E3: cerrados, caatingas, restingas e matas ciliares. Habita margens de rios e áreas perturbadas, como margens de trilhas e rodovias. Apresenta flores e frutos de janeiro a agosto.

Material selecionado - Correntina, drenagem do rio Corrente, próximo ao rio Piau, ca. $150 \mathrm{~km}$ a $\mathrm{SW}$ de Barreiras, $12^{\circ} 09^{\prime} \mathrm{S}$, 445'' W, 850 m, 14 abr. 1966 (fl., fr.), H.S. Irwin et al. 14797 (UB); Formosa do Rio Preto, Arroz de Baixo, ca. $11 \mathrm{~km}$ da cidade, fazenda do Sr. Júlio, $11^{\circ} 03^{\prime} 37^{\prime \prime S}, 45^{\circ} 16^{\prime} 19^{\prime \prime W}, 531 \mathrm{~m}, 4$ abr. 2000 (fl., fr.), R.P. Oliveira et al. 501 (ALCB, CEPEC, CTES, HUEFS); Itiúba, "Serra de Tiuba" (provavelmente Serra de Itiúba), aprox. $10^{\circ} 41^{\prime} \mathrm{S}, 39^{\circ} 51^{\prime} \mathrm{W}$, mar. (fl., fr.), C.F.P. Martius s.n. (M 0210494foto); Jandaíra, rodovia Linha Verde, $10-20 \mathrm{~km} \mathrm{~S}$ de Abadia, $11^{\circ} 33^{\prime} \mathrm{S}, 37^{\circ} 47^{\prime} \mathrm{W}, 19$ ago. 1995 (fl., fr.), G. Hatschbach et al. 63156 (CEPEC, CTES, MBM).

Turnera coerulea pode ser reconhecida pelas flores heterostilas, de corola branca e base das pétalas amarela, além de folhas serreado-crenadas, geralmente com dentes largos e irregulares. Assemelha-se a $T$. candida, a qual se diferencia pelas folhas elípticas regularmente serreadas e flores homostilas, com o gineceu até $2 \mathrm{~mm}$ maior que o androceu.

Arbo (2005) considerou duas variedades para esta espécie: T. coerulea var. coerulea e $T$. coerulea var. surinamensis (Urb.) Arbo \& A. Fernández; ambas ocorrem na Bahia. A variedade típica pode ser reconhecida pelas folhas ovadas ou elíptico-ovadas, com margens serreado-crenadas e face adaxial estrigosa; enquanto que $T$. coerulea var. surinamensis se diferencia pelas folhas lineares a estreito-ovadas com margens serrilhadas e face adaxial esparso-pilosa. Turnera coerulea var. coerulea integra o grupo de espécies com flores branco-azuladas, havendo híbridos com $T$. coerulea var. surinamensis, T. grandiflora, $T$. grandidentata (Urb.) Arbo e T. aurelii Arbo (Arbo \& Fernández 1987; Fernández 1987; Fernández \& Arbo 1990, 1996). Os exemplares Irwin 14797, Krapovickas 30178 e 30182 apresentam pétalas com base das pétalas azul e sementes grandes (3,3-3,6 × ca. 1,6 mm) e arilo com células papilosas, algo incomum nesta espécie.

\subsection{Turnera cuneiformis Juss. ex Poir., Encycl. 8:} 142. 1808.

Figuras 32; Arbo (2005: fig. 43A-E); Rocha \& Moreira (2014: fotos 46 e 47).

Subarbustos ou arbustos 0,5-1 m alt.; caules estrigosos a denso-estrigosos, tricomas tectores simples. Estípulas 2, rudimentares. Folhas com pecíolo 3-10 mm compr.; nectários 2, 1-1,5 diâm.; lâmina 1,0$4,5 \times 0,8-2,0 \mathrm{~cm}$, papirácea, ligeiramente discolor, ovada, elíptica ou obovada, base atenuada ou cuneada, ápice agudo, margens duplamente serreado-crenadas, planas; face adaxial esparso-estrigosa, nervuras impressas, face abaxial estrigosa ou vilosa, nervuras proeminentes. Inflorescências unifloras, solitárias a reunidas no ápice dos ramos; pedúnculo 5-7 $\mathrm{mm}$ compr., totalmente adnato ao pecíolo; brácteas ausentes; bractéolas 7-10 mm compr., lineartriangulares. Flores homostilas, epífilas; pedicelo ausente. Cálice 9-12 mm compr., externamente viloso. 
Corola 2-2,5 cm compr., amarela, raro creme, base das pétalas castanho-escura. Filetes 9-10 $\mathrm{mm}$ compr., glabros, margens ca. $2 \mathrm{~mm}$ adnatas a unha das pétalas, formando sacos nectaríferos; anteras 3-3,5 mm compr., basifixas. Ovário ca. $2 \mathrm{~mm}$ compr., hirsuto; estiletes ca. $1,1 \mathrm{~cm}$ compr., glabros; estigmas penicelados. Cápsulas 8-12 mm diâm.; epicarpo verrucoso, hirsuto. Sementes 2-3 $\quad$ \% 0,7-1 mm, estreito-obovoides, ligeiramente curvas, reticuladas; epiderme lisa; calaza obtusa, superfície plana.

Ocorre na Bahia, Distrito Federal, Espírito Santo, Goiás, Minas Gerais e Rio de Janeiro (Arbo 2015). D7, E6, G4, H6, I8: caatingas e matas úmidas. Espécie ruderal, habita áreas abertas, por vezes perturbadas, como margens de trilhas, rodovias ou zonas urbanas. Cresce em substratos argilosos ou argilo-rochosos, em altitudes até $955 \mathrm{~m}$. Apresenta flores e frutos nos meses de abril, maio, agosto e novembro.

Material selecionado - Anagé, $30 \mathrm{~km}$ de Vitória da Conquista, sentido Anagé, 14 $36^{\circ} \mathrm{S}, 41^{\circ} 08^{\prime} \mathrm{W}, 26$ abr. 2013 (fl., fr.), L. Rocha \& P. Gomes 418 (CTES, HUEFS, RB); Belmonte, Estação Experimental Gregório Bondar, CEPLAC, Barrolandia, 155' $\mathrm{S}, 38^{\circ} 52^{\prime} \mathrm{W}, 12$ ago. 1981 (fl., fr.), H.S. Brito \& S.G. Vinha 83 (CEPEC, CTES); Igaporã,

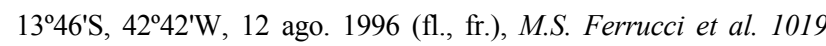
(ALCB, CEPEC, CTES, HUEFS, MBM); Jacobina, $11^{\circ} 13^{\prime} \mathrm{S}$, 40³0'W, 463 m, 30 nov. 1992 (fl., fr.), M.M. Arbo et al. 5449 (CTES, HUEFS, SPF, UB); Lençóis, BR-242, 14 km a E do acesso a Lençóis, $12^{\circ} 28^{\prime} \mathrm{S}, 41^{\circ} 25^{\prime} \mathrm{W}, 13$ abr. 1983 (fl., fr.), A. Krapovickas et al. 38816 (CEN, CTES, MBM); Palmeiras, estrada para o Capão,

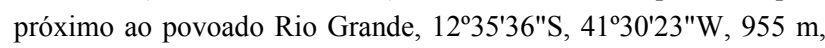
29 abr. 2012 (fl., fl.), L. Rocha \& I. Souza 373 (CTES, HUEFS); Porto Seguro, BR-367, a 16,5 km W de Porto Seguro, 16 ${ }^{\circ} 45^{\prime} \mathrm{S}$, 3906'W, 13 maio 1980 (fl., fr.), A. Eupunino 517 (CEPEC).

Pode ser reconhecida pelas flores homostilas, de corola amarela, raro creme e base das pétalas castanhoescura. Suas flores foram encontradas abertas até 15:00 hs. É comum encontrar besouros e formigas nos nectários florais e extraflorais. Turnera cuneiformis é similar a $T$. subulata e $T$. orientalis; a primeira se diferencia principalmente pelas flores heterostilas; a segunda, embora apresente flores homostilas, diferencia-se pela corola amarela. Quando secos, os espécimes são dificilmente distinguidos, principalmente quando não há informações sobre a coloração da corola, baseando-se principalmente na homostilia. Trata-se de uma espécie homostila, mas o gineceu pode ser até $1 \mathrm{~mm}$ maior que o androceu.

2.15. Turnera diffusa Willd. ex Schult., Syst. Veg. 6: 679. 1820.

Figuras 32; Arbo (2000: fig. 17A-F); Rocha \& Moreira (2014: fotos 48 e 49).

Arbustos 0,4-2 m alt.; caules esparso-pilosos a lanoso-tomentosos, tricomas tectores simples e glandulares capitado-sésseis. Estípulas 2, 0,5-2 $\mathrm{mm}$ compr. Folhas frequentemente dispostas em braquiblastos axilares ou terminais; pecíolo até $3 \mathrm{~mm}$ compr.; nectários ausentes; lâmina 5-25 × 3-15 mm, cartácea, discolor, ovada, elíptica a obovada, base cuneada ou atenuada, ápice obtuso, raro agudo, margens serreado-crenadas, revolutas; face adaxial glabra a esparso-pilosa, nervuras fortemente impressas, face abaxial vilosa a lanoso-tomentosa, nervuras proeminentes. Inflorescências unifloras, solitárias; pedúnculo 0,5-2 $\mathrm{mm}$ compr., 0,2-1 adnato ao pecíolo; brácteas ausentes; bractéolas 3-5 mm compr., lineartriangulares. Flores heterostilas, epífilas; pedicelo ausente. Cálice 3,5-6 mm compr., base esparso-hirsuta, lacínios vilosos a tomentosos. Corola 5-7 $\mathrm{mm}$ compr., amarela. Filetes 4,5-5 $\mathrm{mm}$ compr. em flores brevistilas, 3-3,5 $\mathrm{mm}$ compr. em flores longistilas, glabros a esparso-pilosos, base ca. 0,2 mm adnata ao tubo floral; anteras $0,7-1 \mathrm{~mm}$ compr., dorsifixas. Ovário 1-2 mm compr., tomentoso-hirsuto; estiletes 22,3 $\mathrm{mm}$ compr. em flores brevistilas, 3-5 mm compr. em flores longistilas, glabros a esparso-pilosos; estigmas penicelados. Cápsulas 2-3 $\mathrm{mm}$ diâm.; epicarpo verrucoso, hirsuto. Sementes $2-2,3 \times$ ca. 1 $\mathrm{mm}$, obovoides, curvas, reticuladas; epiderme lisa; calaza obtusa, superfície plana.

Ocorre no sul dos Estados Unidos (Texas), México, Antilhas e América do Sul (Arbo 2000). No Brasil, é registrada na maioria dos estados nordestinos (exceto Maranhão), até Minas Gerais (Arbo 2015). B6, B7, B9, C5, C6, C7, D5, D6, D7, D9, E6, E8, E9, F4, F5, F6, G5: caatingas, cerrados e campos rupestres. É comum em áreas abertas, por vezes perturbadas, como terrenos baldios, margens de rodovias e pastos. Cresce em substratos arenosos, areno-rochosos e argilosos, às vezes entre rochas, em altitudes até ca. $1300 \mathrm{~m}$. Apresenta flores e frutos o ano todo.

Material selecionado - Abaíra, estrada para Barra da Estiva, $13^{\circ} 15^{\prime} 51^{\prime \prime S}, 41^{\circ} 26^{\prime} 37^{\prime} \mathrm{W}, 10$ out. 2009 (fl., fr.), M.L. Guedes et al. 16662 (ALCB); Água Fria, estrada Irará/Água Fria, 11\%48'36"S, $38^{\circ} 37^{\prime} 21^{\prime \prime W}, 100-150$ m, 3 set. 2006 (fl., fr.), A.M. Amorim et al. 6199 (HUEFS, SPF); Alagoinhas, 1205'39"S, 38²2'01"W, 205 m, 23 abr. 2010 (fl.), E. Melo et al. 7951 (HUEFS); Aporá, 31 km ao S de Olindina, ao longo da BR-116, $11^{\circ} 39^{\prime} \mathrm{S}, 38^{\circ} 04^{\prime} \mathrm{W}, 310 \mathrm{~m}, 1 \mathrm{abr}$. 1976 (fl., fr.), G. Davidse et al. 11745 (CTES, MO-foto); Barra da Estiva, $10-15 \mathrm{~km}$ a W de Capão de Volta, estrada para Jussiape,

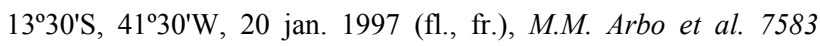
(CEPEC, CTES, HUEFS); Barra do Mendes, estrada para

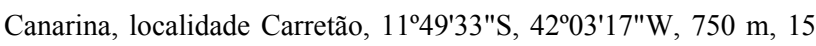
dez. 2009 (fl., fr.), E. Melo et al. 7503 (ALCB, HUEFS); Barra,

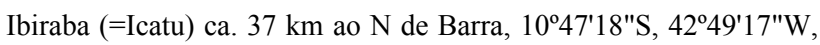
430 m, 19 maio 2010 (fl., fr.), L.P. Queiroz et al. 14672 (CEN, HUEFS); Caetité, Serra Geral, Brejinho das Ametistas, Bloco III, $14^{\circ} 21^{\prime} 49^{\prime \prime S}, 42^{\circ} 32^{\prime} 13^{\prime \prime W}, 988$ m, 22 maio 2008 (fl., fr.), M.L. Guedes et al. 14514 (ALCB, CTES); Cafarnaum, próximo à Várzea do Cerco, $12^{\circ} 00^{\prime} \mathrm{S}, 41^{\circ} 32^{\prime} \mathrm{W}, 800$ m, 16 mar. 1984 (fl., fr.), A. Salgado-Odilon 373 (CEPEC, HRB, MBM, RB); Campo Formoso, Serra dos Morgados, $10^{\circ} 14^{\prime} 34^{\prime \prime S}, 40^{\circ} 15^{\prime} 57^{\prime \prime} \mathrm{W}, 819 \mathrm{~m}, 14$ abr. 2006 (fl., fr.), V.J. Santos 582 (CTES, HUEFS); Canudos, Estação Biológica de Canudos, área da Toca Velha, 0956'S, $38^{\circ} 58^{\prime} \mathrm{W}, 18$ abr. 2004 (fl., fr.), F.H.M. Silva \& L.C.L. Lima 502 (HUEFS); Casa Nova, Dunas interiores do São Francisco, 09 $25^{\prime} 02^{\prime \prime S}, 41^{\circ} 08^{\prime} 56^{\prime \prime} \mathrm{W}, 419$ m, 30 nov. 2003 (fl., fr.), L.P. Queiroz

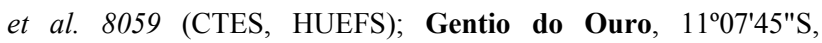


4244'20"W, 410 m, 26 jun. 2005 (fl., fr.), D.S. Carneiro-Torres et al. 544 (CTES, HUEFS); Glória, Serrota, 09²0'S, 38²9'W, 26 abr. 2006 (fl.), M. Colaço \& C.O. Nunes 122 (CTES, HUEFS); Ibicoara, $13 \mathrm{~km}$ de Jussiape na estrada para Morro Branco e Capão

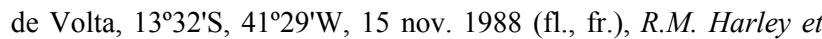
al. 26453 (CEPEC, CTES, SPF); Igaporã, ca. $5 \mathrm{~km}$ a partir do entrocamento da BR-430 na estrada para Tanque Novo, 134' $23^{\circ} \mathrm{S}$, 42 $42^{\prime} 51$ "W, 17 jan. 2004 (fl., fr.), M. Machado \& M.V.M. Oliveira 170 (HUEFS); Ipupiara, $15 \mathrm{~km}$ da cidade, na estrada para Mussambê, 11 ${ }^{\circ} 49^{\prime} 00^{\prime \prime} \mathrm{S}, 42^{\circ} 36^{\prime} 00^{\prime \prime} \mathrm{W}, 26$ jan. 2001 (fl.), M.L. Guedes et al. 7964 (ALCB, CEPEC, CTES, HUEFS); Itapicuru, 4 $\mathrm{km}$ da rodovia Itapicuru-Tobias Barreto, $11^{\circ} 31^{\prime} \mathrm{S}, 38^{\circ} 23^{\prime} \mathrm{W}, 16$ jun. 1994 (fl.), S.C. Sant'Ana et al. 487 (CEPEC, CTES); Jacobina, cruzeiro, $11^{\circ} 10^{\prime} \mathrm{S}, 40^{\circ} 21^{\prime} \mathrm{W}, 19$ abr. 2009 (fl., fr.), M.L. Guedes et al. 14844 (ALCB); Jeremoabo, Baixa dos Queles, 095 $58^{\prime} 60^{\prime \prime} \mathrm{S}$, $38^{\circ} 26^{\prime} 16^{\prime \prime W}, 488$ m, 17 out. 2009 (fl.), E. Melo et al. 6638 (ALCB, HUEFS); Juazeiro, $09^{\circ} 41^{\prime} \mathrm{S}, 40^{\circ} 05^{\prime} \mathrm{W}$, s.d., (fl., fr.), A. Löfgren 990 (RB); Jussiape, 10-15 km a W de Capão de Volta, 1330'S, 4130'W, 20 jan. 1997 (fl., fr.), M.M. Arbo et al. 7583 (CEPEC, CTES, HUEFS); Lagoinha, $16 \mathrm{~km}$ a NW de Lagoinha na estrada para Minas do Mimoso, $10^{\circ} 22^{\prime} \mathrm{S}, 41^{\circ} 20^{\prime} \mathrm{W}, 950-1000 \mathrm{~m}, 4$ mar. 1974 (fl., fr.), R.M. Harley et al. 16715 (CEPEC, CTES, RB); Macaúbas, Poço da Anta, 13º1'S, 42 $41^{\circ} \mathrm{W}, 26$ nov. 2004 (fl., fr.), G. Hatschbach et al. 78582 (CTES, MBM); Mirangaba, 1046'S, 40³8'W, 23 abr. 1981 (fl., fr.), N.W. Fonseca 404 (CTES, HRB, RB, UB); Morro do Chapéu, estrada para o Morrão, $11^{\circ} 33^{\prime} \mathrm{S}$, $41^{\circ} 09^{\prime} \mathrm{W}, 22$ out. 2011 (fl., fr.), M.L. Guedes et al. 19302 (ALCB);

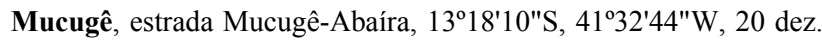
2007 (fl.), M. Ibrahim et al. 34 (HUEFS); Nova Soure, na estrada para Cipó, BR-110, 11 $23^{\prime} \mathrm{W}, 38^{\circ} 48^{\prime} \mathrm{W}, 23$ ago. 1996 (fl., fr.), L.P. Queiroz \& N.S. Nascimento 4548 (ALCB, CTES, HUEFS, MBM, RB, SP); Palmeiras, Pau Ferro, $2 \mathrm{~km}$ do município, $12^{\circ} 52^{\prime} \mathrm{S}$, 4155W, 700 m, 4 abr. 1996 (fl., fr.), F. França et al. 1579 (CTES, HUEFS); Paulo Afonso, Raso da Catarina, $09^{\circ} 04^{\prime} \mathrm{S}, 38^{\circ} 22^{\prime} \mathrm{W}, 10$ nov. 2010 (fl., fr.), E. Barbosa et al. 2872 (MBM); Piatã,

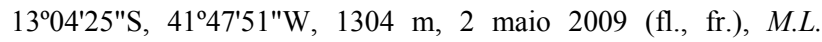
Guedes et al. 16341 (ALCB); Pilão Arcado, Lu Pequeno, estrada

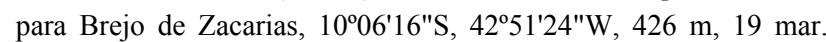
2006 (fl., fr.), E.B. Souza et al. 1571 (CTES, HUEFS); Rio de Contas, trilha da estrada Real, 133' $34^{\prime} \mathrm{S}, 41^{\circ} 48^{\prime} \mathrm{W}, 1$ fev. 2005 (fl., fr.), J. Paula-Souza et al. 5268 (CTES, ESA); Santa Brígida, ca 11 $\mathrm{km}$ do povoado dos 40, 09 $44^{\prime} 09^{\prime \prime} \mathrm{S}, 38^{\circ} 18^{\prime} 03^{\prime \prime} \mathrm{W}, 390 \mathrm{~m}, 29$ nov. 2009 (fl., fr.), E. Melo et al. 7305 (ALCB, HUEFS); Seabra, ca. 7 $\mathrm{km}$ a W da cidade, $12^{\circ} 25^{\prime} 50^{\prime \prime} \mathrm{S}, 41^{\circ} 49^{\prime} 34 " \mathrm{~W}, 1074 \mathrm{~m}, 12$ abr. 2005 (fl., fr.), E.B. Souza et al. 1119 (HUEFS); Sento Sé, Serra dos

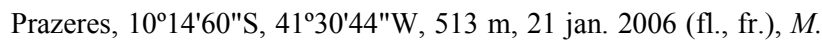
Oliveira 4765 (CTES, HVASF); Tanquinho, $15 \mathrm{~km}$ a $\mathrm{N}$ do

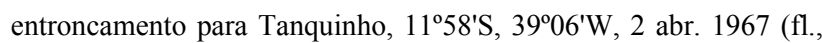
fr.), A. Krapovickas 12807 (CTES); Tucano, povoado Pedra

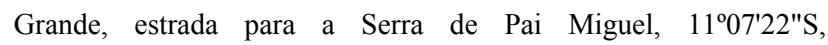
38 $46^{\prime} 23^{\prime \prime W}, 233$ m, 17 abr. 2008 (fl.), L.P. Queiroz et al. 13678 (HUEFS); Umburanas, estrada Cachoeirinha-Delfino, ca. $2 \mathrm{~km}$ de

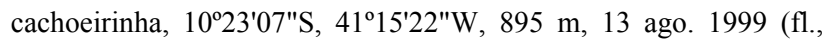
fr.), E. Melo et al. 2830 (CTES, HUEFS); Xique-Xique, Serra da Tiririca, $10^{\circ} 49^{\prime} \mathrm{S}, 42^{\circ} 43^{\prime} \mathrm{W}, 12$ maio 1912 (fl.), Zehntner 99-990 (R).

Pode ser reconhecida pelos caules muito ramificados, folhas pequenas e revolutas, geralmente dispostas em braquiblastos axilares ou terminais. Os espécimes se tornam castanho-escuros ou verde-oliva quando secos. As flores foram encontradas abertas até 16:00 hs; visitadas por besouros e aranhas verdes. As folhas exalam odor mentolado, devido aos tricomas glandulares capitado-sésseis. Turnera diffusa se assemelha a $T$. calyptroparca, a qual se diferencia pelas flores brancas com base das pétalas amarela e sementes retas.

Arbo (2000) considerou duas variedades para esta espécie: $T$. diffusa var. diffusa e $T$. diffusa var. aphrodisiaca (Ward) Urb.; apenas a variedade típica ocorre na Bahia. Turnera diffusa var. aphrodisiaca ocorre na América Central e se caracteriza pelas folhas glabras a quase glabras vs. pilosas na variedade típica, e pedúnculos florais geralmente maiores, 1-2 mm vs. 0,5-1(-2) (Arbo 2000).

2.16. Turnera genistoides Cambess. in Saint-Hilaire, Jussieu \& Cambessedes, Fl. Bras. Merid. 2: 220. 1830.

Figuras 10A; Arbo (2008: fig. 28A-L).

Subarbustos ca. $10 \mathrm{~cm}$ alt.; caules estrigosos a esparso-pilosos, tricomas tectores simples. Estípulas ausentes. Folhas com pecíolo até $0,5 \mathrm{~mm}$ compr.; nectários ausentes; lâmina 8-14 × 0,5-1,5 mm, cartácea, discolor, linear, base atenuada, ápice agudo, margens inteiras, fortemente revolutas; face adaxial estrigosa, nervura principal impressa, face abaxial denso-estrigosa, nervura principal proeminente. Inflorescências unifloras, solitárias ou agrupadas no ápice dos ramos; pedúnculo 0,6-1 $\mathrm{mm}$ compr., totalmente adnato ao pecíolo; brácteas ausentes; bractéolas 1,5-4 $\mathrm{mm}$ compr., lineares. Flores heterostilas, epífilas; pedicelo ausente. Cálice 4,4-5,2 $\mathrm{mm}$ compr., externamente denso-estrigoso. Corola 7-6 mm compr., amarela. Filetes ca. $5 \mathrm{~mm}$ compr. em flores longistilas, 2,5-3 $\mathrm{mm}$ compr. em flores brevistilas, esparso-pilosos, base ca. $0,3 \mathrm{~mm}$ adnata ao tubo floral; anteras ca. $1 \mathrm{~mm}$ compr., dorsifixas. Ovário ca. $1 \mathrm{~mm}$ compr., denso-piloso; estiletes 1,7-2 mm compr. em flores brevistilas, 4-5 mm compr. em flores longistilas, hirsutos; estigmas penicelados. Cápsulas 4-4,5 mm compr.; epicarpo liso, densopilosa. Sementes 2-2,3 × 1-1,2 $\mathrm{mm}$, obovoides, curvas, reticuladas; epiderme lisa; calaza pouco proeminente, superfície às vezes côncava.

Ocorre nos campos rupestres de Diamantina, em Minas Gerais (Arbo 2008). O único espécime coletado no estado da Bahia foi obtido na Serra de Sincorá, provavelmente no município de Contendas do Sincorá.

Material examinado - "Sincorâ", nov. 1818, s.d. (fl., fr.), C.F.P. Martius s.n. (M 214549-foto).

Material adicional examinado - BRASIL. MINAS GERAIS: Diamantina, $3,5 \mathrm{~km}$ da rodovia em direção a Biribiri, $18^{\circ} 24^{\prime} \mathrm{S}$, 435'', 6 jul. 1996 (fl., fr.), V.C. Souza et al. 11876 (CTES, ESA).

Trata-se de um subarbusto de pequeno porte, com entrenós muito curtos, e pode ser reconhecido pelas folhas lineares, com margens inteiras, revolutas, cicatrizes foliares salientes e flores com corola 
amarela. O espécime coletado na Bahia data de quase 200 anos (Spix \& Martius 1981), mas há registros recentes para o estado de Minas Gerais, os quais estão restritos aos arredores de Diamantina.

\subsection{Turnera harleyi Arbo, Bonplandia 5(14): 118.} 1981.

Figuras 10B e 33; Arbo (2008: fig. 33A-J); Rocha \& Moreira (2014: fotos 50 e 51).

Arbustos a subarbustos $0,7-1 \mathrm{~mm}$ alt.; caules estrigosos, tricomas tectores simples. Estípulas rudimentares. Folhas com pecíolo 0,3-2,5 mm compr.; nectários até 2 , ca. $1 \mathrm{~mm}$ diâm., apenas nas folhas floríferas; lâmina 4-33 × 0,7-3(-4) mm, cartácea, discolor, linear, lanceolada ou oblanceolada, base atenuada, ápice agudo, margens serrilhadas, revolutas, geralmente com 3 ou 4 pares de dentes obtusos em cada lado da lâmina; face adaxial estrigosa, nervuras impressas, face abaxial denso-estrigosa, nervuras proeminentes. Inflorescências unifloras, solitárias ou reunidas em racemos terminais; pedúnculo 1,5-2,5 $\mathrm{mm}$ compr., 0,5-1,5 $\mathrm{mm}$ adnato ao pecíolo; brácteas ausentes; bractéolas 2-5,5 $\mathrm{mm}$ compr., lineartriangulares. Flores heterostilas, epífilas; pedicelo ausente. Cálice 7-12 $\mathrm{mm}$ compr., externamente estrigoso. Corola $1-1,5 \mathrm{~cm}$ compr., amarela ou amarelo-alaranjada. Filetes 5,5-9 mm compr. em flores brevistilas, 2,5-5,5 $\mathrm{mm}$ compr. em flores longistilas, glabros, base ca. $0,6 \mathrm{~mm}$ adnata ao tubo floral; anteras 0,8-1,2 mm compr., dorsifixas. Ovário 1-1,5 $\mathrm{mm}$ compr., tomentoso; estiletes 1,7-2,7 mm compr. em flores brevistilas, 4-8 mm compr. em flores longistilas, ápice glabro ou esparso-piloso; estigmas ramosos. Cápsulas 4-6 mm diâm.; epicarpo liso, esparsohirsuto. Sementes 2-3 × 0,7-1 mm, obovoides, curvas, reticuladas; epiderme com papilas filiformes; calaza proeminente, superfície côncava.

Rara, endêmica da Bahia (Arbo 2008; Arbo \& Giulietti 2009). C6, F5, G5: cerrados, caatingas, carrascos e campos gerais. Habita áreas abertas, por vezes perturbadas, como margens de rodovias ou trilhas e terrenos baldios. Cresce em substratos arenosos e rochosos, em altitudes de 850-1200 m. Apresenta flores e frutos nos meses de março, abril, julho e agosto.

Material selecionado - Caetité, $9 \mathrm{~km}$ antes de Caetité, estrada saindo de Brejinho das Ametistas, após o posto de mineração, $14^{\circ} 04^{\prime} \mathrm{S}, 4^{\circ} 28^{\prime} \mathrm{W}, 27$ abr. 2013 (fl., fr.), L. Rocha \& $P$. Gomes 428 (CTES, HUEFS, RB); Delfino, Serra do Curral Feio, 8 km NW de Lagoinha na estrada para Minas do Mimoso, $10^{\circ} 24$ 'S, $41^{\circ} 17^{\prime} \mathrm{W}, 850$ m, 5 mar. 1974 (fl., fr.), R.M. Harley 16807 (holótipo CEPEC, isótipos CTES, IPA, RB); Igaporã, BR-430,

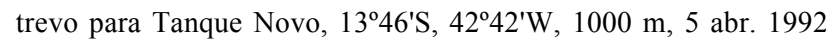
(fl., fr.), G. Hatschbach et al. 56642 (CTES, MBM, UB); Sento Sé, Serra da Linha Branca, 1009'15"S, 4124'30"W, 878 m, 13 ago. 2006 (fl., fr.), J.A. Siqueira-Filho et al. 1715 (HVASF, IPA); Umburanas, estrada indo para Delfino, $10^{\circ} 26^{\prime} 28^{\prime \prime} \mathrm{S}, 41^{\circ} 17^{\prime} 39^{\prime \prime} \mathrm{W}$, 925 m, 16 jul. 2004 (fl., fr.), P. Fiaschi et al. 2487 (CEPEC, CTES, RB, SPF).
São arbustos a subarbustos de pequeno porte, que podem ser reconhecidos principalmente pelas folhas lineares, lanceoladas ou oblanceoladas, de margens fortemente revolutas, serrilhadas, geralmente com 3 ou 4 pares de dentes obtusos de cada lado da lâmina. Quando secos, os espécimes adquirem uma coloração que varia do castanho-dourada a castanho-escura, que auxilia na identificação. Suas flores foram encontradas abertas até 15:00 hs; visitadas por besouros, formigas pretas e vermelhas. Turnera harleyi se assemelha a $T$. melochioides, a qual se diferencia pelas folhas geralmente maiores, elípticas a ovadas, com margens planas e flores menores.

2.18. Turnera hebepetala Urb., Jahrb. Königl. Bot. Gart. Berlin 2: 127. 1883.

Figuras 10C, D e 33; Arbo (2000: fig. 18A-J).

Arbustos 0,5-2 $\mathrm{m}$ alt.; caules denso-pilosos, tricomas tectores simples e glandulares capitadosésseis. Estípulas 2, 1-2 $\mathrm{mm}$ compr. Folhas geralmente dispostas em braquiblastos axilares; pecíolo 0,5-3 mm compr.; nectários ausentes; lâmina 4-45 × 1-11 mm, cartácea, discolor, estreito-obovada, base atenuada, ápice agudo a obtuso, margens serreadas, geralmente revolutas; face adaxial estrigosa, nervuras impressas, face abaxial esparso-pilosa, nervuras avermelhadas e proeminentes. Inflorescências unifloras, solitárias; pedúnculo 1-1,5 mm compr., livre do pecíolo; brácteas ausentes; bractéolas 1,6-5 $\mathrm{mm}$ compr., elípticas ou espatuladas. Flores heterostilas; pedicelo ausente. Cálice 4-5,5 mm compr., externamente esparso-estrigoso. Corola 6-8 $\mathrm{mm}$ compr., branca a creme, base das pétalas amarela. Filetes 4,8-6,5 mm compr. em flores brevistilas, 2-2,5 $\mathrm{mm}$ compr. em flores longistilas, esparso-pilosos, unidos entre si ca. $0,2 \mathrm{~mm}$ na base; livres ou ca. 0,5 $\mathrm{mm}$ adnatos ao tubo floral; anteras $0,8-1 \mathrm{~mm}$ compr., dorsifixas. Ovário 1,5-2 mm compr., denso-estrigoso; estiletes 1,5-2 $\mathrm{mm}$ compr. em flores brevistilas, 3-4 $\mathrm{mm}$ compr. em flores longistilas, esparso-piloso; estigmas penicelados. Cápsulas 4-6 $\mathrm{mm}$ diâm.; epicarpo tenuamente-verrucoso, esparso-piloso. Sementes 1,5-1,8 $\times$ ca. $1 \mathrm{~mm}$, largo-obovoides, retas, reticuladas; epiderme lisa; calaza obtusa, superfície plana.

Ocorre na Bahia, Piauí e Rio de Janeiro, este último com localidade duvidosa (Arbo 2000, 2015).

F4, F5, G5: caatingas e campos rupestres. Foi encontrada em afloramentos rochosos, em altitudes de 550-840 m. Apresenta flores e frutos nos meses de janeiro e abril.

Material selecionado - Bom Jesus da Lapa, Juá, $13^{\circ} 25^{\prime} \mathrm{S}$, 434' 'W, 500 m, 5 abr. 1992 (fl., fr.), G. Hatschbach et al. 56611 (CEPEC, CTES, ESA, HUEFS, MBM, RB, SP, SPF,

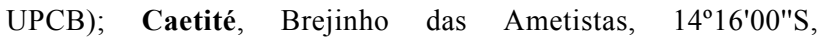
42³1'34"W, 840 m, 10 jan. 2006 (fl., fr.), A.K.A. Santos et al. 561 (HUEFS); Riacho de Santana, Barauninha, 1336'S, 42 $56^{\prime} \mathrm{W}, 550$ m, 19 abr. 1996 (fl., fr.), G. Hatschbach et al. 65059 (CEPEC, CTES, MBM) 


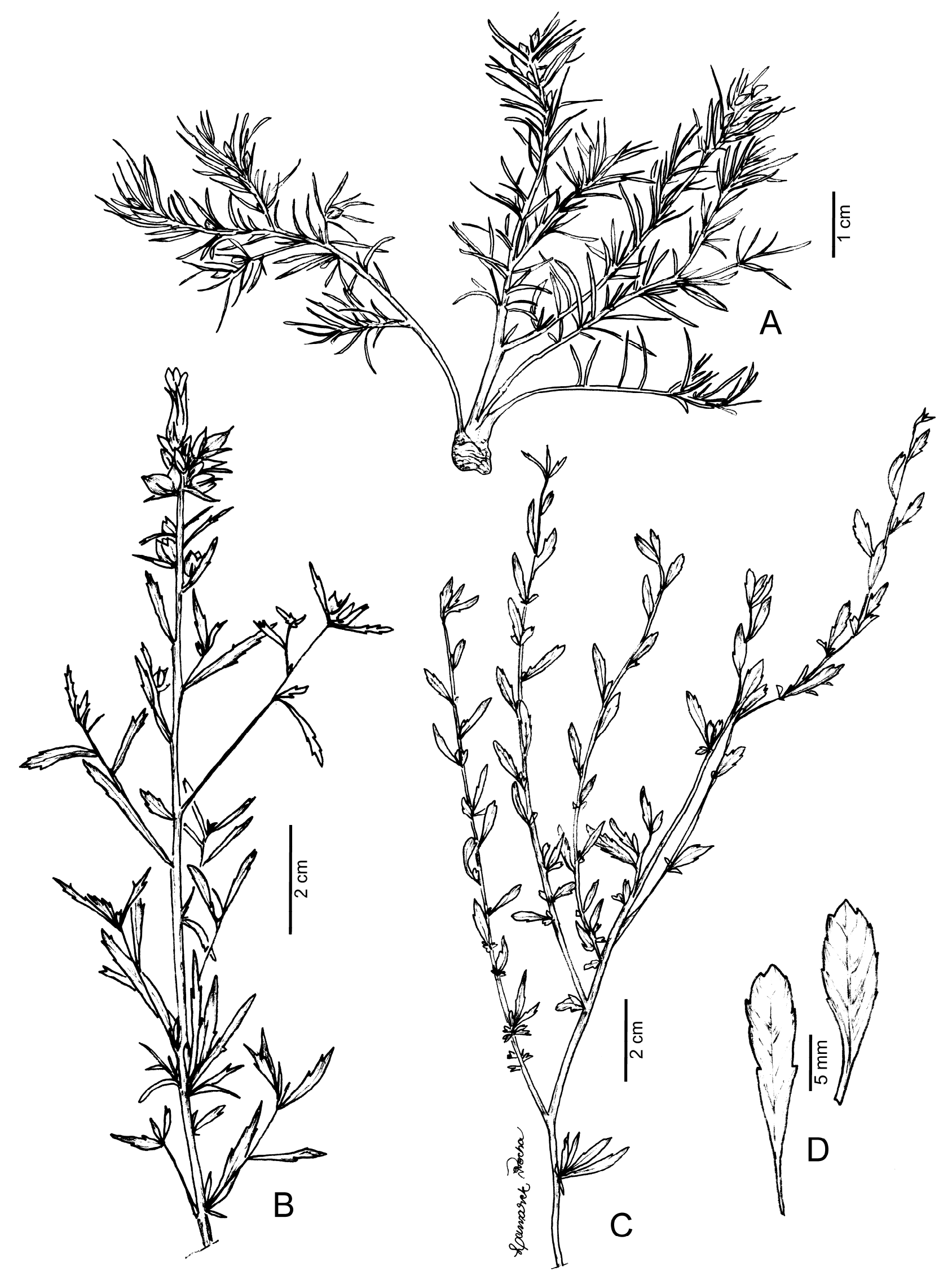

Figura 10. A. Turnera genistoides: porção do hábito com ramos reprodutivos (Martius s.n.). B. T. harleyi: ramo reprodutivo (Queiroz 5237). C, D. T. hebepetala: C- ramo estéril; D- folhas (face adaxial) (Hatschbach 65059). 
Pode ser reconhecida pelas folhas estreitoobovadas, geralmente dispostas em braquiblastos axilares, flores com pedúnculos curtos e corola branca a creme, com base das pétalas amarela. Os filetes são discretamente unidos entre si na base, que pode ser visualizada apenas com auxílio de microscópio estereoscópio, às vezes apenas mediante cortes anatômicos seriados (Arbo 2000). Turnera hebepetala se assemelha a $T$. calyptroparpa, a qual se diferencia principalmente pelas folhas obovadas, elípticas, raro ovadas e flores com pedúnculos geralmente mais longos.

\subsection{Turnera hermannioides Cambess. in Saint-} Hilaire, Jussieu \& Cambessedes, Fl. Bras. Merid. 2: 218. 1830.

Figuras 11 e 34; Arbo (2005: fig. 28A-G); Rocha \& Moreira (2014: fotos 52 e 53).

Subarbustos ou arbustos $0,2-1 \mathrm{~m}$ alt.; caules tomentosos, tricomas tectores estrelados, simples e glandulares microcapitados. Estípulas 2, rudimentares. Folhas com pecíolo $1-9 \mathrm{~mm}$; nectários 1 ou 2 pares, 0,5-1 mm diâm.; lâmina $0,6-6 \times 0,5-2,5 \mathrm{~cm}$, papirácea, concolor a ligeiramente discolor, obovada, elíptica, raro ovada, base cuneada a atenuada, ápice agudo a obtuso, margens simples a duplamente serreado-crenadas, planas a ligeiramente revolutas; face adaxial denso-pilosa, nervuras ligeiramente impressas, face abaxial tomentosa, nervuras proeminentes. Inflorescências unifloras, solitárias ou agrupadas no ápice dos ramos; pedúnculo 2-6 $\mathrm{mm}$ compr., totalmente adnato ao pecíolo; brácteas ausentes; bractéolas 2-5 $\mathrm{mm}$ compr., lineartriangulares. Flores heterostilas, epífilas; pedicelo ausente. Cálice 7,5-18 $\mathrm{mm}$ compr., externamente tomentoso. Corola 1,3-3 cm, creme, base das pétalas amarelo-escura, às vezes com estrias marrons. Filetes 7,5-10 mm compr. em flores brevistilas, $3,5-5,5 \mathrm{~mm}$ compr. em flores longistilas, glabros, margens $2-3 \mathrm{~mm}$ adnatas a unha das pétalas, formando sacos nectaríferos; anteras $2-3,3 \mathrm{~mm}$ compr., basifixas. Ovário 1-2 mm compr., tomentoso; estiletes 3,5-4 mm compr. em flores brevistilas, $6-10 \mathrm{~mm}$ compr. em flores longistilas, esparso-pilosos; estigmas penicelados. Cápsulas 4-6 $\mathrm{mm}$ diâm.; epicarpo verrucoso, denso-hirsuto. Sementes $2-3 \times 1-1,3 \mathrm{~mm}$, oblongas, retas ou ligeiramente curvas, tenuamente reticuladas; epiderme lisa; calaza proeminente, umbilicada, superfície côncava.

Ocorre no Centro-Oeste (Goiás), Nordeste (Piauí, Pernambuco, Bahia e Sergipe), Norte (Tocantins) e Sudeste (Minas Gerais e Espírito Santo) (Arbo 2015). B5, B6, B7, C5, C7, D3, D4, D5, D6, D7, D10, E3, E4, E6, E7, F3, F4, F5, F6, F7, G3, G5, G6, H9, J8: caatingas, cerrados, carrascos, campos rupestres, campos gerais, áreas de transição caatinga/cerrado, dunas, restingas, matas ciliares e matas estacionais densas. Espécie ruderal, encontrada em áreas abertas, quase sempre perturbadas, em margens de rodovias e zonas urbanas. Cresce em substratos rochosos, arenosos e argilosos, em altitudes até $1080 \mathrm{~m}$. Apresenta flores e frutos durante o ano todo.

Material selecionado - Angical, Assentamento Gameleira/Santa Luzia, $11^{\circ} 54^{\prime} 33^{\prime \prime} \mathrm{S}, 4^{\circ} 48^{\prime} 24^{\prime \prime} \mathrm{W}$, s.d. (fl., fr.), $K$. Yoshida-Arns et al. s.n. (UFP 61056); Aracatu, arredores, $14^{\circ} 42^{\prime} \mathrm{S}$,

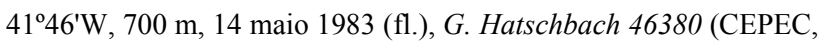
CTES, MBM, SP, SPF); Barra, Morrinho, $11^{\circ} 08^{\prime} \mathrm{S}, 43^{\circ} 17^{\prime} \mathrm{W}, 14$ nov. 2009 (fl., fr.), A.P. Prata et al. 1836 (ASE, HUEFS); Barra do Mendes, estrada para Ipupiara, $11^{\circ} 47^{\prime} 16^{\prime \prime} \mathrm{S}, 42^{\circ} 11^{\prime} 25^{\prime \prime} \mathrm{W}, 850 \mathrm{~m}, 17$ dez. 2009 (fl., fr.), E. Melo et al. 7671 (ALCB, HUEFS); Barreiras, pátio do hotel Barreiras, $12^{\circ} 09^{\prime} \mathrm{S}, 44^{\circ} 59^{\prime} \mathrm{W}, 450 \mathrm{~m}, 30$ mar. 1983 (fl., fr.), A. Krapovickas et al. 38702 (CEN, CTES); Belmonte, SW da periferia da cidade, $15^{\circ} 52^{\prime} \mathrm{S}, 38^{\circ} 53^{\prime} \mathrm{W}, 26$ mar. 1974 (fl., fr.), R.M. Harley et al. 17433 (CEPEC, CTES, IPA, RB); Bom Jesus da Lapa, ca. $14 \mathrm{~km}$ ao $\mathrm{S}$ do entroncamento para Bom Jesus da Lapa na estrada para Malhada, $13^{\circ} 40^{\prime} \mathrm{S}, 43^{\circ} 36^{\prime} \mathrm{W}, 11$ fev. 2000 (fl., fr.), L.P. Queiroz et al. 5858 (ALCB, CEPEC, CTES, HUEFS); Caetité, BR$030,7 \mathrm{~km}$ a $\mathrm{E}$ de Caetité, estrada para Brumado, $14^{\circ} 05^{\prime} \mathrm{S}, 42^{\circ} 26^{\prime} \mathrm{W}$, 22 jan. 1997 (fl., fr.), M.M. Arbo et al. 7641 (ALCB, CEPEC, CTES); Caraíbas, BA-262, $55 \mathrm{~km}$ a SE de Brumado, estrada para

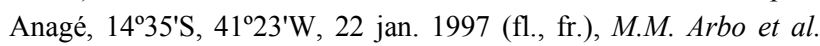
7658 (CEPEC, CTES); Caravelas, BR-418 a $16 \mathrm{~km}$ do entroncamento com a BA-001, 17 $433^{\prime} \mathrm{S}, 39^{\circ} 15^{\prime} \mathrm{W}, 18$ mar. 1978 (fl., fr.), S.A. Mori et al. 9671 (CEPEC, CTES, RB); Casa Nova, fazenda Santarém, $09^{\circ} 52^{\prime} \mathrm{S}, 41^{\circ} 35^{\prime} \mathrm{W}, 29$ nov. 2003 (fl., fr.), L.P. Queiroz et al. 8045 (HUEFS); Cocos, ca. $5 \mathrm{~km} \mathrm{~W}$ da cidade, $14^{\circ} 18^{\prime} \mathrm{S}, 44^{\circ} 53^{\prime} \mathrm{W}, 530$ m, 17 mar. 1972 (fl., fr.), W.R. Anderson et

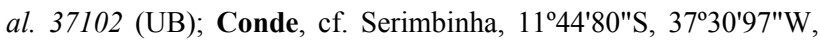
16 jan. 2003 (fl., fr.), N.G. Jesus et al. 1650 (ALCB, HUEFS);

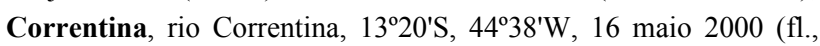
fr.), G. Hatschbach et al. 71274 (CTES, MBM); Feira da Mata, Médio São Francisco próximo ao rio Carinhanha, $14^{\circ} 13^{\prime} 54$ "S,

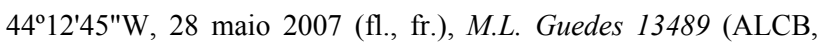
BRBA, HUEFS); Guanambi, BR-030, $15 \mathrm{~km} \mathrm{~N}$ da cidade, $14^{\circ} 13^{\prime} \mathrm{S}$, 42 $46^{\prime} \mathrm{W}, 900$ m, 19 abr. 1996 (fl., fr.), G. Hatschbach et al. 65044 (CEPEC, CTES, ESA, MBM, UPCB); Ibitiara, Olhos d'Água do Seco, $12^{\circ} 39^{\prime} \mathrm{S}, 42^{\circ} 13^{\prime} \mathrm{W}$, set. 1957 (fl., fr.), R.P. Lordêlo 57-736 (ALCB); Ibotirama, 12 ${ }^{\circ} 11^{\prime} \mathrm{S}, 4^{\circ} 13^{\prime} \mathrm{W}, 19$ mar. 1982 (fl., fr.), $A$. Krapovickas et al. 37891 (CEN, CTES); Igaporã, BR-430, 7 km NW da cidade, 134' S, 42 $42^{\prime} \mathrm{W}, 500$ m, 5 abr. 1992 (fl., fr.), G. Hatschbach et al. 56625 (CTES); Itaberaba, 12 $311^{\prime} \mathrm{S}, 40^{\circ} 17^{\prime} \mathrm{W}, 22$ abr. 1984 (fl., fr.), L. Noblick et al. 3148 (CEPEC, CTES, HUEFS); Itaetê, área urbana, 12 $2^{\circ} 59^{\prime} \mathrm{S}, 40^{\circ} 58^{\prime} \mathrm{W}, 19$ jan. 2012 (fl., fl.), $L$. Rocha et al. 362 (CTES, HUEFS); Jacobina, Serra do Tombador, $11^{\circ} 18^{\prime} \mathrm{S}, 40^{\circ} 05^{\prime} \mathrm{W}, 4$ dez. 2003 (fl., fr.), E.B. Miranda et al. 592 (HUEFS); Jaguarari, Lagoa da Onça, 10¹4'48"S, 4009'14"S, 600 m, 29 jan. 2009 (fl., fr.), J.R. Maciel et al. 734 (CTES, HVASF); Juazeiro, UNIVASF, campus Juazeiro, 09²4'45"S, 40³1'02"W, 374 m, 16 out. 2008 (fl., fr.), J. Antunes 81 (CTES, HVASF, IPA); Lençóis, BR-242, 3-8 $\mathrm{km}$ a W da divisa para Lençóis, $12^{\circ} 28^{\prime} \mathrm{S}$, $41^{\circ} 22^{\prime} \mathrm{W}, 880$ m, 26 nov. 1992 (fl., fr.), M.M. Arbo et al. 5791 (CTES, HUEFS, SPF); Licínio de Almeida, subida para área do Saco da Onça, 14'44'44"S, 42³4'23"W, 932 m, 5 abr. 2013 (fl., fr.), L. Rocha et al. 399 (ALCB, HUEFS); Maracás, BA-026, a 17 km da cidade, 134' $\mathrm{S}, 40^{\circ} 43^{\prime} \mathrm{W}, 7$ abr. 2013 (fl., fr.), L. Rocha et al. 407 (ALCB, HUEFS, SPF); Marcionílio Souza, Machado Portela, Pedra da Bica, 1310'10"S, 4045'59"W, 555 m, 7 jul. 2009 (fl., fr.), C.N. Fraga et al. 2626 (CTES, HUEFS, RB); Morpará, fazenda 


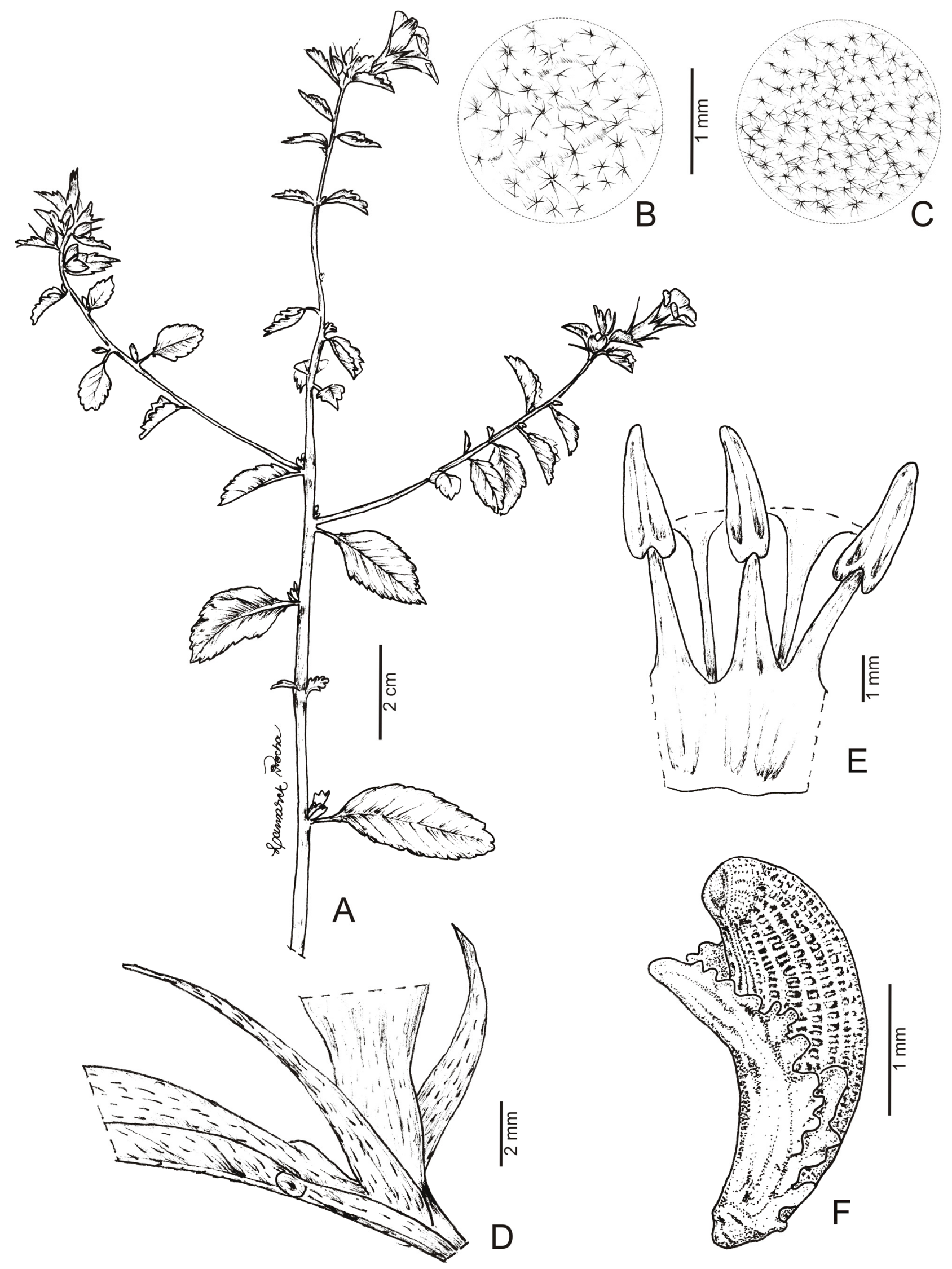

Figura 11. Turnera hermannioides: A- ramo reprodutivo; B- detalhe na face adaxial da folha; C- detalhe na face abaxial da folha; D- detalhe da inflorescência mostrando as bractéolas; E- flor dissecada evidenciando parte do androceu (flor longistila); F- semente (Rocha 376). 
São Domingos, $11^{\circ} 38^{\prime} \mathrm{S}, 43^{\circ} 02^{\prime} \mathrm{W}, 430$ m, 20 mar. 1984 (fl., fr.), $A$. Salgado-Odilon \& H.P. Bautista 321 (RB); Morro do Chapéu, BA-052, 8-9 km da cidade, na direção de Feira de Santana, $11^{\circ} 55^{\prime} \mathrm{S}$, 41ํ1' 'W, 15 abr. 1991 (fl., fr.), G.L. Esteves \& R.P. Lyra-Lemos 2522 (CTES, HST, SPF); Mucugê, estrada para o vale do Guiné, $13^{\circ} 00^{\prime} \mathrm{S}, 41^{\circ} 37^{\prime} \mathrm{W}, 17$ jan. 2012 (fl., fl.), L. Rocha et al. 352

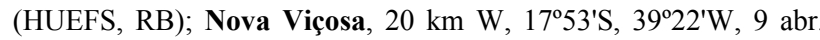
1984 (fl., fr.), G. Hatschbach 47755 (CEPEC, CTES, MBM, RB);

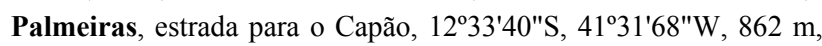
29 abr. 2012 (fl., fl.), L. Rocha \& I. Souza 367 (CTES, HUEFS, RB, $\mathrm{SPF}$ ); Pilão Arcado, $1 \mathrm{~km}$ depois da ponte sobre o riacho de lage, $30 \mathrm{~km}$ de Remanso na estrada para Pilão Arcado, 09² $45^{\prime} 32^{\prime \prime S}$, 42 ${ }^{\circ} 17^{\prime} 53 " \mathrm{~W}, 437$ m, 28 abr. 2001 (fl., fr.), L.P. Queiroz et al. 6577 (ALCB, HUEFS); Rio de Contas, $36 \mathrm{~km}$ de Jussiape, próximo a entrada de Rio de Contas, 13 $34^{\circ} \mathrm{S}, 41^{\circ} 48^{\prime} \mathrm{W}, 1080 \mathrm{~m}, 30$ jan. 2005 (fl., fr.), J. Paula-Souza et al. 5060 (CTES, ESA); Rodelas, 13050'S, 46050'W, 25 fev. 1988 (fl., fr.), R. Orlandi 845 (HRB, RB); São Desidério, Ribeirão Grande, $12^{\circ} 21^{\prime} \mathrm{S}, 4^{\circ} 58^{\prime} \mathrm{W}, 24$ jul. 2008 (fl., fr.), A.M. Miranda \& J. Ferraz 5823 (ALCB, HST); Seabra, BR-242, $12^{\circ} 28^{\prime} \mathrm{S}, 41^{\circ} 44^{\prime} \mathrm{W}, 14$ mar. 1984 (fl., fr.), H.P. Bautista 950 (CEPEC, RB); Senhor do Bonfim, Carrapichel, 10²2'47"S, 4009'23"W, 538 m, 29 jul. 2005 (fl., fr.), P.D. Carvalho et al. 183 (HUEFS); Tanhaçu, $26 \mathrm{~km}$ E de Brumado, estrada para Sussuarana, $14^{\circ} 12^{\prime} \mathrm{S}, 4^{\circ} 26^{\prime} \mathrm{W}, 500 \mathrm{~m}, 22$ nov. 1992, M.M. Arbo et al. 5680 (CTES, HUEFS, SPF); Xique-Xique, assentamento Picada, $10^{\circ} 49^{\prime} \mathrm{S}, 42^{\circ} 43^{\prime} \mathrm{W}, 8$ out. 2011 (fl., fr.), J. Cordeiro et al. 4330 (MBM).

Pode ser reconhecida pelas flores de corola creme, com base das pétalas amarelo-escura, às vezes com estrias marrons, também pelas sementes com calaza umbilicada. É uma das poucas espécies do gênero que apresenta tricomas tectores estrelados, são adensados principalmente nos caules jovens e na face abaxial das folhas, conferindo uma coloração verde-amarelada aos espécimes. As flores foram encontradas abertas até 14:00 hs, visitadas por aranhas verdes e diversos insetos: abelhas (Trigona spp.), vespas, moscas, besouros e borboletas. Algumas espécies de formigas se alimentam do néctar dos nectários extraflorais, principalmente nas folhas terminais. Turnera hermannioides se assemelha a T. scabra, a qual se diferencia pela ausência de tricomas estrelados e sementes com calaza obtusa e superfície plana.

\subsection{Turnera hindsiana Benth., Bot. Voy. Sulphur:} 101.1845.

Figuras 12 e 34; Arbo (1997: fig. 6A-G).

Arbustos ca. $2 \mathrm{~m}$ alt.; caules glabros a esparsopilosos, tricomas tectores simples. Estípulas 2, 1-2 mm compr. Folhas com pecíolo 2-3 mm compr.; nectários ausentes; lâmina 2-5,5 × 1-3 cm, cartácea, ligeiramente discolor, elíptica a elíptico-ovada, base cuneada, ápice agudo, margens serrilhadas, planas; face adaxial glabra a esparso-estrigosa, nervuras ligeiramente impressas, face abaxial glabra a esparsopilosa, nervuras proeminentes. Inflorescências unifloras, solitárias ou dispostas em braquiblastos axilares; pedúnculo 1-2 mm compr., livre do pecíolo; brácteas ausentes; bractéolas 2, 0,5-2 $\mathrm{mm}$ compr., estreito triangulares, na articulação do pedúnculo com pedicelo. Flores heterostilas; pedicelo 2,5-4 $\mathrm{mm}$ compr. Cálice 4-6 mm compr., externamente densopiloso. Corola 3-6 $\mathrm{mm}$ compr., amarela; ápice da unha com lígula ca. 0,2 mm compr., filamentosa. Filetes 2,5-3 mm compr. em flores brevistilas, ca. $2,5 \mathrm{~mm}$ compr. em flores longistilas, base ca. $0,5 \mathrm{~mm}$ adnata ao tubo floral; anteras 0,7-1,5 $\mathrm{mm}$ compr., basifixas. Ovário ca. 1,5 mm compr., glabro; estiletes ca. 1,5 mm compr. em flores longistilas, ca. 1,5 mm compr. em flores longistilas, base denso-pilosa; estigmas penicelados. Cápsulas 5-6 $\mathrm{mm}$ diâm.; epicarpo tuberculado-crestado, glabro. Sementes ca. $3 \times 1-1,4$ $\mathrm{mm}$, obovoides, retas, reticuladas; epiderme com papilas filiformes; calaza proeminente, superfície côncava.

Ocorre no Maranhão, Minas Gerais e Bahia (Arbo 2015). C5: caatingas. Foi encontrada apenas nas matas ciliares do rio São Francisco. Apresenta flores e frutos em fevereiro.

Material examinado - Barra, Ibiraba (= Icatu), estrada para

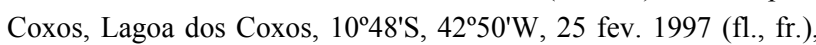
L.P. Queiroz 4851 (CTES, HUEFS, UB, UPCB).

Arbo (1997) reconheceu duas subespécies para $T$. hindsiana: $T$. hindsiana subsp. hindsiana e $T$. hindsiana subsp. brachyantha Arbo; apenas esta última ocorre na Bahia, podendo ser reconhecida pelos pedicelos bem desenvolvidos, ovário glabro e frutos com epicarpo tuberculado-crestado. A subespécie típica é endêmica do Equador e se diferencia principalmente pela corola maior, 6-8,5 $\mathrm{mm}$ compr. (vs. 3-6 mm compr. na subespécie brachyantha).

2.21. Turnera involucrata Arbo, Bonplandia 14: 150 . 2005.

Figuras 13A, B e 35; Arbo (2005: fig. 16A-I); Rocha \& Moreira (2014: fotos 54 e 55).

Arbustos 0,8-1,3 m alt.; caules esparso-pilosos, tricomas tectores simples e glandulares microcapitados. Estípulas 2, 2-5 mm compr. Folhas com pecíolo 1,5-5 mm compr.; nectários ausentes; lâmina 1,4-6 × 0,9-2,7 $\mathrm{cm}$, cartácea, discolor, ovada, elíptica ou obovada, base arredondada a cuneada, ápice agudo a obtuso, margens serreado-crenadas, planas; face adaxial esparso-pilosa, nervuras impressas, face abaxial denso-pilosa a esparso-pilosa, verde-opaca, nervuras proeminentes. Inflorescências unifloras, solitárias; pedúnculo ca. 2 $\mathrm{mm}$, adnato ao pecíolo da bráctea; brácteas 6-10 $\times$ 6,5-12 mm, largo-ovadas, foliáceas, nectários ausentes; bractéolas 8-8,5 × 7,5-8 mm, largo-ovadas. Flores heterostilas, epífilas; pedúnculo ausente. Cálice 8-10,5 mm compr., externamente glabro ou com raros tricomas, apenas nos lacínios. Corola 9,5-15 $\mathrm{mm}$ compr., amarela ou amarelo-alaranjada. Filetes 7,5-8 mm compr. em flores brevistilas, ca. $4 \mathrm{~mm}$ compr. em flores longistilas, glabros, margens 3-3,5 mm adnatas a unha das pétalas, formando sacos nectaríferos; anteras 1,2-1,4 mm compr., dorsifixas. Ovário 1,5-1,8 mm compr., tomentoso; estiletes ca. $2,3 \mathrm{~mm}$ compr. em 


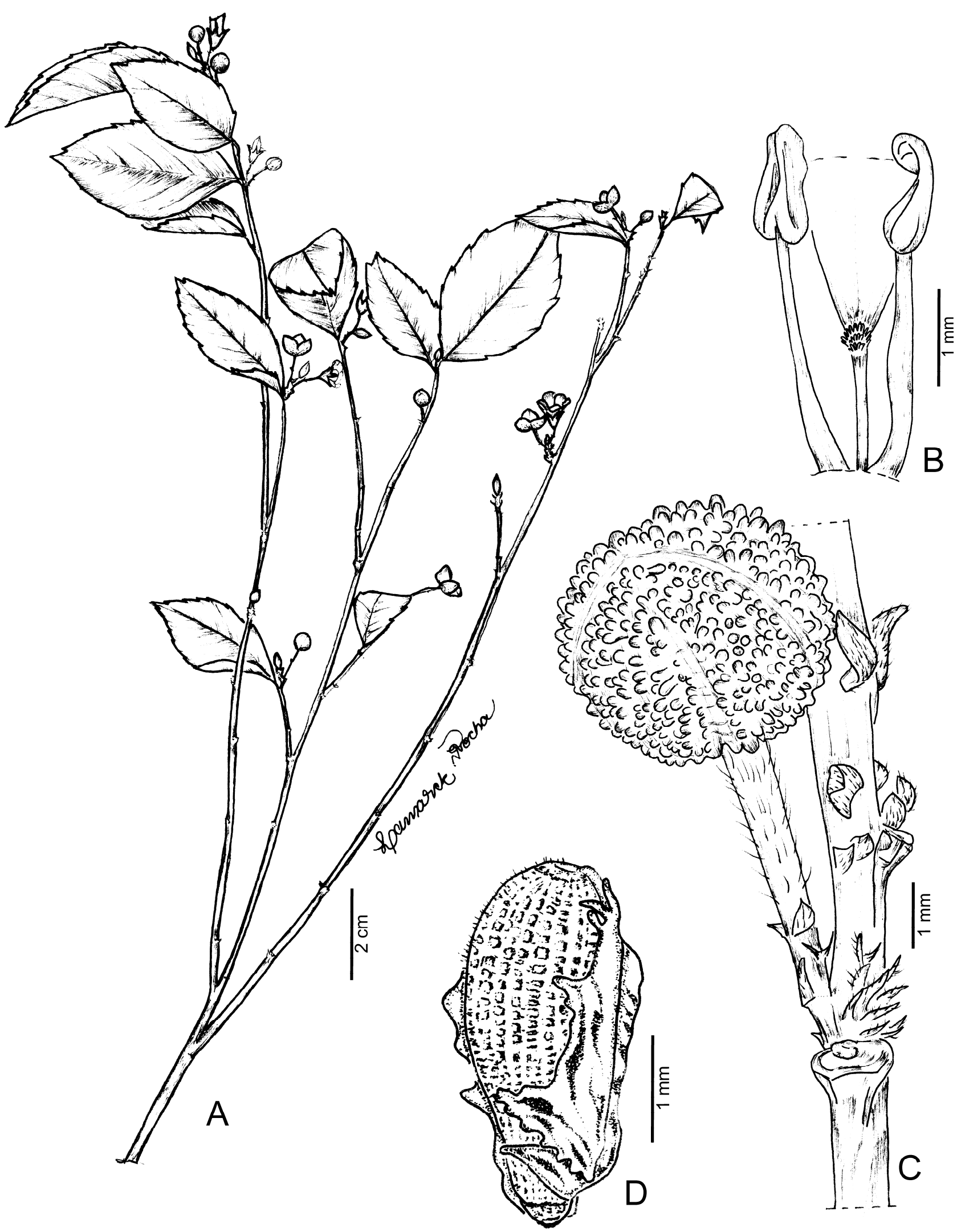

Figura 12. A-D. Turnera hindsiana: A- ramo reprodutivo; B- flor dissecada evidenciando dois estames, detalhe na unha das pétalas com lígula (flor brevistila); C- porção do ramo com fruto; D- semente (Queiroz 4851).

flores brevistilas, ca. $5 \mathrm{~mm}$ compr. em flores longistilas, glabros ou pubescentes; estigmas penicelados. Cápsulas 4,2-4,5 mm diâm.; epicarpo verrucoso, pubescente.
Sementes ca. $2,3 \times 1 \mathrm{~mm}$, obovoides, curvas, reticuladas; epiderme com papilas filiformes; calaza pouco proeminente, superfície côncava. 
Rara, endêmica do sudoeste da Bahia (Arbo \& Giulietti 2009). G5: caatinga arbórea. Habita áreas de vegetação fechada, sombreadas, ou margens de rodovias e trilhas. Encontrada em substratos argilosos, em altitudes de 500-900 m. Apresenta flores e frutos de novembro a abril

Material examinado - Caetité, $20 \mathrm{~km}$ a W de Caetité, estrada para Brumado, $14^{\circ} 08^{\prime} \mathrm{S}, 42^{\circ} 15^{\prime} \mathrm{W}, 500 \mathrm{~m}, 20$ nov. 1992 (fl., fr.), M.M. Arbo et al. 5649 (holótipo SPF, isótipos CTES, HUEFS, MBM, NY-foto); Licínio de Almeida, trilha da mata do Xaxá, 14³0'09"S, 42³2'48"W, 924 m, 5 abr. 2013 (f1.), L. Rocha et al. 391 (ALCB, CTES, HUEFS).

Pode ser reconhecida principalmente pelas brácteas e bractéolas foliáceas, que formam um invólucro na base da flor, além da corola amarela ou amarelo-alaranjada. As margens dos estames são adnatas à unha das pétalas, formando cinco volumosos sacos nectaríferos, característicos dessa espécie. Turnera involucrata assemelha-se a $T$. cearensis, a qual se diferencia pela presença de tricomas tectores estrelados no indumento e ausência de brácteas e bractéolas foliáceas.

\subsection{Turnera joelii Arbo, Bonplandia 7: 78. 1993.}

Figuras 35; Arbo (2005: fig. 30A-L); Rocha \& Moreira (2014: fotos 56 e 57).

Arbustos 20-80 cm alt.; caules estrigosos, tricomas tectores simples e glandulares microcapitados e claviformes. Estípulas 2, rudimentares. Folhas com pecíolo 1-13 mm compr.; nectários 2, 0,7-1,3 mm diâm.; lâmina 1-8,5 × 0,4-4 cm, papirácea, concolor, ovada, elíptica a obovada, base atenuada, ápice agudo a obtuso, margens planas, serreadas a serreado-crenadas, 1/3 proximal inteiro; face adaxial esparso-estrigosa, nervuras ligeiramente impressas, face abaxial estrigosa, nervuras proeminentes. Inflorescências unifloras, solitárias ou agrupadas no ápice dos ramos; pedúnculo 2-4,5 mm compr., totalmente adnato ao pecíolo; brácteas ausentes; bractéolas 5,5-15 mm compr., lineartriangulares. Flores heterostilas, epífilas; pedúnculo ausente. Cálice 1,3-1,7 cm compr., externamente estrigoso. Corola 1,9-2,8 cm compr., amarela. Filetes 9$10,5 \mathrm{~mm}$ compr. em flores brevistilas, 4-6,5 mm compr. em flores longistilas, glabros, margens 2-3 mm adnatas a unha das pétalas, formando sacos nectaríferos; anteras ca. 1,3 mm compr., basifixas. Ovário 1-2,5 mm compr., tomentoso; estiletes 3,5-4 $\mathrm{mm}$ compr. em flores brevistilas, 8,5-11 $\mathrm{mm}$ compr. em flores longistilas, esparso-pubescentes; estigmas penicelados. Cápsulas 6 7 mm diâm.; epicarpo verrucoso, denso-piloso. Sementes 2,4-3 × 0,7-1 mm, obovoides, curvas, reticuladas; epiderme lisa; calaza proeminente, superfície côncava, umbilicada.

Endêmica da Bahia, conhecida apenas para a região Central-Norte do Estado. B7, B8, C7, C8, D6: caatingas e campos rupestres. Ocorre em áreas abertas, às vezes perturbadas, como margens de trilhas e rodovias. Cresce em substratos argilosos e rochosos, em altitudes de 850-1200 m. Apresenta flores e frutos durante a maior parte do ano.
Material selecionado - Bendegó, saída para Uauá, perto da rodovia, $09^{\circ} 57^{\prime} 47^{\prime \prime} \mathrm{S}, 39^{\circ} 10^{\prime} 10^{\prime \prime} \mathrm{W}, 23$ fev. 2000 (fl., fr.), A.M. Giulietti \& R.M. Harley 1762 (CTES, HUEFS); Cafarnaum, Mulungu do Morro, $11^{\circ} 41^{\prime} \mathrm{S}, 41^{\circ} 28^{\prime} \mathrm{W}, 13$ out. 1981 (fl., fr.), G. Hatschbach 44230 (CEPEC, CTES, MBM, SPF); Campo Formoso, 10 $17^{\prime} \mathrm{S}, 40^{\circ} 39^{\prime} \mathrm{W}, 21$ abr. 1981 (fl., fr.), W.N. Fonseca 374 (ALCB, CTES, RB, UB); Canudos, ca. $13 \mathrm{~km}$ ao $\mathrm{S}$ da cidade, na estrada para Rosário, $10^{\circ} 00^{\prime} 42^{\prime \prime S}, 39^{\circ} 00^{\prime} 09^{\prime \prime W}, 504 \mathrm{~m}, 19$ fev. 2004 (fl., fr.), R.M. Harley et al. 54908 (CTES, HUEFS); Curaçá, Próximo à Gruta, 09¹9'50"S, 39³0'56"W, 13 mar. 2011 (fl., fr.), $E$.

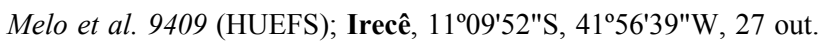
2009 (fl., fr.), F.S. Gomes et al. 346 (ALCB, HUEFS); João Dourado, estrada próxima de Belo Campo, fazenda João Neto,

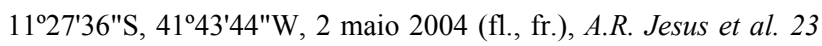
(HUEFS); Juazeiro, $29 \mathrm{~km} \mathrm{~S}$ da cidade, BR-407, 09²48S, 40 $20^{\prime} \mathrm{W}$, 410 m, 11 abr. 1983 (fl., fr.), A. Krapovickas et al. 38793 (holótipo CTES, isótipos CEN, K-foto, MBM, foto-NY); Morro do Chapéu,

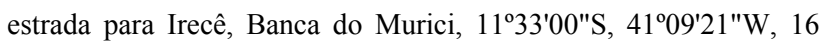
maio 2008 (fl., fr.), F. França et al. 5683 (HUEFS); Rodelas, Salgado do Melão, $09^{\circ} 18^{\prime} \mathrm{S}, 38^{\circ} 40^{\prime} \mathrm{W}, 350$ m, 7 abr. 1972 (fl., fr.), $B$. Pickersgill et al. Ru72-87 (IPA); São Gabriel, fazenda Boa Sorte, $11^{\circ} 01^{\prime} \mathrm{S}, 41^{\circ} 39^{\prime} \mathrm{W}, 800 \mathrm{~m}, 5$ abr. 2009 (fl.), R.F. Machado et al. 215 (HUEFS); Souto Soares, $10 \mathrm{~km}$ antes da cidade, $12^{\circ} 00^{\prime} \mathrm{S}, 41^{\circ} 40^{\prime} \mathrm{W}$, 4 fev. 1973 (fl. fr.), G.K. Gottsberger \& I.S. Gottsberger 11-4273 (ULM-foto).

Pode ser reconhecida pelas folhas geralmente grandes, delicadas quando secas, flores vistosas e heterostilas, de corola amarela, além das sementes com calaza proeminente, com superfície côncava e umbilicada. As flores exalam odor agradável. Assemelha-se a $T$. simulans e $T$. coriacea Arbo; a primeira se diferencia principalmente pelas folhas cartáceas, geralmente menores; a segunda é endêmica dos campos rupestres e cerrados de Minas Gerais e diferencia-se pelas folhas coriáceas, nectários geralmente maiores (até 1,8 mm diâm.) e avermelhados e base das pétalas às vezes escura.

2.23. Turnera lamiifolia Cambess. in Saint-Hilaire, Jussieu \& Cambessedes, Fl. Bras. Merid. 2: 213. 1830.

Figuras 36; Arbo (2005: 42A-T); Rocha \& Moreira (2014: fotos 58-60).

Arbustos 0,5-1 m alt.; caules tomentosos, tricomas tectores simples, bífidos a estrelados. Estípulas 2, 2-4 $\mathrm{mm}$ compr. Folhas com pecíolo 2-5 $\mathrm{mm}$ compr.; nectários 1-3 pares, 0,7-1 $\mathrm{mm}$ diâm., em todas as folhas; lâmina 2-7 × 1,7-4 cm, cartácea, discolor, elíptica, elíptico-ovada a largo-obovada, base atenuada a cuneada, ápice obtuso ou agudo, margens duplamente serreadas a crenadas, revolutas; face adaxial vilosa, nervuras fortemente impressas, bulada, face abaxial tomentoso-velutina, nervuras proeminentes. Inflorescências unifloras, agrupadas em racemos terminais abreviados; pedúnculo até ca. 0,5 $\mathrm{mm}$ compr., totalmente adnato ao pecíolo; brácteas ausentes; bractéolas 7-10 $\mathrm{mm}$ compr., lineartriangulares. Flores heterostilas, epífilas; pedicelo ausente. Cálice 7,5-12 $\mathrm{mm}$ compr., externamente 
viloso-hirsuto. Corola ca. 1,3 cm compr., amareloalaranjada. Filetes ca. $7 \mathrm{~mm}$ compr. em flores brevistilas, ca. $6 \mathrm{~mm}$ compr. em flores longistilas, esparso-piloso, base ca. $0,5 \mathrm{~mm}$ adnata ao tubo floral; anteras 1,3-1,5 mm compr., dorsifixas. Ovário ca. 1,5 $\mathrm{mm}$ compr., tomentoso-hirsuto; estiletes ca. 4,5 mm compr. em flores brevistilas, ca. $9 \mathrm{~mm}$ compr. em flores longistilas, ápice esparso-piloso; estigmas penicelados. Cápsulas ca. $6 \mathrm{~mm}$ diâm.; epicarpo liso, tomentoso apenas no ápice. Sementes 2,5-3 × 1-1,5 $\mathrm{mm}$, obovoides, ligeiramente curvas, tenuamente reticuladas; epiderme lisa; calaza proeminente, superfície plana.

Ocorre predominantemente no Distrito Federal e Goiás, havendo poucos registros para a Bahia e Minas Gerais (Arbo 2008, 2015). E2, E2/3: campos cerrados. Encontrada em áreas perturbadas, em margens de rodovias, em altitudes até $1000 \mathrm{~m}$. Apresenta flores e frutos no mês de março, e apenas flores em abril.

Material examinado - Barreiras, BR-020, $10 \mathrm{~km}$ a E da divisa Goias-Bahia, 1209'S, 4459'W, 1000 m, 10 mar. 1979 (fl., fr.), G. Hatschbach 42035 (C-foto, CTES, MBM); São Desidério, fazenda Sinué, 1259'31"S, 45²8' $18^{\prime \prime} \mathrm{W}, 1$ abr. 2011 (fl.), E.P. Queiroz 4816 (HRB).

Material adicional examinado - BRASIL. Distrito Federal: BR-020, 18 km S de Formosa, 15²46'S, 4755'W, 17 mar. 1982 (fl., fr.), G. Hatschbach 44772 (CTES, MBM).

Pode ser reconhecida pelas folhas grandes, discolores, com face adaxial bulada, inflorescências congestas, portando flores de corola amareloalaranjada, além dos nectários grandes, enegrecidos, principalmente nas folhas jovens. Turnera lamiifolia é similar a $T$. discolor Urb., a qual se diferencia pelas folhas geralmente menores e indumento composto apenas por tricomas simples.

2.24. Turnera leptosperma Urb., Repert. Spec. Nov. Regni Veg. 4: 135. 1907.

Figuras 36; Arbo (2005: fig. 31A-F); Rocha \& Moreira (2014: fotos 61 e 62).

Arbustos ou subarbustos 20-80 cm alt.; caules estrigosos a hirsutos, tricomas tectores simples e glandulares microcapitados. Estípulas 2, rudimentares. Folhas com pecíolo 2-6 mm compr.; nectários 1 ou 2 pares, 0,7-1,5 mm diâm.; lâmina 0,8-3,0 × 0,3-1,8 cm, cartácea, discolor, elíptica, ovada a obovada, base atenuada ou cuneada, ápice agudo a obtuso, margens revolutas, serreado-crenadas, $1 / 3$ proximal inteiro; face adaxial estrigosa ou hirsuta, nervuras impressas, face abaxial tomentosa, nervuras proeminentes. Inflorescências unifloras, solitárias ou agrupadas no ápice dos ramos; pedúnculo 2-4 mm compr., 1-3 $\mathrm{mm}$ adnato ao pecíolo; brácteas ausentes; bractéolas 4-10 $\mathrm{mm}$ compr., linear-triangulares. Flores heterostilas, epífilas; pedicelo ausente. Cálice 8,5-16 mm compr., externamente estrigoso. Corola $1-1,8 \mathrm{~cm}$ compr., creme. Filetes 5-6,5 mm compr. em flores brevistilas, 3-4,5 mm compr. em flores longistilas, glabros, margens 1-2 mm adnatas a unha das pétalas, formando sacos nectaríferos; anteras 1,7-3 mm compr., basifixas. Ovário 1,3-2 mm compr., tomentoso-hirsuto; estiletes 2,5-3 $\mathrm{mm}$ compr. em flores brevistilas, 5-8 $\mathrm{mm}$ compr. em flores longistilas, denso-pilosos; estigmas penicelados. Cápsulas 3,5-6 $\mathrm{mm}$ diâm.; epicarpo granuloso, denso-hirsuto. Sementes $2-3,8 \times 0,7-1,3$ $\mathrm{mm}$, estreito-oblongas, ligeiramente curvas, tenuamente reticuladas; epiderme lisa; calaza proeminente, superfície côncava, umbilicada.

Rara, endêmica da região central da Bahia (Arbo 2005; Arbo \& Giulietti 2009). C5, C6, D5, D6, E5, F5, G5: caatingas, cerrados, campos rupestres e campos gerais. Habita áreas abertas e perturbadas, como margens de trilhas e encostas. Cresce em substratos arenosos e rochosos, em altitudes de 500-2000 m. Apresenta flores e frutos de janeiro a maio, e agosto a novembro.

Material selecionado - Bom Jesus da Lapa, estrada em direção a Macaúbas, entre os distritos de São José e Laranjeiras, $13^{\circ} 18^{\prime} 35^{\prime \prime S}, 42^{\circ} 54^{\prime} 43^{\prime \prime W}, 821$ m, 12 jan. 2008 (fl., fr.), U.C.S. Silva et al. 18 (HUEFS); Boquira, Serra Geral, Serra do Brejo Grande, $12^{\circ} 49^{\prime} \mathrm{S}, 42^{\circ} 43^{\prime} \mathrm{W}, 11$ mar. 1998 (fl., fr.), G. Hatschbach et al. 67611 (CTES, MBM); Caetité, estrada saindo de Brejinho das Ametistas, $14^{\circ} 06^{\prime} \mathrm{S}, 42^{\circ} 47^{\prime} \mathrm{W}, 27$ abr. 2013 (fl., fr.), L. Rocha \& P. Gomes 429 (CTES, HUEFS, RB); Delfino, Serra do Curral Feio, $22 \mathrm{~km} \mathrm{NW} \mathrm{de}$ Lagoinha, na estrada para Minas do Mimoso, $10^{\circ} 24^{\prime} \mathrm{S}, 41^{\circ} 17^{\prime} \mathrm{W}, 980$ m, 6 mar. 1974 (fl., fr.), R.M. Harley et al. 16814 (CEPEC, CTES, IPA, K-foto, MBM, NY-foto, RB, U-foto, UEC, US-foto); Gentio do Ouro, "Serra do S. Inácio", fev. 1907 (fl., fr.), Ule E. 7512 (holótipo F [foto 13586], isótipos HBG-foto, K-foto); ib., rodovia

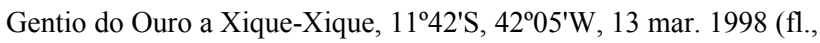
fr.), G. Hatschbach et al. 67728 (CTES, MBM); Macaúbas, Poço da Anta, $13^{\circ} 01^{\prime} \mathrm{S}, 42^{\circ} 41^{\prime} \mathrm{W}, 26$ nov. 2004 (fl., fr.), G. Hatschbach et al. 78586 (CTES, MBM); Morro do Chapéu, BA-052, a $22 \mathrm{~km}$ da cidade, $11^{\circ} 29^{\prime} 25^{\prime \prime S}, 41^{\circ} 20^{\prime} 17^{\prime \prime} \mathrm{W}, 890 \mathrm{~m}, 20$ jan. 2009 (fl., fr.), F.S. Gomes et al. 148 (ALCB); Oliveira dos Brejinhos, estrada Canabrava-Chapadão de Cima, próximo ao alto da Serra Geral, $12^{\circ} 19^{\prime} \mathrm{S}, 42^{\circ} 53^{\prime} \mathrm{W}, 16$ mar. 1998 (fl., fr.), G. Hatschbach et al. 67798 (CEPEC, CTES, MBM); Umburanas, Serra do Curral Frio, fazenda Licuri, $10^{\circ} 24^{\prime} 13^{\prime \prime S}, 41^{\circ} 18^{\prime} 42^{\prime \prime} \mathrm{W}, 908$ m, 28 maio 2010 (est.), L.P. Queiroz et al. 14380 (HUEFS); Xique-Xique, estrada para Barra, ca. $21 \mathrm{~km}$ da cidade, 104'S, 4243'W, 28 abr. 1999 (fl., fr.), A.M. Amorim et al. 3028 (CEPEC).

Pode ser reconhecida pelas folhas discolores, com face abaxial tomentosa, cinérea quando seca, além das flores com pétalas amarelas e estrias marromavermelhadas e sementes com calaza côncava e umbilicada. As flores foram encontradas abertas até 13:00 hs. Turnera leptosperma se assemelha a $T$. simulans, a qual se diferencia pelas folhas geralmente menores, serrilhadas com face abaxial estrigosa a esparso-estrigosa e flores de corola totalmente amarela.

2.25. Turnera luetzelburgii Sleumer, Notizbl. Bot. Gart. Berlin. 12: 70. 1934.

Figuras 13C e 37; Arbo (2008: figs 49A-L e 47A-K); Rocha \& Moreira (2014: fotos 63-67).

Subarbustos ou arbustos $0,1-1 \mathrm{~mm}$ alt.; caules esparso-estrigosos a vilosos, tricomas tectores simples 
e glandulares microcapitados. Estípulas 2, rudimentares. Folhas com pecíolo 1-5 $\mathrm{mm}$ compr.; nectários 2, 0,7-1,5 $\mathrm{mm}$ diâm., em todas as folhas; lâmina $0,5-4,3 \times 0,2-0,7 \mathrm{~cm}$, cartácea, discolor, fortemente recurvada ou aplanada, ovada, oblonga, elíptica a obovada, base atenuada, ápice agudo, margens denteadas a profundamente laciniadas, fortemente revolutas; face adaxial esparso-estrigosa, nervuras impressas, face abaxial quase glabra a densamente hirsuta, nervuras proeminentes. Inflorescências unifloras, solitárias ou agrupadas no ápice dos ramos; pedúnculo 3-7 $\mathrm{mm}$ compr., totalmente adnato ao pecíolo; brácteas ausentes; bractéolas $2,5-5 \mathrm{~mm}$ compr., linear-triangulares. Flores heterostilas, epífilas; pedicelo ausente. Cálice 6-12 $\mathrm{mm}$ compr., externamente estrigoso. Corola 8-18 mm compr., totalmente amarela ou com base das pétalas vinácea. Filetes ca. $8 \mathrm{~mm}$ compr. em flores brevistilas, ca. $4,5 \mathrm{~mm}$ compr. em flores longistilas, glabros, base $0,5-0,8 \mathrm{~mm}$ adnata ao tubo floral; anteras $0,8-1,7 \mathrm{~mm}$ compr., dorsifixas. Ovário 1-1,5 mm compr., tomentoso-hirsuto; estiletes 3,5-4,5 mm compr. em flores brevistilas, $6-9,5 \mathrm{~mm}$ compr. em flores longistilas, esparso-pilosos, estigmas penicelados. Cápsulas 2-4 $\mathrm{mm}$ diâm.; epicarpo liso, pubescente. Sementes 1,8-2,7 × 1-1,5 mm, obovoides, curvas, reticuladas; epiderme lisa; calaza cônica, superfície plana.

Ocorre em Minas Gerais e região central da Chapada Diamantina, na Bahia. D6, F4, F6, G5: cerrados e campos rupestres. Habita áreas abertas, em margens de trilhas e rodovias. Cresce em substratos arenosos e rochosos, em altitudes de $890-1850 \mathrm{~m}$. Apresenta flores e frutos durante o ano todo.

Material selecionado - Abaíra, Catolés de Cima-Bem Querer,

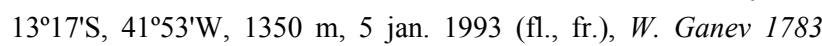
(CTES, HUEFS, SPF); Barra da Estiva, torre da Telebahia,

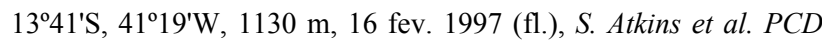
5754 (ALCB, CEPEC, HUEFS); Caetité, 12-20 km da cidade em direção a Brejinho das Ametistas, 1100-1200 m, 14 06'10"S$14^{\circ} 11^{\prime} 19^{\prime \prime} \mathrm{S}, 42^{\circ} 30^{\prime} 31^{\prime \prime W}-42^{\circ} 29^{\prime} 48^{\prime \prime} \mathrm{W}, 8$ mar. 1994, V.C. Souza et al. 5374 ([var. dubia] holótipo ESA, isótipos CTES, K-foto, SPF); Ibicoara, estrada entre Brejo de Cima e a rodovia Mucugê-Barra da

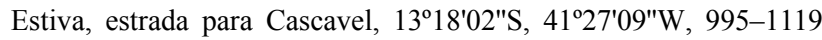
m, 5 fev. 2003 (fl.), F. França et al. 4323 (HUEFS); Ituaçu, estrada a $8 \mathrm{~km}$ de Barra da Estiva, Morro do Ouro, $13^{\circ} 48^{\prime} \mathrm{S}, 41^{\circ} 17^{\prime} \mathrm{W}, 17 \mathrm{jul}$. 1981 (fl.), A.M. Giulietti et al. CFCR 1286 (SPF); Licínio de Almeida, trilha para o Cachoeirão, 14%1'51"S, 42³3'21"W, 1112 m, 6 abr. 2013 (fl., fr.), L. Rocha et al. 406 (ALCB, HUEFS);

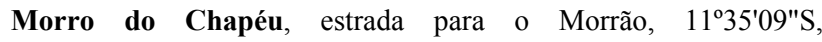

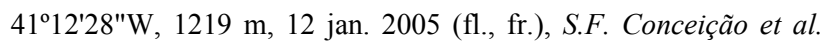

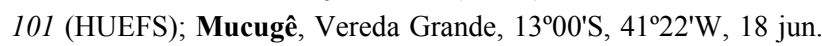
1984 (fl., fr.), G. Hatschbach \& R. Kummrow 48041 (CEPEC, CTES, MBM); Piatã, quebrada da Serra do Atalho, $13^{\circ} 13^{\prime} \mathrm{S}$, 4140'W, 1600-1700 m, 26 dez. 1992 (fl., fr.), R.M. Harley et al. 50418 (SPF); Paratinga, estrada Chapadão de Cima-São Bento, $12^{\circ} 41^{\prime} \mathrm{S}, 43^{\circ} 11^{\prime} \mathrm{W}, 16$ mar. 1998 (fl.), G. Hatschbach et al. 67838 (CTES, MBM); Rio de Contas, trilha de acesso ao Pico das Almas,

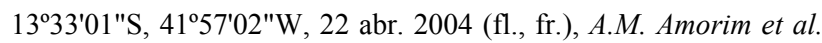
3998 (CEPEC, SP).
Pode ser reconhecida pelas folhas pinatifidas, com margens denteadas a profundamente laciniadas, fortemente revolutas, e flores de corola totalmente amarela ou com base das pétalas vinácea, além das sementes com calaza cônica. A face abaxial das folhas às vezes se torna cinérea quando seca. As flores foram encontradas abertas até 14:00 hs, visitadas por besouros e formigas.

Arbo (2008) considerou duas variedades para esta espécie: $T$. luetzelburgii var. luetzelburgii e $T$. luetzelburgii var. dubia Arbo, ambas ocorrem na Bahia. A variedade típica apresenta folhas geralmente pequenas, $0,5-1,2(-2) \times 0,2-1,6 \mathrm{~cm}$, ovadas, recurvadas, profundamente laciniadas; enquanto que $T$. luetzelburgii var. dubia apresenta folhas geralmente maiores, 1,7-4,3 $\times \quad 0,5-2 \mathrm{~cm}$, elípticas, estreito-ovadas a obovadas, aplanadas, denteadas. O exemplar Arbo 7456 apresenta características intermediárias às duas variedades, com folhas denteadas a profundamente laciniadas.

\subsection{Turnera maracasana Arbo, Bonplandia 10(1-4):}

\section{2000.}

Figuras 13D-G e 37; Arbo (2000: fig. 9A-H).

Arbustos 0,3-1 m alt.; caules denso a esparsoestrigosos, tricomas tectores simples e glandulares microcapitados e claviformes. Estípulas 3-4-sectadas, 2-9 $\mathrm{mm}$ compr. Folhas às vezes em braquiblastos terminais; pecíolo 1,5-5 $\mathrm{mm}$ compr.; nectários até 2 pares, 0,2-0,3 mm diâm.; lâmina $2-10 \times 1,5-3,8 \mathrm{~cm}$, papirácea, discolor, elíptica a obovada, base atenuada, ápice agudo ou acuminado, margens serrilhadas, ligeiramente revolutas; face adaxial glabra a esparsoestrigosa, nervuras ligeiramente impressas; face abaxial estrigosa, nervuras proeminentes e avermelhadas. Inflorescências em racemos terminais, abreviados, capituliformes; pedúnculo ca. $2 \mathrm{~mm}$ compr., livre do pecíolo; brácteas 5-10 × 1-3 mm, linear-lanceoladas; nectários ausentes; bractéolas $2,5,5-12 \mathrm{~mm}$, linearlanceoladas. Flores heterostilas; pedicelo ausente. Cálice 7,5-10 mm compr., externamente piloso. Corola 1-1,3 cm compr., branca, base das pétalas amarela; unha com apêndice $0,4-0,7 \mathrm{~mm}$ compr., cilíndrico, piloso. Filetes ca. $6 \mathrm{~mm}$ compr. em flores brevistilas, 4-5 mm compr. em flores longistilas, esparso-pilosos, base ca. $0,7 \mathrm{~mm}$ adnata ao tubo floral; anteras $1-1,5$ $\mathrm{mm}$ compr., dorsifixas. Ovário ca. $2 \mathrm{~mm}$ compr., ápice denso-piloso; estiletes ca. $2 \mathrm{~mm}$ compr. em flores brevistilas, 4,8-6,5 $\mathrm{mm}$ compr. em flores longistilas, porção mediana denso-pilosa; estigmas lobados. Cápsulas 3-5 $\mathrm{mm}$ diâm.; epicarpo tenuamente verrucoso, ápice denso-piloso. Sementes $2-3 \times$ ca. 1,5 $\mathrm{mm}$, largo-obovoides, ligeiramente curvas, reticuladas; epiderme lisa; calaza proeminente, superfície côncava.

Rara, endêmica do estado da Bahia (Arbo 2000; Arbo \& Giulietti 2009). E8, F7, F8: cerrados, restingas e matas de cipó. Habita o interior da mata ou locais abertos, em margens de rodovias, em altitudes até ca. $900 \mathrm{~m}$. Cresce em substratos areno-argilosos. Apresenta flores e frutos nos meses de abril, maio, agosto e dezembro. 


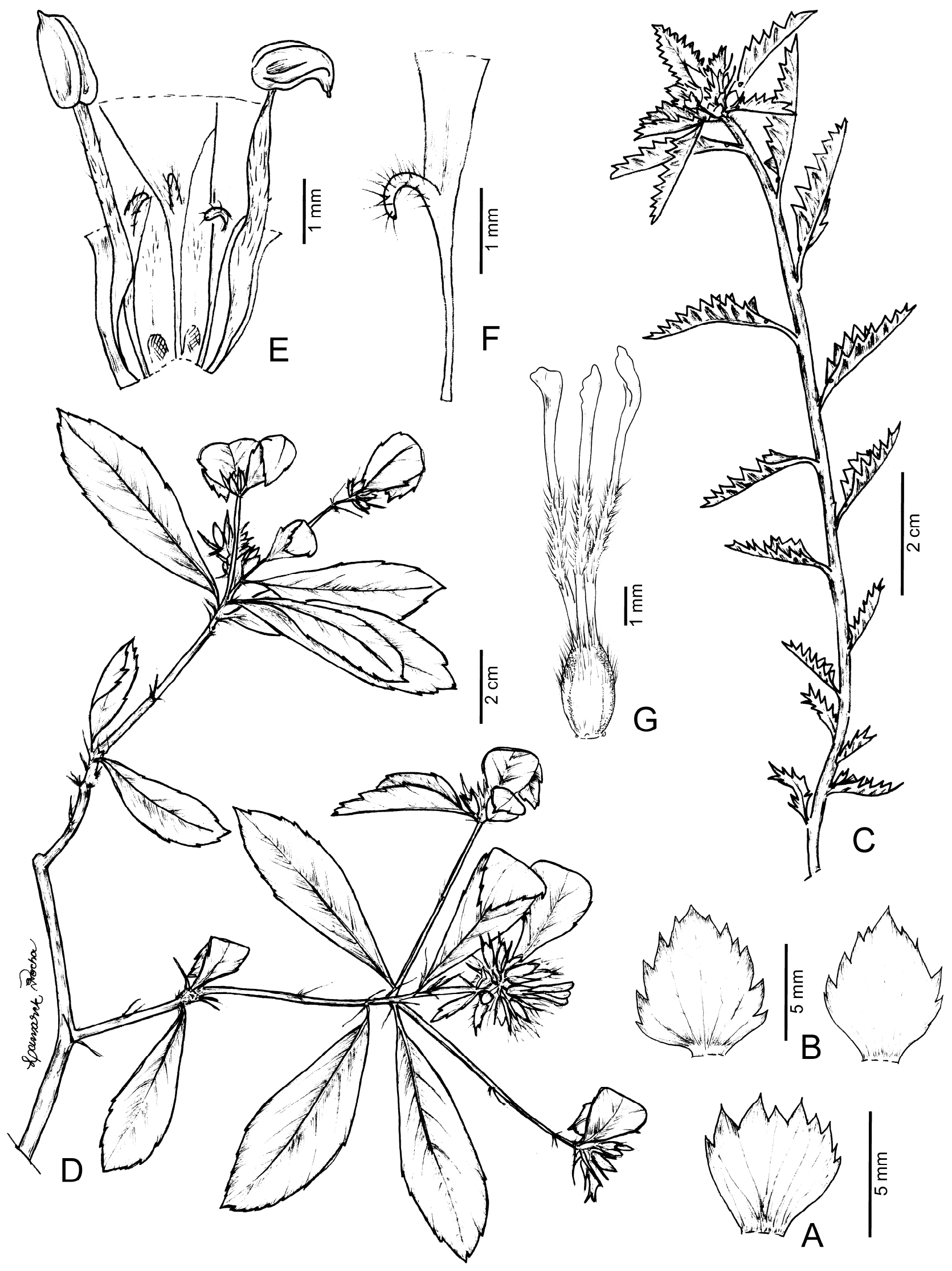

Figura 13. A, B. Turnera involucrata: A- bráctea (face adaxial); B- bractéolas (face adaxial) (Rocha 391). C. T. luetzelburgii var. dubia: ramo reprodutivo (Harley 15524). D-G. T. maracasana: D- ramo reprodutivo; E- flor dissecada evidenciando parte do androceu (flor brevistila); F- unha da pétala com apêndice; G- gineceu (Melo 2851). 
Material selecionado - Brejões, fazenda Lagoa do Morro, $13^{\circ} 07^{\prime} 14^{\prime \prime} \mathrm{S}, 39^{\circ} 53^{\prime} 03^{\prime \prime W}, 844 \mathrm{~m}, 17$ nov. 2007 (fl., fr.), F.M. Ferreira et al. 1840 (CEPEC); Jaguaquara, estrada para Itiruçu, ca. $6 \mathrm{~km}$ da BR-116, área do EBDA, 13³1'36"S, 4006'50"W, $730 \mathrm{~m}$, 27 ago. 1999 (fl., fr.), E. Melo et al. 2851 (CTES, HUEFS, RB); Lajedo do Tabocal, ca. $7 \mathrm{~km} \mathrm{~W}$ da sede, estrada para Maracás, entre as fazendas de Sinho e a de Alírio, $13^{\circ} 28^{\prime} 57^{\prime \prime} \mathrm{S}, 40^{\circ} 16^{\prime} 52^{\prime \prime} \mathrm{W}$ 845 m, 5 dez. 1999 (fl., fr.), E. Melo \& F. França 3210 (CTES, HUEFS); Maracás, BA-250, Fazenda dos Pássaros, $24 \mathrm{Km}$ a E da cidade, $13^{\circ} 28^{\prime} \mathrm{S}, 40^{\circ} 13^{\prime} \mathrm{W}, 900 \mathrm{~m}, 4$ maio 1979 (fl., fr.), S.A. Mori \& T.S. Santos 11774 (holótipo CEPEC, isótipos CTES, RB); ib., 17,9 $\mathrm{km}$ antes do trevo de Maracás, ramal à direita da BA-026, $13^{\circ} 28^{\prime} 45^{\prime \prime} \mathrm{S}, 40^{\circ} 16^{\prime} 55^{\prime \prime} \mathrm{W}, 861$ m, 3 nov. 2007 (fl., fr.), F.M. Ferreira et al. 1721 (CEPEC, RB); Santa Teresinha, Serra da Jiboia, 1251'09"S, 39²8'34"W, 800 m, 24 ago. 1996 (fl., fr.), C.A. Costa et al. 4 (CTES, HUEFS).

Pode ser reconhecida pelas estípulas grandes, 3-4sectadas, inflorescências em racemos terminais, capituliformes, portando flores de corola branca com base das pétalas amarela, unha com apêndice cilíndrico e estiletes denso-pilosos somente na porção mediana. Turnera maracasana se assemelha a $T$. princeps Arbo e T. hatschbachii Arbo, mas estas duas não ocorrem na Bahia. A primeira é endêmica de Minas Gerais e diferencia-se pelo indumento foliar mais denso, 2-6 pares de nectários e flores geralmente menores; a segunda é endêmica do Espírito Santo e diferencia-se pelas folhas lanceoladas, com 2-4 pares de nectários e flores menores.

2.27. Turnera marmorata Urb., Bot. Jahrb. Syst. 25 (Beibl. 60): 9. 1898.

Figuras 14A-B e 38; Arbo (2000: fig. 10A-J); Rocha \& Moreira (2014: fotos 68-71).

Subarbustos ou arbustos 0,2-3 m alt.; caules esparso-estrigosos, tricomas tectores simples. Estípulas 2, 0,5-1 mm compr. Folhas às vezes em braquiblastos terminais; pecíolo $0,5-3,5 \mathrm{~cm}$ compr.; nectários 1 ou 2 pares, 0,9-1,2 mm diâm.; lâmina 13-22,5 × 2-5,5 cm, coriácea, discolor, elíptico-obovada a lanceolada, base atenuada, ápice agudo a acuminado, margens inteiras a serrilhadas, planas; face adaxial glabra, nervuras impressas, face abaxial glabra, nervuras proeminentes. Inflorescências em racemos terminais, abreviados, capituliformes, bracteosos; pedúnculo 1-2,2 $\mathrm{mm}$ compr., adnato ao pecíolo, às vezes porção apical livre; brácteas $6-27 \times 0,8-5 \mathrm{~mm}$, linear-lanceoladas, 1-1,5 $\mathrm{mm}$ diâm.; bractéolas 5-8 mm compr., linearlanceoladas. Flores heterostilas, epífilas; pedicelo ausente. Cálice 1-1,1 cm compr., externamente estrigoso. Corola 1,1-1,3 mm compr., amarela. Filetes 6-7 mm compr. em flores brevistilas, 4-4,5 $\mathrm{mm}$ compr. em flores longistilas, glabros, base $0,8-1 \mathrm{~mm}$ adnata ao tubo floral; anteras 1,7-3,1 mm compr., dorsifixas. Ovário 2,8-3 mm compr., esparso-hirsuto; estiletes 3-3,5 $\mathrm{mm}$ compr. em flores brevistilas, ca. 5 mm compr. em flores longistilas, tomentosos; estigmas penicelados. Cápsulas 5-6 $\mathrm{mm}$ diâm.; epicarpo granuloso, estrigoso. Sementes $3,9-4,3 \times$ ca. $2 \mathrm{~mm}$, largo-obovadas, ligeiramente curvas, estriadoreticuladas; epiderme papilosa; calaza proeminente, superfície côncava.

Rara, endêmica da região sul da Bahia (Arbo 2000; Arbo \& Giulietti 2009). F8, G8: restingas e capoeiras. Habita áreas fechadas, por vezes inundadas ou perturbadas, como margens de trilhas. Cresce em substratos arenosos. Apresenta flores e frutos de setembro a maio.

Material selecionado - Itacaré, ca. 2,5 km da cidade, estrada para Maraú, $14^{\circ} 16^{\prime} \mathrm{S}, 38^{\circ} 59^{\prime} \mathrm{W}, 2 \mathrm{dez} .2007$ (fr.), S.C. Santana et al. 1298 (CEPEC); Ituberá, mata de Buruganga, $13^{\circ} 43^{\prime} \mathrm{S}, 39^{\circ} 08^{\prime} \mathrm{W}, 15$ set. 2006 (fl., fr.), M.L. Guedes et al. 12632 (ALCB, MBM); Maraú, estrada Itacaré-Maraú, $14^{\circ} 13^{\prime} 14^{\prime \prime} \mathrm{S}, 39^{\circ} 01^{\prime} 05^{\prime \prime} \mathrm{W}, 25 \mathrm{~m}, 29$ dez. 2005 (fl.), P.D. Carvalho et al. 252 (CTES, HUEFS); Nilo Peçanha, 5,8 km na estrada para Cairu, entrada para Turrinha ca. 1

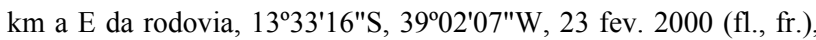
J.G. Jardim et al. 2793 (ALCB, CEPEC, CTES, HUEFS, NY-foto, RB, SPF); Valença, fazenda Bela Vista, $13^{\circ} 15^{\prime} 24^{\prime \prime} \mathrm{S}, 39^{\circ} 01^{\prime} 12^{\prime \prime} \mathrm{W}, 1$ maio 2012 (fl., fr.), E. Matos 3472 (HUEFS).

Pode ser reconhecida pelo porte arbustivo ou subarbustivo, com folhas grandes, glabras, às vezes dispostas em braquiblastos, com cicatrizes foliares salientes, além das inflorescências em racemos terminais, capituliformes, bracteosos, com flores de corola amarela. Trata-se da única espécie do gênero com tricomas no arilo. Sua morfologia, muito distinta das demais espécies de Turnera, faz com que se assemelhe a espécies de Rutaceae, Violaceae e Solanaceae, das quais pode ser distinta pela presença de nectários extraflorais basilaminares e sementes ariladas. Turnera marmorata é similar a T. glaziovii Urb., que não ocorre no Nordeste e se diferencia pelas flores solitárias, axilares, geralmente maiores. O exemplar de Santos 229 é descrito como "árvore de 6 metros", uma forma incomum nesta espécie.

2.28. Turnera melochioides Cambess. in Saint Hilaire, Jussieu \& Cambessedes, Fl. Bras. Merid. 2: 159 (219). 1883.

Figuras 38; Arbo (2008: fig. 53-54); Rocha \& Moreira (2014: fotos 72-78).

Subarbustos ou ervas $0,6-1 \mathrm{~m}$ alt.; caules densopilosos, vilosos ou hirsutos, tricomas tectores simples e glandulares capitado-estipitados. Estípulas rudimentares. Folhas com pecíolo 0,5-10 mm compr.; nectários até 4, 0,5-1 mm diâm., em todas as folhas; lâmina 1-6 × 0,4-2,3 cm, papirácea a cartácea, concolor ou discolor, elíptica, lanceolada a estreito-ovada, raro obovada, base atenuada a cuneada, ápice agudo a obtuso, margens duplamente serreado-crenadas, às vezes serreadas, planas a revolutas; face adaxial estrigosa, vilosa ou esparso-pilosa, nervuras impressas, face abaxial esparso a denso-estrigosa, vilosa ou quase glabra, nervuras proeminentes. Inflorescências unifloras, solitárias a agrupadas em racemos terminais; pedúnculo 2-5 $\mathrm{mm}$ compr., $1-3 \mathrm{~mm}$ adnato ao pecíolo; folhas floríferas às vezes reduzidas, bractiformes; bractéolas 2-7 $\mathrm{mm}$ compr., linear-triangulares 


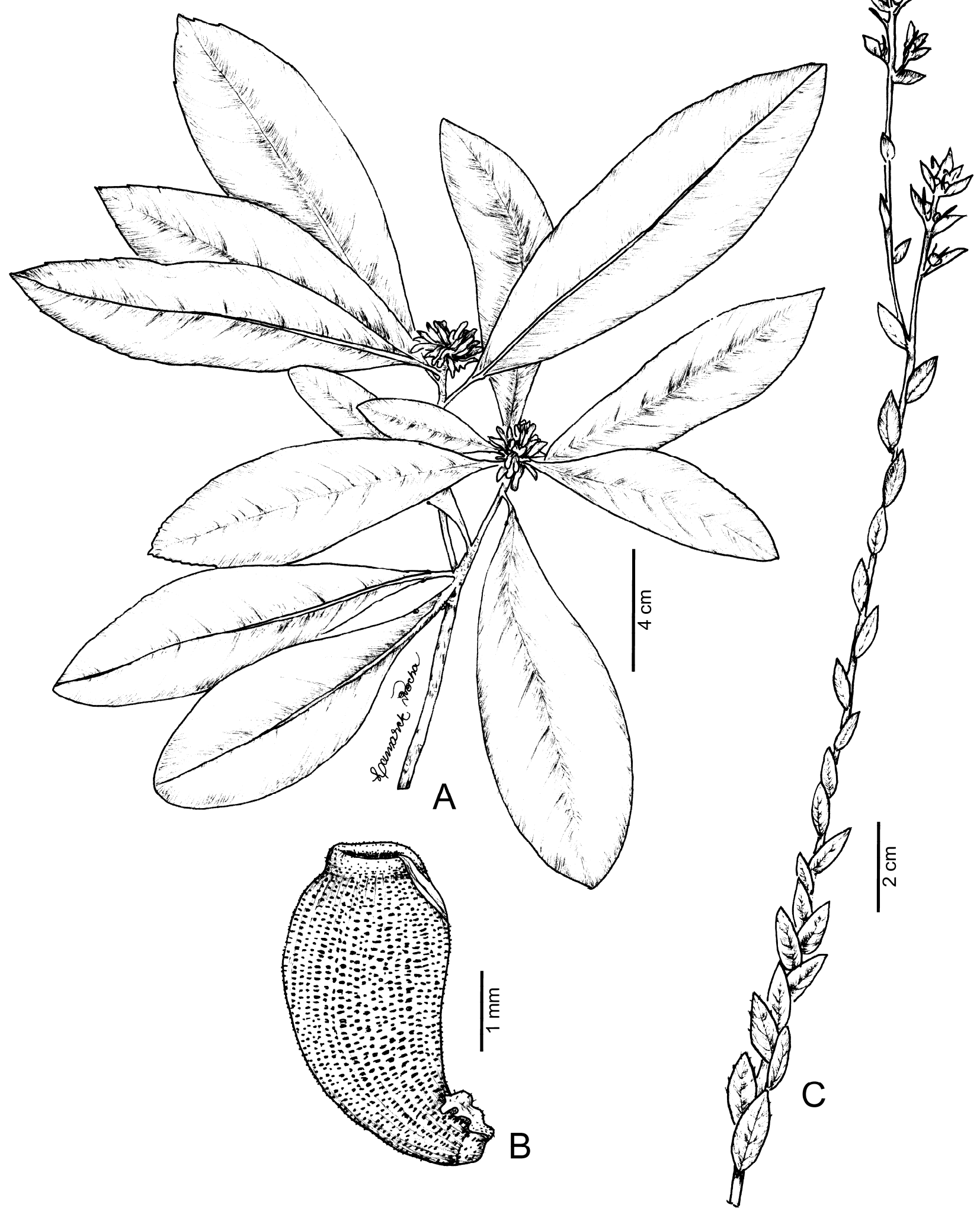

Figura 14. A-B. Turnera marmorata: ramo reprodutivo; B- semente (Jardim 2638). C. T. oblongifolia: ramo reprodutivo (Irwin 32871 ).

ou filiformes. Flores heterostilas, epífilas; pedicelo ausente. Cálice 4-9 mm compr., externamente estrigoso a hirsuto. Corola 4,3-13 $\mathrm{mm}$ compr., amarela, por vezes, com estrias avermelhadas no ápice e base das pétalas. Filetes 3,5-7 $\mathrm{mm}$ compr. em flores brevistilas, 3-4 $\mathrm{mm}$ compr. em flores longistilas, glabros, base ca. $0,3 \mathrm{~mm}$ adnata ao tubo floral; anteras 0,7-1 mm compr., dorsifixas. Ovário 1,3-1,5 mm 
compr., tomentoso a hirsuto; estiletes 2,5-4 $\mathrm{mm}$ compr. em flores brevistilas, 5-5,5 $\mathrm{mm}$ compr. em flores longistilas, ápice esparso-piloso; estigmas penicelados ou ramosos. Cápsulas 4-6 $\mathrm{mm}$ diâm.; epicarpo liso, denso-piloso. Sementes 1,7-2,5 × 0,8-1 mm, obovoides, curvas, reticuladas; epiderme com cera epicuticular baculiforme ou filiforme; calaza ligeiramente proeminente, superfície côncava.

Amplamente distribuída, do Brasil ao $\mathrm{NE}$ da Bolívia e NE do Paraguai (Arbo 2008). No Brasil, ocorre no Centro-Oeste (exceto Distrito Federal), Nordeste, Norte (exceto Roraima e Acre) e Sudeste (apenas Minas Gerais) (Arbo 2015). B5, C5, C6, C7, C8, C9, D2, D6, D7, E2, E3, E6, E9, F3, F4, F6, F7, G3, G4, G5: caatingas, cerrados, campos rupestres e áreas de transição cerrado/caatinga. Ocorre em diversos ambientes, sendo comum em terrenos baldios, áreas com a vegetação destruída, como margens de trilhas e rodovias, além de áreas urbanas. Cresce em substratos arenosos, argilosos ou rochosos, em altitudes até ca. $1100 \mathrm{~m}$. Apresenta flores e frutos durante o ano todo.

Material selecionado - Alagoinhas, UNEB campus II, $12^{\circ} 13^{\prime} \mathrm{S}, 38^{\circ} 41^{\prime} \mathrm{W}, 3$ ago. 2006 (fl., fr.), N.G. Jesus \& A.F. Santos 845 (HUEFS); Andaraí, ca. $1 \mathrm{~km}$ ao $\mathrm{S}$ do Distrito de Igatu, $12^{\circ} 53$ 'S, 41 ${ }^{\circ} 19^{\prime} \mathrm{W}, 15$ dez. 1999 (fl.), J.G. Jardim et al. 2317 (CEPEC); Angical, $60 \mathrm{~km} \mathrm{E}$ de Barreiras, 12 ${ }^{\circ} 03^{\prime} \mathrm{S}, 4^{\circ} 47^{\prime} \mathrm{W}, 18$ mar. 1982 (fl., fr.), A. Krapovickas et al. 37877 (CEN, CTES); Barra, Ibiraba, $10^{\circ} 47^{\prime} \mathrm{S}, 42^{\circ} 49^{\prime} \mathrm{W}, 27$ out. 2000 (fl., fr.), A.T.A. Rodarte 130 (CTES, $\mathrm{HRB})$; Barreiras, área do entorno de Cachoeira do Acaba Vidas, $11^{\circ} 53^{\prime} 09^{\prime \prime S}, 45^{\circ} 35^{\prime} 48^{\prime \prime W}, 1$ maio 2009 (fl., fr.), L.P. Queiroz et al. 14426 (HUEFS); Bom Jesus da Lapa, ca. $14 \mathrm{~km}$ ao $\mathrm{S}$ do entroncamento para Bom Jesus da Lapa, na estrada para Malhada, $13^{\circ} 24^{\prime} 14^{\prime} \mathrm{S}, 43^{\circ} 21^{\prime} 43^{\prime} \mathrm{W}, 11$ fev. 2000 (fl., fr.), L.P. Queiroz et al. 5863 (ALCB, CEPEC, CTES, HUEFS); Cachoeira, 12³7'S, $38^{\circ} 57^{\prime} \mathrm{W}$, fev. (fl., fr.), C.F.P. Martius s.n. (M 113148); Caetité, estrada Brejinho das Ametistas-Caetité, $14^{\circ} 06^{\prime} \mathrm{S}, 42^{\circ} 47^{\prime} \mathrm{W}, 22$ maio 1999 (fl., fr.), V.C. Souza et al. 23048 (CTES, ESA); Campo Formoso, COMISA (propriedade de Bayer) Cachoeira do Buraquinho, $10^{\circ} 05^{\prime} \mathrm{S}, 40^{\circ} 32^{\prime} \mathrm{W}, 21$ out. 1991 (fl., fr.), N.L. Menezes et al. 1281 (SPF); Canudos, Estação Biológica de Canudos, 0956'44"S, 38 58'53"W, 19 ago. 2004 (fl., fr.), F.H.M. Silva 509 (HUEFS); Carinhanha, rodovia para Cocos, $13 \mathrm{~km}$ a W da cidade,

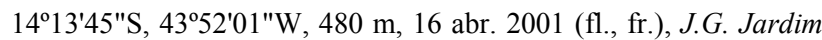
et al. 3553 (CEPEC, CTES, HUEFS); Casa Nova, Porto Casa Nova, rio São Francisco, 0909'S, 4058'W, 4 ago. 1939 (fl., fr.), P.T. Mendes s.n. (R 101568, SP 44263); Conceição do Jacuípe, 12²1'14"S, 3848'16"W, abr. 1974 (fl., fr.), G.C.P. Pinto 42269 (ALCB, CTES, IPA); Correntina, ca. $43 \mathrm{~km}$ a W de Santa Maria da

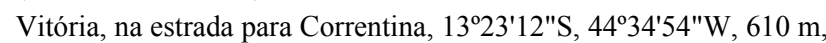
15 fev. 2000 (fl., fr.), L.P. Queiroz et al. 6041 (ALCB, CEPEC, CTES, HUEFS); Feira da Mata, Médio São Francisco, próximo ao rio Carinhanha, $14^{\circ} 14^{\prime} 05^{\prime \prime} \mathrm{S}, 4^{\circ} 11^{\prime} 52^{\prime \prime} \mathrm{W}, 28$ maio 2007 (fl., fr.), M.L. Guedes et al. 13583 (ALCB, HUEFS, BRBA); Feira de Santana, Estrada do Feijão, próximo às cinco cruzes, $12^{\circ} 16^{\prime} \mathrm{S}$, $38^{\circ} 58^{\prime} \mathrm{W}, 19$ maio. 2012 (fl., fl.), L. Rocha \& I. Souza 379 (HUEFS); Formosa do Rio Preto, $17 \mathrm{~km}$ da cidade, dentro da

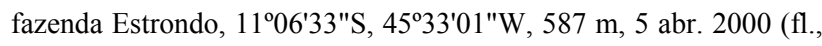
fr.), R.M. Harley et al. 53901 (ALCB, CTES, HUEFS); Ibotirama,
BR-242 Ibotirama-Barreiras Km 86, $12^{\circ} 07^{\prime} \mathrm{S}, 4^{\circ} 02^{\prime} \mathrm{W}, 830$ m, 7 jul. 1983 (fl., fr.), L. Coradin et al. 6628 (CEN, CTES); Igaporã, BR430 , próximo do trevo para Tanque Novo, $13^{\circ} 46^{\prime} \mathrm{S}, 42^{\circ} 42^{\prime} \mathrm{W}, 10$ mar. 1998 (fl., fr.), G. Hatschbach et al. 67584 (CTES, MBM); Inhambupe, $11^{\circ} 47^{\prime} \mathrm{S}, 38^{\circ} 21^{\prime} \mathrm{W}, 14$ fev. 1983 (fl.), G.C.P. Pinto 4383 (ALCB, CEPEC, HRB); Itaetê, antes 5-6 km da cidade, $13^{\circ} 00^{\prime} \mathrm{S}$, $41^{\circ} 37^{\prime} \mathrm{W}, 19$ jan. 2012 (fl., fl.), L. Rocha 361 (CTES, HUEFS); Jaborandi, 9,5 km da sede do município, 13⒊ $34^{\prime} 01^{\prime \prime S}, 44^{\circ} 30^{\prime} 33^{\prime \prime} \mathrm{W}$, 680 m, 19 abr. 2001 (fl., fr.), J.G. Jardim 3675 (CEPEC); Jacobina, Serra do Tombador, $19 \mathrm{~km}$ a NW da sede, BR-324, $11^{\circ} 05^{\prime} \mathrm{S}$, 4040'W, 17 jan. 1997 (fl., fr.), M.M. Arbo et al. 7396 (CEPEC, CTES, HUEFS); Jequié, $13^{\circ} 51^{\prime} \mathrm{S}, 40^{\circ} 05^{\prime} \mathrm{W}$, maio 1954 (fl., fr.), $J$. Vidal IV-1039 (R); Jeremoabo, Morro Santa, $10^{\circ} 06^{\prime} \mathrm{S}, 38^{\circ} 34^{\prime} \mathrm{W}, 10$ nov. 2010 (fl., fr.), E. Barbosa et al. 2835 (MBM); Lençóis, $12^{\circ} 34^{\prime}$ S, $41^{\circ} 23^{\prime} \mathrm{W}, 3$ abr. 1980 (fl., fr.), L. Noblick 1794 (ALCB, CTES, HUEFS); Licínio de Almeida, alto do Cachoeirão, 14²41'51"S, 42³3'21"W, 1112 m, 6 abr. 2013 (fl., fr.), L. Rocha et al. 403 (ALCB, CTES, HUEFS); Monte Santo, 10² $43^{\prime} \mathrm{S}, 39^{\circ} 33^{\prime} \mathrm{W}$, abr. (fl., fr.), C.F.P. Martius s.n. (M 113150); Morro do Chapéu, BA-052, $18 \mathrm{~km}$ de Morro do Chapéu, estrada para a Cachoeira do Ferro Doido, $11^{\circ} 55^{\prime} \mathrm{S}, 41^{\circ} 15^{\prime} \mathrm{W}, 28$ jan. 2013 (fl., fr.), L. Rocha \& B.S. Gregório 382 (CTES, HUEFS); Mucugê, a $5 \mathrm{~km}$ de Mucugê, $13^{\circ} 00^{\prime} \mathrm{S}, 41^{\circ} 37^{\prime} \mathrm{W}, 18$ jan. 2012 (fl., fl.), L. Rocha et al. 358 (CTES, HUEFS); Nova Redenção, povoado das Queimadas, 12²9'06"S, 41 04'15"W, 24 abr. 2010 (fl., fr.), P.G. Ribeiro 19 (HUEFS);

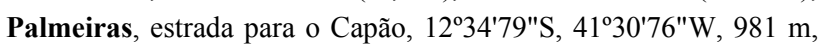
29 abr. 2012 (fl., fl.), L. Rocha \& I. Souza 370 (CTES, HUEFS, SPF); Piatã, área da sinclinal de Piatã, estrada para o povoado de

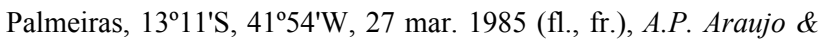
W.N. Fonseca 415 (RB); Pilão Arcado, Dourados, Lagoa do Jatobá, $10^{\circ} 00^{\prime} \mathrm{S}, 42^{\circ} 30^{\prime} \mathrm{W}, 12$ nov. 2009, A.P. Prata et al. 2146 (ASE); Riachão das Neves, BR-135, estrada Barreiras-Corrente, $11^{\circ} 44^{\prime} \mathrm{S}$, 4454'W, 1 abr. 1983 (fl., fr.), A. Krapovickas et al. 38713 (C-foto, CTES, F-foto, K-foto, MBM); Ribeira do Pombal, $10^{\circ} 50^{\prime} \mathrm{S}$, $38^{\circ} 32^{\prime} \mathrm{W}, 19$ maio 1981 (fl.), L.M.C. Gonçalves 83 (CEPEC, HRB, $\mathrm{RB}$ ); Rio de Contas, $8 \mathrm{~km}$ de Rio de Contas, na estrada para Mato Grosso, 1331'47"S, 41 ${ }^{\circ} 51^{\prime} 50^{\prime \prime W}, 17$ abr. 2009 (fl., fr.), R.M. Harley et al. 55940 (HUEFS); São Desidério, ca. $6 \mathrm{~km} \mathrm{~S}$ da Ilha do Vitor,

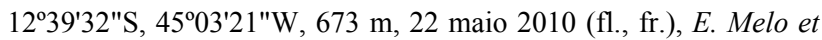
al. 8261 (HUEFS); Seabra, $12^{\circ} 25^{\prime} \mathrm{S}, 41^{\circ} 46^{\prime} \mathrm{W}, 23$ jun. 2000 (fl., fr.), L.F.G. Paschoaletti 7 (HUEFS); Tucano, Km 7-10 na estrada de Tucano para Ribeira do Pombal, 1057'S, 3847'W, 21 mar. 1992 (fl., fr.), A.M. Carvalho et al. 3895 (CTES, CEPEC, NY-foto); Umburanas, Serra do Curral Feio, Cachoeirinha, ca. $10 \mathrm{~km}$ a NW de Delfino, $10^{\circ} 21^{\prime} \mathrm{S}, 41^{\circ} 13^{\prime} \mathrm{W}, 11$ abr. 1999 (fl., fr.), L.P. Queiroz et al. 5378 (CTES, HUEFS); Utinga, 12 $01^{\prime} 09^{\prime \prime} \mathrm{S}, 41^{\circ} 01^{\prime} 31^{\prime \prime} \mathrm{W}, 600 \mathrm{~m}$, 1 mar. 2003 (fl., fr.), L.R. Senna et al. 110 (HUEFS).

Pode ser reconhecida pelas folhas duplamente serreado-crenadas, por vezes serreadas, flores pequenas, solitárias ou agrupadas em racemos terminais, corola amarela, por vezes com estrias avermelhadas na base e no ápice das pétalas. As flores foram encontradas abertas às 16:00, visitadas por besouros, além de diversas espécies de formigas. Turnera melochioides se assemelha a $T$. opifera e $T$. harleyi, sendo de difícil separação com base em material herborizado; a primeira se diferencia pelos ramos com indumento estrigoso, com tricomas adpressos, frutos e flores geralmente maiores, às vezes dispostas em racemos paniculiformes; a 
segunda se diferencia principalmente pelas folhas lineares, lanceoladas ou oblanceoladas com margens fortemente revolutas, geralmente com 3 ou 4 pares de dentes obtusos.

Turnera melochioides apresenta grande variação morfológica, de modo que Urban (1883) descreveu seis variedades a partir dos poucos exemplares então disponíveis. Com o incremento da amostragem, Arbo (2008) detectou sobreposições nos caracteres usados por Urban e considerou somente três das seis variedades, propondo uma nova. A autora registou três variedades para a Bahia: T. melochioides var. melochioides, T. melochioides var. arenaria Urb. e $T$. melochioides var. latifolia Urb. A variedade típica pode ser reconhecida pelas folhas cartáceas a coriáceas, elípticas, largo-elípticas, ovadas a raramente obovadas, castanho-escuras quando secas. Turnera melochioides var. arenaria e $T$. melochioides var. latifolia apresentam folhas papiráceas, verde-oliva pálido quando secas; a primeira exibe folhas estreito-elípticas, lineares, quase inteiras ou serrilhadas, enquanto a segunda possui folhas ovadas a ovado-lanceoladas, simples ou duplamente crenadas. A outra variedade, $T$. melochioies var. rugosa Arbo, ocorre apenas no estado de Goiás, e pode ser reconhecida principalmente pelas folhas coriáceas e epicarpo geralmente rugoso.

2.29. Turnera oblongifolia Cambess. in Saint-Hilaire, Jussieu \& Cambessedes, Fl. Bras. Merid. 2: 215. 1830 .

Figuras 14C e 39; Arbo (2008: fig. 57A-R); Rocha \& Moreira (2014: fotos 79-81).

Ervas ca. $40 \mathrm{~cm}$ alt.; caules esparso-estrigosos, tricomas tectores simples e microcapitados. Estípulas 2, rudimentares. Folhas com pecíolo até $4 \mathrm{~mm}$ compr.; nectários 2, 0,2-0,7 mm diâm., em todas as folhas; lâmina 9-20 × 2-4 mm, cartáceas a quase coriáceas, concolor, ovada a estreito-ovada, base atenuada, ápice agudo, margens serrilhadas, planas; as duas faces esparso-estrigosas, com nervuras proeminentes. Inflorescências unifloras, solitárias a reunidas em racemos terminais; pedúnculo 2-4 $\mathrm{mm}$ compr., totalmente adnato ao pecíolo; folhas floríferas às vezes reduzidas, bractiformes; bractéolas 3-4 mm compr., linear-triangulares. Flores heterostilas, epífilas; pedicelo ausente. Cálice 7-7,5 $\mathrm{mm}$ compr., externamente estrigoso. Corola ca. $1 \mathrm{~cm}$ compr., amarela, às vezes base das pétalas amarelo-escuro com estrias marrons. Filetes ca. $5 \mathrm{~mm}$ compr. em flores brevistilas, 3,5-6 mm compr. em flores longistilas, glabros, base ca. $0,3 \mathrm{~mm}$ adnata ao tubo floral; anteras $1-2 \mathrm{~mm}$ compr., dorsifixas. Ovário ca. $1 \mathrm{~mm}$ compr., tomentoso; estiletes ca. $3 \mathrm{~mm}$ compr. em flores brevistilas, 5-7 $\mathrm{mm}$ compr. em flores longistilas, glabros; estigmas penicelados. Cápsulas 4-5 mm diâm.; epicarpo liso, estrigoso. Sementes $2-2,3 \times$ ca. $1 \mathrm{~mm}$, obovoides, curvas, reticuladas; epiderme com cera epicuticular filiforme; calaza proeminente, superfície côncava.
Ocorre na Bahia, Goiás, Minas Gerais, Paraná e São Paulo (Arbo 2008, 2014). E2: cerrados. Foi encontrada em encostas rochosas, com flores e frutos nos meses de março e novembro.

Material examinado - Barra da Estiva, Serra de Sincorá, nov. (fl., fr.), C.F.P. Martius s.n. (M-foto); São Desidério, Roda Velha, Espigão Mestre, ca. $10 \mathrm{~km}$ ao $\mathrm{N}$ do rio Roda Velha, ca. $100 \mathrm{~km}$ a WSW de Barreiras, $12^{\circ} 42^{\prime} \mathrm{S}, 45^{\circ} 49^{\prime} \mathrm{W}, 800$ m, 9 mar. 1972 (fl., fr.), W.R. Anderson et al. 36891 (UB).

Material adicional examinado - BRASIL. Minas Gerais: Morro do Ferro, ca. $7 \mathrm{~km}$ da cidade em direção ao observatório, 2045'38"S, 4433'23"W, 15 jan. 1994 (fl., fr.), V.C. Souza et al. 5084 (CTES, ESA, HUEFS, SPF).

Pode ser reconhecida pelas folhas ovadas a estreitoovadas, esparso-estrigosas, com nervuras proeminentes nas duas faces e flores de corola amarela, com base das pétalas amarelo-escura e estrias marrons. Turnera oblongifolia se assemelha a $T$. hilaireana Urb., não ocorrente na Bahia e que se diferencia principalmente pelos caules com entrenós longos, folhas papiráceas, nectários grandes e cálice esparso-hirsuto.

2.30. Turnera opifera Mart., Reise Bras. 2: 552. 1828.

Figuras 39; Arbo (2008: fig. 57A-R); Rocha \& Moreira (2014: fotos 82-85).

Subarbustos ca. $50 \mathrm{~cm}$ alt.; caules densoestrigosos, tricomas tectores simples e glandulares microcapitados. Estípulas 2, rudimentares. Folhas com pecíolo 3-4 mm compr.; nectários 2, 0,5-1,2 $\mathrm{mm}$ diâm., em todas as folhas; lâmina $0,4-4(-9,5) \times 0,2-$ $1,4(-2,5) \mathrm{cm}$, cartácea, discolor, elíptica a elípticoobovada, base atenuada, ápice agudo, margens serrilhado-crenuladas, ligeiramente revolutas; face adaxial estrigosa, nervuras impressas, face abaxial denso-estrigosa, nervuras proeminentes. Inflorescências unifloras, solitárias a reunidas em racemos paniculiformes; pedúnculo 4-5 $\mathrm{mm}$ compr., totalmente adnato ao pecíolo; brácteas ausentes; bractéolas 3-5 mm compr., linear-triangulares. Flores heterostilas, epífilas; pedicelo ausente. Cálice 9-12 mm compr., externamente denso-estrigoso. Corola 1,3-2 cm compr., amarela. Filetes 7-9 mm compr. em flores brevistilas, 5-6 $\mathrm{mm}$ compr. em flores longistilas, glabros, base ca. $0,5 \mathrm{~mm}$ adnata ao tubo floral; anteras ca. $1 \mathrm{~mm}$ compr., dorsifixas. Ovário 1,5-2 mm compr., tomentoso; estiletes 4-5 $\mathrm{mm}$ compr. em flores brevistilas, 7-8 mm compr. em flores longistilas, ápice esparso-piloso; estigmas ramosos. Cápsulas 6-8 mm diâm; epicarpo liso, esparso-piloso. Sementes 2,5-3 × 1-1,3 mm, obovoides, curvas, reticuladas; epiderme com cera epicuticular filiforme; calaza proeminente, superfície côncava.

Ocorre na Bahia e Minas Gerais (Arbo 2015). H6: cerrados. Encontrada com flores e frutos no mês de janeiro.

Material examinado - Cândido Sales, BR-116, $3 \mathrm{~km}$ ao $\mathrm{S}$ da cidade, $15^{\circ} 05^{\prime} \mathrm{S}, 41^{\circ} 23^{\prime} \mathrm{W}, 19$ jan. 1984 (fl., fr.), G. Hatschbach 47352 (CEPEC, CTES, MBM). 
Material adicional examinado - BRASIL. Minas Gerais: Diamantina, 20-26 km a WSW da cidade, estrada para Conselheiro Mata, MG-220, 18¹7'S 4349'W, 1270-1300 m, 18 maio 1990 (fl., fr.), M.M. Arbo et al. 4408 (CTES, MBM, SPF); Grão Mogol, Ribeirão, 16³3'S, 4253'W, 11 jun. 1990 (fl., fr.), G. Hatschbach et al. 54194 (CTES, MBM); Salinas, estrada para Aeroporto a $2 \mathrm{~km}$ do entroncamento, 16 $11^{\prime} 46^{\prime \prime} \mathrm{S}, 42^{\circ} 20^{\prime} 18^{\prime \prime} \mathrm{W}, 704$ m, 7 abr. 2002 (fl., fr.), T. Ribeiro et al. 290 (HUEFS, IPA).

Pode ser reconhecida principalmente pelo indumento estrigoso, folhas serrilhado-crenuladas, elípticas a elíptico-obovadas, face abaxial castanhoescura, face abaxial castanho-pálida e flores geralmente grandes. Turnera opifera se assemelha a $T$. melochioides, principalmente T. melochioides var. melochioides, pois ambas apresentam coloração castanho-escura quando secas, estames glabros, estigmas com ápice esparso-piloso e epiderme das sementes com cera epicuticular filiforme. A inflorescência e a dimensão das pétalas são as principais características para a separação destas espécies: T. opifera apresenta flores geralmente grandes, dispostas em racemos paniculiformes, enquanto $T$. melochioides var. melochioides apresenta flores geralmente pequenas, em racemos terminais (Arbo 2008).

Apresenta floração rápida, em áreas queimadas recentemente, já podem ser encontrados rebrotos com cerca de $5 \mathrm{~cm}$ de altura floridos (Arbo 2008). Em Arbo 4408 , os rebrotos apresentam folhas pequenas, ovadoelípticas e flores isoladas ou agrupadas no ápice dos ramos, semelhante a Turnera hilaireana, a qual se diferencia pelas folhas patentes com nervuras proeminentes em ambas as faces.

\subsection{Turnera orientalis (Urb.) Arbo, Candollea 40:} 177. 1985.

Figuras 39; Arbo (2008: fig. 49H-M).

Subarbustos $0,2-1 \mathrm{~m}$ alt.; caules estrigosos a denso-estrigosos, tricomas tectores simples e glandulares microcapitados. Estípulas 2, rudimentares. Folhas com pecíolo 3-14 mm compr.; nectários 2, 11,5 mm diâm.; lâmina $1,4-7,7 \times 0,5-3 \mathrm{~cm}$, papirácea, ligeiramente discolor, ovada, estreito-ovada a elíptica, base cuneada, ápice agudo a obtuso, margens duplamente serreado-crenadas, planas; face adaxial estrigosa, nervuras impressas, face abaxial densopilosa, nervuras proeminentes. Inflorescências unifloras, solitárias a agrupadas no ápice dos ramos; pedúnculo 5-10 $\mathrm{mm}$ compr., totalmente adnato ao pecíolo; brácteas ausentes; bractéolas 5-10 $\mathrm{mm}$ compr., linear-triangulares. Flores homostilas, epífilas; pedicelo ausente. Cálice 1,2-1,8 cm compr., externamente denso-estrigoso. Corola $1,4-2 \mathrm{~cm}$ compr., amarela, base das pétalas amarelo-escura. Filetes 7,5-10 mm compr., glabros, margens ca. $2 \mathrm{~mm}$ adnatas a unha das pétalas, formando sacos nectaríferos; anteras 2,5-2,7 $\mathrm{mm}$ compr., basifixas. Ovário ca. $2 \mathrm{~mm}$ compr., tomentoso; estiletes ca. $9 \mathrm{~mm}$ compr., glabros; estigmas penicelados. Cápsulas 7-9 mm diâm.; epicarpo verrucoso, hirsuto. Sementes 2$2,5 \times 1-0,8 \mathrm{~mm}$, estreito-obovoides, ligeiramente curvas, reticuladas; epiderme lisa; calaza obtusa, superfície plana.

Distribui-se pelo sudoeste da Bolívia, região oriental do Paraguai e Noroeste da Argentina. No Brasil, ocorre no Centro-Oeste (Distrito Federal, Goiás e Mato Grosso do Sul), Nordeste (Bahia), Norte (Tocantins), Sudeste (Minas Gerais, Rio de Janeiro e São Paulo) e Sul (Paraná) (Arbo 2005, 2015). G8, H9, I8: caatingas e florestas ombrófilas. Foi encontrada em áreas de cultivo de cacau, pastagens e margens de rodovias. Apresenta flores e frutos nos meses de janeiro, março, maio e setembro.

Material selecionado - Belmonte, Belmonte-ramal Santa Maria Eterna, 1551'S, 38 52'W, 11 set. 1967 (fl., fr.), R.S. Pinheiro \& T.S. Santos 399 (CEPEC, CTES); Ilhéus, $30 \mathrm{~km}$ ao N de Ilhéus na estrada para Itacaré, $14^{\circ} 47^{\prime} \mathrm{S}, 39^{\circ} 02^{\prime} \mathrm{W}, 25$ jan. 2003 (fl., fr.), $C$. van den Berg 938 (HUEFS); Itabuna, rodovia para Ubaitaba, $14^{\circ} 47^{\prime} \mathrm{S}, 39^{\circ} 16^{\prime} \mathrm{W}, 19$ mar. 1971 (fl., fr.), R.S. Pinheiro 1178 (CEPEC); Itambé, estrada para Itapebi, $15^{\circ} 14^{\prime} \mathrm{S}, 40^{\circ} 37^{\prime} \mathrm{W}, 15$ maio 1970 (fl.), T.S. Santos 804 (CEPEC, CTES); Porto Seguro, Parque Nacional Monte Pascoal, área limite entre o PARNA e a Reserva Indígena Barra Velha da tribo Pataxó, $16^{\circ} 45^{\prime} \mathrm{S}, 39^{\circ} 06^{\prime} \mathrm{W}, 13$ set. 1998 (fl., fr.), A.M. Amorim et al. 2504 (CEPEC, CTES, SP).

Pode ser reconhecida pelas flores homostilas, de corola amarela, com base das pétalas amarelo-escura. $\mathrm{O}$ gineceu pode ser até $1,5 \mathrm{~mm}$ maior ou menor que o androceu. Turnera orientalis se assemelha a $T$. cuneiformis e T. scabra, sendo o material seco de difícil separação. A primeira se diferencia pelas pétalas amarelas, raro creme e base das pétalas castanhoescura; a segunda se diferencia principalmente pelas flores heterostilas e corola com estrias alaranjadas.

\subsection{Turnera paradoxa Arbo, Bonplandia 17(2): 43.} 2008.

Figuras 40; Arbo (2008: 60A-O).

Subarbusto ca. $10 \mathrm{~cm}$ alt.; caules denso-estrigosos, tricomas tectores simples. Estípulas rudimentares. Folhas com pecíolo 1-5 mm compr.; nectários até 2, ca. $2 \mathrm{~mm}$ diâm., em todas as folhas; lâmina 22-35 × 2,6-4 mm, papirácea, concolor, lanceolada ou estreitoelíptica a linear, base atenuada, ápice agudo, margens geralmente inteiras, raro serrilhadas, ligeiramente revolutas, face adaxial esparso-pilosa, nervuras impressas, face abaxial esparso-pilosa, nervuras proeminentes, ferrugíneas. Inflorescências unifloras, solitárias; pedúnculo 1,5-2 $\mathrm{mm}$ compr., totalmente adnato ao pecíolo; brácteas ausentes; bractéolas 3-6,5 $\mathrm{mm}$ compr., lineares. Flores provavelmente heterostilas, epífilas; pedicelo ausente. Cálice ca. $6 \mathrm{~mm}$ compr., externamente esparso-piloso. Corola ca. $5 \mathrm{~mm}$ compr., amarela. Filetes ca. $5 \mathrm{~mm}$ compr. em flores brevistilas, glabros, base brevemente adnata ao tubo floral; anteras ca. 0,7 mm compr., dorsifixas. Ovário ca. $0,8 \mathrm{~mm}$ compr., tomentoso; estiletes ca. $2,5 \mathrm{~mm}$ compr. em flores brevistilas, glabros, estigmas penicelados. Cápsulas ca. $3 \mathrm{~mm}$ diâm.; epicarpo liso, 
esparso-piloso. Sementes ca. 1,9 × $1 \mathrm{~mm}$, obovoides, curvas, reticuladas; epiderme papilosa; calaza proeminente, superfície côncava.

Conhecida somente pelo holótipo, encontrado no cerrado da região oeste do estado da Bahia, em altitude de 600 m. E2: Apresenta flores e frutos no mês de novembro.

Material examinado - São Desidério, Roda Velha, Espigão Mestre, vale do Rio das Ondas, ca. $25 \mathrm{~km}$ a W de Barreiras, $12^{\circ} 21^{\prime} \mathrm{S}$, $44^{\circ} 58^{\prime} \mathrm{W}, 600$ m, 3 mar. 1971 (fl., fr.), H.S. Irwin et al. $31354 b$ (holótipo NY-foto).

Reconhecida pelas folhas lanceoladas a estreitoelípticas, com nervuras ferrugíneas na face abaxial e sementes curvas, além dos caules com entrenós curtos e nectários marrons, maiores nas folhas floríferas. Turnera paradoxa assemelha-se a $T$. stenophylla, a qual se diferencia pelas folhas lanceoladas, face adaxial com nervuras castanho-avermelhadas, nas duas faces e frutos verrucosos. O holótipo foi coletado há mais de 40 anos, numa área atualmente bastante alterada pela expansão agrícola, comprometendo a manutenção de hábitats favoráveis para a espécie.

2.33. Turnera pumilea L., Syst. Nat. ed. 10, 2: 965. 1759.

Figuras 40; Arbo (2008: fig. 66 e 67); Rocha \& Moreira (2014: fotos 86-88).

Ervas a subarbustos $15-40 \mathrm{~cm}$ alt.; caules tomentosos a tomentoso-hirsutos, tricomas tectores simples, cinéreos. Estípulas 2, rudimentares. Folhas geralmente congestas em rosetas no ápice dos ramos; pecíolo 2-14 mm compr.; nectários até 2, 0,3-0,5 $\mathrm{mm}$ diâm., em todas as folhas; lâmina 1,2-4,5 × 0,4-1,7 $\mathrm{cm}$, papirácea, concolor, ovada, estreito-ovada a elíptica, base atenuada a cuneada, ápice agudo a obtuso, margens simples ou duplamente serreadas a serreado-crenadas, planas; face adaxial esparso-pilosa, nervuras impressas, face abaxial denso-hirsuta, nervuras proeminentes. Inflorescências unifloras, solitárias a congestas no ápice dos ramos; pedúnculo 3-6 mm compr., totalmente adnato ao pecíolo; brácteas ausentes; bractéolas 3-5 $\mathrm{mm}$ compr., lineartriangulares a lineares. Flores homostilas ou heterostilas, epífilas; pedicelo ausente. Cálice 8,5-11 $\mathrm{mm}$ compr., externamente glabro na base, lacínios hirsutos. Corola 1-1,2 cm compr., creme ou amarela, base das pétalas amarelo-alaranjada ou com estrias marrons. Filetes 4,3-8 mm compr., glabros, base ca. 2 $\mathrm{mm}$ adnata ao tubo floral; anteras $0,7-1,3 \mathrm{~mm}$ compr., dorsifixas. Ovário 1-1,5 $\mathrm{mm}$ compr., denso-hirsuto apenas no ápice; estiletes 3-7,9 mm compr., glabros; estigmas penicelados. Cápsulas 4-6 $\mathrm{mm}$ diâm.; epicarpo liso, denso-hirsuto apenas no ápice. Sementes 1,5-2 × 0,7-1 mm, lunadas, reticuladas; epiderme com cera epicuticular filiforme; calaza cônica, superfície plana.

Amplamente distribuída, desde o México e Ilhas do Caribe até o norte da Argentina. No Brasil, ocorre no Centro-Oeste (exceto Distrito Federal), Nordeste (exceto Alagoas), Norte (Pará, Roraima e Tocantins) e Sudeste (Minas Gerais e Rio de Janeiro) (Arbo 2008, 2015). B6, B7, C5, C7, D3, D6, D7, E4, E5, E8, F4, F5, G5, G6, G7, I8: caatingas e cerrados. Associa-se a diversos tipos de ambientes, sendo comum em áreas alteradas, como margens de trilhas e rodovias ou zonas urbanas. Cresce em substratos arenosos, argilosos ou rochosos, em altitudes até $900 \mathrm{~m}$. Floresce e frutifica durante o ano todo.

Material selecionado - Anagé, estrada para Vitória, ca. $5 \mathrm{~km}$

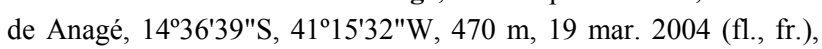
L.P. Queiroz et al. 9209 (CTES, HUEFS, MBM, RB, SPF); Bom Jesus da Lapa, 5-10 $\mathrm{km}$ da rodovia para Malhada, $13^{\circ} 25^{\prime} \mathrm{S}$, 43ํํ'W, 500 m, 5 abr. 1992 (fl., fr.), G. Hatschbach et al. 56602 (CTES, MBM); Brumado, $30 \mathrm{~km}$ a W de Brumado, estrada Caetité,

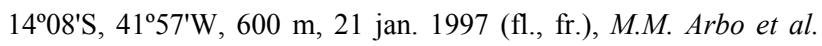
7625 (CEPEC, CTES); Caetité, Brejinho das Ametistas, 14 $15^{\prime} 22^{\prime \prime S}, 42^{\circ} 31^{\prime} 20^{\prime \prime} \mathrm{W}, 880$ m, 13 mar. 2002 (fl., fr.), N. Roque et al. 631 (HRB, HUEFS, IPA, SPF); Casa Nova, Caraíba dos Bragas, 0909'S, 4058'W, 10 fev. 1988 (fl., fr.), C.V. Moruz 154 (HRB); Feira de Santana, Campus da UEFS, $12^{\circ} 15^{\prime} \mathrm{S}, 38^{\circ} 58^{\prime} \mathrm{W}, 25$ maio 1983 (fl., fr.), L.R. Noblick 2678 (HUEFS, MBM); Filadélfia, BR407, 4-9 km ao N da cidade, estrada para Senhor do Bomfim, $10^{\circ} 41^{\prime} \mathrm{S}, 40^{\circ} 08^{\prime} \mathrm{W}, 450 \mathrm{~m}, 12$ jan. 1992 (fl., fr.), M.M. Arbo et al. 5456 (CTES, HUEFS, SPF); Ibotirama, $12^{\circ} 11^{\prime} \mathrm{S}, 43^{\circ} 13^{\prime} \mathrm{W}, 19$ mar. 1982 (fl., fr.), A. Krapovickas et al. 37932 (CTES); Itatim, margem da BR-101, $2 \mathrm{~km}$ da cidade, $12^{\circ} 42^{\prime} \mathrm{S}, 39^{\circ} 41^{\prime} \mathrm{W}, 4$ abr. 2013 (fr.), $L$. Rocha et al. 389 (HUEFS); Itiúba, 14-19 km W da sede, estrada para Filadélfia, 1042'S, 4000'W, 1 dez. 1992 (fl., fr.), M.M. Arbo et al. 5463 (CTES, HUEFS, SPF); Jacobina, Serra do Tombador, 19

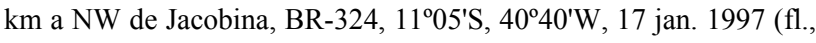
fr.), M.M. Arbo et al. 7398 (CEPEC, CTES, HUEFS); Jequié, BR$116,16 \mathrm{~km}$ após entroncamento de Jaguaquara, $13^{\circ} 51^{\prime} \mathrm{S}, 40^{\circ} 05^{\prime} \mathrm{W}$, 25 abr. 2013 (fl., fr.), L. Rocha \& P. Gomes 409 (CTES, HUEFS); Juazeiro, $09^{\circ} 41^{\prime} \mathrm{S}, 40^{\circ} 05^{\prime} \mathrm{W}, 8$ fev. 1970 (fl., fr.), A.L. Costa s.n. (ALCB 2844, CTES 44788); Licínio de Almeida, começo da trilha da Mata do Xaxá, 14³0'09"S, 42³2'48"W, 5 abr. 2013 (fl., fr.), $L$. Rocha et al. 394 (ALCB, HUEFS); Morro do Chapéu, BA-052, 18 $\mathrm{km}$ da cidade, estrada para a Cachoeira do Ferro Doido, $11^{\circ} 55^{\prime} \mathrm{S}$, $41^{\circ} 15^{\prime} \mathrm{W}, 28$ jan. 2013 (fl.), L. Rocha \& B.S. Gregório 383 (HUEFS); Oliveira dos Brejinhos, rodovia para Macaúbas, $\mathrm{Km} 8$, $12^{\circ} 19^{\prime} \mathrm{S}, 42^{\circ} 53^{\prime} \mathrm{W}, 20$ abr. 1996 (fl., fr.), G. Hatschbach et al. 65099a (CTES, MBM); Paramirim, estrada para a torre de TV, $13^{\circ} 27^{\prime} 07^{\prime \prime S}, 42^{\circ} 12^{\prime} 55^{\prime \prime W}, 600$ m, 30 jan. 2008 (fl., fr.), J.L. Ferreira et al. 285 (HUEFS); Porto Seguro, 16² $45^{\prime} \mathrm{S}, 39^{\circ} 06^{\prime} \mathrm{W}, 28$ maio 1962 (fl., fr.), A.P. Duarte 6630 (RB); Remanso, fazenda de Dona Bono, 09 $32^{\prime} 34^{\prime \prime S}, 41^{\circ} 53^{\prime} 36^{\prime \prime W}, 526$ m, 6 mar. 2008 (fl., fr.), C. Correia et al. 456 (HUEFS); Riachão das Neves, $12 \mathrm{~km} \mathrm{~N}$ da cidade, BR-135, $11^{\circ} 42^{\prime} \mathrm{S}, 45^{\circ} 00^{\prime} \mathrm{W}, 480 \mathrm{~m}, 1$ abr. 1983 (fl., fr.), A. Krapovickas et al. 38606 (CTES); Rio de Contas, Aeroporto, arredores, 13⒊' 41ํํ' W, 17 mar. 1998 (fl., fr.), G. Hatschbach et al. 67851 (CTES, MBM); Santa Cruz Cabrália, área da Estação Ecológica do Paubrasil, CEPLAC, $16^{\circ} 27^{\prime} \mathrm{S}, 39^{\circ} 02^{\prime} \mathrm{W}, 11$ jan. 1984 (f1.), F.S. Santos 101 (CEPEC); São Gabriel, fazenda Boa Sorte, $11^{\circ} 01^{\prime} \mathrm{S}, 41^{\circ} 29^{\prime} \mathrm{W}$, 798-800 m, 5 abr. 2009 (bot., fr.), R.F. Machado et al. 192 (HUEFS); Senhor do Bonfim, Carrapichel, 10 $22^{\prime} 47^{\prime \prime S}$, 4009'23"W, 538 m, 29 jul. 2005 (fl., fr.), P.D. Carvalho et al. 167 (HUEFS); Urandi, $7 \mathrm{~km}$ ao $\mathrm{N}$ da sede, $14^{\circ} 48^{\prime} \mathrm{S}, 42^{\circ} 38^{\prime} \mathrm{W}, 600 \mathrm{~m}, 20$ nov. 1992 (fl., fr.), M.M. Arbo et al. 5611 (CTES, SPF); Várzea 
Nova, BA-426, $7 \mathrm{~km}$ a SW da cidade, estrada para Morro do Chapéu, $11^{\circ} 18^{\prime} \mathrm{S}, 40^{\circ} 58^{\prime} \mathrm{W}, 17$ jan. 1997 (fl., fr.), M.M. Arbo et al. 7426 (CEPEC, CTES); Xique-Xique, $15 \mathrm{~km} \mathrm{~S}$, estrada para Santo Inácio, $10^{\circ} 58^{\prime} \mathrm{S}, 42^{\circ} 41^{\prime} \mathrm{W}, 19$ jan. 1997 (fl., fr.), M.M. Arbo et al. 7523 (CEPEC, CTES, HUEFS, MBM).

Pode ser reconhecida pelas flores pequenas, de corola creme ou amarela e base das pétalas amareloescura ou com estrias marrons, além dos frutos densohirsutos apenas no ápice e sementes lunadas, com nós do retículo proeminentes. As flores foram encontradas abertas até 11:00 hs. Arbo (2008) considerou duas variedades para esta espécie, ambas ocorrentes na Bahia: $T$. pumilea var. pumilea com flores homostilas e $T$. pumilea var. piauhyensis Urb. com flores heterostilas.

2.34. Turnera scabra Millsp., Publ. Field Columb. Mus., Bot. Ser. 2(1): 77. 1900.

Figuras 41; Arbo (2005: fig. 56A-E); Rocha \& Moreira (2014: foto 89).

Subarbustos 0,3-1 m alt.; caules estrigosos a denso-estrigosos, tricomas tectores simples. Estípulas 2, rudimentares. Folhas com pecíolo 2-16 mm compr.; nectários 2, 0,7-1 mm diâm.; lâmina 0,9-4,6 × 0,5-1,5 $\mathrm{cm}$, papirácea, concolor, ovada, largo-ovada, elíptica a lanceolada, base atenuada a cuneada, ápice agudo, raro obtuso, margens duplamente serreadas a serreadocrenadas, planas; face adaxial estrigosa, nervuras impressas, face abaxial denso-estrigosa, nervuras proeminentes. Inflorescências unifloras, solitárias a agrupadas no ápice dos ramos; pedúnculo 3-10 mm compr., 2-9 $\mathrm{mm}$ adnato ao pecíolo; brácteas ausentes; bractéolas 5-15 $\mathrm{mm}$ compr., lineares a lineartriangulares. Flores heterostilas, epífilas; pedicelo ausente. Cálice 1,1-2,1 cm compr., externamente denso-estrigoso. Corola 1,5-2,7 cm compr., amarela ou creme, base das pétalas amarela-escura ou com estrias alaranjadas. Filetes 8,5-10 $\mathrm{mm}$ compr. em flores brevistilas, 3-4 $\mathrm{mm}$ compr. em flores longistilas, glabros, margens ca. 2-3 $\mathrm{mm}$ adnatas à unha das pétalas, formando sacos nectaríferos; anteras 3-3,3 $\mathrm{mm}$ compr., dorsifixas. Ovário 1-1,5 mm compr., tomentoso; estiletes 4,5-5,5 $\mathrm{mm}$ compr. em flores brevistilas, 7-8 $\mathrm{mm}$ compr. em flores longistilas, glabros; estigmas penicelados. Cápsulas 5-6 $\mathrm{mm}$ diâm.; epicarpo verrucoso, denso-piloso. Sementes 2 $2,5 \times$ ca. $1 \mathrm{~mm}$, estreito-obovoides a claviformes, ligeiramente curvas, reticuladas; epiderme lisa; calaza obtusa, superfície plana.

Amplamente distribuída, do sul do México até a Colômbia, Venezuela e Guianas. No Brasil, ocorre no Nordeste, Centro-Oeste, Norte (exceto Acre e Roraima) e Sudeste (Minas Gerais) (Arbo 2005, 2015). C8, D10, E9, F8: caatingas, restingas e dunas. Habita áreas abertas, por vezes perturbadas, como margens de rodovias. Cresce em substratos arenosos. Apresenta flores e frutos de junho a dezembro.

Material selecionado - Conde, Fazendinha, $11^{\circ} 48^{\prime} \mathrm{S}, 37^{\circ} 36^{\prime} \mathrm{W}$, 20 jun. 2003 (fl., fr.), G. Hatschbach et al. 75567 (CTES, MBM); Queimadas, $10^{\circ} 58^{\prime} 00^{\prime \prime} \mathrm{S}, 39^{\circ} 36^{\prime} 00^{\prime \prime} \mathrm{W}, 17$ nov. 1986 (fl., fr.), L.P.
Queiroz et al. 1150 (HUEFS); Salvador, Parque Metropolitano de Pituaçu, 1256'44"S, 38²4'59"W, 6 dez. 1997 (fl., fr.), A.S. Conceição 120 (CTES, HRB); Valença, Guaibim, 13⒊ $36^{\prime} \mathrm{S}$, $39^{\circ} 07^{\prime} \mathrm{W}, 14$ out. 1998 (fl., fr.), G. Hatschbach et al. 68516 (CTES, MBM).

Pode ser reconhecida pelas flores heterostilas, de corola creme ou amarela, base das pétalas amareloescura com estrias alaranjadas e sementes estreitoovadas a claviformes. A espécie mais próxima de Turnera scabra é T. subulata, a qual se diferencia pelas pétalas geralmente brancas ou creme com base enegrecida. Quando secos, os espécimes de T. scabra são similares a $T$. cuneiformis e $T$. orientalis, ambas se diferenciam pelas flores homostilas.

2.35. Turnera simulans Arbo, Bonplandia 5(14): 111. 1981.

Figuras 41; Arbo (2005: fig. 33A-Q); Rocha \& Moreira (2014: fotos 90-92).

Subarbustos ou arbustos $0,15-1,8 \mathrm{~m}$ alt.; caules esparso a denso-estrigosos, tricomas tectores simples e glandulares microcapitados. Estípulas 2, 0,3-1 $\mathrm{mm}$ compr. Folhas com pecíolo $1-5 \mathrm{~mm}$ compr.; nectários 2, 0,3-0,6 mm diâm.; lâmina 0,7-3,5(-5,5) × 0,3-2 cm, cartácea, concolor a ligeiramente discolor, ovada, elíptica, elíptico-obovada, base atenuada a cuneada, ápice agudo ou obtuso, margens serreadas a serrilhadas, ligeiramente revolutas; face adaxial estrigosa, nervuras impressas, face abaxial densoestrigosa, nervuras proeminentes, ferrugíneas. Inflorescências unifloras, solitárias a agrupadas no ápice dos ramos; pedúnculo 1-3 mm compr., 1-2 mm adnato ao pecíolo; bráctea ausente; bractéolas 4,5-10 $\mathrm{mm}$ compr., linear-triangulares. Flores heterostilas, epífilas; pedicelo ausente. Cálice 7-13 mm compr., externamente denso-estrigoso. Corola 9-20 mm compr., amarela. Filetes 7-10 mm compr. em flores brevistilas, 3-5 $\mathrm{mm}$ compr. em flores longistilas, glabros, margens $1-2,5 \mathrm{~mm}$ adnatas à unha das pétalas, formando sacos nectaríferos; anteras 1-1,7 mm compr., basifixas. Ovário 1-1,7 $\mathrm{mm}$ compr., tomentoso; estiletes ca. 3,5 $\mathrm{mm}$ compr. em flores brevistilas, 4-8 $\mathrm{mm}$ compr. em flores longistilas, esparso-pilosos; estigmas penicelados. Cápsulas 5-6 $\mathrm{mm}$ diâm.; epicarpo verrucoso, esparso-hirsuto. Sementes 1,7-3 $\times$ 0,7-1,3 mm, estreito-oblongas, curvas, reticuladas; epiderme lisa; calaza proeminente, superfície côncava, umbilicada.

Endêmica da região central da Bahia (Arbo 2005). C6, D6, E6, F6, G6: cerrados, campos rupestres e campos gerais. Habita áreas abertas, por vezes perturbadas, como terrenos baldios, margens de trilhas ou rodovias. Cresce em substratos arenosos e rochosos, em altitudes até $1410 \mathrm{~m}$. Encontrada com flores e frutos durante a maior parte do ano.

Material selecionado - Abaíra, Serrinha, $13^{\circ} 19^{\prime} \mathrm{S}, 41^{\circ} 51^{\prime} \mathrm{W}$, 1410 m, 18 nov. 1992 (fl., fr.), W. Ganev 1498 (CTES, HUEFS, $\mathrm{SPF}$ ); Barra da Estiva, $8 \mathrm{~km} \mathrm{~S}$ de Barra da Estiva, estrada para Ituaçu, Morro do Ouro e Morro da Torre, $13^{\circ} 40^{\prime} \mathrm{S}, 41^{\circ} 14^{\prime} \mathrm{W}, 1190$ 
m, 22 nov. 1992 (fl., fr.), M.M. Arbo et al. 5710 (CTES, HUEFS, MBM, SPF, RB, UB); Brumado, Barra do Brumado, $14^{\circ} 12^{\prime} \mathrm{S}$, 4139'W, 7 abr. 1992 (fl., fr.), G. Hatschbach et al. 56824 (CTES, MBM); Cascavel, $13^{\circ} 17^{\prime} \mathrm{S}, 41^{\circ} 21^{\prime} \mathrm{W}, 24$ mar. 2005 (fl., fr.), L.S. Funch \& R. Funch 775 (CTES, HUEFS); Lençóis, 12³4'00"S, 4122'59"W, 7 fev. 2009 (fl.), J.C. Brito 75 (HUEFS); Morro do Chapéu, morrão, $11^{\circ} 55^{\prime} \mathrm{S}, 41^{\circ} 15^{\prime} \mathrm{W}, 28$ jan. 2013 (fl., fr.), L. Rocha \& B.S. Gregório 380 (CTES, HUEFS, RB); Mucugê, $3 \mathrm{~km}$ ao $\mathrm{S}$ de Mucugê, estrada para Jussiape, $13^{\circ} 00^{\prime} \mathrm{S}, 41^{\circ} 24^{\prime} \mathrm{W}, 1000 \mathrm{~m}, 26$ jul. 1979 (fl., fr.), S.A. Mori et al. 12651 (holótipo CEPEC, isótipos CTES, RB); ib., $13^{\circ} 00^{\prime} \mathrm{S}, 4^{\circ} 23^{\prime} \mathrm{W}, 16$ dez. 2005 (fl., fr.), V.S. Ferreira et al. 69 (HUEFS, SP); Palmeiras, 12³4'00"S, 4122'59"W, 22 ago. 2009 (fl., fr.), J.C. Brito \& J. Marques 152 (HUEFS); Piatã, estrada para Inúbia, 130.'28"S, 41 $55^{\circ} 42^{\prime \prime W}, 1402$ m, 12 dez. 2009 (fl.), D. Cardoso et al. 2820 (CTES, HUEFS); Rio de Contas, arredores do povoado de Mato Grosso, 13²6'25"S, 4150'21"W, 27 set. 2010 (fl., fr.), R.M. Harley \& J.F.B. Pastore 56170 (HUEFS); Seabra, na direção de Campestre, $12^{\circ} 25^{\prime} \mathrm{S}$, 41ํ6'W, 930 m, 15 nov. 1983 (fl.), G.C.P. Pinto 408a/83 (MBM, RB, UB); Umburanas, Delfino, estrada para Campo Formoso, $10^{\circ} 21^{\prime} 49^{\prime \prime S}, 41^{\circ} 11^{\prime} 44^{\prime \prime W}, 925$ m, 28 jun. 2004 (fl., fr.), M. Machado 230 (HUEFS).

Pode ser reconhecida pelas folhas geralmente pequenas, serreadas a serrilhadas, onde a face abaxial apresenta nervuras ferrugíneas, além da corola totalmente amarela e sementes com superfície da calaza umbilicada. As flores foram encontradas abertas até 15:00 hs; visitadas por besouros e diversas espécies de formigas, estas últimas também presentes nos nectários extraflorais. Turnera simulans é semelhante a $T$. leptosperma e $T$. joelii, a primeira se diferencia pelas folhas geralmente maiores, com face abaxial tomentosa, cinérea quando seca, e corola amarela com estrias marrom-avermelhadas; enquanto que a segunda apresenta folhas papiráceas geralmente maiores.

2.36. Turnera stachydifolia Urb. \& Rolfe, Jahrb. Königl. Bot. Gart. Berlin 2: 122. 1883.

Figura Arbo (2008: fig. 76A-N).

Arbustos ca. $1 \mathrm{~m}$ alt.; caules em zigue-zague, denso-lanosos, tricomas tectores simples e glandulares capitado-sésseis. Estípulas 2, 0,9-1,2 $\mathrm{mm}$ compr. Folhas com pecíolo 3-7 mm compr.; nectários 2, 0,3$0,5 \mathrm{~mm}$ diâm., apenas nas folhas floríferas; lâmina 1,6 $5,1 \times 0,8-1,4 \mathrm{~cm}$, cartácea, ligeiramente discolor, elíptica a elíptico-obovada, base atenuada a cuneada, ápice obtuso ou agudo, margens duplamente serreadocrenadas, ligeiramente revolutas; face adaxial lanosotomentosa, nervuras impressas, face abaxial lanosotomentosa, nervuras proeminentes. Inflorescências unifloras, agrupadas em racemos terminais; pedúnculo 1,5-2,5 mm compr., totalmente adnato ao pecíolo; brácteas ausentes; bractéolas 1,5-2 $\mathrm{mm}$ compr., lineares. Flores heterostilas, epífilas; pedicelo ausente. Cálice 6-6,5 $\mathrm{mm}$ compr., externamente lanosotomentoso. Corola ligeiramente maior que o cálice, amarela. Filetes ca. $6 \mathrm{~mm}$ compr., em flores brevistilas, esparso-pilosos, base ca. $0,5 \mathrm{~mm}$ adnata ao tubo floral; anteras $0,7-0,9 \mathrm{~mm}$ compr., dorsifixas. Ovário ca. 1 mm compr., hirsuto; estiletes ca. 2,5 mm compr. em flores brevistilas, esparso-pilosos; estigmas penicelados. Cápsulas 3-4 mm diâm.; epicarpo liso, viloso-hirsuto. Sementes 2-2,5 $\times 1-1,1 \mathrm{~mm}$, obovoides, ligeiramente curvas, reticuladas; epiderme papilosa; calaza proeminente, superfície côncava.

São conhecidos apenas os materiais-tipo, com localidade incerta, provavelmente coletados na região do Médio São Francisco no estado da Bahia. Encontrada com flores e frutos no mês de janeiro.

Material examinado - Barra, Ibiraba, "Marais d'Ithabira, Rio Sn. Francisco", 11 jan. 1905 (fl., fr.), J.S. Blanchet 2873 (holótipo F [foto 13603], isótipos K-foto, M-foto, P-foto, SP).

Arbo (2008) considerou duas variedades para esta espécie: T. stachydifolia var. stachydifolia e $T$. stachydifolia var. flexuosa Urb.; apenas esta última ocorre na Bahia. Pode ser reconhecida pelos ramos em zigue-zague, indumento com tricomas glandulares capitado-sésseis e folhas com margens duplamente serreado-crenadas, lanoso-tomentosas nas duas faces. A variedade típica é endêmica do Piauí, e se diferencia pelos ramos retos e bractéolas menores. Turnera stachydifolia se assemelha a $T$. vallsii Arbo, endêmica de Goiás, a qual pode ser diferenciada pelos filetes glabros e ausência de tricomas glandulares capitadosésseis. O único registro para o estado da Bahia data de mais de 100 anos atrás e as informações sobre seu hábitat são incertas.

2.37. Turnera stenophylla Urb., Repert. Spec. Nov. Regni Veg. 4: 136. 1907.

Figuras 15A e 42; Arbo (2008: fig. 35A-G).

Arbustos ou subarbustos 0,5-2,2 m alt; caules estrigosos, tricomas tectores simples. Estípulas 2, 0,6$1 \mathrm{~mm}$ compr. Folhas com pecíolo 0,5-4 mm compr.; nectários 1 ou 2 pares, $0,5-1,3 \mathrm{~mm}$ diâm.; lâmina $1,2-$ $4 \times 0,2-1 \mathrm{~cm}$, papirácea, concolor, linear a linearlanceolada, base atenuada a cuneada, ápice agudo ou acuminado, margens inteiras, planas; face adaxial esparso-estrigosa, apenas a nervura principal evidente, castanho-avermelhada, face abaxial estrigosa, nervuras castanho-avermelhadas. Inflorescências unifloras, solitárias; pedúnculo 2-3 $\mathrm{mm}$ compr., ca. $2 \mathrm{~mm}$ adnato ao pecíolo; brácteas ausentes; bractéolas 7-13 $\mathrm{mm}$ compr., linear-triangulares. Flores heterostilas, epífilas; pedicelo ausente. Cálice 8,5-13 mm compr., externamente esparso-estrigoso. Corola 1,3-1,8 cm compr., amarela. Filetes ca. $7 \mathrm{~mm}$ compr. em flores brevistilas, 3,5-5 $\mathrm{mm}$ compr. em flores longistilas, esparso-pilosos, margens $2-3 \mathrm{~mm}$ adnatas ao tubo floral, formando sacos nectaríferos; anteras 2-3,5 mm compr., basifixas. Ovário 1,3-2 $\mathrm{mm}$ compr., tomentoso; estiletes ca. $4 \mathrm{~mm}$ compr. em flores brevistilas, 6-7 $\mathrm{mm}$ compr. em flores longistilas, esparso-pilosos; estigmas penicelados. Cápsulas 4,5-5 $\mathrm{mm}$ diâm.; epicarpo verrucoso, estrigoso. Sementes 2,5-4 × 1-1,2 mm, obovoides, curvas, tenuamente reticuladas; epiderme lisa; calaza proeminente, superfície côncava, umbilicada. 
Endêmica da região norte da Bahia (Arbo 2005). D5: campos rupestres e áreas de transição entre cerrado/caatinga. Ocorre principalmente em áreas abertas, por vezes perturbadas, como margens de rodovias. Cresce em substratos arenosos e rochosos, em altitudes até $932 \mathrm{~m}$. Apresenta flores e frutos a maior parte do ano.

Material selecionado - Gentio do Ouro, "Serra do S. Inácio", jan. 1907 (fl., fr.), E. Ule 7217 (holótipo F [foto 13604], isótipos HBG, K); ib., estrada para Itajubaquara, $11^{\circ} 18^{\prime} 41^{\prime \prime} \mathrm{S}, 42^{\circ} 40^{\prime} 23^{\prime \prime} \mathrm{W}$, 932 m, 26 maio 2009 (fl., fr.), M. Oliveira et al. 4202 (CTES, HVASF); Xique-Xique, ca. $33 \mathrm{~km}$ a $\mathrm{SW}$ da cidade, estrada para

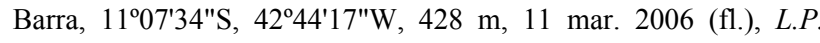
Queiroz et al. 12164 (CTES, HUEFS).

Pode ser reconhecida pelas folhas lanceoladas, com face adaxial esparso-estrigosa e nervuras castanhoavermelhadas, evidentes nas duas faces. Turnera stenophylla se assemelha a $T$. arcuata Urb., endêmica de Goiás, a qual se diferencia pelo porte geralmente menor e folhas com apenas uma nervura evidente, da mesma cor que a lâmina.

2.38. Turnera subulata Sm. in Rees, Cycl. 36(2): 441. 1817.

Figuras 15B-D e 42; Arbo (2005: fig. 56F-J); Rocha \& Moreira (2014: fotos 93-95).

Ervas a subarbustos 0,2-1,5 m alt.; caules estrigosos a denso-estrigosos, tricomas tectores simples e glandulares microcapitados. Estípulas 2, rudimentares. Folhas com pecíolo 5-17 mm compr.; nectários 2-4, 0,5-1,5 mm diâm.; lâmina 1-7,5 4×0,34,2 cm, papirácea, ligeiramente discolor, ovada, elíptica, obovada a lanceolada, ápice agudo a obtuso, margens simples ou duplamente serreado-crenadas ou serrilhadas, planas, base cuneada a atenuada; face adaxial estrigosa, nervuras impressas, face abaxial denso-estrigosa, nervuras proeminentes. Inflorescências unifloras, solitárias a agrupadas no ápice dos ramos; pedúnculo 5-7 $\mathrm{mm}$ compr., totalmente adnato ao pecíolo; brácteas ausentes; bractéolas 7-15 mm compr., linear-triangulares. Flores heterostilas, epífilas; pedicelo ausente. Cálice 1,8-2 cm compr., externamente denso-estrigoso. Corola 3-4 cm compr., amarela a creme, base das pétalas castanhoescura. Filetes 9-11 mm compr. em flores brevistilas, 5,5-6,5 compr. em flores longistilas, glabros, margens 2-5 mm adnatas à unha das pétalas, formando sacos nectaríferos; anteras 3-3,5 mm compr., basifixas. Ovário ca. $2 \mathrm{~mm}$ compr., tomentoso; estiletes 1-3 mm compr. em flores brevistilas, 5-6 cm compr. em flores longistilas, glabros; estigmas penicelados. Cápsulas 6 $7 \mathrm{~mm}$ diâm.; epicarpo verrucoso, estrigoso. Sementes 2-3 × 1-1,3 mm, estreito-obovoides, ligeiramente curvas, reticuladas; epiderme lisa; calaza obtusa, superfície plana.

Distribui-se no Panamá, Colômbia, Venezuela, Guiana Francesa, Equador e norte da Bolívia (Arbo 2005). Foi introduzida na Ásia, ocorrendo na Indonésia, Malásia, Singapura, Sri Lanca e Tailândia
(Madhusoodanan \& Rejani 1989; Kumar \& Vinesh 2000). Na África, ocorre em Madagáscar e Seicheles (Brizicky 1961). No Brasil, está representada na maioria dos estados, exceto Acre e Roraima (no Norte) e todos aqueles da região Sul (Arbo 2015). B8, B9, C8, C9, D7, D8, E6, E9, E10, F4, G8, H9: caatingas e matas ombrófilas. Habita áreas abertas, por vezes, perturbadas como margens das rodovias, pastos e zona urbana. Cresce em substratos arenosos, rochosos e argilosos, em altitudes até $500 \mathrm{~m}$. Apresenta flores e frutos durante o ano todo.

Material selecionado - Bom Jesus da Lapa, $13^{\circ} 25^{\prime} \mathrm{S}$, 43ํ1'W, 9 ago. 1996 (fl., fr.), M.S. Ferrucci et al. 994 (CEPEC, CTES, HUEFS, MBM); Camaçari, Praia de Juá, $12^{\circ} 41^{\prime} \mathrm{S}, 38^{\circ} 19^{\prime} \mathrm{W}$, 31 dez. 2007 (fl., fr.), J.A.S. Costa \& C.B.N. Costa 1454 (BRBA); Canavieiras, Ilha de Atalaia, ca. $1 \mathrm{~km}$ após a ponte rumo ao Sul, $15^{\circ} 40^{\prime} \mathrm{S}, 38^{\circ} 56^{\prime} \mathrm{W}, 10$ jan. 1996 (fl.), A.M. Argolo et al. 4 (CEPEC); Conde, Fazenda do Bu, 1203'10"S, 3743'17"W, 15 ago. 1996 (fl., fr.), A.S. Conceição et al. 34 (CEPEC, CTES, HRB, MBM, RB); Feira de Santana, Campus da UEFS, LABIO, $12^{\circ} 15^{\prime} 00^{\prime \prime} \mathrm{S}$, 38 58'00"W, 23 jan. 2009 (fl., fr.), C. Chamusca 5 (HUEFS); Glória, povoado de Brejo do Burgo, 09³3'S, 38²5'W, 1 jul. 1995 (fl., fr.), F.P. Bandeira 171 (HUEFS); Ilhéus, rua do Pontalzinho,

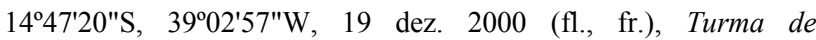
Sistemática de Fanerógamas s.n. (ALCB 58491, HUEFS 60167); Itabuna, Rua Rio Branco, 14\% $47^{\prime} \mathrm{S}, 39^{\circ} 16^{\prime} \mathrm{W}, 14$ fev. 2001 (fl., fr.), M.L.O. Brandão et al. 1 (CEPEC, HUEFS); Itacaré, entrada ca. 1 km da BR-101, 14 ${ }^{\circ} 19^{\prime} 19^{\prime \prime} S, 39^{\circ} 17^{\prime} 13^{\prime \prime W}, 7$ ago. 1998 (fr.), S.C. Sant'Ana et al. 662 (CEPEC, CTES); Jacobina, BR-324, $18 \mathrm{~km}$ a E de Jacobina, estrada para Capim Grosso, $11^{\circ} 13^{\prime} \mathrm{S}, 40^{\circ} 22^{\prime} \mathrm{W}, 500 \mathrm{~m}$, 30 nov. 1992 (fl., fr.), M.M. Arbo et al. 5451 (CTES, HUEFS, SPF, UB); Jeremoabo, Raso da Catarina, central da SEMA, $10^{\circ} 06^{\prime} \mathrm{S}$, 38³4'W, 20 jun. 1981 (fl.), M.L. Guedes 290 (ALCB); Lauro de Freitas, Areia Branca, 10³9'S, 3944'W, 25 mar. 2004 (fl., fr.), M.V. Moraes 634 (HUEFS); Lençóis, vale do rio São José, 12³3'47"S, 41'23'24"W, 28 jul. 1998 (fl., fr.), R. Funch 120 (HUEFS); Queimadas, 1059'S, 39³8'W, 15 jan. 1997 (fl., fr.), M.M. Arbo et al. 7273 (CEPEC, CTES); Riachão do Jacuípe, 13 $\mathrm{km}$ a SE da cidade, BR-324, $11^{\circ} 22^{\prime} \mathrm{S}, 39^{\circ} 49^{\prime} \mathrm{W}, 10$ jul. 1985 (fl., fr.), L.R. Noblick \& Lemos 4100 (CEPEC, CTES, HUEFS, MBM); Rodelas, Itacotiara, $08^{\circ} 51^{\prime} \mathrm{S}, 38^{\circ} 45^{\prime} \mathrm{W}, 21$ jan. 1987 (fl., fr.), L.B. Silva \& G.O. Matos-Silva 39 (ALCB); Salvador, dunas do Flamengo, APA das Dunas e Lagoa do Abaeté, $12^{\circ} 58^{\prime} \mathrm{S}, 38^{\circ} 30^{\prime} \mathrm{W}, 5$ jul. 2008 (fl., fr.), F.O. Silva et al. 68 (ALCB); Santa Brígida, Núcleo do Raso da Catarina, 0944'S, 3807'W, 17 maio 1981 (fl., fr.), H.P. Bautista 461 (CEPEC, HUEFS, R, RB); Simões Filho, Estação de Goes-Calmon, 1247'S, 38²4'W, 28 set. 1975 (fl., fr.), $P$. Gildo s.n. (ALCB 2847, CTES 44782, IPA 54278).

Pode ser reconhecida pelas flores heterostilas com pétalas amarelas a creme, passando a castanho-escuras na base. Tem sido equivocadamente identificada como Turnera ulmifolia L., que não ocorre no Brasil e possui flores homostilas e amarelas (Arbo 2005). Também se assemelha a $T$. scabra, a qual se diferencia pelas pétalas amarelas com estrias alaranjadas e base amarelo-escura. Segundo Arbo (2005), a fácil hibridação de $T$. subulata e $T$. scabra pode gerar plantas cujas flores possuem pétalas enegrecidas na base ou totalmente amarela (Arbo \& Fernández 1987; 
Fernández \& Arbo 1989). As flores foram encontradas abertas até 13:00 hs; visitadas por aranhas e diversos insetos: abelhas, vespas, moscas, besouros e borboletas, além de diversas espécies de formigas. Há uma espécie de abelha endêmica do Nordeste, Protomeliturga turnerae (Ducke, 1907) (Hymenoptera, Andrenidae), que se alimenta do néctar e coleta pólen quase exclusivamente de T. subulata (Medeiros \& Schlindwein 2003).

\subsection{Turnera trigona Urb., Jahrb. Königl. Bot. Gart.} Berlin 2: 111. 1883.

Figuras 15E e 43; Arbo (2008: fig. 79A-O); Rocha \& Moreira (2014: fotos 96-100).

Ervas ca. $50 \mathrm{~cm}$ alt.; caules glabros, marcadamente angulosos. Estípulas 2, rudimentares. Folhas com pecíolo ca. 0,3 mm compr.; nectários até 2 , 0,3-0,7 mm diâm., em todas as folhas; lâmina 3-35 × 11,5 mm, cartácea, concolor, estreito-lanceolada, base atenuada, ápice agudo, margens inteiras a discretamente serrilhadas, ligeiramente revolutas, as duas faces glabras, com nervuras proeminentes. Inflorescências unifloras, solitárias ou agrupadas no ápice dos ramos; pedúnculo 1-2 $\mathrm{mm}$ compr.; totalmente adnato ao pecíolo; bráctea ausente; bractéolas ca. $2 \mathrm{~mm}$ compr., lineares. Flores heterostilas, epífilas; pedicelo ausente. Cálice ca. 7 mm compr., esparso-estrigoso. Corola ca. 9 mm compr., amarela. Filetes 3-4 mm compr. em flores brevistilas, ca. $3 \mathrm{~mm}$ compr. em flores longistilas, glabros, base ca. $0,5 \mathrm{~mm}$ adnata ao tubo floral; anteras ca. $1 \mathrm{~mm}$ compr., dorsifixas. Ovário ca. $1 \mathrm{~mm}$ compr., denso-piloso; estiletes 0,9-1,5 $\mathrm{mm}$ compr. em flores brevistilas, ca. $3 \mathrm{~mm}$ compr. em flores longistilas, glabros; estigmas penicelados. Cápsulas 3-5 mm diâm.; epicarpo liso, denso-piloso. Sementes ca. $2 \times 1 \mathrm{~mm}$, obovoides, ligeiramente curvas, reticuladas; epiderme lisa; calaza pouco proeminente, superfície côncava.

Ocorre em Goiás, Tocantins, Minas Gerais e Distrito Federal (Arbo 2015). Através deste estudo, amplia-se sua área de distribuição para o estado da Bahia. E3: cerrados. Foi coletada com flores no mês de julho, em áreas abertas e sujeitas à ação do fogo.

Material examinado - Barreiras, Serra do Mimo, $12^{\circ} 09^{\prime} \mathrm{S}$, 4459'W, 9 jul. 2009 (fl.), B.T.C. Santos et al. 491 (BRBA); ib., Serra da Bandeira, fazenda Riacho da Serra, $12^{\circ} 09^{\prime} \mathrm{S}, 44^{\circ} 59^{\prime} \mathrm{W}, 29$ dez. 2012 (fl., fr.), G.O. Almeida \& I.S. Oliveira 723 (BRBA).

Material adicional examinado - BRASIL. GOIÁS: Niquelândia, nas margens do rio Tocantinzinho $13^{\circ} 59^{\prime} \mathrm{S}, 48^{\circ} 18^{\prime} \mathrm{W}$, 400 m, 22 jul. 1995 (fl., fr.), T.B. Cavalcanti et al. 1576 (CEN).

Pode ser reconhecida pelos caules angulosos, verdeclaros, com seção triangular a pentagonal, ao menos na porção mediana, além das folhas glabras, flores com cálice esparso-estrigoso e corola amarela. Turnera trigona é similar a T. subnuda Urb., que não ocorre na Bahia e que se diferencia pelos ramos adultos geralmente cilíndricos, folhas filiformes a lineares, geralmente desprovidas de nectários e menores (3-15× 0,3-1,5 mm vs. $1,3-48 \times 0,3-3 \mathrm{~mm}$ em $T$. trigona $)$.
2.40. Turnera uleana Urb. Repert. Spec. Nov. Regni Veg. 4: 132. 1907.

Figuras 43; Arbo (2008: fig. 80A-O).

Subarbustos $0,7-1 \mathrm{~m}$ alt.; caules viloso-hirsutos, ramos jovens lanosos, tricomas tectores simples. Estípulas 2, rudimentares. Folhas com pecíolo 2-4 mm compr.; nectários 2, 0,3-0,7 mm diâm., em todas as folhas; lâmina 8-25 × 7-15 mm, papirácea, discolor, ovada, estreito-ovada a elíptico-ovada, base cuneada, ápice agudo, margens serreadas a crenadas, fortemente revolutas; face adaxial tomentosa, nervuras fortemente impressas, face abaxial lanosa a lanoso-velutina, nervuras proeminentes. Inflorescências unifloras; solitárias ou agrupadas no ápice dos ramos; pedúnculo 2-3 mm compr., totalmente adnato ao pecíolo; bráctea ausente; bractéolas 5-10 mm compr., linear-triangulares. Flores heterostilas, epífilas; pedicelo ausente. Cálice 11,2 cm compr., externamente viloso. Corola 1-1,2 mm compr., amarela. Filetes 6-7,5 mm compr. em flores brevistilas, ca. $5 \mathrm{~mm}$ compr. em flores longistilas, glabros, base ca. $0,5 \mathrm{~mm}$ adnata ao tubo floral; anteras ca. 0,9 mm compr., dorsifixas. Ovário ca. 0,7 mm compr., tomentoso; estiletes 3-3,5 mm compr. em flores brevistilas, ca. $4 \mathrm{~mm}$ em flores longistilas, esparsopilosos; estigmas penicelados. Cápsulas 3-4 mm diâm.; epicarpo liso, denso-piloso. Sementes 2-2,5 × 1-1,1 $\mathrm{mm}$, obovoides, ligeiramente curvas; epiderme com cera epicuticular filiforme; calaza obtusa, superfície com uma proliferação dérmica da rafe.

Endêmica do estado da Bahia. B5, C5, F5: caatingas e cerrados. Cresce em substratos arenosos e rochosos, em altitudes de 437-1100 m. Apresenta flores e frutos em dezembro e abril.

Material selecionado - Água Quente, Pico das Almas, Vertente $\mathrm{W}$, entre Paramirim das Crioulas e a face NNW do Pico, $13^{\circ} 21^{\prime} \mathrm{S}$, 42 $00^{\prime}$ W, 1100 m, 17 dez. 1988 (fl., fr.), R.M. Harley \& B. Stannard 27568 (CEPEC, CTES, SPF); Pilão Arcado, $1 \mathrm{~km}$ depois da ponte sobre o riacho de lage, $30 \mathrm{~km}$ de Remanso na estrada para Pilão Arcado, 09 $45^{\prime} 32^{\prime \prime S}, 42^{\circ} 17^{\prime} 53^{\prime \prime} \mathrm{W}, 437$ m, 28 abr. 2001 (fl., fr.), L.P. Queiroz et al. 6601 (HUEFS); Remanso, 09²37'S, 4204'W, dez. 1906 (fl., fr.), E. Ule 7502 (holótipo F-foto, isótipos K-foto).

Pode ser reconhecida pelas folhas com face abaxial lanosa a vilosa, marcadamente cinérea quando seca e sementes de calaza com uma proliferação dérmica da rafe. O exemplar Harley 27568 apresenta características semelhantes ao holótipo, mas é um subarbusto ereto, com entrenós longos, lembrando Turnera luetzelburgii var. luetzelburgii, a qual se diferencia pelas folhas com margens denteadas a profundamente laciniadas e sementes com calaza cônica e saliente. Os poucos exemplares conhecidos foram coletados em áreas sujeitas a ação antrópica, o que pode representar risco para a manutenção dos seus hábitats.

\section{Agradecimentos}

Aos curadores dos herbários visitados, por viabilizarem o acesso às coleções; à CAPES, pela bolsa 


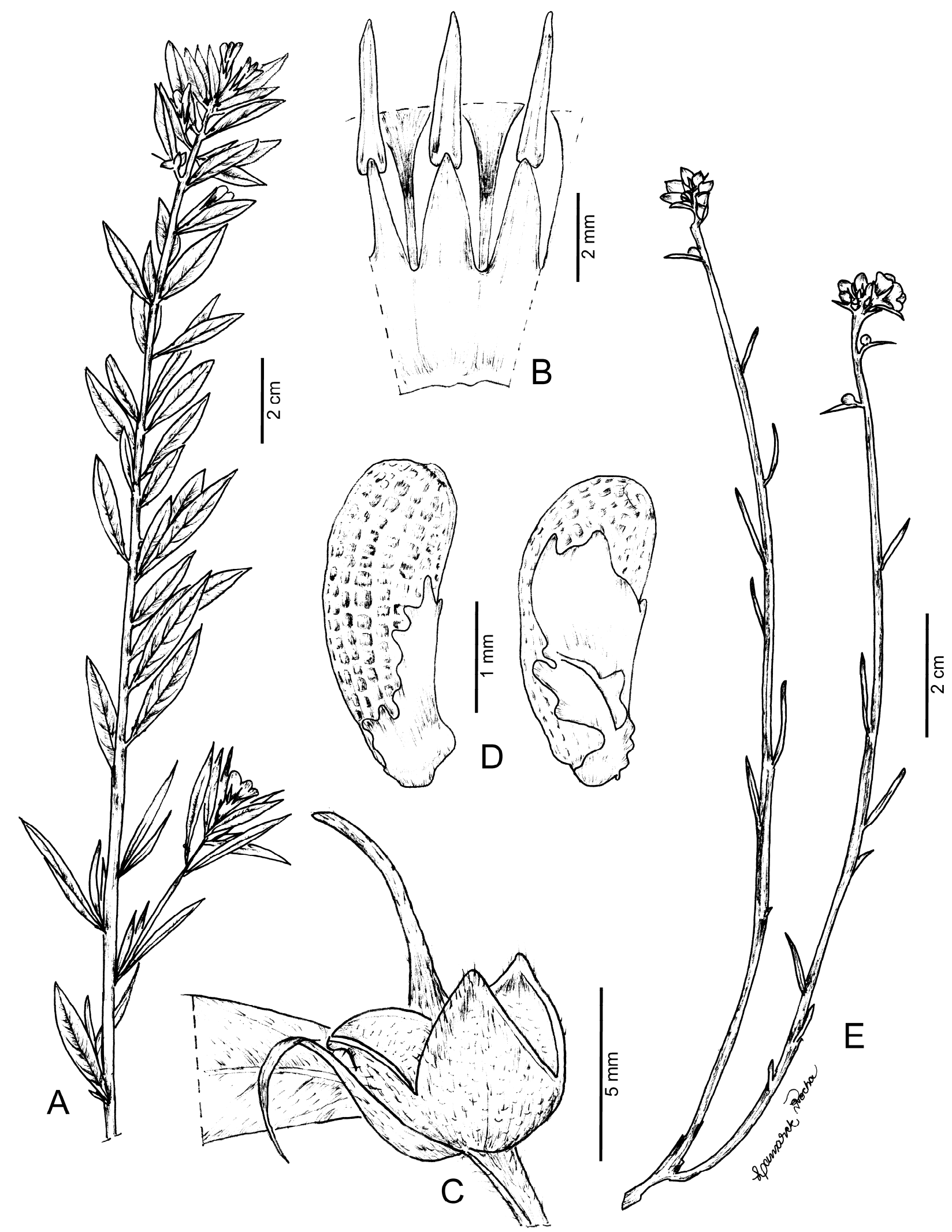

Figura 15. A. Turnera stenophylla: ramo reprodutivo (Nunes 979). B-D. T. subulata: B- flor dissecada evidenciando parte do androceu (flor longistila); C- fruto com bractéolas; D- semente (Brandão 1). E. T. trigona: ramo reprodutivo (Cavalcanti 1576).

de mestrado concedida a LR; ao CNPq, pela bolsa de produtividade (Pq1D) de AR e pelo apoio ao projeto Flora da Bahia (PROTAX e Universal 485468/2013-1); aos revisores, pelo empenho na melhoria do manuscrito; e, especialmente, à Dra. María de Mercedes Arbo, grande especialista em Turneraceae, pelo constante auxílio e importantíssimas contribuições. 


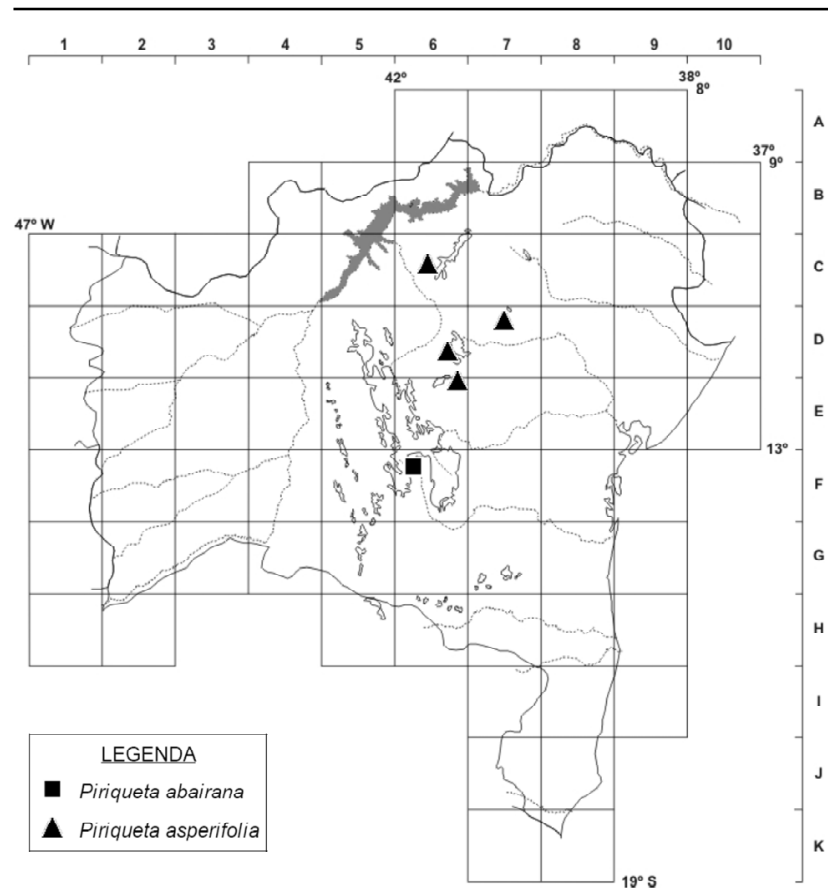

Figura 16. Distribuição de Piriqueta abairana e P. asperifolia no estado da Bahia.

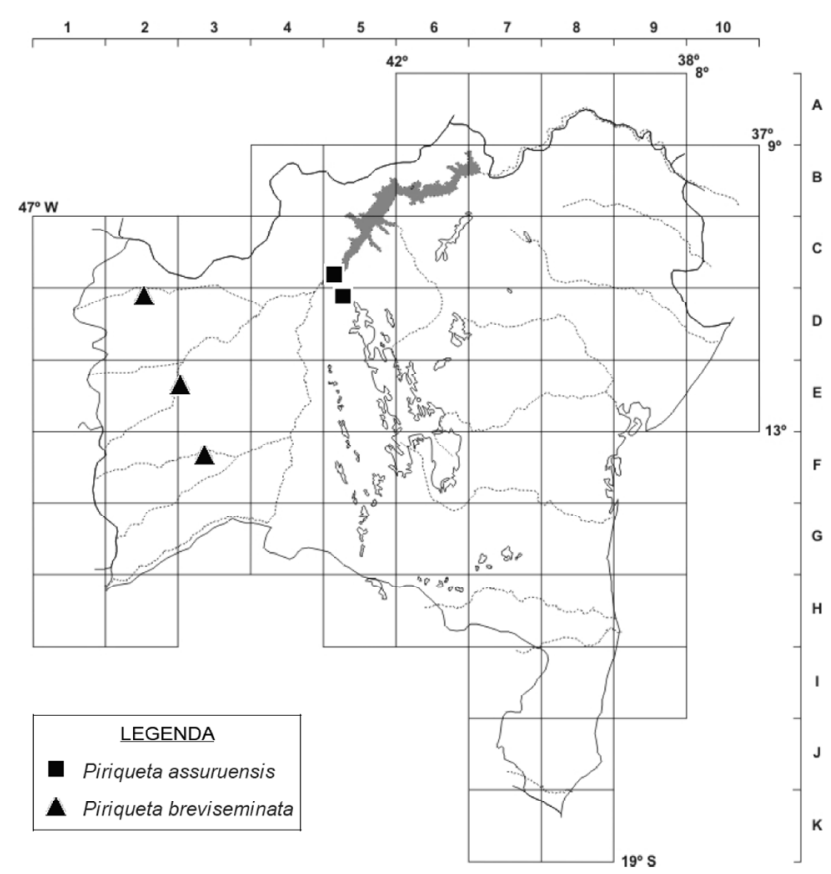

Figura 17. Distribuição de Piriqueta assuruensis e $P$. breviseminata no estado da Bahia.

\section{REFERÊNCIAS}

Arbo, M.M. 1993. Two new species of Piriqueta (Turneraceae) from Pico das Almas, Brazil. Kew Bulletin 48(1): 9-12.

Arbo, M.M. 1995. Turneraceae. Parte I, Piriqueta. Flora Neotropica Monograph 67: 1-156.

Arbo, M.M. 1997. Estudios sistemáticos en Turnera (Turneraceae). I. Series Salicifoliae y Stenodictyae. Bonplandia 9(3-4): 151-208.

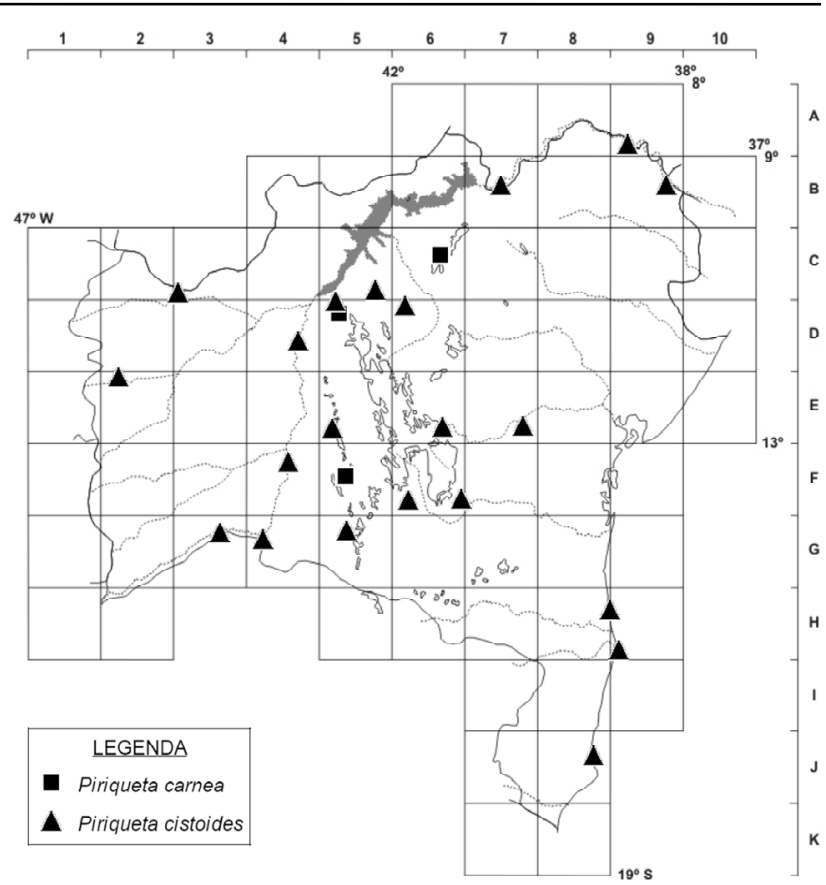

Figura 18. Distribuição de Piriqueta carnea e P. cistoides no estado da Bahia.

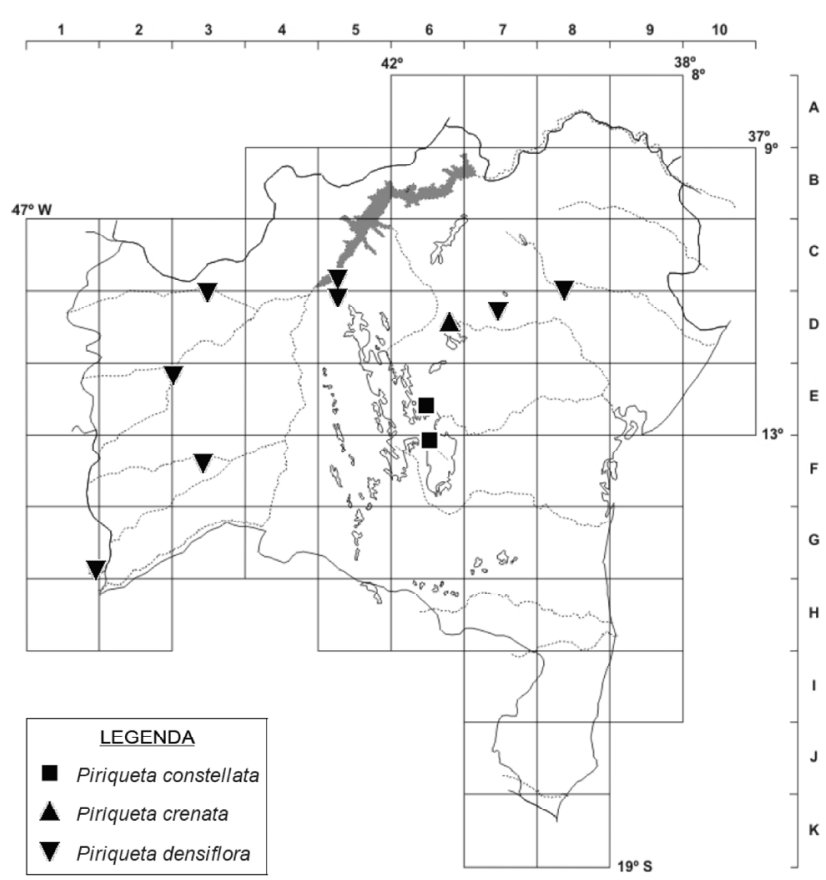

Figura 19. Distribuição de Piriqueta constellata, P. crenata e P. densiflora no estado da Bahia.

Arbo, M.M. 1999. Two new species of Piriqueta (Turneraceae) from Bahia, Brazil. Kew Bulletin 54(2): 459-464.

Arbo, M.M. 2000. Estudios sistemáticos en Turnera (Turneraceae). II. Series Annulares, Capitatae, Microphyllae y Papilliferae. Bonplandia 10(1-4): 1-82.

Arbo, M.M. 2005. Estudios sistemáticos en Turnera (Turneraceae). III. Series Anomalae y Turnera. Bonplandia 14(3-4): 115-318. 


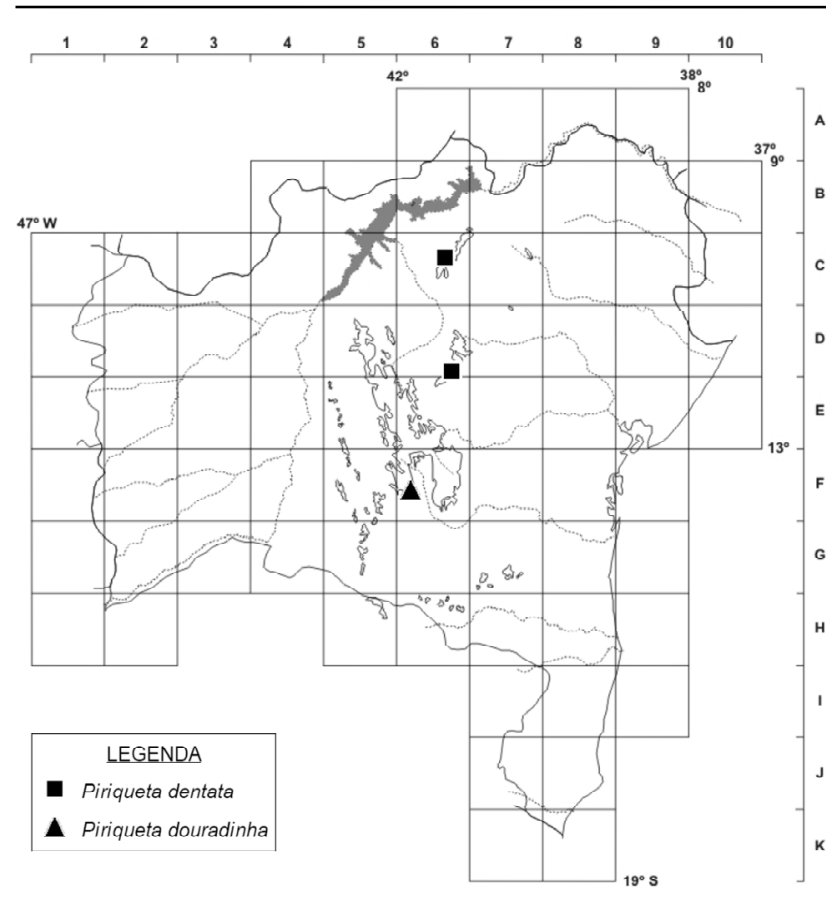

Figura 20. Distribuição de Piriqueta dentata e $P$. douradinha no estado da Bahia.

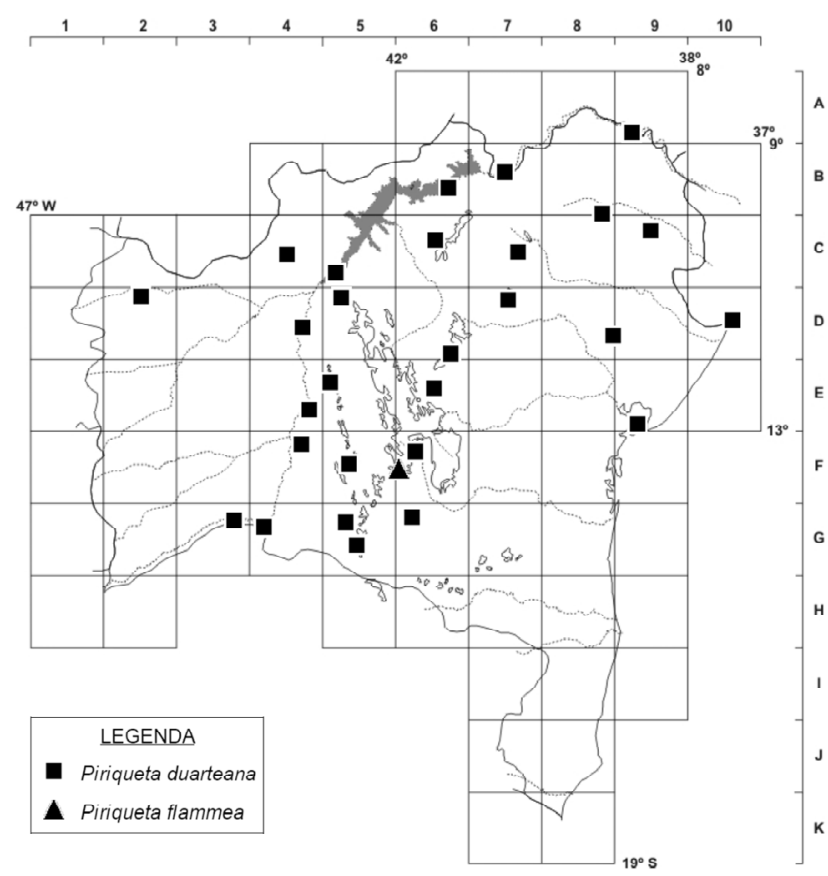

Figura 21. Distribuição de Piriqueta duarteana e P. flammea no estado da Bahia.

Arbo, M.M. 2007. Turneraceae. In: K. Kubitzki, J.B. Rhower, \& V. Bittrich (eds), The Families and Genera of Vascular Plants. Vol. 9. Springer Verlag, Heidelberg, p. 458-466.

Arbo, M.M. 2008. Estudios sistemáticos en Turnera (Turneraceae). IV. Series Leiocarpae, Conciliatae y Sessilifoliae. Bonplandia 17(2): 107-334.

Arbo, M.M. 2015. Turneraceae. In: Lista de Espécies da Flora do Brasil.. Instituto de Pesquisa Jardim Botânico do Rio de Janeiro. Rio de Janeiro. Disponível em http://floradobrasil.jbrj.gov.br/ja bot/floradobrasil/FB240; acesso em 4 dez. 2015.

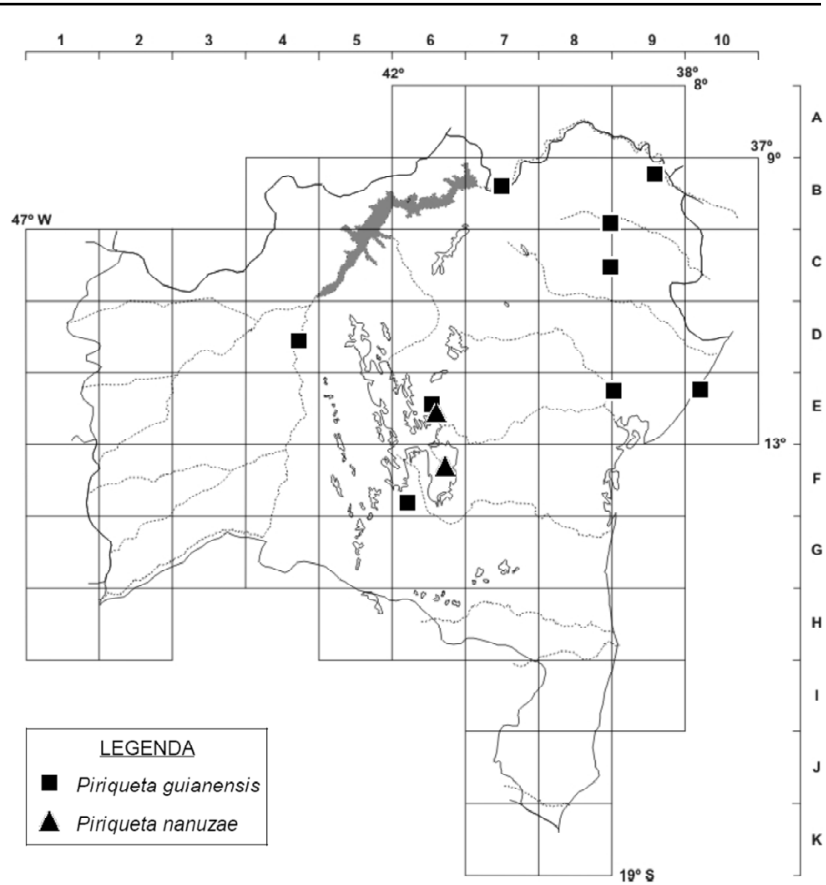

Figura 22. Distribuição de Piriqueta guianensis e P. nanuzae no estado da Bahia.

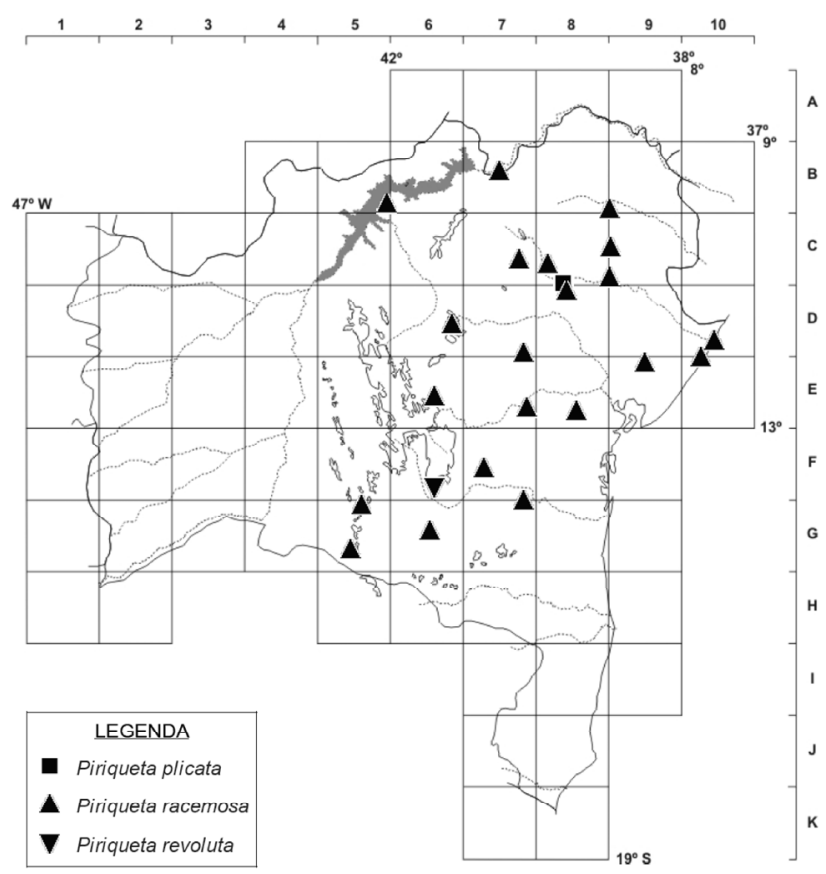

Figura 23. Distribuição de Piriqueta plicata, P. racemosa e $P$. revoluta no estado da Bahia.

Arbo, M.M. \& Fernández, A. 1987. Cruzamientos intra e interespecíficos en Turnera, serie Canaligerae. Bonplandia 6: 23-38.

Arbo, M.M. \& Giulietti, A.M. 2009. Turneraceae. In: A.M. Giulietti, A. Rapini, M.J.G. Andrade, L.P. Queiroz \& J.M.C. Silva (orgs). Plantas Raras do Brasil. Conservação Internacional (CI-Brasil), Belo Horizonte, p. 385-390.

Arbo, M.M. \& Mazza, S.M. 2011. The major diversity centre for neotropical Turneraceae. Systematics and Biodiversity 9: 203210 . 


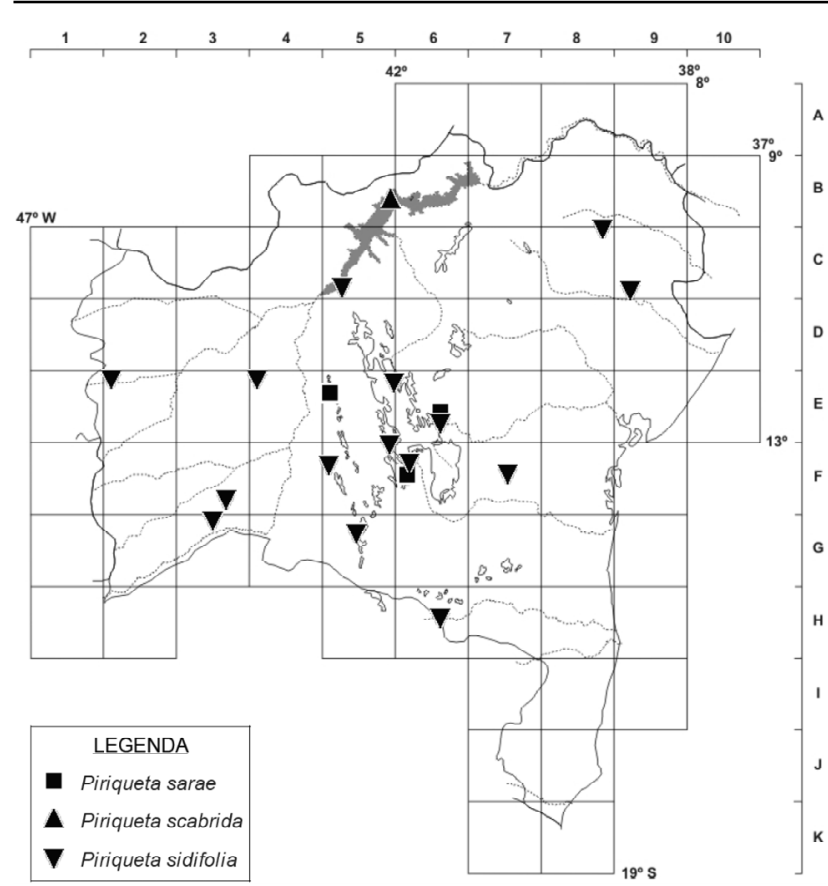

Figura 24. Distribuição de Piriqueta sarae, P. scabrida e $P$. sidifolia no estado da Bahia.

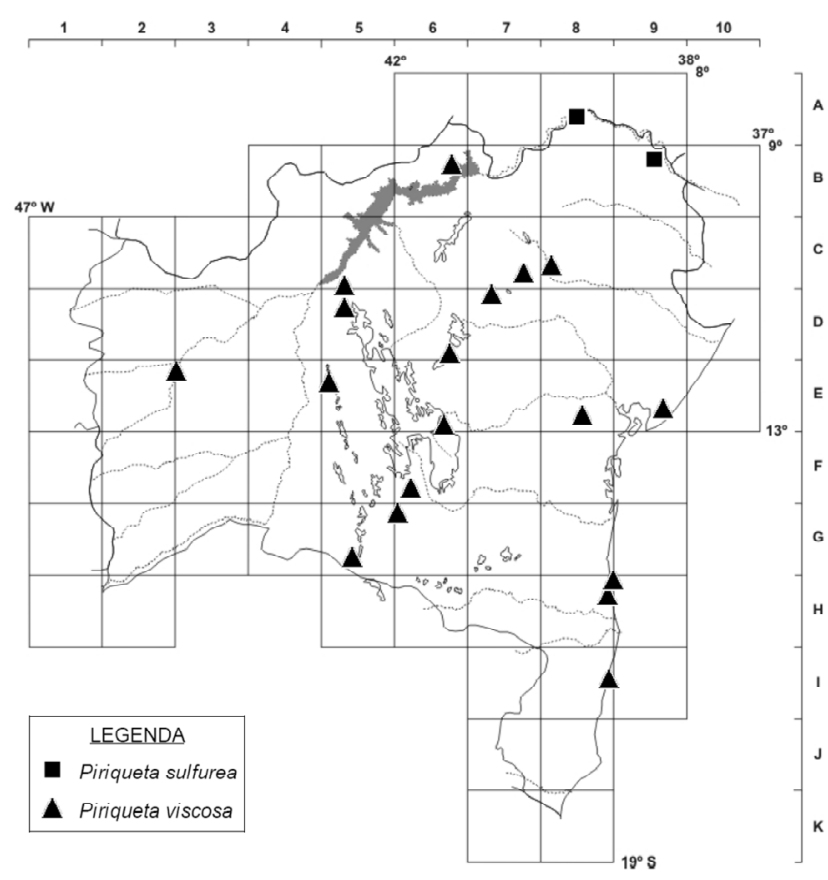

Figura 25. Distribuição de Piriqueta sulfurea e P. viscosa no estado da Bahia.

Brizicky, G.K. 1961. The genera of Turneraceae and Passifloraceae in the southeastern United States. Journal of Arnold Arboretum 42: 204-218.

Fernández, A. 1987. Estudios cromosómicos em Turnera y Piriqueta (Turneraceae). Bonplandia 6: 1-21.

Fernández, A. \& Arbo, M.M. 1989. Relaciones genômicas entre cuatro especies diploides de Turnera con flores amarillas (serie Canaligerae). Bonplandia 6: 93-109.

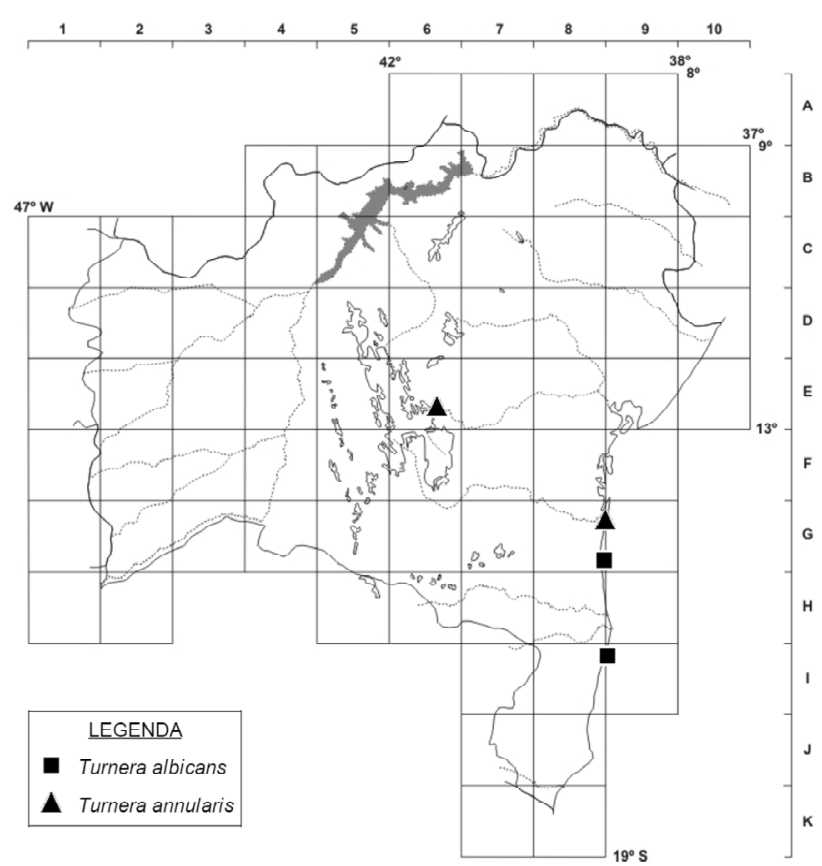

Figura 26. Distribuição de Turnera albicans e T. annularis no estado da Bahia.

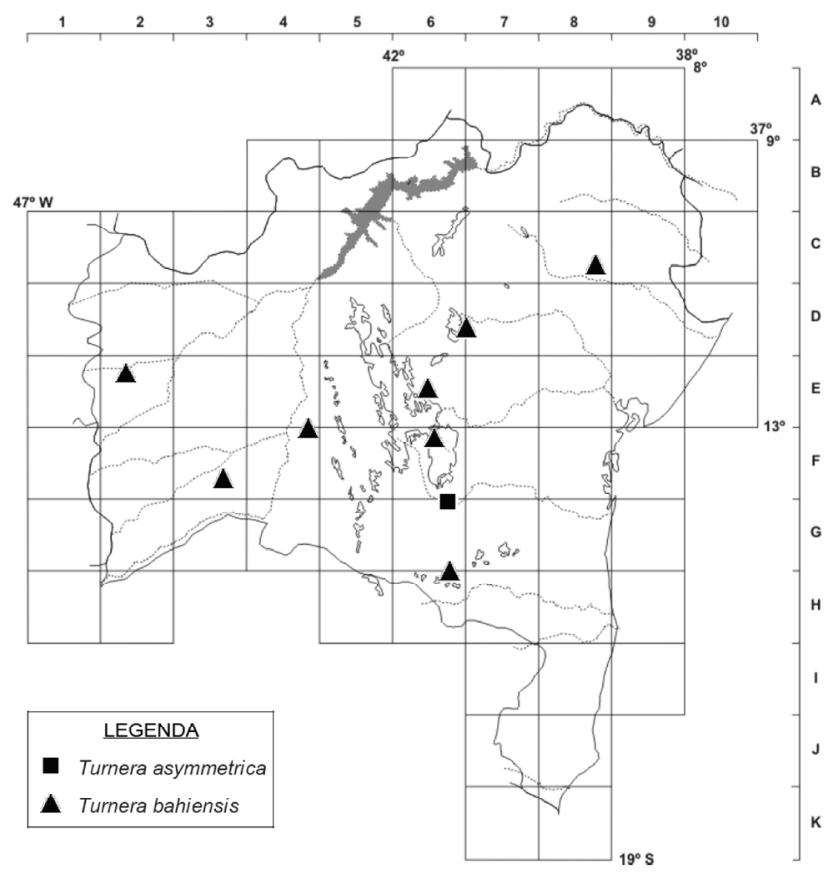

Figura 27. Distribuição de Turnera asymmetrica e T. bahiensis no estado da Bahia.

Fernández, A. \& Arbo, M.M. 1990. Gametas no reducidas y relaciones genómicas en tres especies de Turnera (Turneraceae). Darwiniana 30(1-4): 21-26.

Fernández, A. \& Arbo, M.M. 1996. Relaciones genómicas entre las especies diploides de flores blanco-azuladas de Turnera (serie Canaligerae). Bonplandia 9(1-2): 95-102.

Kumar, M.S.B. \& Vinesh, R. 2000. Turnera subulata J.E. Sm. (Turneraceae): a fast naturalizing weed in Indian subcontinent. Journal of Economic and Taxonomic Botany 24(2): 300-302. 


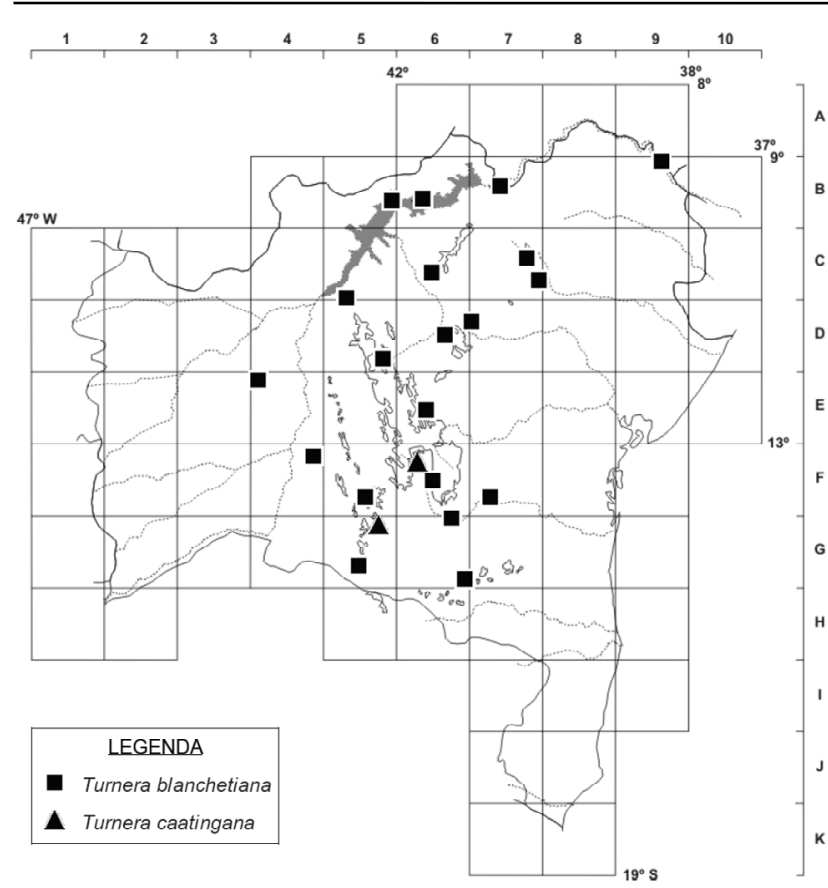

Figura 28. Distribuição de Turnera blanchetiana e T. caatingana no estado da Bahia.

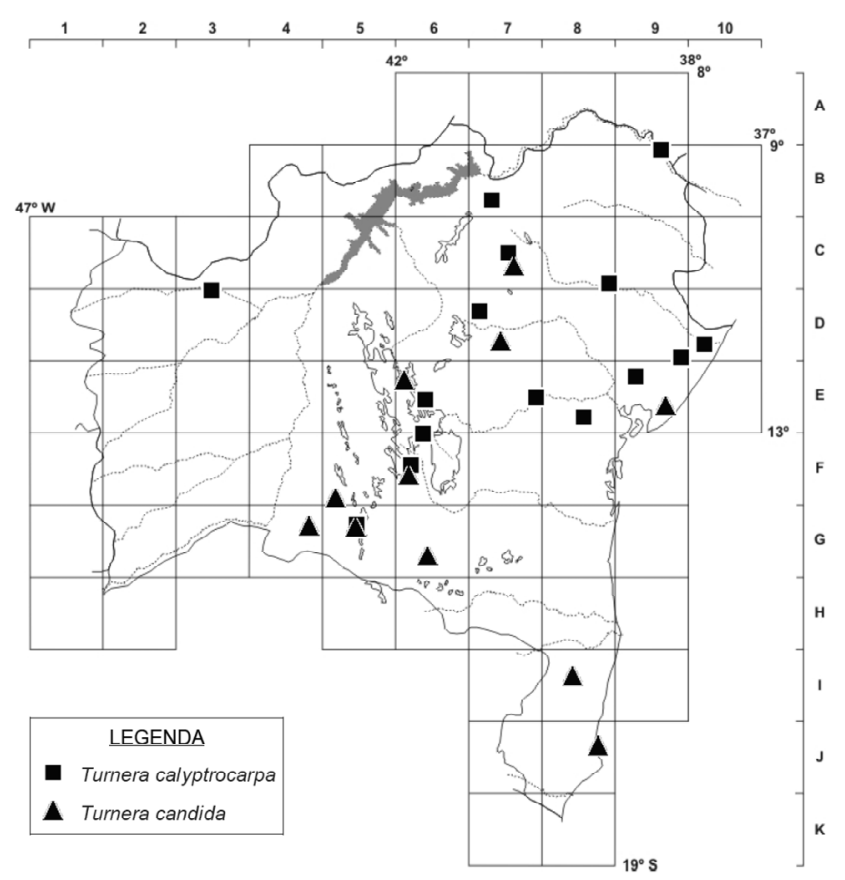

Figura 29. Distribuição de Turnera calyptrocarpa e T. candida no estado da Bahia.

Madhusoodanan, P.V. \& Rejani, A. 1989. Turnera subulata J.E. Smith (Turneraceae): an interesting exotic weed in Kerala. Journal of Economic and Taxonomic Botany 13(43): 128-132.

Medeiros, P.C.R. \& Schlindwein, C. 2003. Territórios de machos, acasalamento, distribuição e relação com plantas em Protomeliturga turnerae (Ducke, 1907) (Hymenoptera, Andrenidae). Revista Brasileira de Entomologia 47(4): 589-596.

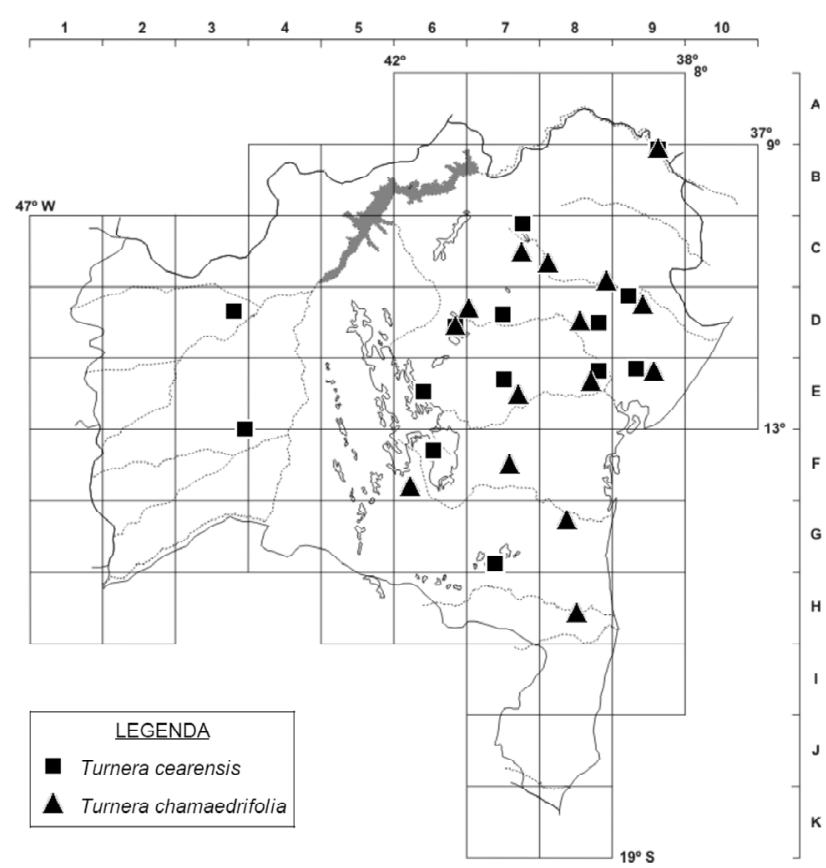

Figura 30. Distribuição de Turnera cearensis e T. chamaedrifolia no estado da Bahia.

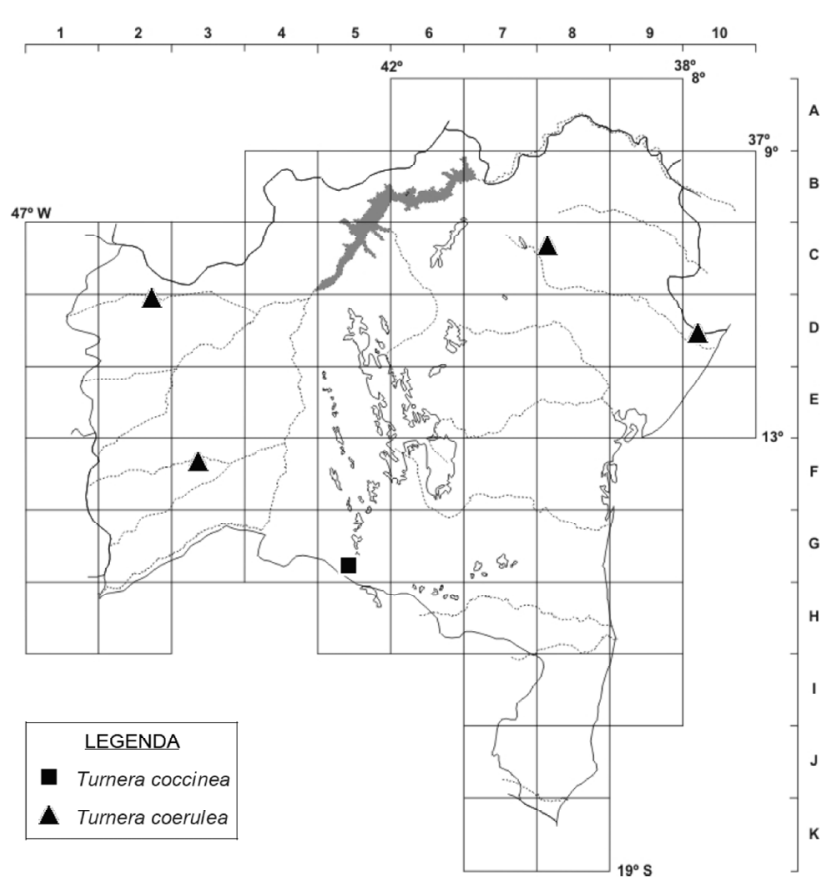

Figura 31. Distribuição de Turnera coccinea e $T$. coerulea no estado da Bahia.

Rocha, L \& Moreira, H.J.C. 2014. Turneraceae of Bahia, Brazil. Rapid Color Guide. The Field Museum, Chicago. Disponível em http://fm2.fieldmuseum.org/plantguides/guideimages.asp? $\mathrm{ID}=649$; acesso em 16 jan. 2015.

Rocha, L.; Arbo, M.M.; Souza, I.M. \& Rapini, A. 2014. Piriqueta crenata, a new species of Turneraceae (Passifloraceae s.l.) from the Chapada Diamantina, Bahia, Brazil. Phytotaxa 159(2): 105-110. 


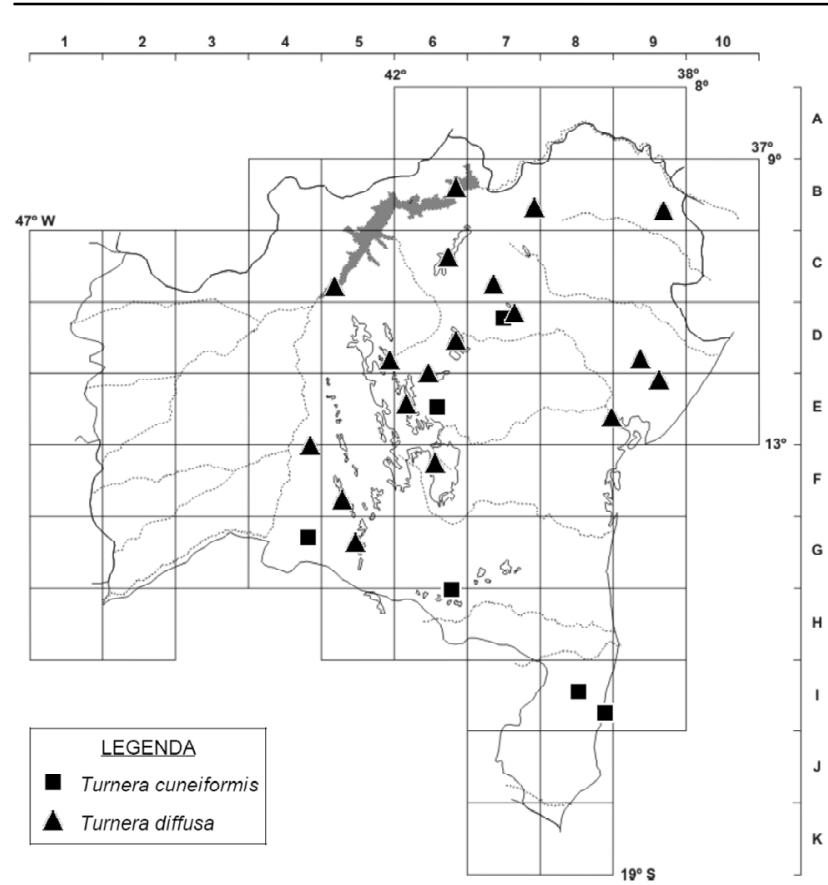

Figura 32. Distribuição de Turnera cuneiformis e T. diffusa no estado da Bahia.

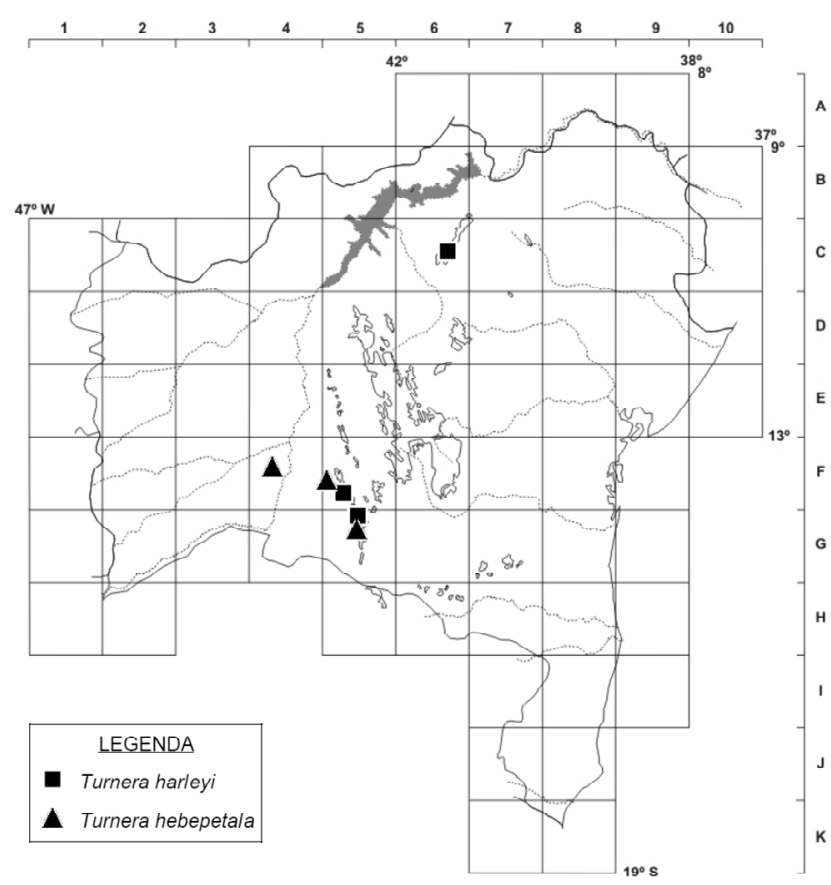

Figura 33. Distribuição de Turnera harleyi e T. hebepetala no estado da Bahia.

Spix, J.B. \& C.F.P. Martius. 1981. Viagem pelo Brasil 1817-1820. Editora Itatiaia, São Paulo.

Thulin, M.; Razafimandimbison, S.G.; Chafe, P.; Heidari, N.; Kool, A. \& Shore, J.S. 2012. Phylogeny of the Turneraceae clade (Passifloraceae s.1.): Trans-Atlantic disjunctions and two new genera in Africa. Taxon 61(2): 308-323.

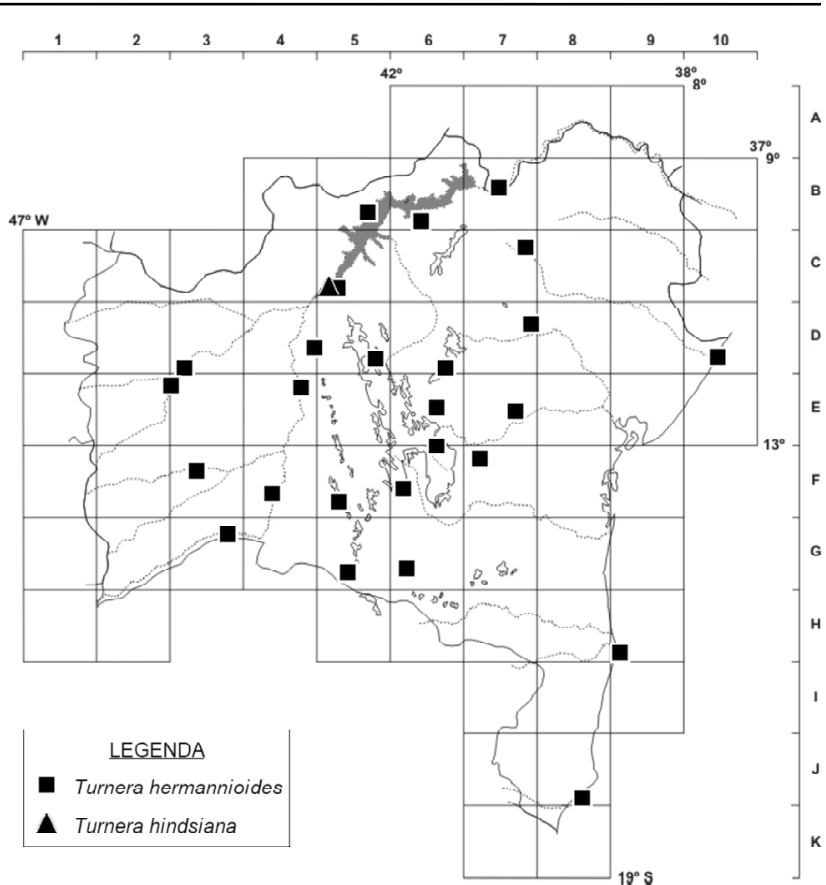

Figura 34. Distribuição de Turnera hermannioides e T. hindsiana no estado da Bahia.

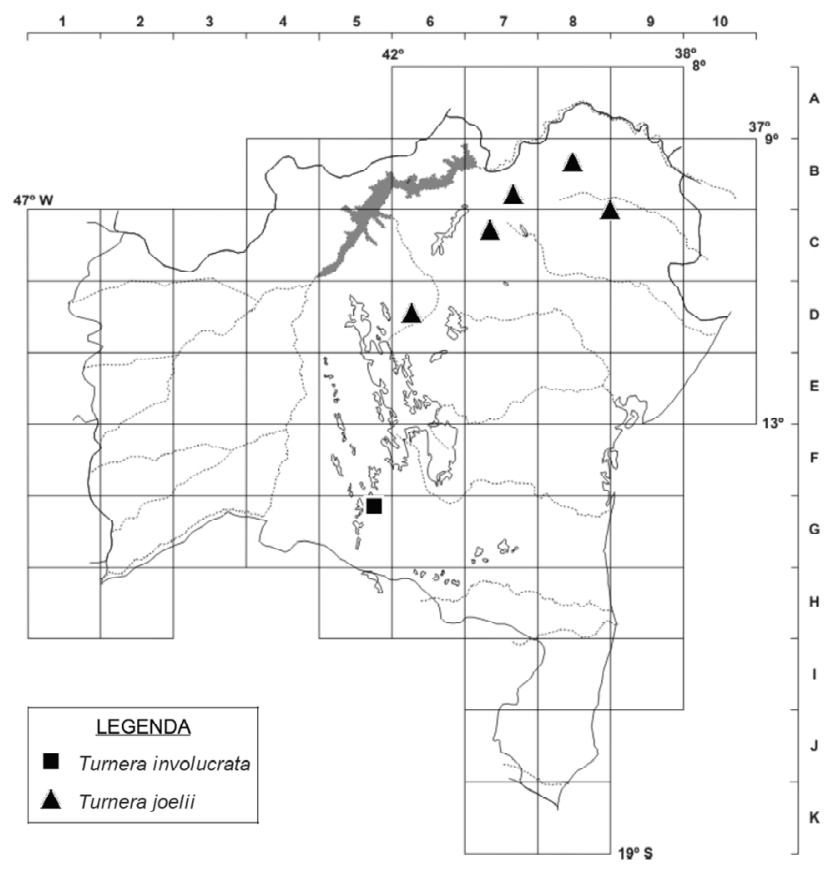

Figura 35. Distribuição de Turnera involucrata e T. joelii no estado da Bahia.

Urban, I. 1883. Monographie des Familie Turneraceen. Jahrbuch des Königlichen Botanischen Gartens und des Botanischen Museums zu Berlin 2: 1-152.

Urban, I. 1907. Turneraceae novae Uleanae. Repertorium Specierum Novarum Regni Vegetabilis 4: 134. 


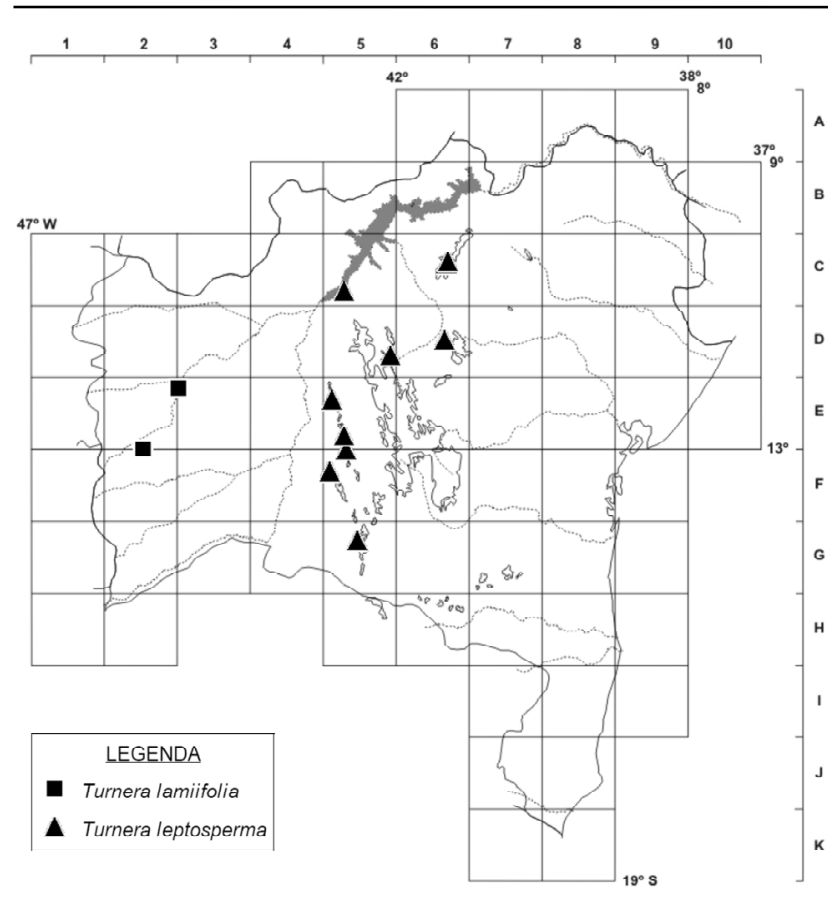

Figura 36. Distribuição de Turnera lamiifolia e T. leptosperma no estado da Bahia.

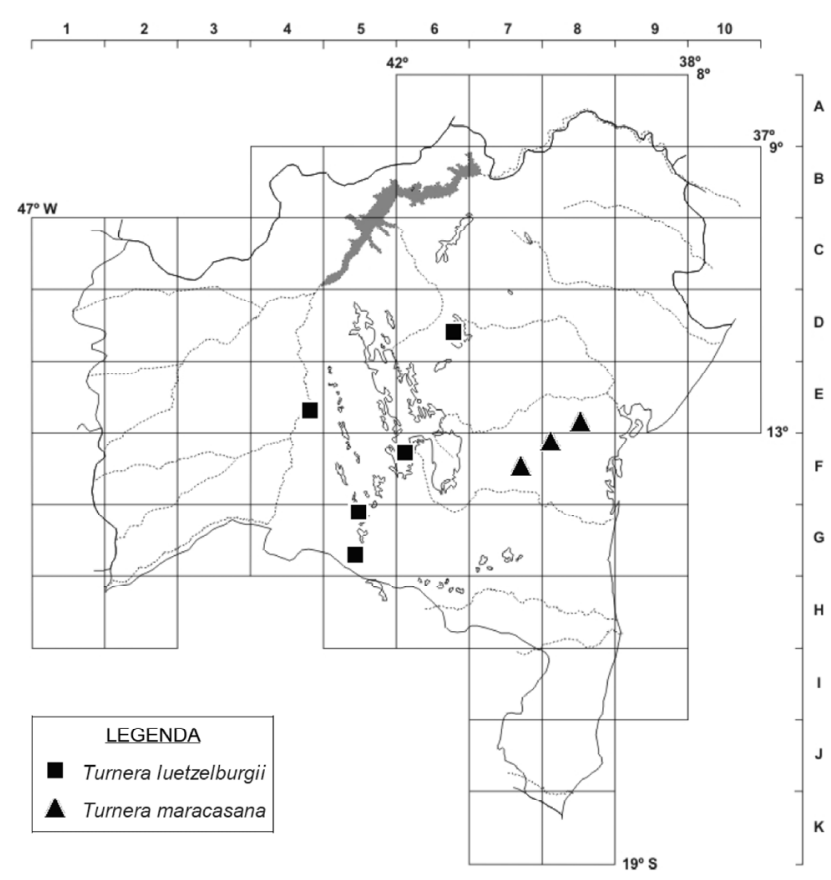

Figura 37. Distribuição de Turnera luetzelburgii e T. maracasana no estado da Bahia.

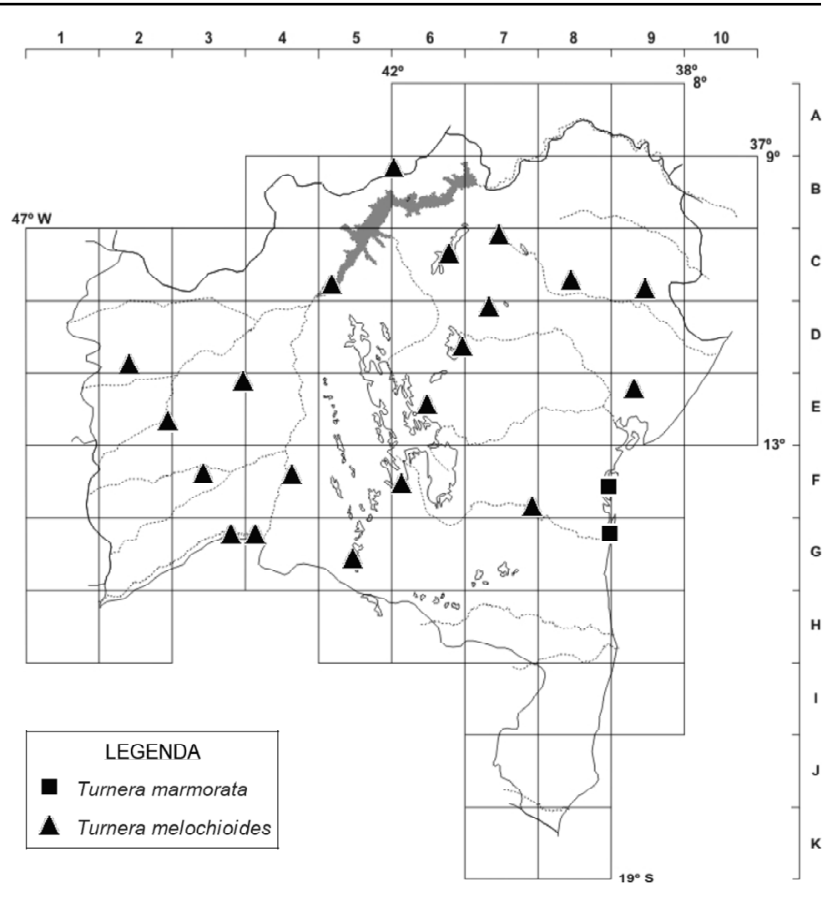

Figura 38. Distribuição de Turnera marmorata e T. melochioides no estado da Bahia.

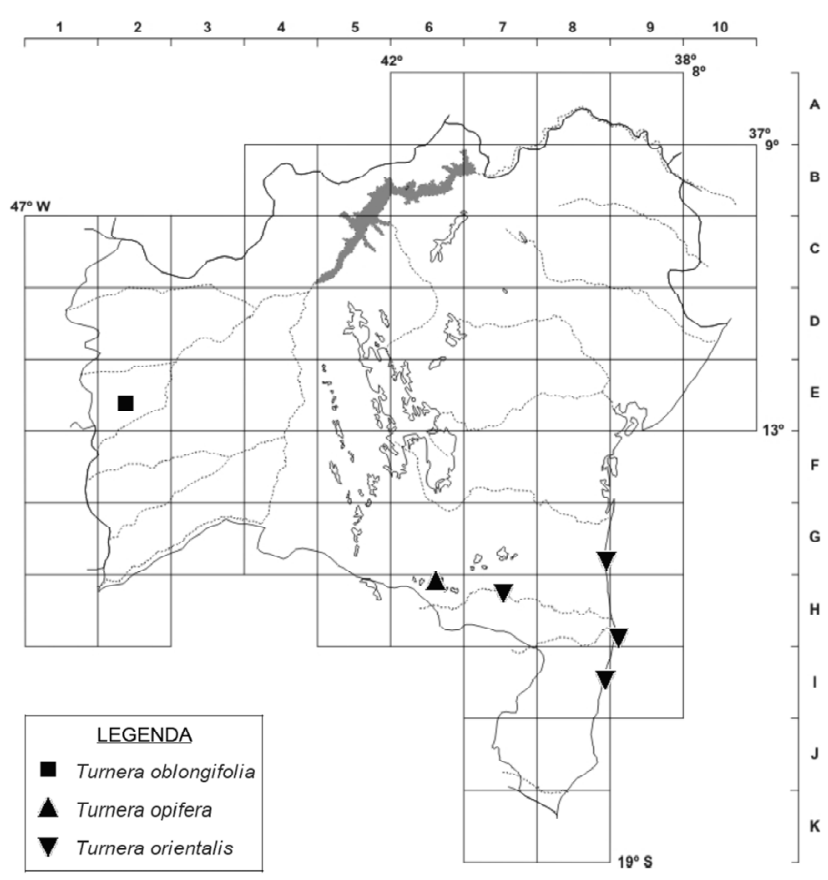

Figura 39. Distribuição de Turnera oblongifolia, T. opifera e $T$. orientalis no estado da Bahia.

\section{LiSTA DE EXSICATAS}

Abreu, I.S. 14 (1.1); Almeida, G.O. 9 (2.28), 194 (1.9), 723 (2.39); Alunos Bot. III t01 s.n. ALCB 67172 (1.23), s.n. CEPEC 107889 (2.8); Alves, A. 93 (2.10); Alves, M. 1108 (2.4), 1119 (2.8), 1172 (2.19), 1190 (2.28); Alves-Araújo, A. 918 (2.9); Amorim, A.M. 587 (1.21), 1050 (2.15), 2504 (2.31), 3028 (2.24), 3033 (1.9), 3041 (2.37), 3998 (2.25), 4001 (2.28), 6199 (2.15); Amorim, A.M.A. 1782 (2.19); Anderson, W.R. 36420 (2.19), 36565, 36852, 36894 (1.21), 36891 (2.29), 36895 (1.4), 37023 (1.6), 37102 (2.19); Andrade, I.M. 789 (2.10); Andrade-Lima, D. 74-6524 (2.28); Anjos, B.A. 151 (1.6); Antunes, J. 81 (2.19); Araújo, A.P. 415 (2.28); Araújo, D. 675 (1.3), 


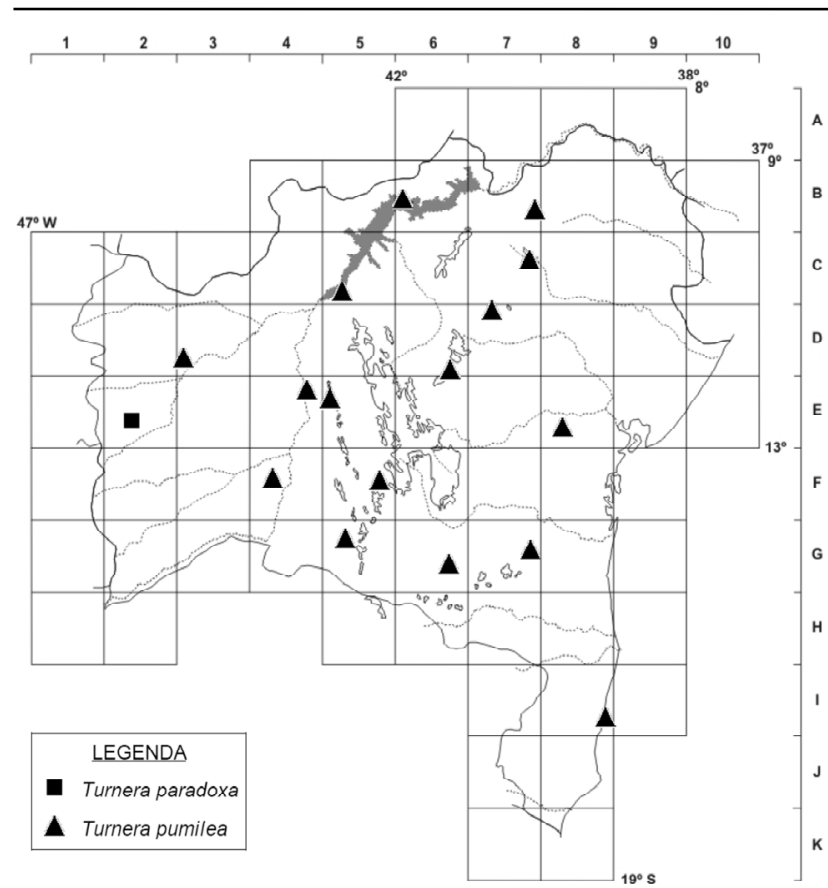

Figura 40. Distribuição de Turnera paradoxa e T. pumilea no estado da Bahia.

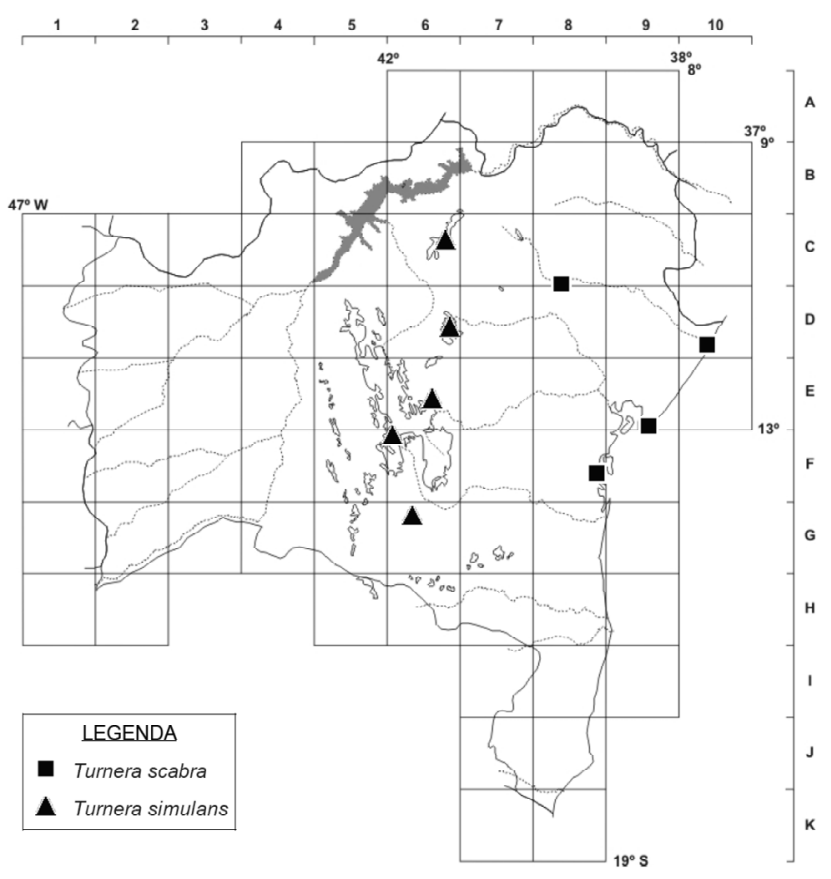

Figura 41. Distribuição de Turnera scabra e T. simulans no estado da Bahia.

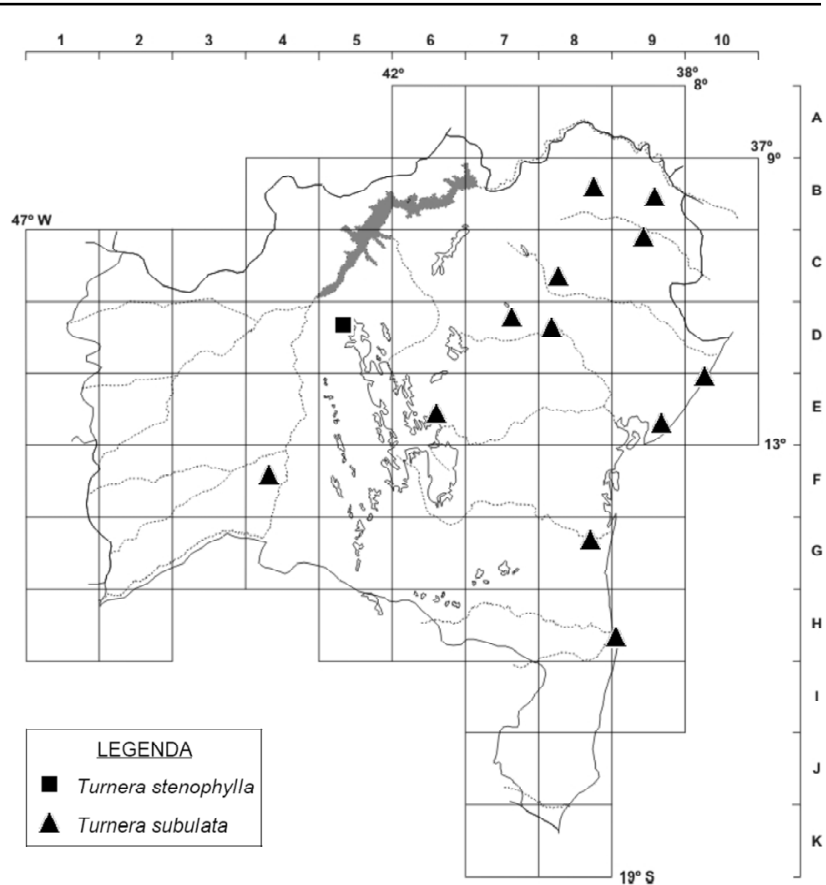

Figura 42. Distribuição de Turnera stenophylla e T. subulata no estado da Bahia.

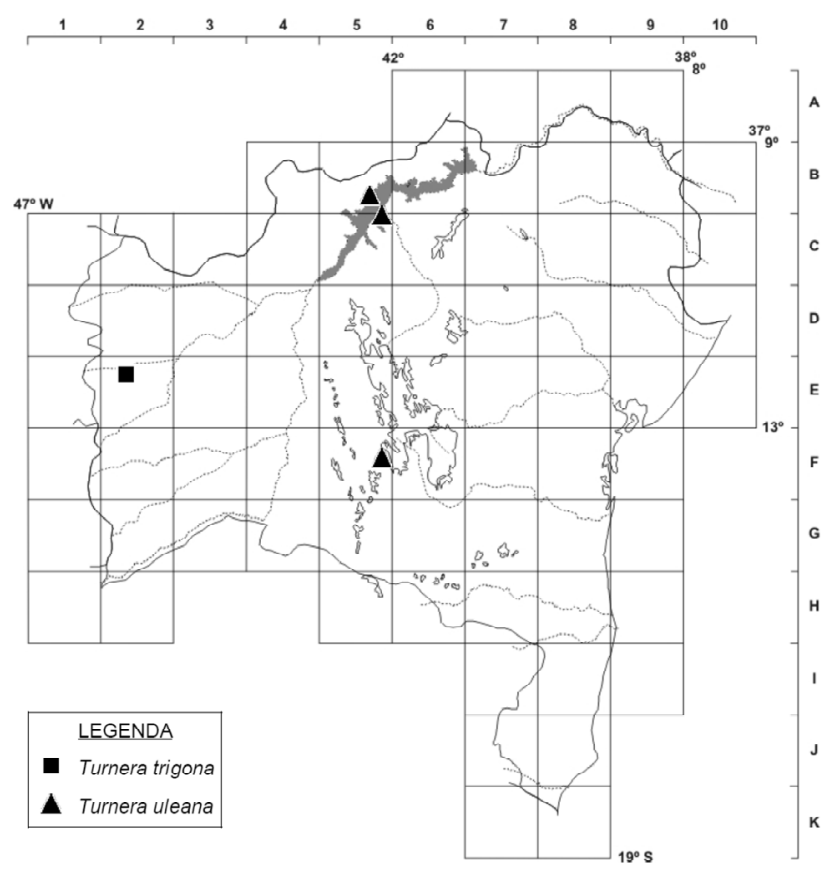

Figura 43. Distribuição de Turnera trigona e T. uleana no estado da Bahia.

685 (1.12), 1254 (2.5); Araújo, E.S. 14 (2.9); Arbo, M.M. 2538 (2.10), 2540 (1.15), 2541 (2.4), 5312 (1.12), 5319 (2.37), 5322 (1.9), 5330 (1.5), 5344 (2.24), 5347 (1.12), 5349 (2.22), 5354 (2.15), 5359 (1.10), 5361 (1.2), 5362 (2.4), 5363 (2.7), 5401 (2.15), 5407 (2.9), 5409 (2.25), 5417 (1.10), 5445 (2.10), 5448 (2.10), 5449 (2.14), 5453 (2.10), 5456 (2.33), 5458, (2.9), 5461 (2.10), 5463 (2.33), 5464 (1.23), 5486, 5503 (1.17), 5506 (2.7), 5507 (2.10), 5525 (2.28), 5526 (2.10), 5611 (2.33), 5612 (1.17), 5630 (2.24), 5634 (2.25), 5645 (2.6), 5649 (2.21), 5670 (1.17), 5680 (2.19), 5684 (2.25), 5694 (2.3), 5711,5743 (1.11), 5744 (2.25), 5753 (2.4), 5758 (2.15), 5761 (2.10), 5762 (2.19), 5763 (2.4), 5764 (2.8), 5765 (2.28), 5767 (1.15), 5775 (2.4), 5777 (2.9), 5783 (2.4), 5784 (2.8), 5785 (2.28), 5791 (2.19), 7217 (2.10), 7250 (1.17), 7251 (2.10), 7271 (1.17), 7272, 7284, 7296, 7315 (2.10), 7320 (1.17), 7321 (2.9), 7323, 7324 (2.5), 7325 (2.10), 7326 (2.9), 7332 (2.10), 7336 (1.23), 7338 (1.17), 7363 (2.15), 7365 (1.17), 7371 (2.10), 7372 (2.28), 7373 (2.19), 7386 (1.12), 7394 (2.15), 7395 (1.23), 7396 (2.28), 7398 (2.33), 7399 (2.19), 7421 (2.22), 7426 (2.33), 7427 (2.10), 7434, 7438 (2.5), 7440 (2.15), 7455 (2.15), 7456 (2.25), 7468 (1.10), 
7488 (2.37), 7489 (2.5), 7490 (1.9), 7523 (2.33), 7524 (1.23), 7528 (2.5), 7530 (2.19), 7531a (2.5), $7531 \mathrm{~b}(2.9), 7535$ (2.8), 7536 (2.28), 7549 (1.23), 7551 (2.4), 7561 (1.15), 7582 (1.21), 7583 (2.15), 7584 (2.10), 7585 (2.5), 7604 (1.19), 7605 (2.8), 7606 (2.19), 7607 (2.9), 7608 (2.15), 7610 (1.21), 7611 (1.17), 7613 (1.12), 7615 (2.19), 7625 (2.33), 7626 (1.23), 7641 (2.19), 7642 (2.21), 7643 (2.6), 7658 (2.19), 7659 (1.17), 7660 (2.5), 7688 (2.9), 7708 (2.26); Argolo, A.M. 4 (2.38); Arouck-Ferreira, J.D.C. 42 (2.15), 88 (1.12); Arraes, M.G. CFCR 6809 (2.15); Assis, J.A. 3 (1.14), 110 (1.4); Assis, J.S. 209 (2.37); Athayde, P.A. s.n. RB 109040 (2.10); Atkins, S. PCD 4881 (1.19), PCD 5754 (2.25); Bandeira, F.P. 171 (2.38), 236 (2.15); Baptista, H.P. PCD 312 (2.35); Barbosa, E. 2730 (2.9), 2743 (1.17), 2835 (2.28), 2871 (2.5), 2872 (2.15); Barreto, V. 1 (2.19), 213 (2.9), 241 (2.10), 246 (2.9); Bastos, B.C. 99 (2.10), 289 (2.5), 502 (2.10); Batista, M.A. 5 (1.12); Bautista, H.P. 366 (2.10), 461 (2.38), 925 (2.9), 950 (2.19), 1058 (2.4), 2240 (1.7), PCD 816 (2.8), PCD 3194, PCD 3625 (2.35), PCD 4380 (1.12), UMS 97 (1.15); Belem, R.P. 329 (2.9), 912, 1850, 2107, 2109 (2.27), 2830 (2.1), 3090 (2.27); Blanchet, J.S. 2708 (1.6), 2822 (1.3), 2841 (2.5), 2873 (2.36), 3097 (2.19), 3750 (1.12), 3832 (2.8), 3863 (2.7); Borba, E.L. 1872, 85250 (1.11); Bovini, M.G. 2492 (2.4), 2518 (1.7); Braga, D.V. s.n. IPA 73971 (1.17); Braga, N.M.P. 58 (1.12); Brandão, M.L.O. 1 (2.38); Brito, H.S. 83 (2.14); Brito, J.C. 20 (1.21), 61, 75 (2.35), 93 (1.23), 148 (1.19), 152 (2.35); Campos-Porto, P. 1343 (2.10), 2419 (2.19), 2451 (1.12); Carauta, J.P.P. 976 (2.19); Cardoso, D. 84, 1186, 1337, 1376 (2.10), 483 (1.17), 553 (2.7), 1190 (1.21), 1191 (2.15), 1220, 1444 (2.9), 1344 (1.17), 2015 (2.15), 2820 (2.35), 2829 (1.1), 2996 (1.2); Carneiro-Torres, D.S. 95 (2.28), 168 (1.1), 201 (2.4), 415 (2.10), 544 (2.15); Carvalho, A.M. 131 (2.28), 187, 215 (2.27), 538 (2.10), 881 (1.6), 1003 (2.4), 1063 (2.35), 1393 (2.27), 1554 (2.9), 1556 (1.21), 1586 (2.10), 1731 (2.17), 1733 (2.24), 1772, 1780 (2.15), 1850 (2.10), 1948 (2.9), 1976 (1.21), 2661 (2.19), 2756, 2815 (2.10), 2816, 2828 (2.15), 2831 (1.10), 2837 (2.9), 2841 (2.35), 2871 (1.5), 2885 (1.9), 2889 (2.37), 2916 (2.8), 3865 (2.10), 3895 (2.28), 6339 (2.8), 6345 (1.7), 6352 (2.9), 6383 (1.21), 6401 (2.35), 6420 (1.21), 6459 (1.19), 6636 (1.7), 6664, 7041 (2.35), 33153 (2.9), PCD 2183, PCD 962 (2.35); Carvalho, C.A.L. 8 (1.17), 52 (2.10), P-008 (1.17); Carvalho, D.N. 181 (2.9), 184 (2.10); Carvalho, P.D. 49 (1.14), 167 (2.33), 183 (2.19), 241 (1.12), 252 (2.27), 331 (1.12), 466 (1.17); Carvalho-Sobrinho, J.G. 677 (1.7), 2570 (1.2); Castellanos, A. 25081, 25392 (2.10), 25819 (2.33); Castro, M.S. 592 (2.4), s.n. ALCB 66386 (1.17), s.n. ALCB 66389 (1.14), s.n. ALCB 66393 (2.15), s.n. 66398 ALCB (1.21); Castro, R.M. 962 (1.7), 1270 (2.5); Cavalcanti, G. 15 (2.33), 64 (2.7); Cavalcanti, T.B. 1576 (2.39); Chamusca, C. 5 (2.38); Colaço, F.S. 147 (2.15); Colaço, M. 58,78 (1.14), 122 (2.15), 123 (1.14), 162 (2.7), 103 (2.9), s.n. ALCB 66389 (1.14); Conceição, A.A. 93 (1.12), 135 (2.35), 262 (2.19), 269 (2.8), 1553 (2.15), 1588 (1.12), 1602 (2.9), 1819 (1.7), 2676 (1.6), 2780 (1.21), 2963 (1.23), 3035 (2.15), 3214, 3307 (1.12), 4110 (2.25); Conceição, A.S. 34 (2.38), 120 (2.34), 133 (1.17), 580, 649 (1.1), 954 (1.14), 1184 (2.10); Conceição, S.F. 100 (2.35), 101 (2.25), 300 (2.10), 318 (1.12), 107 (1.10); Coradin, L. 6066 (2.15), 6142 (2.10), 6216 (2.15), 6279 (2.37), 6628 (2.28); Cordeiro, J. 3682 (2.10), 3688 , 3762 (2.9), 3835 (1.12), 3840, 4330 (2.10); Correia, C. 240 (2.22), 356 (2.5), 357 (1.17), 401 (2.5), 456 (2.33); Côrtes, A.L. 59 (2.4), 61 (1.21); Costa, A.L. 909 (2.10), s.n. ALCB 2835 (1.6), s.n. ALCB 2836, s.n. ALCB 2837, s.n. ALCB 2838 (1.17), s.n. ALCB 2841 (2.19), s.n. ALCB 2844 (2.33), s.n. ALCB 2846 (2.38), s.n. ALCB 2851 (2.15), s.n. ALCB 2852 (2.22), s.n. ALCB 9035 (2.10), s.n. ALCB 9036 (2.35), s.n. ALCB 95198 (2.4); Costa, C. 39 (2.38); Costa, C.A. 4 (2.26); Costa, G. 30 (1.15), 198 (1.23), 220 (2.35); Costa, J.A.S. 70 (2.38), 204 (1.17), 1454 (2.38); Costa, J.M. 173 (1.16); Couto, A.P.L. 150 (1.21), 218 (2.4); Crepaldi, I. 1, 2 (1.14); Damascena, L. 85 (2.15); Davidse, G. 11745 (2.15); Davis, P.H. 61044 (2.10); Duarte, A.P. 6630 (2.33), 6793 (1.23), 9352 (2.4); Duarte, L. 352 (2.10); Eiten, G. 10874 (2.22); Esteves, G. 2343 (2.28), 2374 (1.21), 2520 (1.12), 2521 (1.10), 2522 (2.19); Eupunino, A. 517 (2.14); Faria, J.E.Q. 559 (2.8); Félix, L.P. 6780 (1.15), 7504 (1.19), 7557 (2.28), 9569 (1.19); Fernandes, M. 3 (2.38); Ferreira, F.M. 1721 , 1840 (2.26); Ferreira, J.D.C.A. 42 (2.15); Ferreira, J.L. 285 (2.33), 306 (2.7); Ferreira, M.C. 151 (1.12), 265 (1.14); Ferreira, V.S. 68 (1.21), 69 (2.35); Ferrucci, M.S. 981 (2.17), 982 (2.24), 994 (2.38), 995, 996 (2.28), 1019 (2.14), 1023 (2.19), 1106 (2.10), 983a (2.25); Fiaschi, P. 2092 (2.27), 2487 (2.17); Fonseca, M.L. 2679 (1.9); Fonseca, M.R. 1288 (1.12); Fonseca, W.N. 374 (2.22), 404 (2.15); Forzza, R.C. 1263 (1.12), 1287 (1.2); Fotius, G. 3673, 3682a (2.9), 3682b (2.22), 3822 (1.23), 3853 (2.22); Fraga, C.N. 2626 (2.19); França, F. 1302 (1.1), 1579 (2.15), 1982 (2.10), 1989 (1.17), 2134 (2.7), 2332 (2.10), 2408 (2.7), 2421 (2.9), 2422 (2.7), 2837 (1.10), 2841 (2.15), 3135 (1.2), 3840 (1.21), 3909 (2.2), 3973 (2.4), 4049 (2.4), 4110 (1.21), 4120 (1.10), 4323 (2.25), 4973 (1.17), 5134 (2.7), 5299 (2.15), 5402 (2.9), 5625 (1.6), 5683 (2.22), 4325 (2.25); Freire, L. 101 (1.17); Freire-Fierro, A. 1671, 1694 (2.35), 1783 (2.37), 1788 (1.3), 1899, 1900 (1.6), 1929 (1.9); Freitas, M. 4 (1.10); Funch, L.S. 1123a (2.5), 1123b (2.4); Funch, R. 120 (2.38), 129, 465 (1.15), 724 (2.8), 775 (2.35), FCD 57 (2.4), FCD 88 (1.12), s.n. HUEFS 40705 (2.38); Furlan, A. CFCR 238 (2.19), CFCR 327 (1.9), CFCR 328 (2.37), CFCR 366 (1.3), CFCR 367 (1.5), CFCR 1597 (1.15); Ganev, W. 105 (1.1), 245 (1.7), 629 (1.1), 780 (2.15), 857 (1.11), 1341 (2.15), 1498 (2.35), 1783 (2.25), 2581 (2.9), 3175 (1.1), 3308 (1.18), 3344 (1.1), 3486 (1.7); Gentry, A. 49983, 49984 (1.17); Gil, E. 6 (2.38); Gildo, P. s.n. ALCB 2847 (2.38); Ginzbarg, S. 808 (2.5); Giulietti, A.M. 1548, 1548 (1.19), 1623 (2.35), 1707 (2.10), 1731 (1.14), 1747 (2.15), 1762 (2.22), 1895 (2.8), 2192 (1.1), 2377 (2.35), 2385 (1.18), 53925 (2.22), CFCR 1285 (1.11), CFCR 1286 (2.25), PCD 2267 (1.10), PCD 2961 (1.12), PCD 2962 (1.12), PCD 5500 (1.17), CFCR 6862 (1.19), CFCR 6770 (2.35); Gomes, F.S. 96 (2.15), 97 (2.5), 147 (1.21), 148 (2.24), 479 (1.7), 346 (2.22), 839 (2.7); 861 (1.14), 879 (2.10); Gonçalves, L.M.C. 83 (2.28), 213 (2.17); Gonçalves, R.S. 31 (2.9); Gonçalves-Barros, M.J. 22 (2.19); Gonzaga, L.P. 17, 42 (1.12); Gottsberger, G.K. 15-28173 (2.10), 11-4273 (2.22); Groppo Jr., M. 1050 (1.23); Grupo Pedra do Cavalo 19 (2.10), 37 (1.17), 163, 384 (2.10); Guedes, M.L. 290 (2.38), 474/356 (2.15), 1016 (2.15), 3824 (2.8), 4058 (2.10), 4842 (2.38), 4958 (2.35), 4985 (2.8), 5467 (2.19), 6210 (1.7), 7214 (2.9), 7219 (2.15), 7358 (2.7), 7852 (1.14), 7872 (1.12), 7964 (2.15), 8325 (2.10), 9830 (2.35), 9870 (1.10), 10310 (2.24), 10328 (2.15), 10670 (2.10), 10679 (1.6), 10722 (1.10), 10873 (1.23), 10973 (2.15), 10974 (1.10), 11067 (1.21), 11171 (1.17), 11549 (1.12), 12095 (1.17), 12140 (2.38), 12632 (2.27), 12692, 13356 (2.19), 13489 (2.19), 13490 (1.12), 13583 (2.28), 13884 (1.23), 13962 (1.6), 14112 (1.12), 14172 (2.9), 14189 (1.12), 14197 (2.35), 14350, 14352 (2.15), 14391 (1.21), 14513 (2.8), 14514 (2.15), 14762 (1.23), 14782 (2.10), 14844 (2.15), 15007 (1.12), 15153 (2.35), 16048 (1.12), 16243 (1.14), 16261 (1.12), 16317 (1.11), 16341 , 16662 (2.15), 16846 (2.5), 16876 (2.9), 17118 (2.15), 17837 (2.10), 18986 (1.13), 19251 (2.9), 19300 (1.17), 19302 (2.15), PCD 3027 (2.37), PCD 3088 (1.9), PCD 5807 (2.4), s.n. CEPEC 72597 (2.10), s.n. ALCB 26854 (2.10); Gusmão, E.F. 216 (2.10), s.n. ALCB 19344 (1.17); Harley, R.M. 15059 (2.28), 15139 (1.19), 15144 (1.21), 15145 (2.9), 15262 (2.15), 15429 (1.13), 15524 (2.25), 15618 (2.19), 15637 (2.4), 
15779 (2.4), 15827, 15849 (2.25), 16053 (2.35), 16164 (2.9), 16165 (2.10), 16296 (1.17), 16402 (2.10), 16682 (1.5), 16698 (1.12), 16715 (2.15), 16807 (2.17), 16814 (2.24), 16862 (1.2), 16944 (1.10), 16956 (2.17), 17430 (1.6), 17433 (2.19), 17602 (2.27), 18468, 18550 (2.27), 18605 (2.28), 18620 (1.23), 18677 (2.4), 18790 (2.35), 18938 (2.15), 18970 (1.23), 18994 (2.24), 18996 (2.37), 19020 (1.9), 19034 (1.3), 19052 (1.5), 19094 (1.6), 19157 (2.15), 19158 (2.24), 19291 (2.28), 19293,19294 (2.19), 19300 (1.10), 19322 (2.15), 19445 (2.7), 19452 (2.9), 19511 (1.13), 19892 (2.8), 19932 (1.19), 19934 (2.35), 20032 (2.19), 20150 (2.35), 20715 (2.4), 20792 (2.25), 20793 (2.25), 20838 (2.35), 21127 (2.17), 21185, 21201 (2.15), 21209 (1.21), 21210 (2.15), 21443 (1.6), 21790 (1.21), 22060 (2.27), 22394 (2.35), 22430 (2.8), 22677 (2.35), 22901 (2.35), 22941 (1.2), 22955 (2.15), 24265 (1.12), 24350 (2.9), 24381 (1.13), 24649 (1.7), 24650 (2.25), 25354 (2.25), 25375 (2.8), 25798 (1.13), 25832 (2.35), 25906 (1.19), 25953 (2.35), 26024 (1.19), 26047 (1.21), 26048 (1.7), 26453 (2.15), 26902 (2.4), 26903 (1.21), 27030 (1.21), 27092 (1.21), 27093 (1.7), 27094 (2.35), 27095 (1.21), 27145 (2.5), 27568 (2.40), 27724 (2.7), 28113 (1.14), 28469 (2.10), 50177, 50417 (2.35), 50418 (2.25), 50419 (1.1), 50674 (2.25), 50685 (2.35), 52748 (2.25), 53463 (2.5), 53491,53553 (2.9), 53740 (2.28), 53898 (1.4), 53901 (2.28), 54420 (2.35), 54638 (1.7), 54714 (2.7), 54755 (2.9), 54875 (2.28), 54908 (2.22), $54910(2.9), 54911$ (2.8), 54968 (2.8), 55020 (2.28), 55524 (1.19), 55906 (2.9), 56174 (1.19), 17430a (1.6), 55601 (2.9), 55756 (1.6), 55778 (2.13), 55940 (2.28), 55957 (2.13), 56170 (2.35), 56193 (1.6), CFCR 14049 (2.35), CFCR 14150 (2.8), CFCR 14304, CFCR 14305, CFCR 7204 (2.35), H 50672 (1.7), PCD 2930 (1.6), PCD 3771 (1.12), PCD 4431 (2.35), PCD 4449, (1.19), PCD 4470 (2.35), 50535, 50675 (1.1); Hatschbach, G. 39473 (2.28), 39515 (2.33), 39583 (2.15), 42035 (2.23), 42078 (2.28), 42098 (2.19), 44143 (1.21), 44187 (1.21), 44221 (2.19), 44230 (2.22), 44234 (2.15), 44252, 45052 (2.10), 45115 (1.6), 46380 (2.19), 46554 (2.35), 47352 (2.30), 47391 (1.21), 47402 (2.35), 47426 (1.19), 47435 (1.7), 47440, 47460 (2.8), 47755 (2.19), 48041 (2.25), 48048 (1.7), 48072 (1.6), 48184 (2.10), 50077 (2.5), 50501 (1.21), 53365 (2.35), 53386 (1.19), 53417 (1.21), 53420 (2.35), 53440 (1.19), 55126 (2.5), 55140 (2.18), 56556 (2.33), 56558 (1.21), 56572 (2.19), 56583a (1.6), $56583 \mathrm{~b}$ (1.12), 56591 (2.38), 56602 (2.33), 56611 (2.18), 56625 (2.19), 56626 (2.14), 56627 (1.21), 56634 (2.15), 56641a (2.8), 56641b (1.17), 56642a (2.17), 56642b (2.28), 56643 (2.19), $56647 \mathrm{~b}(2.33), 56658$ (2.19), 56662 (2.8), 56665 (2.35), 56668, 56675, 56685 (2.19), 56711 (1.19), 56712 (2.25), 56713 (2.8), 56723 (1.21), 56724 (2.8), 56725 (2.28), 56728, 56732 (2.19), 56733 (2.25), 56734 (2.8), 56744 (1.21), 56753 (1.7), 56755 (1.7), 56758, 56766 (2.25), 56767 (2.28), 56783 (2.35), 56784 (1.7), 56785, 56792 (2.8), 56793 (2.35), 56797 (1.19), 56804 (1.21), 56813b (1.11), 56824 (2.35), 56825 (2.8), 56825b (2.25), 56825c (1.7), 56826 (2.19), 56840 (2.19), 56846 (2.15), 56850 (1.7), 56851 (2.10), 56861 (2.28), 56863 (2.35), 56876 (2.15), 56877 (2.4), 56888 (1.7), 56903 (2.35), 56904 (2.28), 56910 (2.4), 56925 (2.28), 56926 (2.19), 56929 (1.12), 56934 (1.17), 56963a (2.4), 56963b (2.8), 56964 (2.28), 56965a (2.8), 56981 (1.6), 56982 (2.10), 61908 (2.19), 61914 (1.21), 61956 (2.8), 62022 (2.28), 63052 (2.8), 63095 (2.10), 63156 (2.13), 65044 (2.19), 65059 (2.18), 65099a (2.33), 65099b (1.23), 65103 (1.21), 65137 (2.15), 65163 (2.33), 65170 (2.19), 65797 (1.23), 65805 (1.6), 65850 (2.15), 65933 (1.21), 65966 (2.4), 66028 (2.8), 66043 (2.19), 67578 (1.6), 67584 (2.28), 67611 (2.24), 67643 (1.21), 67728 (2.24), 67732 (1.21), 67757 (1.6), 67767,67770 (2.19), 67773 (2.15), 67798 (2.24), 67823 (1.12), 67838 (2.25), 67851 (2.33), 67854 (1.19), 67858 (2.25), 67875 (2.8), 67903 (2.35), 67907 (1.7), 67909 (2.35), 68516 (2.34), 71237 (1.21), 71270 (1.6), 71274 (2.19), 71278 (1.12), 75456, 75539 (2.10), 75567 (2.34), 75778 (1.6), 75823 (1.17), 75842 (2.10), 77940 (1.21), 78570 (1.21), 78582 (2.15), 78586 (2.24), 78631 (1.21), 78678 (2.5), 78727 (1.6), 78758 (1.17); Heringer, E.P. 358 (2.5); Hind, D.J.N. 50905 (2.25), PCD 4058 (2.35), PCD 4250 (1.19); Ibrahim, M. 34 (2.15); Ichreiner s.n. R 37589 (1.17); s.n. R 91292, R 91293 (2.10); s.n. R 91250 (2.33); Irwin, H.S. 14685 (1.4), 14797 (2.13), 14896 (2.28), 30732 (2.7), 30983 (2.4), 31196 (2.15), 31248,31476 (2.4), 31344 (2.19), $31354 b$ (2.32.), 31483 (2.19), 32331 , 32449 (2.15), 32480 (2.35); Jardim, J.G. 759 (2.28), 1032 (2.2), 1185 (2.35), 1189 (2.8), 1220 (1.17), 1783 (2.2), 2159 (1.23), 2317 (2.28), 2318 (2.8), 2518 (2.35), 2555 (2.9), 2582 (1.13), 2588 (2.8), 2638, 2793 (2.27), 2799 (2.10), 3313 (2.28), 3408 (1.6), 3478 (1.6), 3540 (1.12), 3553 (2.28), 3566 (1.12), 3592 (1.6), 3657 (1.21), 3675 (2.28), 4632 (2.1), 4931 (2.27); Jesus, A.R. 16 (2.10), 23 (2.22); Jesus, N.G. 845 (2.28), 1626 (1.17), 1650 (2.19), 1865 (2.10), PC 102 (2.15); Jost, T. 303 (1.17), 576 (2.37); Junqueira, M.E.R. 6 (2.10); Krapovickas, A. 10088 (1.17), 10091 (2.5), 10097 (2.9), 12807 (2.15), 29999 (1.21), 30165a (1.21), 30165b (2.28), 30178 (2.13), 30182 (2.13), 37876 (1.21), 37877, 37879 (2.28), 37891 (2.19), 37932,38606 (2.33), 38693 (1.4), 38695 (2.28), 38702 (2.19), 38713 (2.28), 38793 (2.22), 38805 (2.10), 38807 (1.17), 38816 (2.14); Labouriau, L.G. 914 (2.5); Leite, K.R.B. 97 (2.15), 192 (2.9), 202 (2.10), 224 (2.26); Lemos, M.J.S. 19 (1.17), 47 (2.7), 116 (2.35); Lewis, G.P. 1980 (1.19), CFCR 6811 (2.25), CFCR 6999 (2.7); Lima, J.L.S. 77 (2.8); Lima, L.C.L. PC 160 (2.15); Lôbo, C.M.B. 6 (1.14), 20 (1.23), 52 (2.35); Löfgren, A. 940 (2.19), 990 (2.15); Loizeau 522 (2.5); Lordêlo, R.P. 56-70, 56-284 (1.17), 56-294, 56-433 (2.10), 56-600 (1.14), 57-20 (2.19), 57-366 (2.22), 57-736 (2.19), 58-19 (2.7); Loureiro, D.M. 208 (2.34); Lucchese, A.M. 3 (2.7); Luceño, M. 410 (1.19); Luetzelburg, P. 186, 189 (2.25), 397 (2.11); Lyra-Lemos, R.P. 1837 (2.4); Macedo, G.E.L. 16 (2.26); Machado, M. 230 (2.35), 170 (2.15); Machado, R.F. 108 (2.10), 158 (2.9), 191, 192 (2.33), 215 (2.22), 107 (2.9), 424, 520 (2.10); Maciel, J.R. 734 (2.19), 1166 (2.8); Magalhaes, M. 912 (2.27); Maio, S. 1160 (2.25); Martinelli, G. 5316,5344 (2.4), Martius, C.F.P. s.n. M (2.29), s.n. M 113098 (1.16), s.n. M 113148, s.n. M 113150 (2.28), s.n. M 0210494 (2.13), s.n. M 0214549 (2.16); Mascarenhas, J.A. 6 (1.14); Matos, E. 3472 (2.27); Matos, M.L.S. 3 (2.10); Mattos-Silva, L.A. 247 (1.21), 763 (2.8), 1268 (2.27), 1414, 2912 (2.1); Melo-Silva, R. 760 (2.12); 800 (1.21), 2138, 2150 (2.35), 2796 (1.21), 2814 (1.2), 2829 (1.12), 2832 (2.10); Melo, A. 253 (2.15), 272 (2.5), 286 (2.7); Melo, E. 463, 488, 1068 (2.10), 1405 (2.10), 1413, 1458, 1958 (2.7), 2830 (2.15), 2851, 3210 (2.26), 3362 (2.4), 3610 (2.7), 3612 (2.5), 3883 (1.17), 3922 (2.7), 3963 (2.10), 4312, 4322 (2.7), 4396 (2.9), 4447 (1.23), 4941 (1.8), 4952 (2.35), 5131 (1.2), 5247 (2.24), 5398 (1.6), 5400 (2.19), 5437 (2.10), 5500, 5520 (2.5), 6236, 6276 (2.10), 6638, 7305 (2.15), 7341 (1.23), 7388 (2.19), 7470 (1.12), 7471 (2.28), 7479 (1.21), 7503 (2.15), 7508 (1.21), 7530, 7623 (2.5), 7638 (1.21), 7649, 7653 (2.5), 7671 (2.19), 7951 (2.15), 8121, 8210, 8261 (2.28), 8263 (1.21), 8497 (1.17), 8506 (2.35), 8967 (1.6), 9665 (2.4), 9005 (1.6), 9409 (2.22), 10004 (2.4), PCD 1329 (2.35), PCD 1361 (1.15); Melo, M.R.F. 336 (1.6); Mendes, K. 186 (2.7); Mendes, M.S. 671 (2.17); Mendes, M.R.A. 324 (1.22); Mendes, P.T. s.n. R 101568 (2.28); Mendonça, R.C. 1413 (2.28), 3291 (1.4), 4261 (1.9); Menezes, N.L. 1280 (1.12), 1281 (2.28), s.n. CTES 202864 (2.8); Miranda 30 (2.37); Miranda, A.M. 4293 (2.10), 5823 (2.19), 6452 (2.5); Miranda, C.A. 261 (1.6), 341 (1.5); Miranda, E.B. 179 (2.9), 592 (2.19), 821 (1.14), 822 (2.15), 836 (1.14), 949 (2.15); Miranda, M. 82 (1.12); Monteiro, V.M. 52 (1.17); Moraes, A.o. 98, 127 (2.15), 165 (2.24), 171 (1.10), 203 (2.15); Moraes, M.V. 
634 (2.38); Mori, S.A. 9671 (2.19), 10924 (2.1), 11467 (2.27), 11774 (2.26), 12461 (1.13), 12651 (2.35), 12927 (2.4), 13316 (2.35), 13465 (2.15), 13582 (1.13), 14299 (2.35); Moruz, C.V.A. 154 (2.33); Nascimento, A.F.S., 88 (2.10); Nascimento, C.B. 64 (1.12); Nepomuceno, C.F. 2 (2.10); Netto, L. s.n. R 91223 (2.31); Neves, S.P.S. 66, 110 (2.28), 123 (2.35), 133 (1.15), 177 (2.35), 288 (2.28), 289 (1.21); NicLughadha, E. PCD 6063 (2.15); Noblick, L.R. 1203 (2.4), 1376 (2.10), 1626 (1.23), 1646 (2.10), 1668 (1.23), 1672 (2.10), 1794 (2.28), 1795 (2.8), 1854 (2.10), 2537 (1.17), 2643 (1.14), 2644 (1.23), 2678 (2.33), 2868 (1.15), 2908 (2.4), 3148 (2.19), 3175 (2.10), 3413 (2.9), 3464a (1.6), 3464b (2.19), 3496 (1.10), 3611 (2.9), 3705 (1.17), 3779 (2.15), 4100 (2.38), 4301 (1.17), 2035 (2.10), 2452 (1.23), 2476, 3127, 4094, 4145, 4353 (2.10); Nunes, E. s.n. CTES 53648 (2.11); Nunes, T.S. 112 (1.1), 502,553 (2.19), 574 (2.9), 979 (2.37), 1318 (2.8), 1339 (2.10), 1462 (2.35), 1613 (1.12), 1615 (1.21), 1657 (2.5); Oliveira, A.A. 132 (1.2), 192 (1.14), 259 (1.1); Oliveira, E.L.P.G. 386 (1.17), 521 (2.10); Oliveira, F.C.A. 908 (1.4); Oliveira, H.C. s.n. HUEFS 45323 (2.10); Oliveira, I. 41 (1.6); Oliveira, M. 2551 (2.15), 3267 (2.13), 4114 (1.23), 4202 (2.37), 4713 (1.2), 4765 (2.15), 4770 (1.2); Oliveira, M. 2440, 2471 (1.22), 2848 (1.12); Oliveira, M.V.M. 699 (2.15); Oliveira, P.P. 91 (1.6); Oliveira, R.P. 153 (2.8), 295 (2.10), 312 (1.17), 501 (2.13); Oliveira-Filho, L.C. 132 (2.19), 141 (2.5), 151 (1.17); Orlandi, R.P. 258(1.12), 274 (2.19), 399, 566, 826, 827, 843 (1.12), 845 (2.19), PCD 427, PCD 520, PCD 649 (2.35); Paschoaletti, L.F.G. SE 5 (1.21), 7 (2.28); Passos, L. PCD 4849, (1.7) PCD 5035 (1.23), PDC 5711 (2.15); Pastore, J.F.B. 2056 (2.35), 2082 (1.8); PaulaSouza, J. 4785 (2.35), 4870 (1.10), 4877 (2.15), 4930, 4961 (1.10), 4964 (2.19), 4966 (2.8), 4969 (2.28), 4974 (2.8), 5017 (2.28), 5018 (1.12), 5051 (2.9), 5060 (2.19), 5166 (1.14), 5199 (1.6), 5205 (1.23), 5207 (1.6), 5251 (2.9), 5264 (2.35), 5268 (2.15), 5289 (2.35), 5292 (1.7), 5385 (1.21), 5417 (1.17), 5475 (1.6), 5520 (2.10); Pereira, A.C. 25 (1.17), PCD 1867 (1.12), PCD 1877 (2.4); Pereira, E. 1988 (2.10), 2005 (2.4), 2150 (2.15), 6505/8494, 9605/8494 (2.27), 10090/9180 (2.35), 10065/9352 (2.4); Pesqueira, U.S. 69 (1.12); Pickersgill, B. Ru72-87 (2.22); Pinheiro, R.S. 399, 1178 (2.31), 2139 (1.12); Pinto, G.C.P. 20/80 (2.7), 43-83 (2.28), 56-35 (2.10), 147/83 (1.17), 211/81 (1.6), 219/83 (2.22), 394/83a (2.4), 408a/83 (2.35), 1068, 42300 (2.10), 42269 (2.28), 42321 (2.15), s.n. ALCB 2845 (2.37), s.n. ALCB 6722 (1.23), s.n. IPA 21897 (2.4); Pinto, J.A.L. 10 (1.14); Pirani, J.R. 5422 (2.15), 5423 (2.35), CFCR 472 (2.5), CFCR 7447, CFCR 7498 (1.12), H 51428 (1.21), H 51430b (2.9), H 51430a (2.25); Pontes, T.A. 15 (2.9); Pontual, I. 78 (2.15), $68-730$ (2.22); Popovkin, A.V. 460 (2.7); Poveda, A. PCD 682 (2.28); Prata, A.P. 1836 (2.19), 2146 (2.28); Prates, A.R. 50, 113 (2.10); Proença, C. 305 (1.21); Queiroz, E.P. 4816 (2.23); Queiroz, L.P. 63 (2.5), 351 (1.14), 379 (2.7), 568 (2.15), 1041 (2.9), 1150 (2.34), 1479 (2.7), 1482 (2.10), 2592 (1.14), 2600 (2.10), 2611 (2.6), 3093 (2.10), 4548 (2.15), 4791 (1.12), 4806 (2.15), 4814 (2.28), 4822 (2.15), 4851 (2.20), 4876 (2.28), 4946 (2.9), 5128 (2.24), 5153 (1.5), 5237 (2.17), 5302 (2.15), 5343 (2.24), 5373 (1.2), 5374 (2.24), 5378 (2.28), 5456 (1.12), 5749,5751 (1.6), 5778 (1.12), 5858 (2.19), 5863 (2.28), 5900 (1.6), 6039 (1.9), 6041 (2.28), 6577 (2.19), 6601 (2.40), 7057 (2.10), 7143 (1.19), 7185 (2.15), 7334 (2.10), 7435 (2.35), 7881 (2.19), 8045 (2.19), 8059 (2.15), 9119 (2.5), 9132 (1.23), 9131 (1.23), 9209 (2.33), 9645 (1.12), 9922 (2.9), 10855 , 10934 (1.12), 12164 (2.37), 13282 (1.10), 13612 (2.28), 13614 (2.19), 13616 (2.8), 13670 (2.10), 13672 (2.9), 13678 (2.15), 13960 (2.5), 13962 (2.9), 14380 (2.24), 14426 (2.28), 14458 (1.4), 14496 (1.4), 14594 (2.8), 14672 (2.15), 14676 (1.12); Raimundo, S.P. 1178 (2.31); Ramos, A.M.C. s.n. ALCB 26218 (2.10); Rapini, A. 979 (2.35), 1010 (1.12), 1503 (2.5); Rebouças, R. 1 (2.9); Rego, Nei de Sá s.n. ALCB 95199 (2.38); Ribeiro, P.G. 19 (2.28); Ribeiro, R.C. 27 (1.21), 5a (1.14); Ribeiro, T. 290 (2.30); Ribeiro, W. s.n. SP 329797 (2.19); Ribeiro-Filho, A.A. 172 (2.10); Riedel, L. 743; Rigueira, D. s.n. ALCB 74679 (2.9); Rocha, L. 352 (2.19), 353 (1.21), 354 (2.8), 355 (1.23), 356 (1.7), 357 (1.15), 358 (2.28), 359 (2.15), 360 (2.9), 361 (2.28), 362 (2.19), 363 (2.8), 364 (1.6), 365 (2.10), 366 (2.9), 367 (2.19), 368 (2.8), 369 (1.7), 370 (2.28), 371 (2.15), 372 (1.23), 373 (2.14), 374 (1.12), 375 (1.17), 376 (2.10), 377 (2.14), 378 (2.15), 379 (2.28), 380 (2.35), 381 (1.10), 382 (2.28), 383 (2.33), 384 (1.23), 385 (2.15), 386 (1.12), 387, 388 (2.10), 389 (2.33), 390 (1.17), 391 (2.21), 392 (1.21), 393 (2.28), 394 (2.33), 395 (2.15), 396 (1.21), 397 (2.12), 398 (1.23), 399 (2.19), 400 (2.8), 401 (1.21), 402 (2.8), 403 (2.28), 405 (1.17), 406 (2.25), 407 (2.19), 408 (2.10), 409 (2.33), 410 (1.17), 411 (2.5), 412 (2.9), 413 (1.21), 414 (2.9), 417 (2.38), 418 (2.14), 419 (1.17), 420 (1.17), 421 (2.28), 422 (2.19), 423 (2.28), 424 (1.12), 425 (1.23), 426 (2.15), 427 (1.21), 428 (2.17), 429 (2.24), 430 (2.17), 431 (2.9), 432 (1.21), 433 (2.8), 434 (1.12), 435, 436 (1.21), 438 (1.4), 439 (2.19), 441 (2.28), 449 (1.6), 450 (1.21), 453 (1.23), 454 (1.21), 455 (1.9), 456 (1.4), 461 (1.9), 463 (1.4), 464 (2.28), 468 (1.9), 469 (1.21), 473 (1.21), 474 (1.21), 475 (1.4), 477 (1.21), 480 (2.28), 481 (1.4), 482 (1.9), 483 (2.7), 484 (2.19), 489 (2.28), 494 (1.12), 495 (2.28); Rocha, P. 42 (1.12); Rodarte, A.T. 36 (2.15), 51 (1.12), 65 (2.28), 106 (1.6), 113 , 114 (1.12), 130 (2.28); Rodrigues, L. 20 (1.10); Rodrigues, M.O.S. 10 (1.14), 12 (2.38); Rodrigues, M.T.U. s.n. SPF 81444 (1.12); Roque, N. 631, 737 (1.12), 2447, 2492, 2637, 2672 (2.9), 2885 (1.1), 3565 (2.12), CFCR 14945 (1.21), CFCR 14948, CFCR 14960 (2.7), CFCR 14968 (2.8), CFCR 15024 (1.21), s.n. ALCB 67787 (2.15); Rosas, E. 17 (2.10); Sá, C.P.O. 26, 43 (2.28); Saar, E. PCD 4785 (2.8), PCD 5100 (2.10), PCD 5456 (2.28); Salgado-Odilon, A. 262 (2.5), 321 (2.19), 343 (1.6), 369 (2.5), 373 (2.15); Salimena, F.R.G. 367 (2.4); Sampaio, S. 33 (2.10); Sano, P.T. CFCR 14521 (1.7), CFCR 14522 (2.35), CFCR 14549 (1.1), CFCR 14677 (2.35), CFCR 14854 (2.25); Santana, D.L. 710 (1.21); Santana, S.C. 1298 (2.27); Sant'Ana, S.C. 487, 515 (2.15), 518 (1.12), 662 (2.38); Santos, A.K.A. 561 (2.18), 578 (2.8); Santos, B.T.C. 491 (2.39); Santos, E. 2007 (2.10); Santos, E.B. 229 (2.27); Santos, F.S. 101 (2.33); Santos, G.M.M. 1 (2.38); Santos, J.O. 35 (1.17); Santos, J.S. 7 (2.10); Santos, R.B. 54 (1.13); Santos, R.S. s.n. HB 28042 (2.10); Santos, T.S. 804 (2.31), 1282 (2.1), 2169, 2196, 2887 (2.27), 3449 (2.10), 3508 (2.33), 3513 (2.5); Santos, V.J. 465, 502 (2.10), 582 (2.15); Schreiner s.n. R 91250 (2.33); Senna, L.R. 110 (2.28); Sessegolo 251, 283 (2.15); Silva, B.M. 15 (2.37); Silva, F.H.M. 320, 467, (1.21), 352 (2.15), 363 (2.28), 396 (1.14), 409 (2.28), 470, 502 (2.15), 509 (2.28); Silva, F.O. 68 (2.38); Silva, F.S. 2 (2.10); Silva, G.O.M. 24 (1.6); Silva, G.P. 3110, 3115,3180 (1.4); Silva, J.S. 519, 539 (2.19), 594 (2.22), 643 (2.9); Silva, L.B. 39 (2.38); Silva, M. 7 (1.17); Silva, M.A. 3559 (1.4), 3584 (1.12); Silva, M.M. 134 (2.35), 153 (1.19), 467 (2.37); Silva, P. s.n. SP 39350 (1.12); Silva, R.F.S. 241 (2.10), 246 (2.9); Silva, S.B. 272 (1.14); Silva, U.C.S. 14 (2.5), 18 (2.24), 19 (1.21), 25 (1.5), 167 (2.10); Silva-Castro, M.M. 1043 (1.7), 1054 (2.8), 1058 (2.24), 1060 (2.24), 1061 (1.21), 1062 (2.15); Siqueira-Filho, J.A. 1715 (2.17), 1777 (2.24); Soares, P.S. 1 (2.10); Sobral, M. 5888 (2.5); Soeiro, R. 07-96 (1.14), 23-96 (2.10); Sousa, L.A. 209 (2.9), 220 (2.10); Souza, E.B. 1119, 1571 (2.15); Souza, E.R. 237 (1.17); Souza, I.M. 27 (1.14), 139 (2.38), 141 (1.14); Souza, M.H.C. 3 (2.19); Souza, P. s.n. ALCB 19684 (1.17), Souza, R.D. 8 (2.9), 47 (2.15), 51 (2.7); Souza, V.C. 5374 (2.25), 5375 (1.21), 5377 (2.17), 5392 (2.33), 5424 (1.21), 2280 (2.9), 22853 (2.35), 23048 (2.28), 23050 (1.21), 26213 (2.35); Souza-Silva, R.F. 190 
(2.9), 221 (2.28), 282 (1.21); Stannard, B. 5058 (1.21), H 51638 (2.35), H 51747, PCD 4865 (2.8), H 51782 (1.1), H 52113 (1.7), H 52705 (2.15); Stradmann, M.T.S. 1023 (2.15), 1114a (2.4); Teixeira, A.F.R. 20 (2.15); Teixeira, I. s.n. RB 73501 (2.10); Thomas, W.W. 9623 (2.5), 12715 (1.6), 12871 (2.15), 12887 (2.35), 12938 (2.4); Torrend, P.C. 297 (1.17); Tourinho, R. 34 (1.5); Travassos, O.P. 102 , 107 (2.22), 191 (1.14); Turma de Sistemática de Fanerógamas s.n. ALCB 58491 (2.38); Turma de Sistemática de Fanergamas 20002 (2.38); Ule, E. 7217 (2.37), 7302 (2.4), 7502 (2.40), 7504 (1.12), 7505 (1.20), 7512 (2.24), 7516 (1.5), 7517 (1.9); Valeriano, A. s.n. ALCB 2853 (2.22); van den Berg, C. 878 (2.10), 912 (2.38), 938 (2.31), 959 (2.10), 990 (1.23), 991 (1.14), 992 (2.28), 993 (2.28), 994 (1.14), 995 (1.17), 1161 (2.19), 1389 (2.8), 1398 (2.19), 1473 (2.8), 1474 (2.28), 1549 (1.7), 1550, 1871 (1.13), 1894 (1.1); Vidal, J. IV-793 (1.6), IV794 (2.10), IV-814 (2.7), IV-817 (1.6), IV-955 (1.14), IV-1039 (2.28); Vieira, R.F. 1129 (2.28); Violatti, L.G. 84 (1.21); Wanderley, M.G.L. 888 (2.25); Wanderley, P.H.S. 55 (2.19), 86 (2.28), 118 (2.19); Xavier, A.B. 18 (2.8), 201 (1.21), 288 (1.6); Yoshida-Arns, K. s.n. UFP 60334, s.n. UFP 60872 (1.4), s.n. UFP 61056 (2.19); Zehntner 99-990 (2.15), 115-963 (2.19). 